\title{
ARTICLE
}

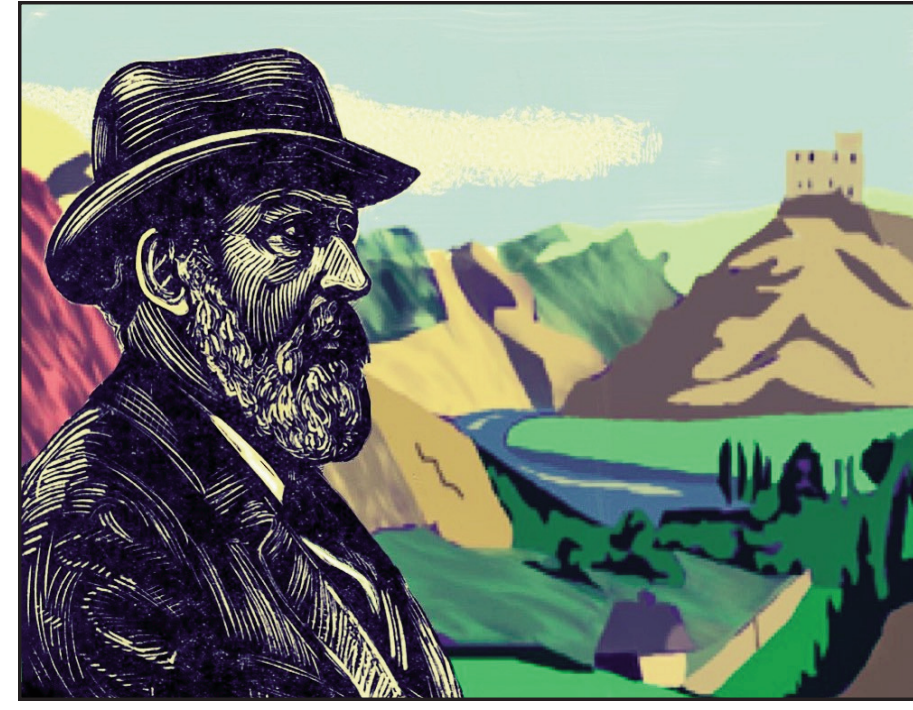

\section{The Founder of Modern Geology Died 100 Years Ago: The Scientific Work and Legacy of Eduard Suess}

\author{
A.M.C. Şengör \\ İTÜ Maden Fakülttesi \\ Jeoloji Bölümü ve Avrasya Yerbilimleri Enstitüsü \\ Ayazağa 34469 Istanbul, Turkey \\ E-mail:sengor@itu.edu.tr
}

\begin{abstract}
"Two things are to be remembered: that a man whose opinions and theories are worth studying may be presumed to have had some intelligence, but that no man is likely to bave arrived at complete and final truth on any subject whatever. When an intelligent man expresses a view which seems to us obviously absurd, we should not attempt to prove that it is somehow true, but we should try to understand how it ever came to seem true."
\end{abstract}

Bertrand Arthur William, 3rd Earl Russell (1945)

\section{SUMMARY}

Eduard Suess (1831-1914) is probably the greatest geologist who ever lived. He died 100 years ago and left us the modern geology as we know it. His work ranged from paleontology through stratigraphy, geomorphology, urban geology, finally to tectonics. His magnum opus was the multi-volume Das Antlitz der Erde (The Face of the Earth), the greatest book in the history of geology. It is a complete description of the geology of the planet from the viewpoint of the theory of thermal contrac- tion in Constant Prévost's version, as modified by Suess. For all the admiration it caused it has been largely left unread and as a consequence geology lost some half a century until the invention of plate tectonics in 1965. This was in part, because the way Suess wrote the book made reading very difficult. The following is not a biography of Suess, but a review and evaluation of his work during the centenary of his death.

\section{RÉSUMÉ}

Eduard Suess (1831-1914) est probablement le plus grand géologue qui ait jamais vécu. Il est mort il y a 100 ans et il nous a laissé la géologie moderne telle que nous la connaissons. Son œuvre va de la paléontologie à la stratigraphie, la géomorphologie, la géologie urbaine, enfin jusqu'à la tectonique. Son magnum opus est le multi-volume Das Antlitz der Erde (La Face de la Terre), le plus grand livre de l'histoire de la géologie. C'est une description complète de la géologie de la planète du point de vue de la théorie de la contraction thermique dans la version de Constant Prévost, modifiée par Suess lui -même. En dépit de l'admiration dont il était l'objet, ce grand livre a été très peu lu. En conséquence la géologie a perdu près d'un demi-siècle jusqu'à l'invention de la tectonique des plaques en 1965. C'est en partie a cause de la façon dont Suess a écrit le livre qui rend la lecture très difficile. Ce qui suit n'est pas une biographie de Suess, mais un examen et une évaluation de son travail à l'occasion du centenaire de sa mort.

\section{INTRODUCTION}

Eduard Suess (Fig. 1), the creator of modern geology and perhaps the greatest geologist who ever lived, died 100 years ago. Since then every geologist one time or another has dealt with or used his concepts and ideas, but many have not even heard of his name. This is because his work has become so much a part of what geologists do and encounter every day that citing his name has long been considered superfluous. This regrettably led to a collective amnesia among geologists that resulted in the fading of his name into oblivion. One might think that since we have learned what he wished to teach us so well, we no longer need to recall his work and remembering Suess ought to be the work of science historians. This, however, is emphatically not true. We, practicing geologists, have not yet learned everything he intended us to learn. We use his concepts and the terms attached to them, but frequently incorrectly, and we seem to have forgotten what made him so great so that we are unable to learn from the way he did geology. We do not realize that after the advent of plate tectonics geology in many ways returned to Suess' way of looking at the earth and abandoned what had been done since his death, and since about 1980 we seem to have abandoned his guidance again. Consequently, in our amnesia, we have reinvented a number of 


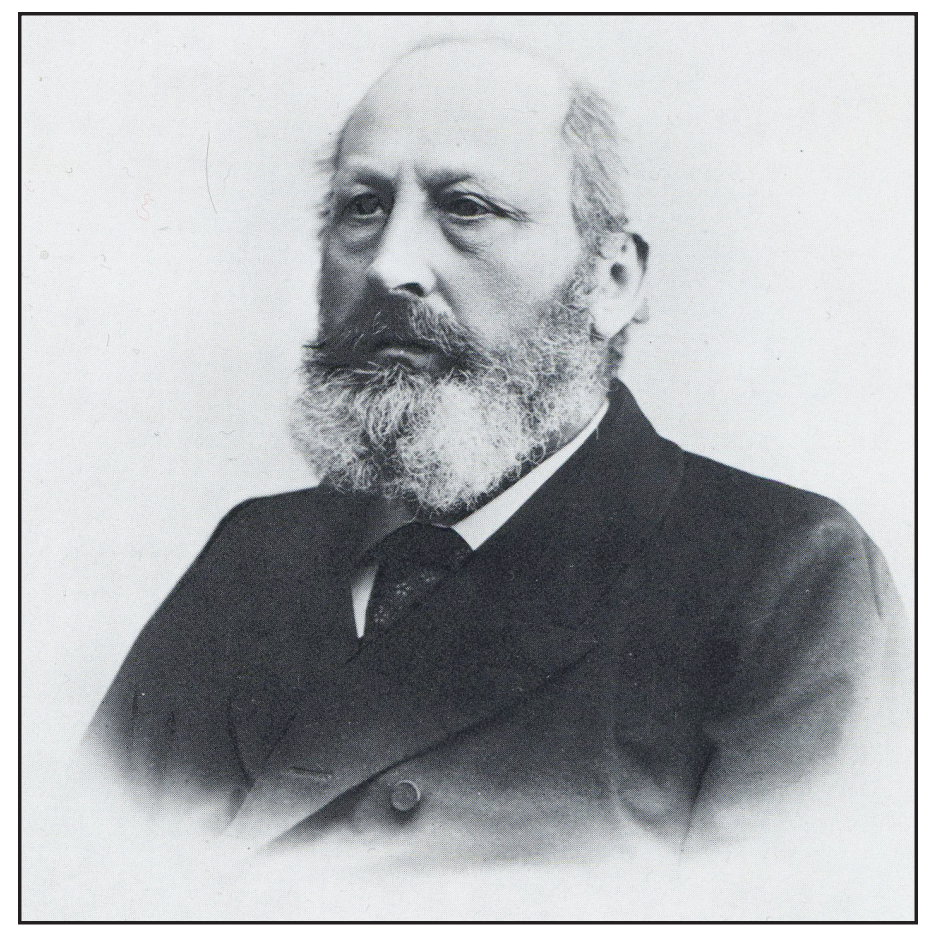

Figure 1. Eduard Suess.

the retrogressive ideas or ways of looking at geology of some of his later inferior critics, leading to frustrating impasses.

I pointed out elsewhere that between 1924, when the great Swiss geologist Émile Argand (1879-1940) essentially withdrew from geology and 1965, when the brilliant Canadian geologist J. Tuzo Wilson (1908-1993) invented plate tectonics, there was a retrogression in tectonic studies in general in the entire world. I called this interlude "The Dark Intermezzo" (Şengör 1998). The progenitors of this intellectual lull in tectonics were essentially Aristotelian in their approach to science. As the great South African geologist Alexander Logie Du Toit (1878-1948) once said, they thought geological objects were where they were, simply because they were there. They equated naming and classifying with understanding. They adopted or adapted from others or by themselves created holistic models and tried to force the available observations into these models. They frequently claimed to have been testing their models, but every time a model failed, they added ad hoc bits to make it escape falsification. Strangely, these scientists were positivists in the sense that they made observations to 'confirm' their models, rather than trying to falsify them, because they believed 'induction', i.e. accumulation of observations, would finally 'confirm' hypotheses. They lived under the delusion that their models were 'natural outgrowths' of their observations and thus sacrosanct. They imposed on Nature all sorts of 'regularities' and believed them to be the true properties of the planet. This way of thinking made them hostile to Hutton's actualism and some among them called themselves 'neo-catastrophists'. This was because some of their holistic models did not fit what we see to be going on in the geological world today, and thus it was thought that the past had to have been different from today.

Eduard Suess did geology differently. He too erected models, but he truly tested them as mercilessly as he could and abandoned many in the process. He never believed that any model could be confirmed by induction, but only corroborated temporarily. In a public lecture he gave in 1890, he pointed out that:

"The natural scientist must know that his work is nothing else but climbing from one error to another, but, with the realization that getting closer and closer to the truth, similar to one who climbs from crag to crag and, even if he does not reach the summit, he sees the landscape open up before his eyes in ever more majestic sceneries." (Suess 1890, p. 4).

This made him what his great countryman Karl Raimund Popper (1902-1994) would later call a critical rationalist. Throughout his professional life Suess remained an actualist and never trusted the so-called regularities claimed to have been discovered in geological processes; perhaps he remembered that the first of Francis Bacon's (1561-1626) 'idols', i.e. bad habits of mind leading scientists to error, prominently included the unwarranted assumption that Nature is more orderly than it really is (Bacon $1620\{1863\}$, p. 253-254). Suess rather saw a much more chaotic evolution of the earth. In his first major book that made a great impact in the world of geology, he wrote:

"In what a wonderful manner Nature refutes our assumptions! ... After we have given up a geometric system and accepted the one-sidedness of the movement, we find a dominant uniform northward striving in many mountain ranges, considered old or young, from the Cordillera to the Caucasus. We would like to formulate a law of flow of the upper part of the earth towards the pole. But this is also wrong. Farther to the east follow some dislocations along the meridians, then the moving force turns south in the mighty high mountain ranges of inner Asia. We thus obtain a picture of the face of the earth which does not at all correspond to our expectations of regular beauty, but so much more to the truth." (Suess 1875, p. 145-146).

Sixteen years later, in his famous paper announcing the true nature of the Great Rift Valleys of East Africa, Suess emphasized again:

"In the descriptions of this kind we have to avoid assuming geometrical arrangements of any sort, and, in the face of the unmanageable variety of the occurrences, a methodical search for regularities is not without danger, because the searching mind is too easily diverted for the sake of a healthy synthesis. Where something like a symmetric arrangement on a large scale is really present, as in the northern parts of the Atlantic Ocean, such an arrangement appears before our eyes by itself and without enforcement. It is instructive to see how, in defiance of any geometric arrangement, this immense chasm [i.e. the East African Rift valley], after having traversed so many degrees of latitude from Nyasa northwards, meets the boundary arc not at a syntaxial angle, but at a point that to us looks entirely random. Step by step the picture of the planet is perfected and it deviates ever farther from those ideas that we entertained a few decades ago." (Suess 1891, p. 584; addition between square brackets is mine).

He had spent a good deal of his life trying to understand what he in 1888 had called eustatic movements. In 1911, just three years before his death, he wrote to his American correspondent, the famous Yale geologist Charles Schuchert (18581942), in a letter expressing his gratitude for the present of an offprint of Schuchert's 1909 paper entitled Paleogeograpby of 
North America (Schuchert 1909), the following (Schuchert considered the contents of this letter so important that he published it in the American Journal of Science, of which he was then the editor):

When I wrote of eustatic movements in 1883 [he had done so without yet naming them], I confessed that I did not understand the transgressions. I thought that variations in rotation might somehow have influence. I also believed and still think that the accumulation of sediment was a vera causa, but hardly sufficient. Now, after twenty-seven years, I cannot offer you more than a beap of doubts regarding the explanation. I have learnt more and know less about it. (Suess 1911a, p. 107; addition between square brackets is mine).

Who was this man Eduard Suess? Where did he get this confidence in himself to fearlessly declare his own ideas wrong and admit to ignorance after a lifetime of hard work which was universally admired? When he was alive he was considered the dean of geologists the world over; during the 1897 International Geological Congress in St. Petersburg, the members of the congress came together, under the leadership of the great Russian geologist Alexander Petrovich Karpinsky (1847-1936), and sent Suess a telegram to congratulate him on his birthday; when the foremost German geologists assembled in 1910 in Frankfurt-am-Main in Germany to found the Geologische Vereinigung, they asked Suess in Vienna to accept the honorary presidency of the new international society, to which he graciously agreed. Then, three distinguished members of the first meeting, Gustav Steinmann (1856-1929), Wilhelm SalomonCalvi (1868-1941) and Otto Wilckens (1876-1943), read papers on three different chapters of the last volume of Suess' magnum opus, Das Antlitz der Erde, published the previous year (Salomon 1910; Steinmann 1910; Wilckens 1910); the totality of that unique book had at the time already been translated into English and a French translation by the most eminent geologists of France was under way; later a Spanish edition also appeared, again under a distinguished aegis.

Who was indeed this extraordinary man, who had also become a politician with the sincere desire of putting his scientific knowledge at the disposal of his countrymen and who would always turn down any state accolade or decoration, universally coveted by others, and accept only the recognition of scientific bodies? In his testament he wrote the following words, sufficient to qualify him as a 'super-human' in Nietzsche's definition:

"It has been my lot to have a long life fairly free of physical suffering. In old age I possess the highest joy of having a tranquil conscience and an innerly cheerful spirit. I shall die following an eternal natural law and there is no reason to grieve my death. I wish to leave behind grateful memories, not sad ones." (Vienna, 11 ${ }^{\text {th }}$ November 1912; Dr.-Ing. Wolfgang Gasche, great-grandchild of Eduard Suess, written communication, $23^{\text {rd July } 2014) .}$

Where did he come from? What drove him? And, what is it that he bequeathed to us that we first entirely forgot, for more than half a century, and then rediscovered; only overlooking the fact that it was his legacy that we had rediscovered. That is why, I am afraid, we are back on the way to abandoning his way of doing geology.

\section{Birth, Family and First Steps in Geology}

Eduard Carl Adolph Suess was born in London on 20th August 1831 during a prolonged residence of his parents in the British capital. He was born to an Austrian merchant family and his mother was the daughter of the wealthy Zdekauer banking family in Prague. The Zdekauers were of Jewish origin, but they had converted to Lutheranism before Eduard was born. His father Adolph's family was originally from the mining kingdom of Saxony and Lutheran. Adolph Suess had in fact studied theology obtaining a candidatus theologia degree, but Eleanore's father had made it a condition to permit the marriage that the young bridegroom find a suitable occupation to be able to feed his family in a manner Eleanore had grown accustomed to. When Suess was only three years old the family moved back to Prague where he went to school. They had brought back from England an English nurse, who in due course was replaced by a house preceptor to make sure that the children did not forget their English. Soon thereafter a French and a German instructor were added to the home faculty and Suess thus grew up trilingual. Rudolf Hundt, in his memorial to Suess (Hundt 1917), mentions a mademoiselle as the first French teacher, but Suess makes no mention of this in his memoirs (Suess 1916). The French teacher who is mentioned was a Belgian, a veteran of Napoléon's Grande Armée and delighted young Eduard with his stories of the Russian campaign. By contrast, the German teacher proved to be a stickler for grammatical minutiae. His teaching imparted on Suess a life-long dislike of rigid rules.

During the last year of his high school, in 1846, the family moved to the imperial capital to take over the leather factory of an ailing uncle. Suess finished high school (which he did not much like) and, following the advice of his father, entered the Vienna Polytechnical Institute (the present Technical University of Vienna) with a view to obtaining an education that would enable him to continue the family business. He enjoyed the courses because he found them stimulating. While attending the Institute, the March 1848 events broke out and Suess found himself on the side of the revolting population as a member of the Academic Legion. He stood sentry in front of a bank, rifle in hand, and played not an insignificant role in the discussions of the committee that ran the Legion. Finally, the revolution failed (although the despotic Klemens Wenzel Prince of Metternich (1773-1859) had fled the capital) and Suess' prudent father, expecting the worst, sent his son back to Prague to his grandparents' house ostensibly for recuperation because of an infected foot.

It is really in Prague that our geological story begins. The Fatherland Museum in Prague (Fig. 2; the present Národni Muzeum at the Wenceslas Square; the Square had just changed its name from Rossmarkt in 1848; but when Suess visited the Museum it was still housed in the Nostic Palace, on the Maltézské Náměstí \{Maltese Square\}) had been founded in 1818 by a number of prominent Bohemian noblemen, among them the great paleobotanist Kašpar Maria Count of Šternberg (1761-1838) using the money left over from the aid campaign to starving peasants because of the 'year without a summer' that had resulted from the 1815 eruption of Tambora on the island of Sumbawa in Indonesia causing widespread crop failure in the northern hemisphere. During a visit, Suess saw the early Paleozoic fossils collected from the classical Barran- 


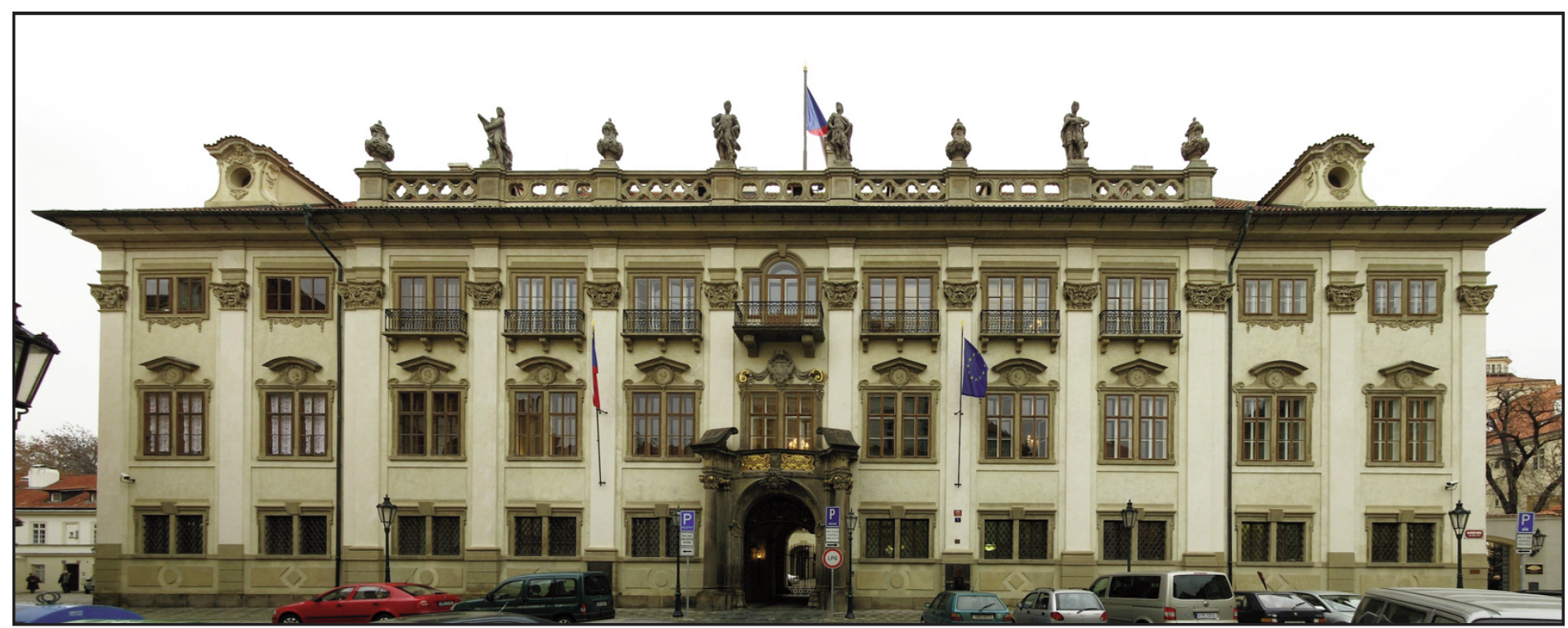

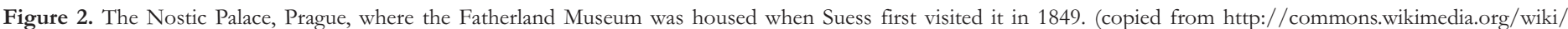
File:Nosticky_palac.jpg)

dian around Prague and fell in love with them. In his memoirs he reminisced:

"The sight of a long extinct marine population, the thought of the immense changes that the country had experienced and the realization that a strike of my hammer might expose an image that nobody before me had seen gripped my fantasy to such an extent that it was impossible to keep my attention on any other study. As soon as my foot recovered, I spent every free day at some rich fossil locality near Prague ..." (Suess 1916, p. 71-72).

A liver trouble necessitated a visit to the thermal springs of Karlsbad west of Prague (now Karlovy Vary in the Czech Republic) and there Suess investigated the geology of the surroundings of this famous spa town. A publisher, about to publish a tourist guide to the town and its surroundings, noticed his interest and approached him to ask whether he would be prepared to write a few pages on the 'geognosy' of the area. Suess agreed and the little booklet appeared in 1851 (Anonymous 1851). It is impossible to read the few pages Suess wrote without admiring the 18-year-old's knowledge of the geological literature of the area. One wonders where he found the time to find and read all the publications he cited. After all, it had not yet been a year since his interest in geology had been awakened.

Those few pages on Karlsbad and surroundings show that two prominent characteristics of Suess' way of doing geology had been with him right from the beginning: a careful study of the rocks and a thorough knowledge of the relevant literature. Could he have learnt these from the remarkable curator in the Museum, Maxmilián 'Max' Dormitzer (born into a prominent Jewish family sometime between 1819 and 1823 and died, very early, in 1853), who was essentially a zoologist (but also responsible for paleontology),

"a sociable, educated man, an ardent naturalist, speaking several languages and interested in different topics of biosciences ... a skilful draughtsman" (Hlustik 1990),

who took Suess along on excursions and allowed him to open the drawers of fossils and who was the first natural scientist with whom Suess had any close contact? Even if Dormitzer did not teach Suess everything, he must have been a formidable role model for him. In any case, it is clear that Suess had grasped the essence of geology very early: the more one knows about rocks in all their aspects, the better one would understand them; yet the areas to be studied (eventually the whole planet) are so vast that one would have to rely on the observations of others also; thus one had to read a lot. This led to the development of a critical-judgmental (to be judgmental is a positive attribute!) method of using the literature that consisted of comparing various accounts of a region with one another and with other reports on surrounding areas. As J. Walter Gregory (1864-1932) of the Great Rift Valley fame once remarked, this method allowed Suess to come to better interpretations of the geology of various areas he had never seen than the people who were in the field and on whose writings Suess had based his interpretations.

In Prague Suess began undertaking his own excursions to the surroundings during which he developed an interest in and some original ideas on graptolites. He worked his results into a paper but was then told that the great French refugee paleontologist Joachim Barrande (1799-1883; he had fled with the royal family during the 1830 revolution in France) was working in the area. Suess dutifully submitted his samples and paper to Barrande for his criticism. Barrande refused and instead rushed to print a small book that covered many of the same species (Barrande 1850). Suess was heartbroken by this ungentlemanly behaviour but did not allow this episode to cloud his relationships with Barrande. He even obtained the elder man's friendship eventually. This is a third characteristic of Suess that we shall encounter time and again in his life: he never permitted a person's character to colour his view of his scientific merit. For example, in his memoirs he wrote the following about the great French geologist Élie de Beaumont:

"I introduced myself to the great geologist Mr. Élie de Beaumont, who received me with a condescending attitude and the allure of a superior being. Despite this childish behaviour I have never ceased to respect him because of his deep knowl- 


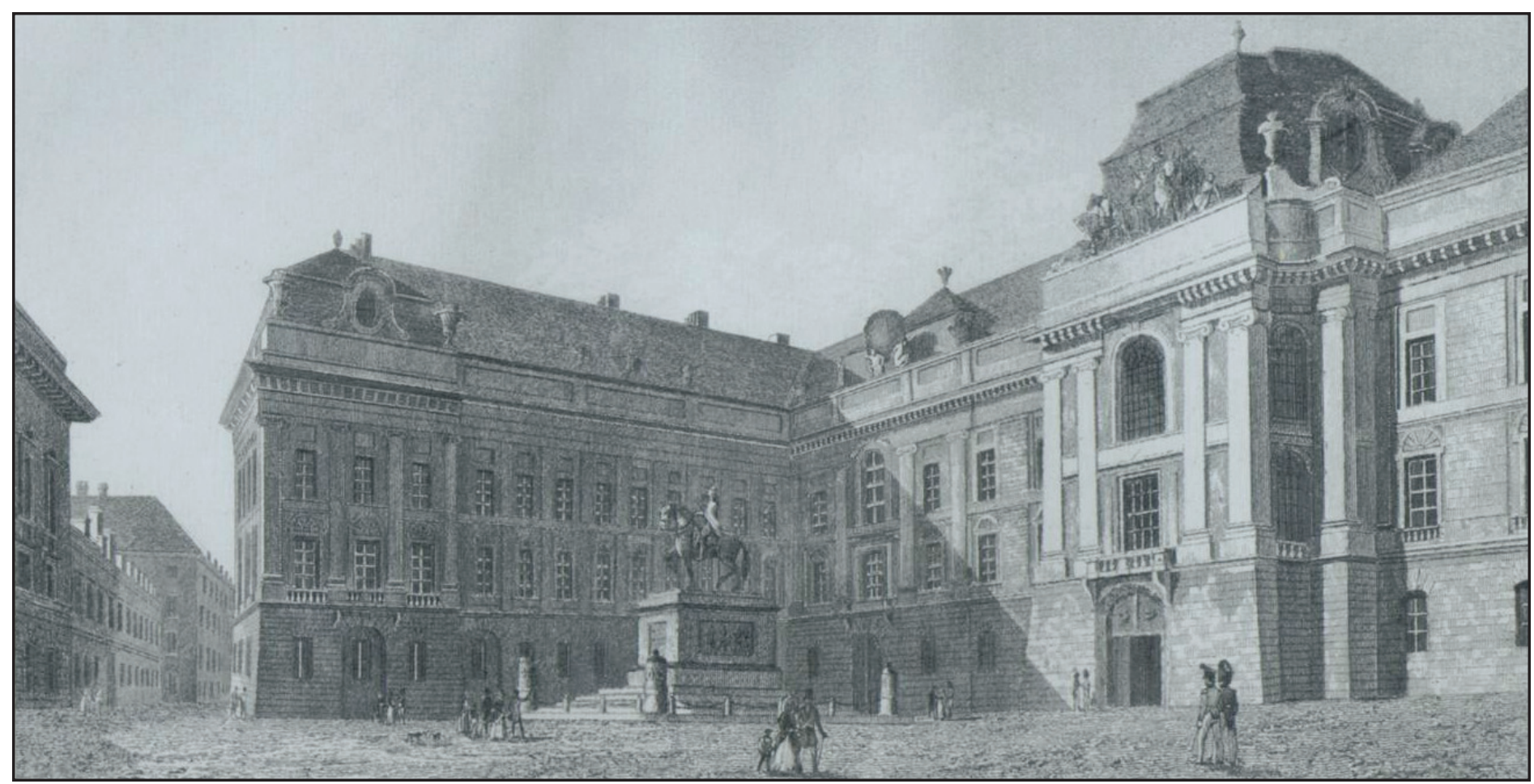

Figure 3. The view of the Hofburg in Josefsplatz, Vienna. The left top floor housed the Hofmineralienkabinett when Suess was employed there.

edge and his constant attempt at a global view" (Suess 1916, p. 127).

Despite Barrande, Suess' paper appeared (Suess 1851) in a journal published by the most eminent earth scientist of Austria in those days, namely the great mineralogist Wilhelm Ritter von Haidinger (1795-1871). The Emperor had just established the Geological Survey of Austria (Geologische Reichsanstalt, founded in 1849) and Haidinger was at its head. In this paper one sees Suess' broad knowledge of paleozoology and its methods. He minutely studied his graptolites using a microscope and discovered many new aspects of these tiny creatures that had escaped the hasty Barrande, but he conscientiously followed Barrande's taxonomy established in the booklet he had rushed to print to scoop Suess.

In the meantime, in Vienna his father's fears had come true and Suess was summoned to the police in 1850 . He ended up in prison for his role in the 1848 revolution, but was finally able to prove that he had done nothing that could constitute a crime and was released only a month later. However, this painful experience made him realize that he could no longer continue his studies in the Polytechnical Institute. He had been branded too visibly as a political figure.

This probably appeared to Suess as a godsend. He remarked in his memoirs:

"As I had sensed the emptiness of the high schools as a child, I felt with greater pain that engineering was simply a study to earn a living and that even the much praised mathematics served to sharpen the intellect and the memory, but left everything else cold. I therefore felt the urge ever more to turn towards a science." (Suess 1916, p. 73).

As a result Suess decided to leave the Institute and to become first a volunteer, then, a year later (on 10th May 1852), a salaried assistant, in the Hofmineralienkabinett, the ancestor of the present magnificent Natural History Museum in Vienna, at the time headed by the venerable Austrian geologist Paul Maria Partsch (1791-1856).

\section{Suess' Activity in the Hofmineralienkabinett: Beginning International Recognition and Marriage}

When he entered the service of the Hofmineralienkabinett (Fig. 3) Suess' first task was to organize the brachiopod collection and to help with the upkeep of the library. Suess considered his job at the Hofmineralienkabinett as his first geological schooling. He later remarked:

\section{"As part of this schooling I also consider the commonly tiring mechanical work. The updating of the catalogues of the library and the collections continuously have impressed on my memory literature, titles and names, the knowledge of which later turned out to be of the greatest advantage." (Suess 1916, S. 146).}

He seems to have started with the genus Terebratula. I am not aware whether he was asked to do so or he chose this genus himself, but the remarkable thing about the Terebratula (named by the Danish naturalist Otto Friedrich Müller \{1730$1784\}$ in Müller 1776, p. 249, items 3006-3008) is that it is a modern and widespread genus with its close ancestors dating back to the late Devonian. It is thus easy to compare its past relatives almost throughout the entire Phanerozoic with the present representatives. It may be coincidental with respect to his first official duty, but Suess remained keen all his life to find present-day examples and/or analogues of the objects and processes, the records of which he discovered in the past. Years later, in 1859 and 1860 he published an important paper in two parts dealing with the ecology of brachiopods in which he started with the ecology of the extant ones (Suess 1859, 1860a).

His initial work was taxonomic, and among the brachiopods classed as Terebratula, he rapidly discovered two 
groups that deserved their own genera. Already as a volunteer, he had identified the genus Merista, followed four years later by Meganteris. Both of these genera are still valid. He also published on the paleozoology of the Thecidaea Keferstein 1829 and the Terebratuloid Stringocephalus burtini Defrance 1825 (in de Blainville 1825, 1827), describing its brachial apparatus. This last paper was translated into French and also published in France.

By 1855 Suess had published some 10 papers, almost all on paleontology, but these few publications were considered to be of such importance that his name was already famous both in France and England. The paleontologists who asked for a translation of his brachial apparatus paper called him, in a footnote, 'a young and very distinguished paleontologist' (Suess 1855, p. 1) and the great German paleontologist Albert Oppel (1831-1865) reported to his friend Friedrich Rolle (1827-1887) in Vienna in a letter he wrote on 23rd July 1855 that

"your Mons. Suess must be a very famous man, because in France and England I heard about him more than about any other German scholar" (Martin 1961, p. 141).

While Suess was a volunteer in the Hofmineralienkabinett, he also volunteered as a mapping geologist in the Geological Survey. In the same year he was detailed as an assistant to Franz von Hauer (1822-1899), 'the second geologist' of the Survey, who had the duty to map a cross-section across the Alps from Passau in the north to Duino in the south. Suess asked for the highest part of the geotraverse and mapped the gorgeous Dachstein Massif in the Northern Calcareous Alps (Suess 1857). There he collected many fossils, but published the brachiopods of the Kössen Beds in a separate memoir (Suess 1854). This is important, because the paleontology of the Kössen Beds were to hand him two years later the keys to the correlation of the Alpine Mesozoic sequences with those of their foreland, drawing the attention of a geologist no less than Sir Charles Lyell (1797-1875) to his work (Şengör in press).

During the same field campaign Suess noticed something else. Within the Mesozoic sedimentary rocks, all the way from the Triassic to the Cretaceous, there were unmistakable rounded clasts of the metamorphic rocks underlying them. Now this was a shock, because, at the time, all mountain-building theories held that the central crystalline massifs had intruded the overlying sedimentary rocks, deforming, metamorphosing and uplifting them. If the eroded clasts of the same metamorphic rocks were found in the overlying sedimentary rocks, the metamorphic rocks had to be older (the discovery of mantled gneiss domes by the great Finnish petrologist Pentti Eelis Eskola $\{1883-1964\}$ in 1948 was still almost a century in the future). Suess also noticed that the metamorphic rocks and the sedimentary rocks were deformed together. These observations did not sit well with the current ideas on how to make the Alps. Suess did not say anything at the time, but he was troubled. So troubled in fact, that eight years later, after he had become a professor, he took two of his prize students, Ferdinand Stoliczka (1838-1874) and Edmund Mojsisovics Edler von Mojsvar (1839-1907) and returned to the locality and published a note concerning his now corroborated observations (Suess 1860b).

In 1854, he went to a meeting in Switzerland and met the great Swiss geologists Peter Merian (1795-1883), Bernhard
Studer (1794-1887) and Arnold Escher von der Linth (18071872). Merian and Escher were so impressed by this young man that they accompanied him on his way back home as far as Innsbruck and on the way Escher showed him the imbricate folds of the Säntis and the (then) weird phenomenon of Permian overlying the Eocene across a sharp and subhorizontal contact for kilometres in the Canton of Glarus. Escher thought this was a result of two recumbent folds facing each other, the so-called 'Glarus noose'. Suess was puzzled, but became nevertheless impressed with the mobility seen in mountain belts. Years later, in 1884, he was the first to endorse Marcel Bertrand's (1847-1907) reinterpretation of Escher's double fold as a single north-vergent nappe (Diener 1914, p. 19; Hilber 1915, p. 6).

In late April to early June 1856, the Hofmineralienkabinett sent Suess on a research tour to investigate the reported similarities between the Jurassic formations of Bohemia and northwestern France and to collect or, wherever necessary, to buy fossils. During this tour he examined various European localities of fossils belonging to different ages, bought some for the museum and collected some while familiarizing himself with a considerable portion of the geology of continental Europe first-hand. In Paris he met the great paleontologist Gérard Paul Deshayes (1795-1875) and the geologist Élie de Beaumont (1798-1874). Deshayes may have told him during their meeting that he did not believe mountain-building events episodically exterminated the fauna and flora of the earth. Suess agreed with Deshayes and cited this view approvingly years later (but referencing only the more emphatic statement of Étienne Jules Adolphe Desmier de Saint-Simon, Viscount d'Archiac (1802-1868); Suess 1883, p. 11).

$\mathrm{He}$ arrived in Stuttgart and visited Albert Oppel (18311865), who, at the time, was working on his great Jurassic book (Oppel 1858). Oppel showed him his fossils gathered from around Stuttgart and therein was the bivalve Avicula contorta Portlock 1843 (now revised as Rhaetavicula contorta (Portl.)). Suess at once grasped that here was the exact equivalent of the Kössen Beds in the Alps, which, at the time, he considered to be basal Liassic. This was the first time that it became possible to correlate the Alpine Mesozoic sedimentary sequences with those outside the Alps. This was extraordinary: the Triassic/Liassic boundary beds known for a long time from County Antrim in Ireland, from Normandy, from the Mont d'Or of Lyon and from Swabia had found their correlatives in the Alps thus removing one of the major problems of the mid-19th century stratigraphic geology, namely the correlation of the littoral to neritic thin and lacunar Mesozoic foreland sequences and the neritic to pelagic Alpine sequences of immense thickness. Suess and Oppel wrote a paper which was presented to the Academy of Sciences in Vienna on 24th July 1856 (Oppel and Suess 1856). Von Zittel pointed out in his classic history of geology and paleontology (von Zittel 1899, p. 630) that until that time, of the thousand marine species of fossils described from the Triassic of the Alps, not one had been found to be common to the foreland sequences. That is why von Zittel called the paper by Oppel and Suess 'epochmaking.'

Suess also read a paper on the same subject to the meeting of the German Geological Society in Vienna on 20 ${ }^{\text {th }}$ September 1856 and, as luck would have it, Sir Charles Lyell happened 
to be in Vienna between the two papers Suess read. Surprisingly, he did not hear of the great new discovery in Vienna. He found out about it, at the latest in October of 1856, when he visited the great German geologist and Oppel's teacher Friedrich August von Quenstedt (1809-1889) in Tübingen. In any case, Lyell wrote a letter to Suess as soon as he learned about the discovery and asked him to send him a summary of it with a view to including it in a supplement to the fifth edition of his Manual of Elements of Geology. Suess obliged and his summary duly appeared in the supplement (Lyell 1857).

The reason why Lyell was so excited was that until that time the top Permian and the Triassic deposits in extra-Alpine Europe had appeared to be very poor in fossils and that it seemed as if something dreadful had happened during the Permian to cause such a drastic diminution of life on earth. Sir Charles did not like this, because it ran counter to his uniformitarian ideas. The discovery of thick Triassic deposits teeming with life made him sigh with relief and he said as much in his Supplement.

Shortly after he had joined the Hofmineralienkabinett Suess had fallen in love with the niece of the director, Hermine Anna Strauss (1835-1898; Fig. 4), as a result of a chance meeting and had married her. Eduard and Hermine had a happy life together until 1898 when Hermine Suess passed away. They had six children, one of which became a great geologist himself, the last of the Viennese Giants: Franz Eduard Suess (1867-1941) whose son, Hans Eduard Suess (1909-1993), became a worldrenowned cosmochemist.

\section{Professorship}

While all these exciting things were going on Suess became very distressed about the state of geological teaching in the Austrian Empire. Geological material was taught as isolated statements of fact about rocks and minerals which the students found extremely dull. He thought he could do better and applied, armed with offprints of his papers and letters of recommendation from the foremost geologists of Austria, namely Wilhelm Ritter von Haidinger (the head of the Survey), Franz Ritter von Hauer (the second geologist of the Survey), August Emanuel Rudolph von Reuss (1811-1873; professor of mineralogy in Prague) and Moritz Hoernes (1815-1868; head of the Hofmineralienkabinett after the death of Partsch in 1856) to the University of Vienna with the intention of obtaining a teaching position as a Privatdozent (unsalaried associate professor). The faculty laughed him off as he did not even possess a university degree, let alone a doctorate, the minimum requirement for a teaching post. Any lesser soul might have stopped there, but not Suess: he took his documents, wrote a letter to the Minister of Culture and Education responsible for the universities, and obtained an audience. He was fortunate, because the minister Count Leo of Thun and Hohenstein (1811-1888; Fig. 5) was a man of unusual calibre and learning. The Minister told Suess that the law indeed forbade him to make Suess a Privatdozent, but, he added, he could find nothing in the law to prevent him from appointing Suess a professor! So, to the scandal of the University faculty, Suess was appointed an unsalaried (because he was still drawing a salary from the Hofmineralienkabinett) professor of paleontology, the first of its kind in the entire monarchy, on 24th July 1857 and His Apostolic Majesty approved the appointment on 10th August 1857.

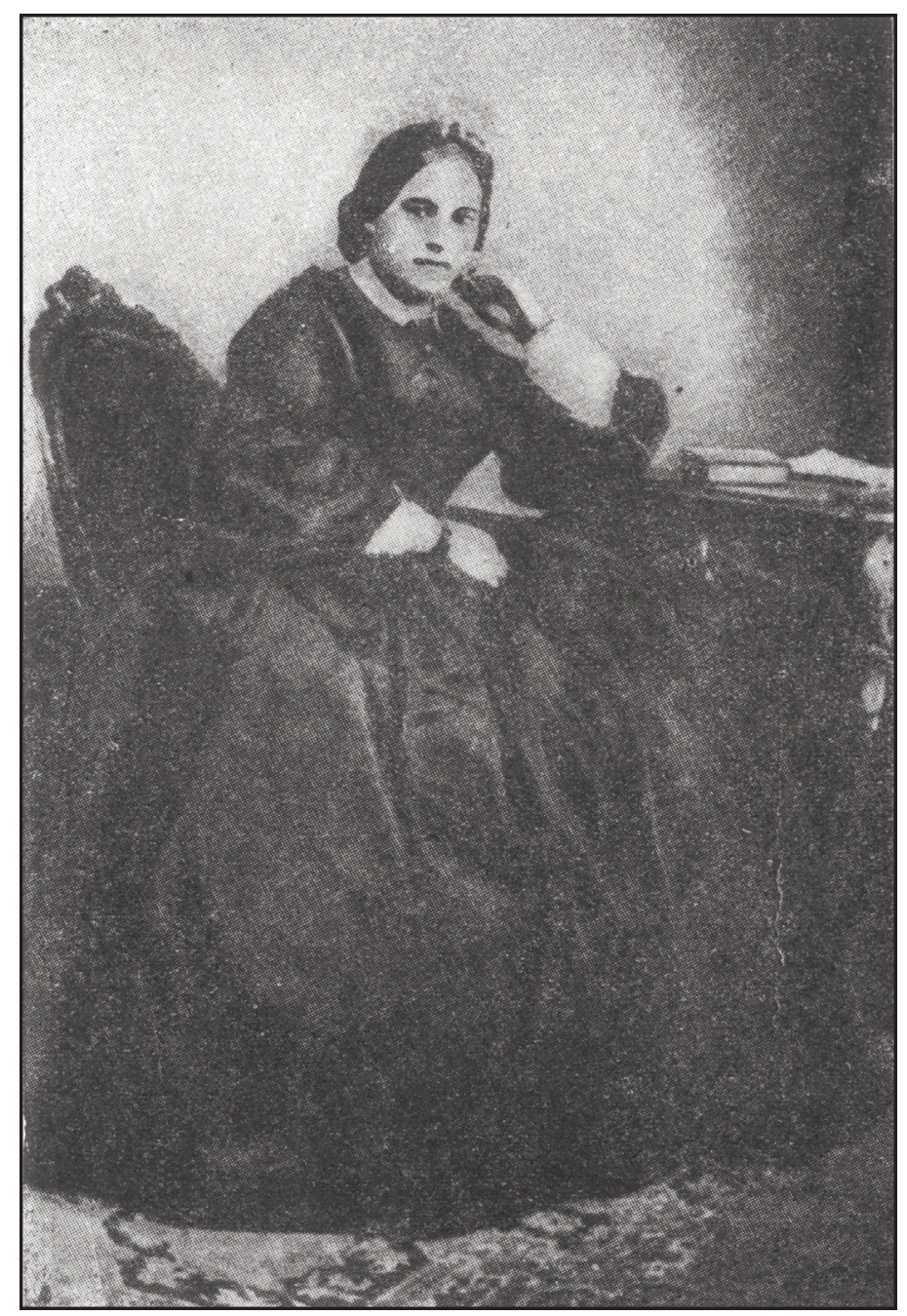

Figure 4. Hermine Anna Suess (from Obruchev and Zotina 1937).

Suess had also obtained permission to hold his classes in the Hofmineralienkabinett to be able to use its rich collections as teaching aids.

Thus, by 1857, Eduard Suess had become a famous paleontologist in the world and a respected citizen in Vienna. But the world did not as yet know what this 26-year old professor was about to do with his subject — both for the world at large and for his own country.

\section{Suess' Stratigraphic Studies and the Beginning of his Interest in Global Tectonics}

Teaching took Suess out to nearby areas for field trips for his students (never more than a handful) in and around Vienna and this inevitably led to an interest in the Cainozoic deposits of this young basin. In the winter of 1858, he was invited to give a talk in the building of the Academy of Sciences, in the framework of the newly established 'Monday Lectures' concerning the recent developments in the natural sciences, on the topic of the geology of Vienna with special regard to the artesian wells in the city. It was these lectures that prompted him to start a book on the geology of Vienna in the winter of 1859/1860. Later, in 1861, the Society of Physicians in Vienna invited him to talk about the sanitary conditions of the water in Vienna. During the preparations for these lectures Suess noticed that the imperial capital drew its water from aquifers 


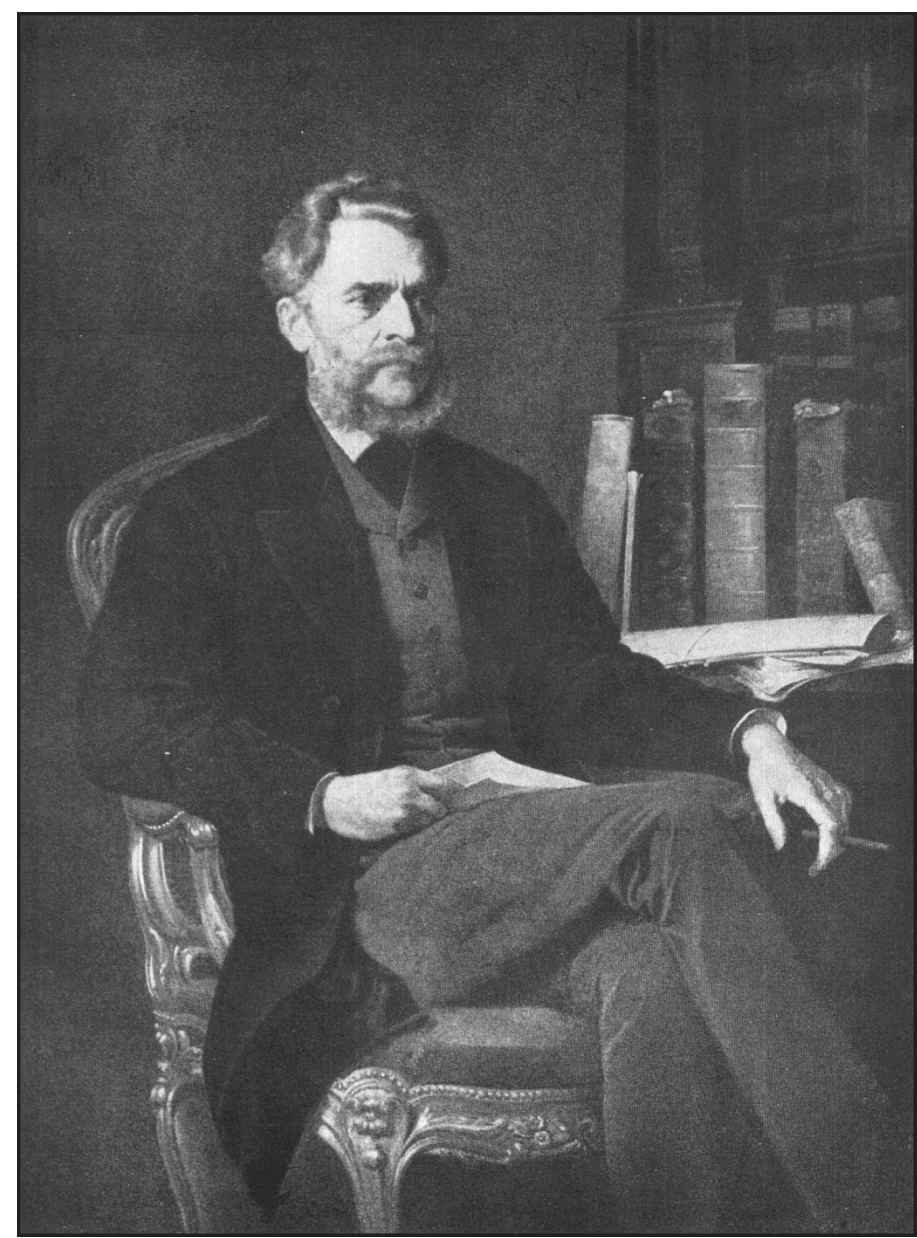

Figure 5. Count Leo von Thun-Hohenstein, the great minister of Culture and Education of the Austrian Empire, who single-handedly made a present of Suess to the scientific world.

consisting of young gravels mostly on the surface. He mapped out the death cases during the most recent typhoid fever epidemic - a frequent and very deadly occurrence in Vienna at the time-and concluded that the water in the wells was the culprit, much like the earlier Broad Street pump cholera outbreak in London (cf. Hempel 2007). He showed that the water circulated through the high-lying cemeteries around the city before coming into the wells. Every time a typhoid victim was buried, the corpse infected the water and the people living downstream became the next victims. He wrote his first book in 1862 entitled Der Boden der Stadt Wien nach seiner Bildungsweise, Beschaffenheit und seinen Beziehungen zum Bürgerlichen Leben ('The ground of the city of Vienna, its structure, characteristics and in its relation to citizens' life'), after having abandoned his earlier manuscript, and in it published his results. He also outlined in the same book the entire geology of the Vienna Basin and showed that it contained a sedimentary fill consisting of three packages of rocks: at the bottom, a marine sequence (now considered a part of the Badenian in the Paratethyan chronostratigraphic scheme: Middle Miocene), a paralic sequence (now considered normal marine Sarmatian in the Paratethyan chronostratigraphic scheme \{Piller and Harzhauser 2005\}: also Middle Miocene) and a freshwater sequence (now its limnic sections are considered a part of Pannonian in the Paratethyan chronostratigraphic scheme: late Miocene, and its fluvial deposits are a part of the Quaternary). Suess in his 1862 book considered this evolution a consequence of an episodic uplift of the entire European continent, in line with Lyell's views.

The little book attracted widespread attention and Suess was elected to the town council in 1863. This was the beginning of his three-decade-long political activity. In the council, he pointed out that under the existing conditions healthy drinking water could not be supplied to the city. When asked what to do about it, he argued that clean water had to be brought in from the Alps about $110 \mathrm{~km}$ away by means of aqueducts. The elderly and conservative mayor Andreas Zelinka (1802-1868) listened to his suggestion and replied: 'Suess, you are insane!' Fortunately for Vienna, Zelinka died in 1868 and his vicemayor, Cajetan Felder (1814-1894), a brilliant, energetic man and a friend of Suess, became mayor (cf. Felder 1964). Then, the two began earnestly considering Suess' idea and concluded that the Kaiserbrunnen ('Emperor's Spring') in the Schneeberg, a karstic spring in the Northern Calcareous Alps near the southwestern termination of the Vienna Basin, was the most suitable candidate for the water source for the city. The spring belonged to the imperial family, but the Emperor Franz Joseph I (1830-1916) was easily persuaded to give it to the people of Vienna as a present (on 30 ${ }^{\text {th }}$ April 1865: Fig. 6). The immense engineering project took some five years to complete (Fig. 6c) and was inagurated on 24th October 1873 with a splendid ceremony, during which Suess was asked to turn the valve to let the first waters of the system to enter the city. The Emperor personally thanked him. A week earlier, on $17^{\text {th }}$ October, he had been made an honorary citizen of Vienna for his service. Suess had deserved it: after Alpine water had come into the city, the typhoid epidemics vanished and today the citizens of Vienna still drink Suess' water, considered to be the best among the waters of all the European capitals (see p. 315-324 in Felder 1964; "Suess'-Wasser" is even cited by the prison director Frank in Johann Strauss' operetta Die Fledermaus \{The Bat\} that premiered only five months after the inauguration of the water works on the 5th April 1874!). The idea proved to be so good in Vienna that a second aqueduct system was built during the first decade of the twentieth century.

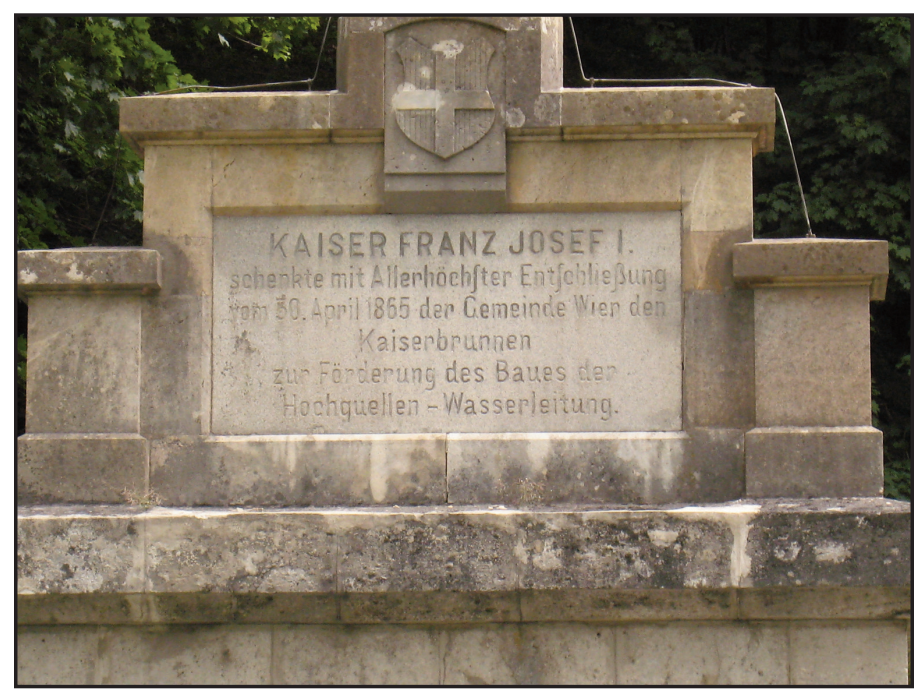

Figure 6a. Inscription atop the Waterlock of the Hochquelle (high spring) at Kaiserbrunnen. 


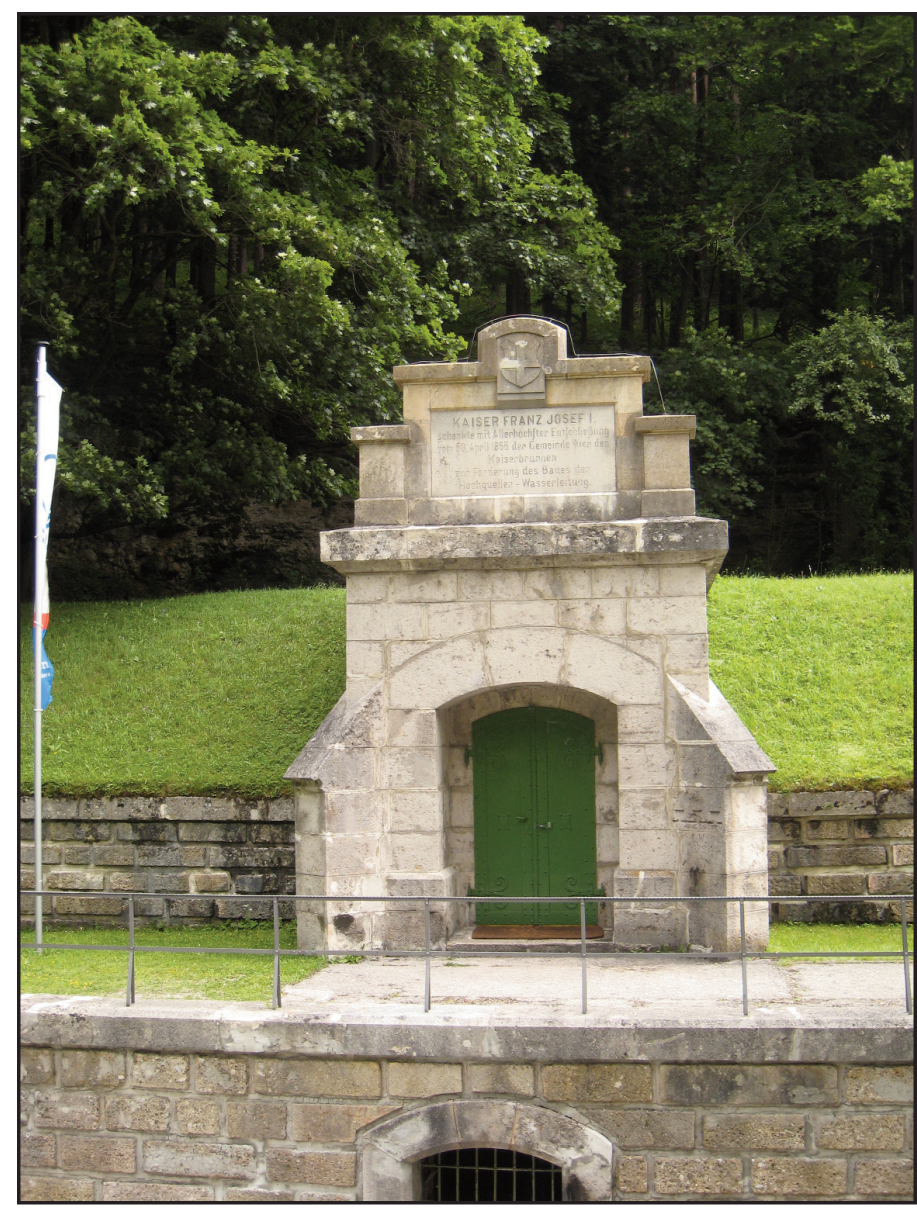

Figure 6b. The waterlock of the Hochquelle at Kaiserbrunnen.

With his book of 1862, Suess had become the founder of what we today call urban geology. He went on to propose a regulation of the main channel of the Danube in Vienna to stop its frequent flooding of the city, which was undertaken during the years 1870 to 1875 .

During all this work, he did not neglect his study of the Vienna Basin or of the Alps. In the Vienna Basin he was concerned especially with the changing environment throughout the Neogene. He noticed that every time the environment of deposition had changed, the fauna and flora, as a whole in the region, had undergone abrupt transitions. Darwin's book on the origin of species had just come out in 1859 and Suess had hailed it as a development on a par with that brought about earlier by Copernicus in astronomy and Galileo in physics (Suess 1902). Yet, what he saw in the succession of faunas and floras in the late Cainozoic beds in the Vienna Basin did not disclose a gradual change as implied in Darwin's book. Puzzled, Suess decided to enlarge the geographical scope of his investigations and not only did he visit other, correlative areas in his own country but corresponded with colleagues in the surrounding areas.

The most surprising answer to his queries came from the Russian geologist Nicolai Pavlovich Barbot de Marny (1829?1877). Barbot de Marny indicated that the same succession that Suess had found in the Vienna Basin occurred in the same order and at the same elevations, retaining horizontality, around the Black Sea and all the way to the Aral Sea. This was a most unexpected response! Suess concluded then and there

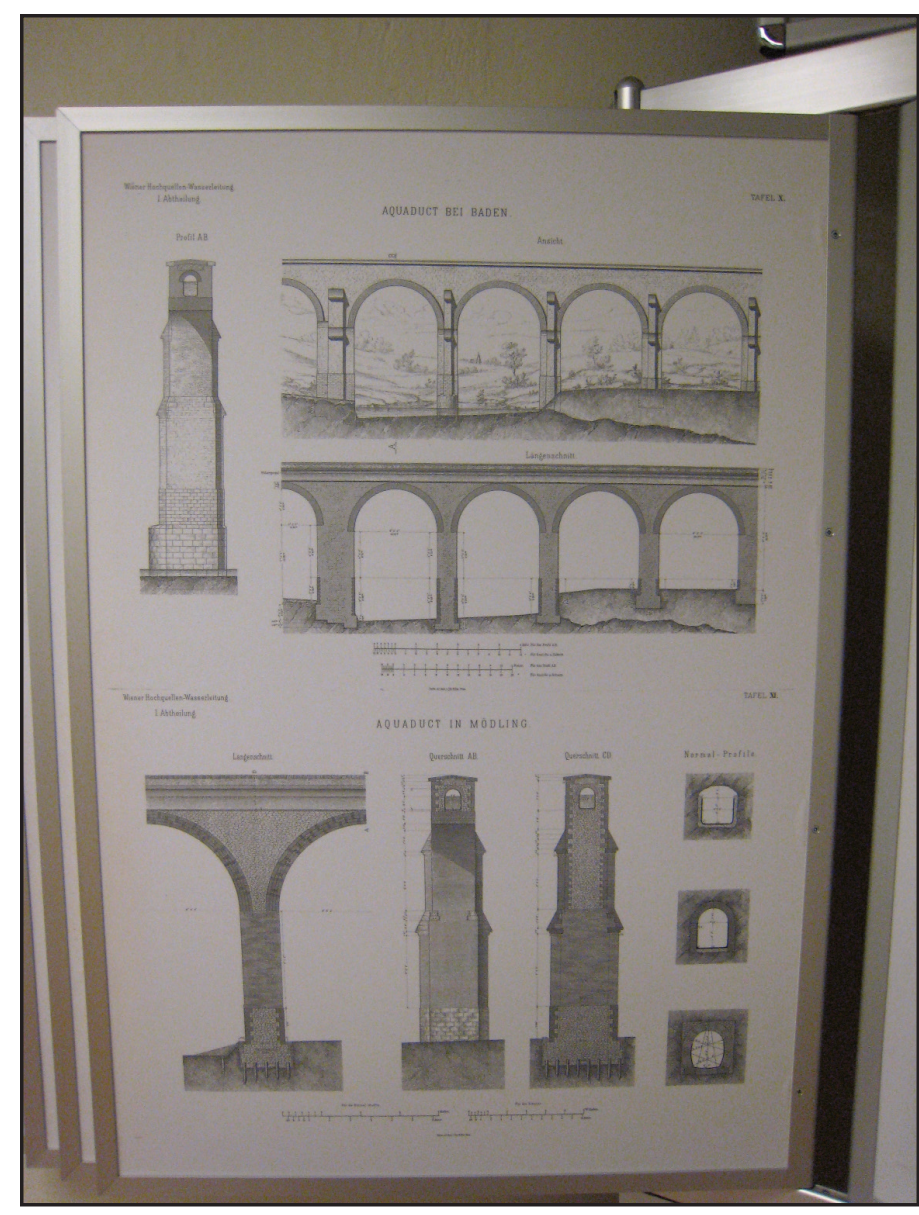

Figure 6c. A part of the plans of the aqueduct that carries water from the Kaiserbrunnen to Vienna. The segment illustrated here is that of Baden, about halfway between Vienna and Kaiserbrunnen.

that such a perfect continuity of beds now lying above sealevel at such immense distances and with no sign of subsequent deformation could not in any way be a result of continental upheaval. The sea-level itself had to have moved. This, he thought, went against everything the conventional wisdom at the time taught. After the defeat of the biblical geology and its offspring neptunism, sea-level had become a reference point that nearly all geologists considered fixed and all the movements of continents were being measured against it. A perusal of the then commonly used textbooks indicates a widespread conviction concerning the existence of secular, slow and broad-wavelength uplifts of continents. Only a very few used a more cautious language allowing the implication that the sea-level might also have been moving (e.g. von Hauer 1875 , p. 82-83).

What could have caused the sea-level to go up and down? With this question, Suess had to go far beyond the confines of the Austrian Empire or even Eurasia; the question he had just posed could only be answered by a global survey of the observations.

While he was worried about the Cainozoic rocks of the Vienna Basin and deeply concerned about their implications for the stability of world-wide sea-level, he received news of a terrible flood catastrophe in the world-famous Wieliczka salt mines south of Kraków in November 1868. The Academy of Sciences in Vienna asked him to go and study it. The salt there 


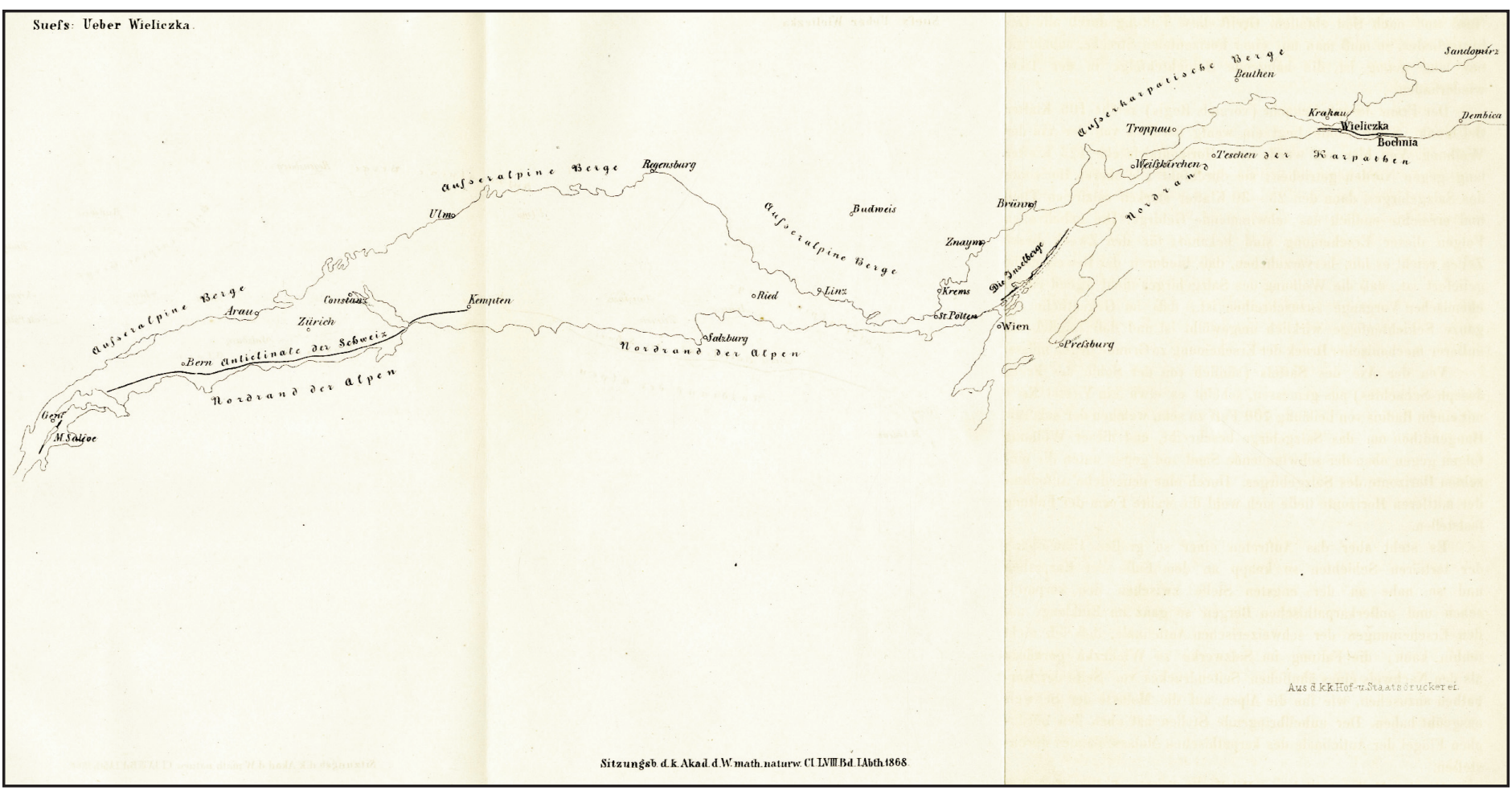

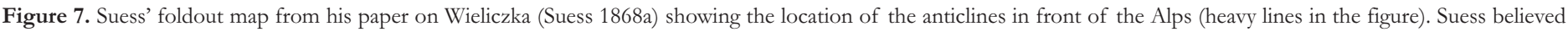
these anticlines to be parts of a single structure which indicate the northerly push of the entire Alpine body.

is part of a sequence known as the Schlier in the Alpine/ Carpathian molasse basin deposited during the late Badenian (medial Miocene) and was then folded and thrust northwards during two phases: a post-Badenian one and a post-Sarmatian one. These events created a north-vergent, almost recumbent anticline. The immense salt mine was within this anticline and the water catastrophe had occurred following an unintentional perforation into the surrounding Chodenickie clastic beds.

Suess was very impressed with the size of the anticline and how parallel it was to the Carpathian front. He remembered that a similar anticline rimmed the Swiss Alps in the north, the westernmost part of which being Mt. Salève south of Geneva. This anticline reached as far east as Kempten in southwestern Bavaria. The flysch and Klippen train north of Vienna, Suess also believed to have, or once have had, an anticlinal structure. He suddenly realized that the entire Alpine and western Carpathian chain was accompanied by a late Miocene anticline along its whole length from Geneva to Kraków (Fig. 7). Earlier, he had worked along the Carpathian Klippen belts consisting of Jurassic limestone floating in a shale/sandstone matrix consisting of Cretaceous to Paleocene flysch ('Karpathensandstein'). It had been for years a great headache to understand how these independent blocks of limestone managed to get into the younger flysch deposits. Suess had suggested that during the Carpathian deformation, the more brittle limestone could not keep up with the more easily deformed clastic rocks and consequently had burst into numerous fragments becoming embedded in the flysch (Suess 1867, p. 188; see Şengör 2003; Fig. 8). When Suess combined all these observations and inferences in his mind, he thought that a wholesale northerly motion of the entire Alpine/Carpathian body was inevitable. The resulting paper was his first tectonic publication (Suess 1868a).

\section{The Global Tectonician}

It was towards the end of the sixties and the beginning seventies that Suess started taking his students to southern Italy for field excursions. There he became impressed with the similarity of the structure of the southern Apennines to the Alps. The metamorphic rocks of Calabria and the Peloritani Mountains in northeastern Sicily he compared with the so-called central massifs of the Alps. North-northeast of Calabria, Suess noted the presence of east-vergent folds in the Basilicata and considered them a continuation of the Southern Alps. In Taormina, south of the Peloritani, he thought he could see south-vergent structures and thought they might be a continuation of the northern Alps. Along the Tyrrhenian shores of the Apennines, the presence of metamorphic rocks and metalliferous regions (e.g. the Colline Metallifere in the Tuscan Antiapennines where there is also vigorous geothermal activity) indicated that they were abruptly cut by steep faults and their inferred western continuations seemed to have subsided below the waves of the sea. These truncated coasts are today sites of active volcanic activity.

Suess was pleased with what he saw. All of these things reminded him of the Carpathians, and the volcanic rocks in the 'inner' zone of the Apennines were repeated in the 'trachytes' (actually andesite and rhyolite) of the innermost zones of the Carpathians, where normal faulting had carried the innermost parts of the chain below the young cover of the Pannonian Basin. Suess thought the Tyrrhenian Sea to be only a younger analogue of the Pannonian Basin. In 1872 he published a paper entitled 'On the structure of the Italian Peninsula' summarizing his new ideas. His most important recent emphasis was that the inner parts of large mountain ranges seemed unstable and they tended to subside creating large basins such as the Tyrrhenian Sea or the Pannonian Basin, 


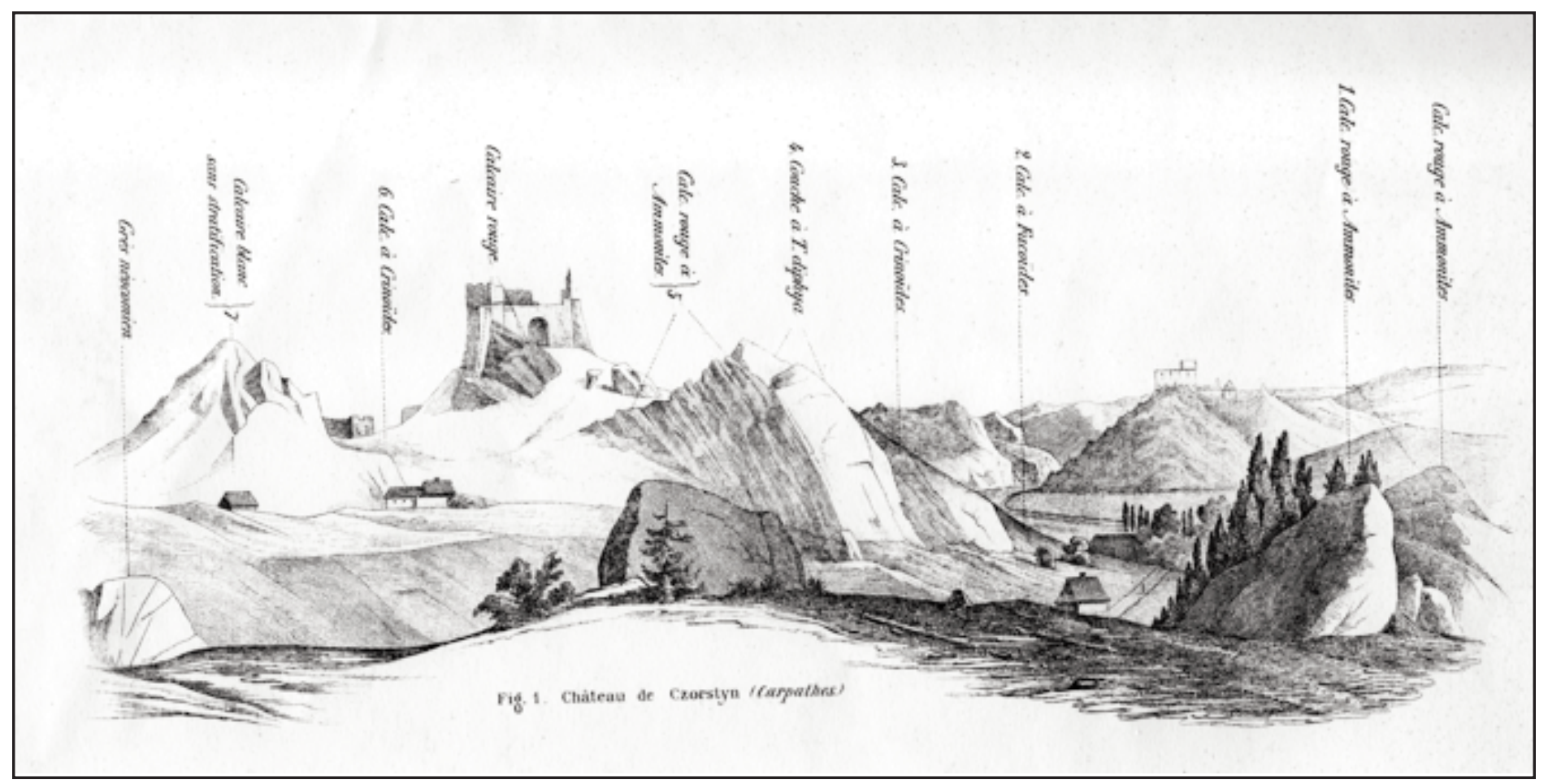

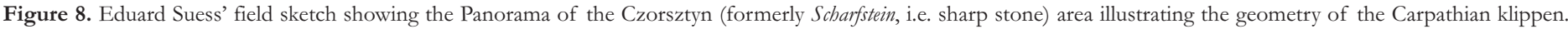

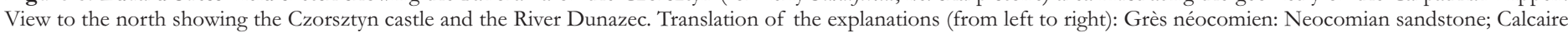

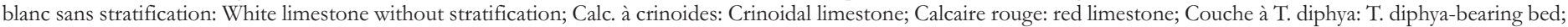
.Calc. à Fucoïdes: Fucoid-bearing limestone; Cal. rouge à Ammonites: Ammonite-bearing red limestone; ... (from Suess 1867).

while their outer parts were still shortening (Fig. 9). In that paper, Suess still considered mountains to be bilaterally symmetric structures as shown in Figure 9, although in his memoirs he later wrote that it was in southern Italy, in the Basilicata, that he had become convinced of the bilateral asymmetry of mountain structure because of the east-vergent recumbent folds he saw there in the April of 1871 (Suess 1916, p. 233). His travel companion Gerhard vom Rath (1830-1888) published a book about their joint excursion, but does not record this recognition. He only remembers how impressed Suess was by the similarity the metamorphic massif of the Sila and the non-metamorphic Apennine folds showed to those of the Alpine central massifs and the Northern Calcareous Alps (vom Rath 1871, p. 136-137). Suess' recognition came later and from a different source: from his survey of the geological literature of central and southern Europe. Later in life it seems that this recognition he projected back to his excursion in the Basilicata. Both his 1872 paper and vom Rath's book belie this.

He next considered all the major mountain ranges of Europe from his new viewpoint of the limited stability of the interior of major mountain ranges. What he saw surprised him: the mountain ranges were not symmetric structures as he had been taught to believe. They were highly asymmetric and while their outer parts were shortening, their inner parts tended to be stretched, leading to basin formation and volcanic activity. In front of the mountain ranges there was another kind of basin: the inner part of that kind of basin belonged to the thrust margin of the mountain range and was abrupt; the outer margin belonged to the foreland and was gently dipping under the basin. On $24^{\text {th }}$ July 1873 Suess read a short paper to the Academy, the abstract of which later appeared in the gazette (Anzeiger) of the Academy. This paper, until now almost uni- versally overlooked (the only reference to it that I saw is in the memoir by Hundt 1917, p. 172), is of such immense importance for understanding Suess' ideas that I here quote critical passages out of its abstract:

"The Alps do not fork in the inlet of Graz, as commonly said, instead the Middle European Mountains constitute, in their entirety from the Apennine to the Carpathians, a group of mountains that follow each other in the form of a fan. They exhibit regular folds towards the north or towards the northeast, but on the opposite side they show fields of extension and subsidence, volcanic constructions and earthquakes

The trends of all of these mountains depend on the position of the older massifs and the way they are dammed against the old massifs can be recognised not only in the French Jura, in the Swiss Jura along the southern margin of the Black. Forest, or in the course of the anticlines of the Austrian limestone zone south of the Bohemian Massif, but also the whole arc-shaped surrounding of the individual chains of the Western Alps

....

The author came to the conclusion that the entire surface of the earth is in a state of general but very slow and heterogeneous motion, which, in Europe, between the $40^{\text {th }}$ and the $50^{\text {th }}$ latitudes, is directed to the northeast or to the north-northeast. The so-called old massifs move more slowly than the regions lying between them, which form chains that are dammed up. In Middle Europe, on the polar side, regular folds are built and on the equatorial side tears are produced.

This peculiar movement of the surface of the earth behaves, with respect to the rest of the planet, like the so-called peculiar movement of the Sun spots with respect to the rotation of 


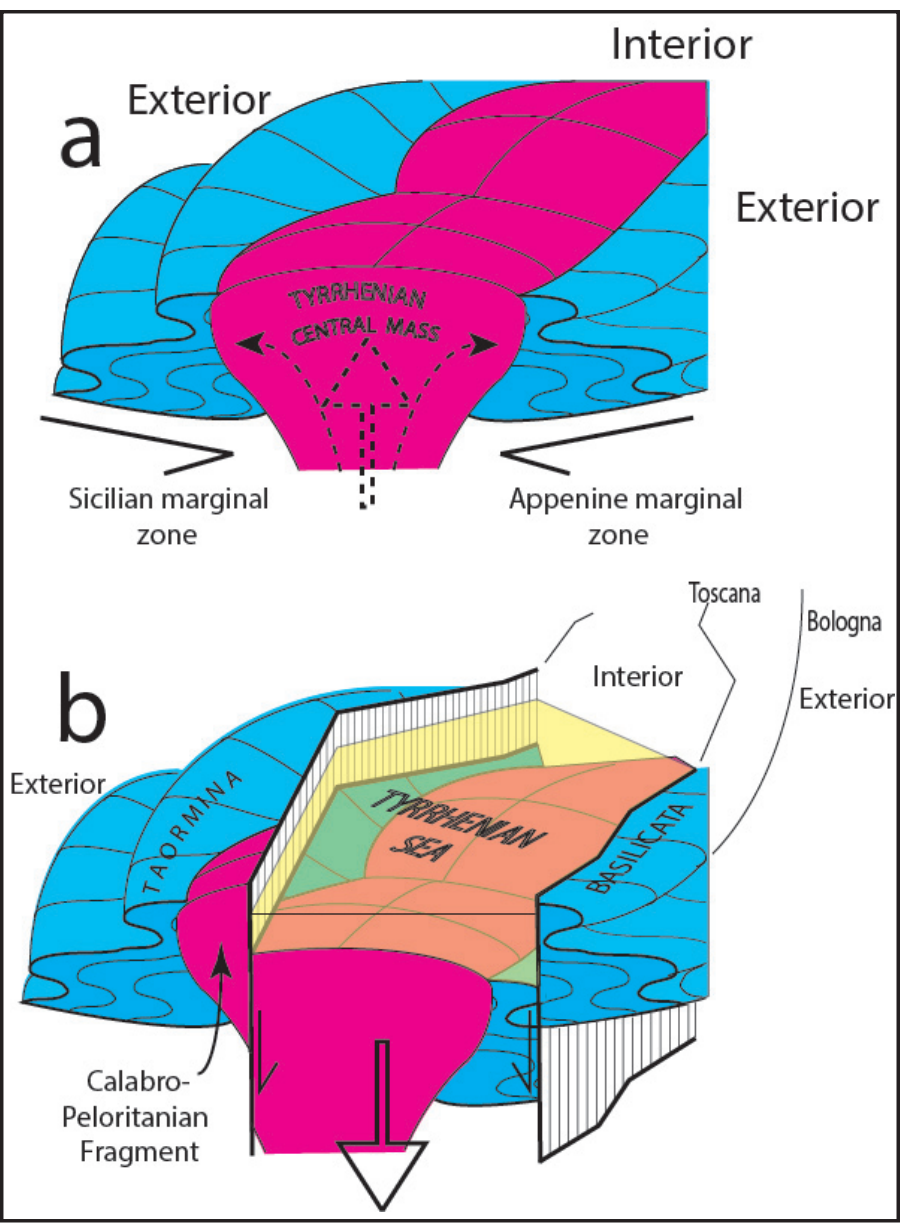

Figure 9. Suess' 1872 model (a, b; Suess 1872) for the origin of the Apennines, Tyrrhenian Sea and Sicily. He changed his mind soon thereafter.

\section{the entire body of the Sun. Their direction in various parts of}

the earth are also various." (Suess 1873, p. 130-131).

These statements are striking. There is talk here of parts of the earth's surface wandering independently of one another (Figs. 10a, b)! In his first book on tectonics, 'The Origin of the Alps' (Die Entstebung der Alpen: Suess 1875), he likened that motion to ice floes moving in drifting pack ice. Suess saw shortening in front of a block while there is extension at its back! This is nothing but continental drift even if of modest dimensions! So, can we declare Suess the first drifter? No, and for a number of reasons. First, there were drifters before him, albeit in the framework of fantastic theories that no sane geologist could have taken seriously (e.g. Owen 1857; Snider 1858). But, secondly and more importantly, Suess was prevented from pursuing his ideas developed on mountain building because of his realization that sea-level was not constant and that he had become convinced that he needed to find a mechanism of changing the capacity of ocean basins not infrequently throughout the geological history. A simple continental drift could not do that. So, he opted for something else.

The thinking that most influenced Suess in his tectonic studies came from the United States and especially from James Dwight Dana (1813-1895) as it is apparent in Die Entstehung der Alpen, the first major tectonic work Suess published and which established his reputation as a great tectonicist in the entire world. Suess admired the great work of the Rogers Brothers

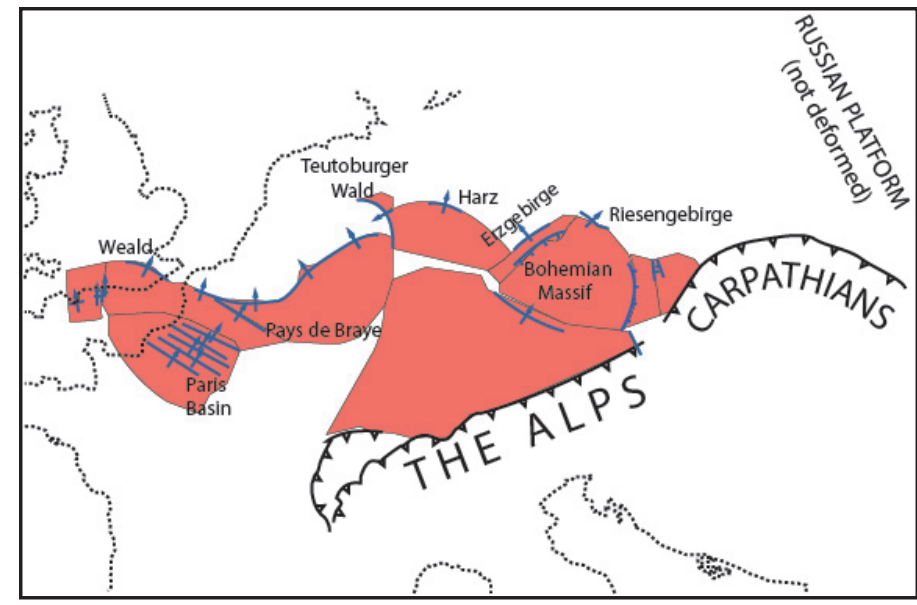

Figure 10a. The mountain ranges and fold groups in the Alpine foreland according to Suess' 1873 description (from Şengör 2014). I have attached to them arbitrary rigid blocks. Suess mentions such blocks as we have seen, but does not specify their boundaries except where their motion leads to shortening and extension. Therefore the boundaries sketched in this figure are arbitrary except for those.

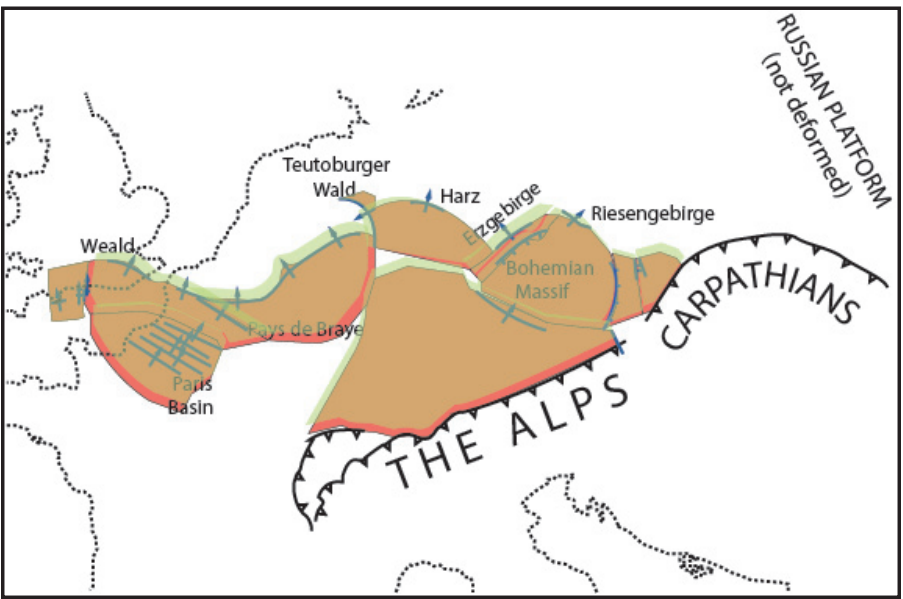

Figure 10b. The movements of the blocks Suess deduced mainly from their shortening frontal parts (from Şengör 2014). Notice that the shortening he deduced in the Alpine foreland requires extension in front of the Alps, which, however, is compensated by Alpine shortening (by the wholesale northern motion of the Alps and the northern Carpathians: Suess 1868). But the main message of this and the preceding figure is to emphasize their principle: independent motion of rigid to semirigid blocks separated by narrow zones of deformation. This is essentially plate tectonics without subduction. This is what Suess compared with the drifting of pack ice (Suess 1875 , p. 156).

on the Appalachians proving their one-sidedness (Rogers and Rogers 1843) and he approved of Dana's attempt to accommodate their results in the framework of the theory of global thermal contraction (Dana 1863). Dana had used Élie de Beaumont's version of the contraction theory, with grudging acknowledgement. But that still did not help Suess with his sea-level problem. Fortunately (or unfortunately in the long run), there was a rival contraction theory by another French geologist Louis-Constant Prévost (1787-1856) that Dana had also cited without appreciating its fundamental difference from Élie de Beaumont's. Constant Prévost's version of the contraction theory suited Suess' purpose perfectly. (Suess' interest in Prévost's work never flagged; he owned the excellent biography and assessment of the work of Prévost by his student Jules-Auguste Gosselet \{1832-1916\} published in 1896: Anonymous 1914, p. 25). 
Élie de Beaumont's theory of contraction posited a diminishing radius of an earth interior because of secular cooling and the attempt of an outer continuous layer that had stopped contracting to accommodate itself to its retreating substratum. Élie de Beaumont thought that this would happen by folding: first, a large-scale folding affecting the entire crust (he estimated its thickness to be about $50 \mathrm{~km}$ using flexure arguments which is remarkable) creating large basins and uplifts (this gave both James Hall \{1811-1898\} and Dana the idea about geosynclines and geanticlines; the original concept was thus entirely Élie de Beaumont's, but he received no acknowledgement from either of the Americans, despite the fact that they were familiar with his publications). Élie de Beaumont thought that as the basin bottoms descended they would be plunged into the hot interior of the earth and would become weakened. Eventually, they would fail and create what he called ridements, i.e. ridges consisting of fold bundles. These fold bundles would be intruded along their axes by granite bodies that would help with their upheaval. This was nicely in line with the idea that considered basaltic volcanoes products of axisymmetric uplift and not lava accumulation, which had been developed by the great German geologist Baron Leopold von Buch (1774-1853) in 1809 when he converted from his teacher Werner's neptunism to volcanism. Élie de Beaumont remained a life-long supporter of that idea.

Constant Prévost's objection came from his studies of volcanoes in Italy and in the Massif Central in France. He demonstrated to his satisfaction that in none of those volcanoes was there any sign of uplift. They all had formed by accumulation of volcanic material that gushed out from the volcanic chimney. This also agreed nicely with his previous discovery that in the Paris Basin there had been no evidence of repeated global transgressions and regressions, as his teachers Georges Cuvier (1769-1832) and Alexandre Brongniart (1770-1847) had assumed. Everything there could be explained by assuming a single, continuous regression caused by persistent global sealevel lowering. Constant Prévost pointed out that there could be no uplifts in the tectonics of the earth, for, if an uplift were to take place beneath the oceans, it would diminish the capacity of the ocean and lead to global transgression which, he believed, had never happened.

Prévost imagined that the contraction of the globe was heterogeneous (Dana later took this idea from him and it survived into the latter half of the twentieth century in the famous theoretical geophysics book The Earth by Sir Harold Jeffreys: 1891-1989; Jeffreys 1976); some regions contracted more than others. He thought that the more contracting areas would sink along steep faults, disrupting the continuity of the contracting layer, and, in the process, press against their margins creating folding. Suess happily observed that Élie de Beaumont's version of the contraction theory, which incorporated Leopold von Buch's uplift hypothesis, would generate symmetric mountain chains (which Dana had not realized despite Élie de Beaumont's explicit statement), whereas Prévost's theory would result in asymmetric ones verging away from the areas of subsidence.

In Die Entstehung der Alpen Suess adopted Prévost's global contraction theory, except that he knew that there were global transgressions. The great Cenomanian transgression particularly impressed him. He was also much taken by Prévost's actu- alistic approach as opposed to Élie de Beaumont's, the Rogers Brothers', and Dana's explicit catastrophism. That agreed with his own pro-Lyellian bias. So he imagined that now and then an area (this could be as small as the Ries Basin in Nördlingen in south Germany, which had not yet been recognized as a meteorite impact crater and was considered by Suess what he called a cauldron subsidence, or as large as parts of the Atlantic Ocean) would subside along normal faults due to superior contraction of its cone-shaped substratum with respect to its surroundings. This would make its uppermost, non-contracting part too large for the ensuing opening and it would thrust its margin. The way Suess accounted for the asymmetry of structure leading to extension behind the area of shortening was to assume a layer of detachment along which, in one eccentric spot, the largely detached parts would still be in cohesion (Fig. 11a, b). This would allow anterior shortening simultaneously with posterior extension with little deformation in the interior.

Now his global tectonic picture was complete: since all oceans were connected, subsidence in one place would lead to a rapid global regression and to mountain-building nearby, accompanied by shortening in front of the mountain range and extension behind it. In time, the hole created at the bottom of the ocean by the local subsidence would be filled up with sediment and that would cause a slow global transgression (Fig. 12). The mountains were products of horizontal shortening, not axial uplift motored by intrusions and most were asymmetric (curiously he still thought that the southern Apennines may be symmetric: the folds near Taormina in Sicily he said may represent a western flank of the Apennines). Both the location of mountain ranges and the map-view of oceans were haphazard, obeying no geometrical rule or regularity. Here is where Suess departed most drastically from all his predecessors. He saw mountain building as a continuous phenomenon lasting through periods of geological time and not phase-bound as Élie de Beaumont and Dana had thought (and continued to believe).

All these ideas Suess crammed into his little book Die Entstehung der Alpen, which, contrary to the implication of its title, dealt with mountains on a global scale and ended on a note emphasizing the intimate relationships among the various earth spheres such as the atmosphere, the hydrosphere and the lithosphere. In this connection, he introduced a new sphere: the biosphere. Suess stressed that in the geological evolution of our planet, the biosphere was a major player in its own right. His research activity was going hand in hand with his teaching (it is said that during his 44 years of teaching, Suess never missed a class) and his political activity. In 1869 he had become a representative of his city district, Leopoldstadt or simply 2. Gemeindebezirk, in the parliament of the province of Lower Austria (Niederösterreich; in those days Vienna had not yet become a province of its own) and on $20^{\text {th }}$ October 1873 he was elected into the Imperial Parliament as a member of the liberal, left-wing party. He remained a member of parliament until 1896 when he laid down his mandate ostensibly to have more time to work on his magnum opus, Das Antlitz, der Erde (Erhard Suess, in Suess 1916, p. iii; Suess 1981, p. 3). But there was another reason why Suess left the parliament, which he did not advertise, but everybody who knew him had suspected: he had realized that the increasing irrational, religious-racist and 


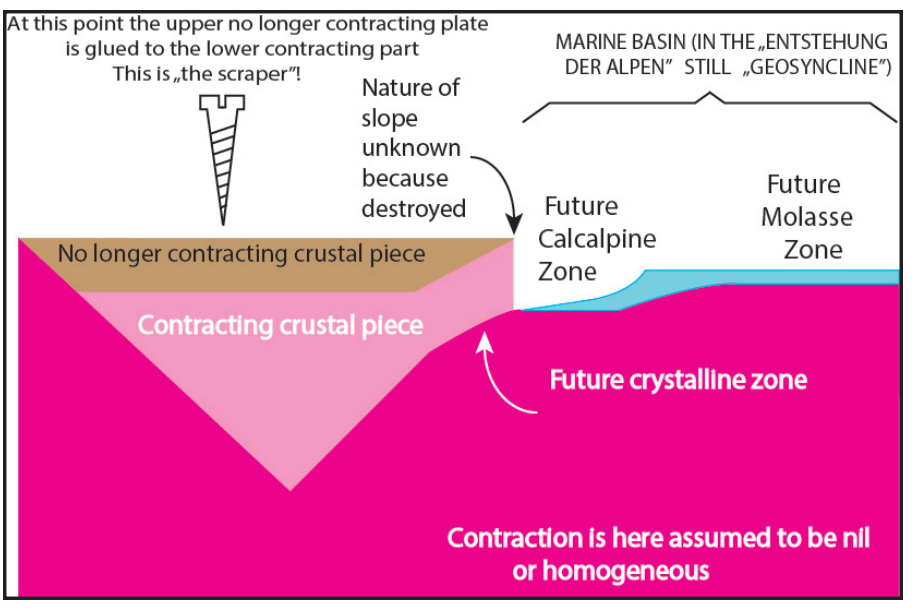

Figure 11a. The most unacceptable part of Suess' theory of orogeny for his contemporaries was that it required that while the front of a mountain is being shortened, extension happens simultaneously at its back side and that this be done on an inhomogeneously (he wrote 'unequally') contracting planet. People thought such a model needed a push from the outer space (ex-coelo Ferdinand Löwl had written) to come down to push the independently-moving blocks (Osmond Fisher, 1889, thought of convection currents, but he did not consider applying it to Suess' model of orogeny). This and the next figure show that Suess' model of orogeny was kinematically possible given three conditions: 1) that contraction be inhomogeneous. He often said it was. 2) that there be different depths of deformation, that in essence there be displacement gradients downward into the earth along which displacement may change abruptly (décollement) or gradually. This too he wrote about. 3) that at some point not in the centroid of the contracting area there be a point or area of no displacement gradient (essentially a zone of attachment of the upper non-contracting and lower contracting layers). The screw shown in this figure shows where, in the particular case here illustrated, that point (or area) of attachment will be.

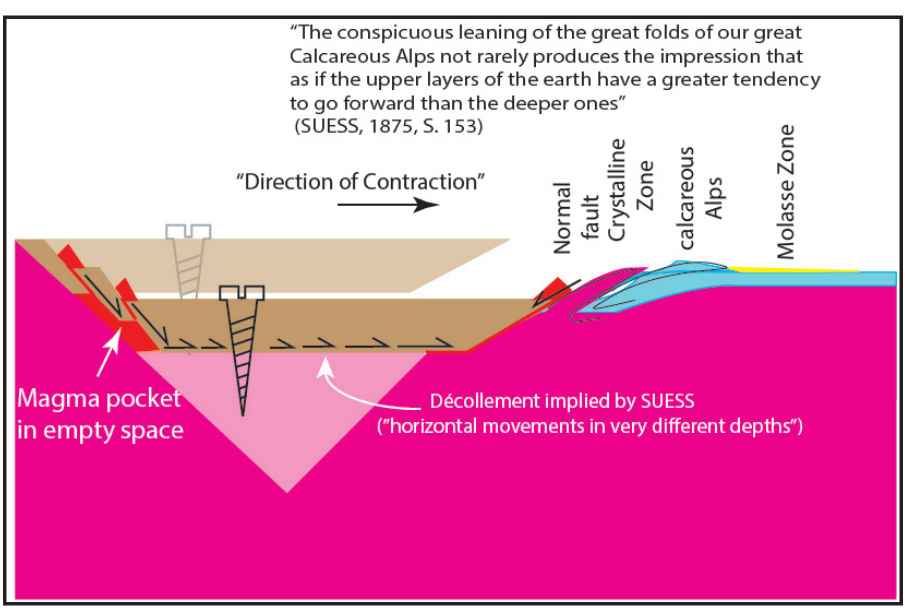

Figure 11b. In this figure the area shown in pale pink has contracted. The upper, non-contracting plate has moved forward towards the right (in the Alpine case to the north) and pulled away from the left (in the Alps from the south). So, shortening occured in front of the mountain chain and extension took place at the back. The extension created empty spaces that could serve as conduits for magma to rise to the surface creating volcanism. Here it is assumed that the non-contracting plate is not at all shortened, so it subsided as a whole except the bits in the back. This need not be the case. Instead of the foreland, the overiding plate may be shortened, or both. This would give rise to mountain formation. Dipping detachments could also have the same effect. Suess' critics evidently did not consider what he was saying in detail. They attacked him on points at which his theory was secure.

anti-Semitic tendencies in the parliament would one day get Austria into trouble and he wished to have no part in it. His forecast came true with a vengeance and only five years after his death on 26th April 1914, the Austro-Hungarian Monarchy had become history under Allied, especially American, pressure. Suess was lucky to leave this world only three months

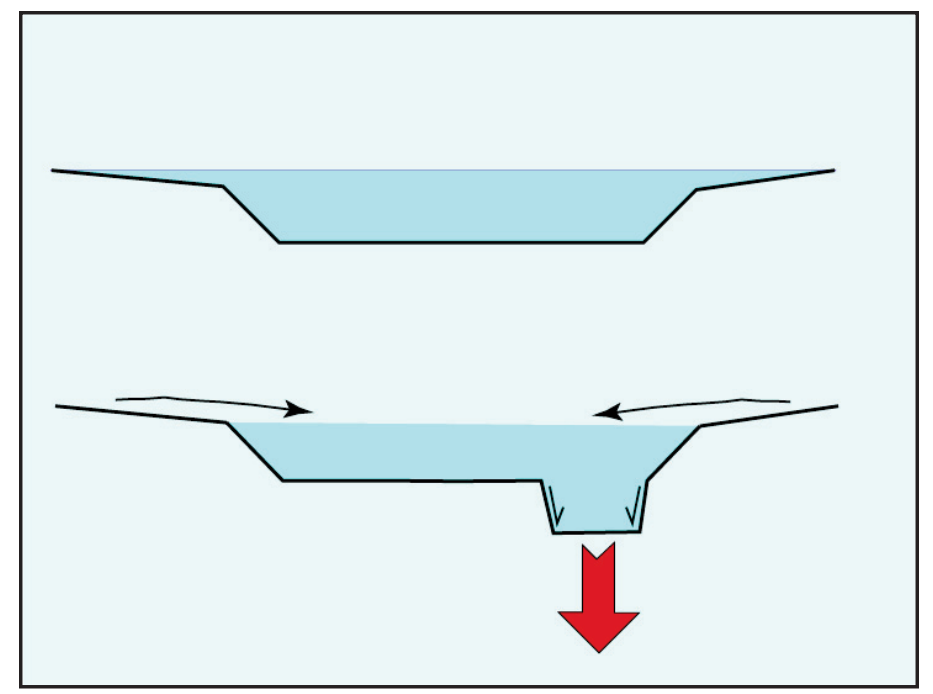

Figure 12. Suess' model for eustatic movements. When a subsidence occurs at the bottom of an ocean, the oceanic waters from the entire world are drawn down resulting in a global, i.e. eustatic, regression. When the hole is filled back, it causes a gradual transgression, because the filling by sediment is thought not to happen as quickly as the subsidence.

before his country, the country he loved so deeply, ignited World War I.

As a member of the parliament, he did wonderful things: he fought to reduce the influence of the church on schools; he championed the further regulation of the Danube to increase its usefulness as a powerful artery of communications and trade in the Balkans; he helped the further planning of cemeteries in Vienna with a view to minimizing their health hazard to the population, he contributed to the discussions on the inclusion of the suburbs into the main municipal area of Vienna; not infrequently he wrote articles for the daily newspapers (mainly for the liberal Neue Freie Presse) to inform the public of his views; he was a gifted orator and when it was advertised that he was going to speak, the meeting hall of the parliament became packed with spectators. It was said that he prepared his speeches as if he were preparing a scientific document: with carefully crafted arguments and many references.

\section{THE GREATEST BOOK THAT GEOLOGY HAD EVER SEEN: DAS ANTLITZ DER ERDE}

After having published the Entstebung der Alpen and shaken the science to its foundations, Suess could have chosen one of two routes: he could have written a textbook to advertise his ideas or he could have developed his ideas piecemeal in papers. Those two paths would have been the customary ways to proceed. Yet Suess did neither. Instead he signed a contract with the publishing firm Tauchnitz in Prague to publish a book of three volumes with the title Das Antlitz der Erde (translated into English as The Face of the Earth). The purpose of that book was to be a search for the plan of the trend-lines of the world's mountains and to trace the history of the ocean basins. Suess wanted to test the ideas he had developed until then and knew that it would be a very long process that could not be rushed into small papers. Many such books had been proposed in the past, but they all turned out not as tests of the ideas of their authors, but means of their ventilation. Suess was sincere about testing his ideas and during the 26 years it took to complete the Antlitr, he indeed changed many of his interpreta- 
tions except one: he never accepted that there could be major uplifts of the lithosphere.

The Antlitz began to be issued in instalments in 1883 as small quarto paperbacks. The first instalment was numbered volume Ia and brought the book to p. 310. This part contains the introduction and the whole of part I entitled 'The Movements in the Outer Crust of the Earth' and the two initial chapters of part II 'The Mountain Ranges of the Earth'. In the following account, all the quotations from the Antlitz are from the English edition (I first give the page numbers in the original German edition), but many have been modified by me to represent Suess' meaning more accurately.

\section{Introduction and Part l: The Standpoint of the Book and the Concepts to be Employed in it}

The introduction gives away the purpose of the book: it is to test the idea of subsidence and the idea that there are no real uplifts in the lithosphere. Suess begins with an old observation, namely the wedge-shaped southerly endings of continents: all continents, including Greenland, terminate southward in such wedges indeed: Cape Farewell (Greenland), Isthmus of Pana$\mathrm{ma}$ and the Peninsula of Florida (North America), Cape Horn (South America), Cape of Good Hope (Africa), Cape Comorin (India), Mũi Bãi Bùng (Indochina), West Cape (western Australia) and finally Southeast Cape (Tasmania). Suess rightly says that this cannot be a simple coincidence. He argues that these wedge shapes result from the intersection of two elliptical areas of subsidence (Fig. 13). But he then draws attention to the great difference in structure between the Atlantic and the Pacific margins: along the former the structures of continents are truncated and show no relation whatever to the lie of the margin, whereas in the latter the mountain ranges parallel the margins that are characterized in many cases by deep-sea trenches and these structures are obviously genetically related to the margin. In the Indian Ocean, Suess says, the western margin shows Atlantic-type structure, whereas along the Indonesian coast the Pacific type dominates. Suess points out that the great subsidence along ocean margins and other basins did not happen along individual faults, but along systems of faults.

Then he invites the reader into a classroom and briefly talks about the origin of the Solar System and of our planet. $\mathrm{He}$ points out that we read our planet's history in geological systems, stages, etc. But, he asks, what is a geological system (he calls it Formation using the nomenclature current in his day in the German-speaking world)? He points out the curious fact that the individual systems are easily recognized by the geologist in diverse parts of the world, although their nomenclature had been developed in tiny England and in restricted places in continental Europe. How is it possible, he questions, that what is established in rock successions in such a small place can be valid on all the continents? $\mathrm{He}$ argues that there must be a common cause in the origin of these sequences and finds it in the global changes in sea-level. Unconformities caused by mountain-building can not be global time-markers as Élie de Beaumont and Dana had thought, but the unconformities created by global trans- and regressions are true time markers according to Suess, because these global events cannot be explained by bobbing up and down of individual continents. He points out further that major marine terraces that formed

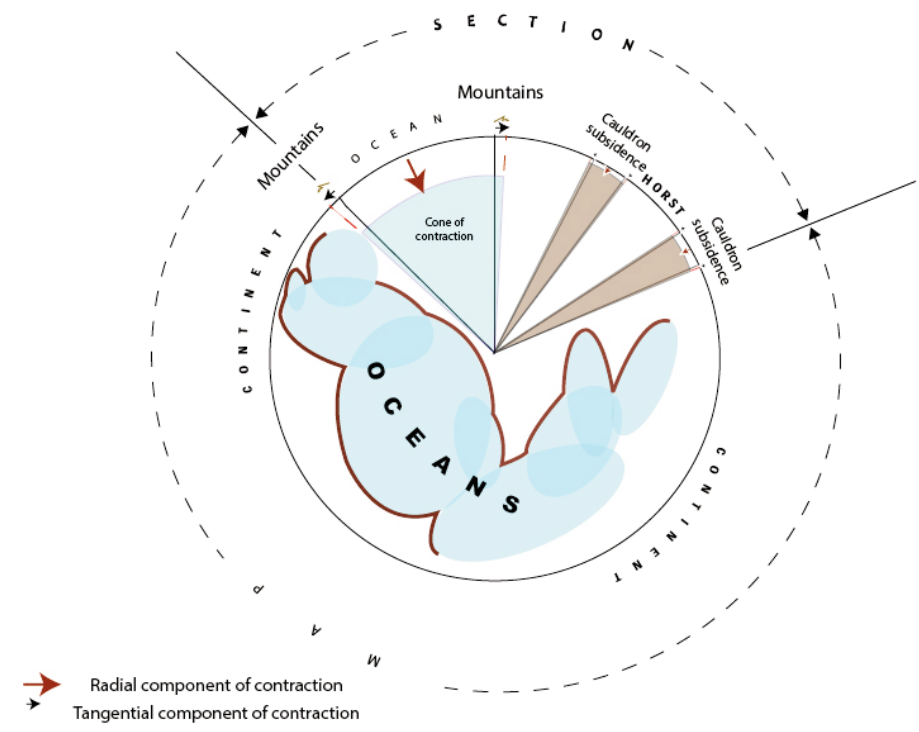

Figure 13. Eduard Suess' model of terrestrial tectonism, reconstructed from his descriptions in his two fundamental publications, Die Entstehung der Alpen (Suess 1875) and Das Antlitz der Erde (Suess 1883-1909). Suess divided the effects of the thermal contraction of the earth into a radial component and a tangential component. The radial component was supposed to be expressed by cauldron subsidences, essentially cone-shaped volumes of the earth with apices in the centre of the planet. As these sectors contracted in unequal amounts, their bases on the surface of the planet subsided differentially in shapes approximating irregular ellipses. When many such adjacent elliptical areas subsided, their coalescence formed ocean basins. In the figure, the 'section' shows cross-sections of contracting volumes. The 'map' illustrates how intersecting elliptical subsidences may form oceans. I drew them in such a way as to represent the southern and central Atlantic and the Indian Oceans, although Suess never illustrated such specific examples. His database was simply insufficient. The only purpose of this figure is to make his theory intelligible to the reader and to show that it was at the time a plausible idea to entertain. From Şengör and Atayman (2009, fig. 1, reproduced with the kind permission of the Geological Society of America, Inc.)

during the Quaternary the world over are mostly horizontal and completely independent of the structure of the coasts on which they occur. They are, according to Suess, the witnesses to the vertical displacements of the sea-level.

After the introduction, part I of the book is entitled, The movements in the outer crust of the Earth', and its first chapter is of a most unexpected kind: it is devoted to a geological exegesis of the biblical Deluge, but Suess bases his interpretation on the then newly discovered Gilgamesh Epic. Suess had become aware of the cuneiform discoveries in the southeastern Ottoman Empire by the British and sought the help of the great assyriologist Paul Haupt (1858-1926; he later emigrated to the United States and became the founder of Assyriology there as a professor in Johns Hopkins University) in the University of Göttingen to understand the account of the Deluge properly. (Suess kept up his interest in Assyriological and Biblical documents even after the publication of his Deluge chapter as can be judged by the copy of Francis Brown's 1885 book, in which the reprint edition of the first chapter of the Antlitz on the Flood was cited in the bibliography on p. 96, Christian Friedrich August Dillmann's \{1823-1894\} exegetical handbook on the Book of Genesis published in 1886, the astronomer and orientalist Eduard Mahler's \{1857-1945\} book on biblical chronology published in 1887, Haupt's teacher Friedrich Delitzsch's $\{1850-1922\}$ then controversial lectures on the borrowings from the much older Babylonian texts of the Creation and the Flood myths in the Book of Genesis in 
the Bible (Delitzsch 1903), in his personal library: see Anonymous 1914, p. 12, 17, 18 and 41; for a good summary of the Assyriological research on the Deluge and its most recent results, see Finkel 2014). The geological exegesis he presents is truly admirable: he concludes that the Deluge resulted from a storm surge caused by a tropical cyclone that entered the Persian Gulf and an earthquake that occurred during the storm. He gives examples of such coincidences in the past from various parts of the northern Indian Ocean. His purpose is to point out that this major event that stamped its memory onto the cultures of such diverse peoples was yet such a trifling event geologically. His lesson is that although the planet is measured by man, it should not be measured by man's standards. He says that the history of our planet is full of such 'catastrophes,' some much larger than 'the Deluge', but we must learn to read that history by understanding the planet's present behaviour.

The next chapter is about earthquakes. Suess shows their relation to faulting. The third chapter is entitled 'Dislocations' where Suess says that the deformations of the earth's outer rocky rind are divided into two classes, both resulting from the thermal contraction of the planet: those that result from the tangential component of the contraction: they are folds and thrusts that build mountains. The other class forms as a consequence of the radial component of the contraction: they are normal faults that bring about subsidence. Suess then introduces faults, the present behaviour of which we had just learnt in the previous chapter. The old miner's terms horst and graben (Sollas translates this in the English edition as 'trough subsidences', but also retains the term graben; in the French edition de Margerie used fosse d'effondrement, in the Spanish edition fosa de bundimiento is used, but both the French and the Spanish editions also retain Graben. Horst is used untranslated in the English and the French editions, but the Spanish edition introduces the term pilar while also retaining Horst. The very inadequate Italian translation uses affosamenti for graben and muraglia or massiccio for horsts. As we all know, in all these languages graben and horst later became naturalized) are here used for large geological structures for the first time (Suess 1883 , p. $166-167 ; 1904$, p. 126). But here graben has not yet its present meaning. Suess uses it to describe subsiding strips around circular or oval areas of subsidence, where they are bounded by a normal fault on the outside and a thrust fault on the inside. Suess thinks that thrust faults and folds of the kind seen in the Appalachians (he means the Valley and Ridge province mapped by the Rogers brothers) are shallower structures than the deep-seated faults of regions of subsidence and extension. It is also in this chapter that the concept of backfolding is introduced for structures that have an opposite vergence to the dominant vergence of a zone of shortening. Thrusting usually develops from a high area to a topographically lower area. Suess calls this the 'overthrusting of the deeps'. Suess also discusses strike-slip faults which he calls Blätter (leaves) using again an old miner's term common in the Alps.

The fourth chapter is about volcanoes where we learn about the 'denudation series', i.e. the various levels of erosion exposing different parts of volcanic, subvolcanic and plutonic apparatuses: they instruct us about the connection of volcanoes to deeper intrusions. Finally, in the last chapter of this part, Suess talks about the diversity of the movements of the earth's crust and shows that volcanic and tectonic earthquakes are quite distinct and result from different causes. He shows that tectonic earthquakes are of three kinds: strike-slip, thrust and normal fault. He returns to the discussion of the denudation series and the term batholith makes its first appearance. He thinks that batholiths fill pre-existing holes in the lithosphere. This is a mistake he would correct in the second part of the third volume in 1909 (Suess 1909a, b). We also learn in this chapter the unity of the causes of deformation and magmatism on earth.

\section{Part II: Suess' Treatment of the Continents as Then Known}

The second part of the book deals with the best-known portions of the continents of the earth bearing a misleading title: 'The mountains of the earth' and its purpose is to underpin the ideas Suess developed in his earlier publications since 1866 and to correct his earlier errors. Unsurprisingly, he begins with the Alps. But, surprisingly, instead of plunging into a description of the mountain belt, he first discusses the European foreland in front of the Alps and shows what a heterogeneous structure it has. Yet everywhere that the foreland is thrust under the Alpine front is rimmed by a foreland basin, namely the Alpine Molasse.

In the second chapter he traces out what he calls the trendlines (Leitlinien in the original; lignes directrices in the authorized French translation: Fig. 14 a) of the Alpine System. His Alpine System here comprises, in addition to the Alps, the Carpathians, the Apennines including Sicily and the North African chains including the Betic Cordillera in Spain. Before the end of volume I is reached, he includes the Banat Ranges and the Balkan Mountains into the Alpine System (Fig. 14b). These additions also show us his evolving interpretations. Suess repeats an earlier point he had already made in 1873, namely the spiral arrangement of the trend-lines of this system. He does not further discuss the issue here; instead he points out that despite the youthful appearance of these mountains, their inner stratigraphy shows that mountain building had already started in them in the Mesozoic and it is still going on. He then says that this spiral arrangement of mountain ranges is not unique to the Mediterranean and the arrangement of the Caribbean chains approximates a similar geometry.

In this chapter Suess also shows how much the structure and the sequence of events in the formation of the western Mediterranean basins reminds him of the history and the present architecture of the Pannonian Basin. In the next chapter he deals with the basin of the Adriatic Sea.

The chapter on the Adriatic is entirely devoted to showing that it too is a young basin of subsidence, but, unlike the normal-fault-dominated peripheries of the Pannonian and the Tyrrhenian basins, the Adriatic is surrounded by thrust faults, all of which verge towards the basin. Suess presents a detailed description of the contact relations of the Adamello granite/granodiorite/tonalite massif to document its laccolithic structure with a view to showing that faulting here too accompanied volcanism. He then reviews the young faults in the Southern Alps showing that they are all thrusts verging towards the sinking area and says this is yet another example of the overthrusting of the deeps. He reminds his readers that 


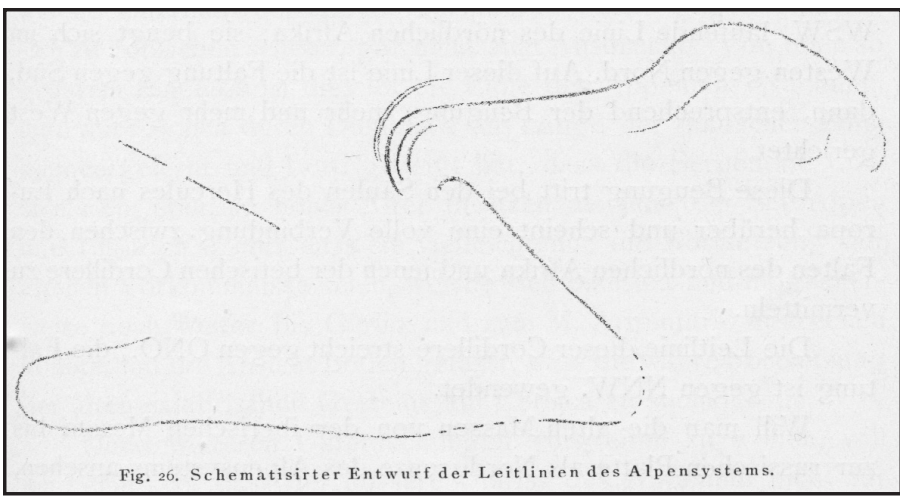

Figure 14a. Suess' first sketch of the main trend lines of the Alpine System (from Suess 1883, fig. 26, p. 303).

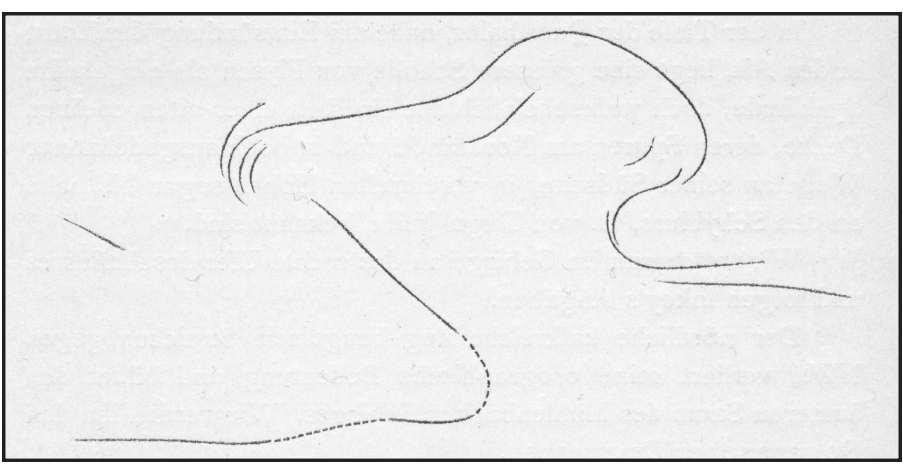

Figure 14b. Suess' second sketch of the main trend lines of the Alpine System now including the Banat Ranges and the Balkanides (from Suess 1885, fig. 47, p. 618).

the Italian geologist Torquato Taramelli (1845-1922) called a fault reaching from Barcis via Gemona to Isonzo (Soča in Slovenia) 'Frattura periadriatica' (peri-Adriatic fracture) and says that this appellation may be applied to all young faults going from the Southern Alps over the Karst Plateau and the Peninsula of Istria all the way down to Montenegro. This treatment underlines the fact that Suess' main interest here was to show that the Adriatic Basin was one of subsidence and, like the Pannonian and the Tyrrhenian, its sinking was accompanied by magmatism.

At the end of this chapter Suess presents a summary of the first three chapters of part II of his book. He repeats the heterogeneous structure of the Alpine foreland and contrasts it with the uniformity of structure of the external parts of the Alps from France to Vienna and beyond into the Carpathian external zones. As one goes into the mountains, however, the structure of the central crystalline parts again shows disunity. Suess wrote:

"It seems to me of essential importance, if we are to understand the Alps, to bear in mind the unity of their outer border; a unity so clearly expressed from the extreme west in the south of France to the extreme east in Wallachia [present southern Romania]. In this statement we include the Carpathians, for they are the immediate prolongation of the outer parts of the main chain of the Alps. This whole border, confined between the horsts, extending unimpeded over the sunken foreland, and finally advancing towards the north in a broad arc, appears, according to all that is known of its structure, to be the anterior margin of a superficial flake of the earth's crust over-riding a subsided foreland.
Crossing this border we meet towards the interior of the mountains progressively older rocks, in more or less regular order, forming chains, bands, and flakes, which are folded, overtbrust, or thrown down towards the front along long fractures, until far to the south we again reach a collapsed area. Multiform in structure is the foreland of the Alps, uniform their outer border, and multiform again the inner border. (Suess 1885, p. 349-350; in the English edition: Suess 1904a, p. 272; emphasis by Suess himself).

It is also towards the end of this chapter that Suess introduced the term virgation, a horsetail-like fanning out of individual mountain branches from a main stem, when he described the easterly divergence of the various branches from the Alps. The terminology he introduced for the description of the map pattern of the trend-lines of orogenic systems was used by himself and later by Émile Argand in his classic La Tectonique de l'Asie (1924) to represent the immense horizontal mobility within the continents. In two later papers (Suess 1898, 1904b), Suess developed the idea of the flow of continents. This idea was also later taken up by Taylor (1910) and Argand (1924) to prepare the ground for its application within the context of the theory of plate tectonics by England and McKenzie (1982, 1983). Suess' suggestion is now commonplace in interpretations of continental tectonics.

With the chapter on the Adriatic Sea, the second volume, namely Ib of Das Antlitz. der Erde published in 1885, of 'volume I' begins. The pagination of volumes Ia and Ib are continuous.

The next chapter of volume Ib is devoted to the later Cainozoic history of the Mediterranean including the Alpine Molasse Basin, the Pannonian Basin and the Black Sea all the way to the Aral Sea. It is a magnificent synthesis of the Neogene stratigraphy in which Suess distinguished four Mediterranean stages, i.e. four distinct sets of marine sedimentary rocks in the area he surveyed. This area extended all the way from the Gulf of Mexico and the Caribbean through the Mediterranean and southern and central Europe and the Black Sea to western Central Asia. One could read this chapter as a great synthesis of the regional geology of a vast area, but that is not its purpose. Suess here shows how the Mediterranean was enlarged during the later Cainozoic by the addition of such basins as the Tyrrhenian, Adriatic and the Aegean and interpreted it as a succession of subsidences. The Black Sea he also considers a young, Miocene basin. He further shows that the North Atlantic Ocean could not be much older than the late Cretaceous. He uses this information later to argue that marine basins (except the small ones such as the inlets along the Dalmatian coast) never display a synclinal structure and do not form by downbending (as Élie de Beaumont, Hall, Dana, Joseph Le Conte and almost all his contemporaries thought), but by downfaulting. That was one reason why he never believed in geosynclines: none existed today and Suess saw no compelling reason why they should have existed in the past. Here, again, his Lyellian convictions surfaced.

An interesting feature of this chapter is that Suess noticed between his second and third Mediterranean stages (i.e. between the medial Miocene and Pliocene), the enormous shrinking of the Mediterranean basin and the downward cutting of the rivers flowing into it (see Hoernes 1900, p. 813, on Suess' role in inspiring later studies on this erosive episode 
which we today know as the Messinian salinity crisis). He simply noted that it was a time of great sea-level drop somehow coincident with great tectonic events in the Alps. It is interesting that Suess, the avid reader, did not remember, or did not think relevant, James Hutton's (1726-1797) earlier suggestion that if one isolated the Mediterranean it would evaporate and immense salt deposits would be laid down:

"Let us but suppose a rock placed across the gut of Gibraltar, (a case nowise unnatural), and the bottom of the Mediterranean would be certainly filled with salt, because the evaporation from the surface of that sea exceeds the measure of its supply." (Hutton 1788, p. 242).

Had he remembered or thought relevant, Suess could have anticipated the Messinian salinity crisis (which was first discovered in 1970 in ignorance of Hutton and Suess: see Ryan et al. 1970; Hsü et al. 1973, 1977; for recent reevaluation, see Ryan 2009)!

The next two chapters deal successively with the Sahara including the Arabian Peninsula and the Red Sea as far north as the Lebanon and with South Africa and the Indian Peninsula. These chapters consist almost wholly of long and detailed descriptions of the flat-lying sedimentary rocks and the steep faults that locally deformed them (what Suess called Tafelbrüche, i.e. fractures of table-lands, in his chapter on dislocations). Using earlier observations, Suess declares the Red Sea the largest graben in the world and documents that the Dead Sea is a half-graben. His very detailed description of the isthmus of Suez (which he had personally visited as part of the official Austrian delegation in 1869 during the inauguration ceremonies of the Canal) is to show that no young uplift could be documented there. The reader begins to wonder what the purpose of such detailed descriptions of fairly boring geology of flat-lying sedimentary layers could be. The purpose emerges in the next chapter: The fact that after having meticulously described the faulted margins of the Karoo basin (and hence the southern end of Africa) Suess wrote "While the Karoo beds are thus sharply bounded on the southern and eastern side, their area becomes constricted to the north, and the western margin is made irregular by inlets of denudation. A description of the irregularities of the western border is not, however, a part of my scheme." (Suess 1885, p. 509; $1904 a$, p. 394), shows that his purpose was not regional geology, but the documentation of the corroborative evidence for a theory, namely that of origin of the oceans by fault-bounded subsidence. He made the purpose of this chapter explicit when he wrote, after having described the Jurassic and Cretaceous marine deposits of the eastern margin of Africa, "The significance of the latter [i.e. the Mesozoic marine deposits] in the history of the Indian Ocean only becomes clear from a comparison with India. This we will now attempt to make." (Suess 1885, p. 516; 1904a, p. 400-401). He aimed to show that the entire Indian Ocean was a product of subsidence along steep faults, much like the Mediterranean which he had already documented. The long description of the Sahara in the previous chapter was to show that there are areas in the world in which there had been no deformation for a very long time, similar to the Russian Platform he had described earlier, and some of these areas have been dismembered by steep and large fault zones to create oceans between them. He documents that before Cretaceous time, South Africa, Madagascar and the Indian subcontinent all belonged to a single landmass and shared similar basements and early Mesozoic terrestrial deposits with the same fossils including Glossopteris and Dycinodon. The Red Sea is for Suess only an early stage in the creation of such oceans as the Atlantic and the Indian.

The seemingly boring descriptions in both chapters are so cleverly selected that, if the reader perseveres, he finds himself at the end in front of a curtain that Suess suddenly lifts and shows the grandiose scenery of a masterful synthesis where the reader had arrived after his arduous journey through the regional details. Das Antlitz der Erde is indeed the record of a long argument in the style of Darwin's Origin of Species (1859) written in a language bordering on the sublime. So far its author convinced us that oceans like the Atlantic and the Indian, and basins like the Upper Rhine Graben in Europe, the Red Sea and the Dead Sea, the lakes Nyasa (Malawi) and Tanganyika, have all formed by subsidence along steep faults. In the next chapter he invites us back into the mountains.

In chapter seven Suess reviews in great detail the young mountain ranges that skirt Asia to the south: the Zagros and the Makran (under the designation the Iranian Arc), then the Khirtar, Suleiman and the Salt Ranges (he combines them all under the designation Hindu Kush Arc), the Himalaya and finally the Burmese Arc which he follows farther along the volcanic islands of the Andamans and the Nicobars, then through Sumatra finally to Java and the Banda arc. It is in this chapter that the term syntaxis (Schaarung: p. 545; modern orthography: Scharung; an old German miner's term used to describe the relations of veins to one another; Suess 1904a, p. 421; rebroussement, but also raccordement in the authorized French translation: Suess 1897, p. 564 and plate II) is first introduced to describe the junction of two arcs. Like the virgation, the syntaxis is an important structure betraying the horizontal movement expressed in the arcs. He may have been inspired to the idea of the flow of the continents by a comparison he made here between mountain syntaxes and the junction between the two lobes of an advancing lava flow. He repeatedly emphasizes how great the one-sided horizontal motion was along these arcs.

Suess describes numerous overthrusts, veritable nappes de charriage, towards the Indian foreland. In most of these ranges, the frontal folds and thrusts involve the cover sediments of the foreland and Suess sees herein an important difference from the Alps where the mountain and the foreland have completely different successions. The reason, he points out, is that the movements in Asia are extremely young, nay still ongoing, and much more substantial than in Europe. He also underlines (and illustrates) the role of important strike-slip faults that cut the frontal folds and thrusts.

In the eastern Himalaya he describes the weird Shillong plateau between oppositely-verging thrusts of the Himalaya and the Burmese ranges. Here, he says, there is no syntaxis, because the Burmese ranges form a unit with those farther east in Thailand and China and they strike north, past the eastern end of the Himalaya, and turn northwestward into the then recently described (by the great Russian explorer General Nikolai Mikhailovich Prjevalsky: 1839-1888) Tibetan ranges. This map-view relationship between two mountain belts, in which one cuts and terminates the other, Suess will later call, following his good and then already deceased friend Baron Ferdinand von Richthofen (1833-1905), Kettung (Suess 1909a, 
p. 578; variously rendered into English as 'linking' \{Suess 1909 b, p. 503 \} or 'linkage' \{Bucher 1933, p. 81, fig. 18c \} and into French as enchainement \{Suess 1918, p. 1369), although he himself had used the more apposite designation 'truncation' (Abschneidung: Suess 1901, p. 472-473; in French: recoupement. Suess 1912, p. 498\}) earlier.

While reading chapter seven one wonders why Suess suddenly left the fractured table-lands and began describing mountains. The answer is provided at the end of the chapter: Suess sees a homology between the peri-Indian ranges with their syntaxes and linking, and the northern margin of the Pacific Ocean. After having described the manner in which Atlantic-type basins form by looking at the mountains and the table-lands surrounding them, the natural place to continue would have been the Pacific margins to investigate the origin of the Pacific-type basins to test his contraction-driven subsidence theory. But Suess feels that the contrasts in the layout of the trend-lines of the Alpine System and the southern Asian arcs from Iran to Indonesia have now made it obligatory to investigate how these differences can be explained, before proceeding to the circum-Pacific arcs. He also feels that he should take a look at the table-lands and the mountains of the Americas, including the circum-Caribbean arcs, which form the eastern frame of the great ocean, before tackling the Pacific Basin itself.

Chapter eight begins with the description of the Tien Shan and for that Suess uses the great Russian geologist Ivan Vasilyevich Mushketov's (1850-1902) letter to him and the manuscript of Mushketov's famous book Turkestan that had not yet been published. Previous to that even topographic data from the mountain ranges of Central Asia had been so scanty that until the end of the first half of the nineteenth century, authors such as Alexander von Humboldt (1869-1859) and Carl Ritter (1779-1859) had to rely on Chinese accounts as far back as the fourth and seventh century CE (see, for example, de Humboldt 1831, 1843; for examples of his chief sources for topographic information, see Abel-Rémusat 1820, 1836; Klaproth 1826a, b; 1831, 1836; Julien 1857, 1858-the contents of this last book in two volumes were available to von Humboldt when he wrote his 1843 book; also see the von Humboldt-Ritter correspondence in which there is frequent mention of Chinese work from the first millennium $\mathrm{CE}$ as a source of physical geographical information: Päßler 2010; for the geographical work by Klaproth, see Walravens 1999; for his communication of geographical information to Carl Ritter and his relationship to Alexander von Humboldt, see the letters 69, 73 and 79 in Walravens 1999). When in 1857 and 1858 Julien finally published his complete translation of the Buddhist monk Xuanzang's (602-664 CE) account of the 'western countries' he still hoped to be of service to geographers!

In northern Asia (where Russians had complete control), the situation was better, but far from satisfactory: during the historic circum-Eurasian voyage of the Vega, Nils Adolf Erik Baron von Nordenskiöld (1832-1901) established that the Siberian shores had been mapped in many places with no less than $50 \mathrm{~km}$ errors. When these were corrected, it was found that Siberia had thus gained $28,000 \mathrm{~km}^{2}$ in area (some $5000 \mathrm{~km}^{2}$ larger than Wales; von Nordenskiöld 1882a, b, especially foldout map 11; Partsch 1899).
Von Humboldt had considered in his two books of 1831 and 1843, Tien Shan a volcanic mountain chain similar to the Andes because of misinterpretation of Chinese reports of subterranean coal fires as volcanic phenomena! This misconception was expelled by Pyotr Petrovich Semenov-Tian-Shansky's (1827-1914) expedition in 1857. Despite Semenov-TianShasky's failure to see any volcanoes or young volcanic rocks in the western Tien Shan, the aged von Humboldt was still not willing to let go of his hypothesis of the volcanic origin of the Tien Shan! After Semenov-Tian-Shansky had returned from Central Asia, von Humboldt wrote to Sir Roderick Impey Murchison (1792-1871), at the time the President of the Royal Geographical Society, the following:

"On the northern side of the great volcanic chain of TianChan, they have, it is true, discovered plutonic rocks only, such as granite and gneiss, and along the edges of the great bitter lake of Central Asia (Issingul [Issyk Kol, i.e. warm lake]) no trachytes (volcanic rocks) have been seen; but it must not be forgotten, that from the eastern shore of that lake to the Volcano of Peschan (the most western of the volcanoes of Tian-Chan, or Celestial Mountains) the distance, in a straight line, is not less than 250 English miles." (Murchison 1857, p. 71; words in square bracekts are my addition).

1857 was the year, let us remember, when Suess became a professor in the university. That the fruits of Semenov-TianShansky's expedition (Semenov 1858) formed a part of Suess' database in his 1875 book Die Entstehung der Alpen shows how drastically Suess had to change tectonic interpretations prevalent in his day.

In his writings, Mushketov assures Suess that the Tien Shan shows the same basic structure as the Alps: arcs convex in the direction of tectonic transport and igneous rocks in the inner, concave side. The only difference is that the direction of tectonic transport in the Tien Shan is towards the south; just like the marginal arcs of Asia in the south that Suess had just described in chapter seven. Tien Shan in fact consists of a number of arcs nested one within the other and northward these arcs join others. The age of mountain-building seems to get younger towards the northwest, but Suess notes that movements in Central Asia had not ceased well into the later Cainozoic.

The northern branches of the Tien Shan do not cross over into Europe, but the southern ones are continued first into Mangyshlak and then into the Donetz coal basin. The more southerly Paropamisus goes over into Turkmenistan and breaks down at the shore of the Caspian, which Suess sees as the site of an old subsidence, older than the Black Sea anyway. The Alborz skirts this area to the south and very much resembles the Central Asian chains. Between the Alborz and the Zagros, Iran is full of parallel mountain ranges and they all seem to have the same stratigraphy, so, between them, there are no pieces of older forelands. These are pinched northsouth in eastern Turkey and join the Taurus - which, according to Suess, takes up the whole of Asia Minor, exactly as the ancient Greek geographers Eratosthenes, Strabo, Diodorus Siculus and Arrian in his Anabasis had said-in a syntaxis. The syntaxis here is a site of such abundant young volcanic activity that Suess cannot be sure whether the two arcs, the Iranian and the Taurus, meet at a sharp, acute angle or are connected 
more gently by a north-convex arc. He seems to lean in the latter direction.

The Greater Caucasus presents an opportunity to correct an earlier mistake made in Die Entstebung der Alpen, where he thought it was north-vergent. Hermann von Abich's (18061886) new researches showed him that the Greater Caucasus is a huge south-vergent fold and its young volcanoes are a product of the recent disintegration of the mountain unrelated to its older structure. Beginning with what he calls Meskisches Gebirge (Moschian Mountains; the Dzirula Massif of the present geological terminology) a stratigraphy peculiar to the Taurus Mountains is seen. So this is already a different world from the Greater Caucasus. The linear Greater Caucasus continues its west-northwest trend unperturbed by the Taurus/Iranian syntaxis to the south and is connected to the Crimean chains. Suess temporarily connects the Crimean chains with the Balkan and thus with the Alps through the Carpathians. He notes that with the Caucasus and the Crimea, some north-vergent structures already begin to put in an appearance, until, in the Balkan, the entire range becomes north-vergent. He compares the Balkan/Carpathian double loop with that of the Khirtar/Suleiman and the Salt Ranges.

The Taurus continues, across the very young break of the Aegean basin, into the Grecian and from there into the Dinaric mountain ranges, which then continue into the Southern Alps. It is here that Suess finally tells his readers, why he considers the Southern Alps a separate mountain system from the main Alpine body:

"In this way a new region becomes marked out, which includes the west and south of the Balkan peninsula and the whole of Asia Minor; at the same time the strange insertion of the Dinaric branch in the Alps finds its explanation." (Suess 1885, p. 638; 1904a, p. 499)

Now we see why he did not include the Dinaric, Hellenic and the Tauric ranges within his Alpine System: according to Suess, they form an Asiatic, south-vergent element that is inserted into Europe like a northerly-curved dagger. The Alps, by contrast, are really the continuation of the Tian Shan, the Greater Caucasus, the Crimea, the Balkan, and the Carpathians. That is why Suess will call the Alps 'posthumous Altaids' later, after he defines the Altaids in volume III/1 and considers the Paleozoic mountain ranges of Europe in v. II. This method of defining mountain systems on the basis of their dominant vergence will be tenaciously followed by the main fixist Kober-Stillean tectonicians in the twentieth century, by which time Suess will have already abandoned it in his volume III/1 (Suess 1901).

Another mountain range he deals with in this chapter is the Urals and he seems to have studied it to see whether it too was a continuation of the Tien Shan. He concludes that it is not. The Ural is an independent, west-vergent mountain range, with most of its igneous rocks and the famous mineral wealth confined to its eastern slopes. But it too agrees with the asymmetric structure of mountains in general. It is also old: its material is Paleozoic. Jurassic and especially Cretaceous deposits lie flat across it.

We finally understand why we were taken so abruptly from the table-lands of the south to the mountains of the north: Suess wished to contrast the folded structure of Eurasia with the table-lands of Africa and India. Only the Indonesian arc and perhaps the Himalayan arc embrace small table-lands to the north, but Eurasia has many and wide fold belts quite unlike anything in the south or indeed anywhere else in the world. The folded arcs from the Alps to Indonesia separate these two worlds and they also seem to coincide with an old marine realm. This realm will receive the name 'Tethys' in 1893 in a small paper concerning the question of the permanence of ocean basins and continents written upon the invitation of an English editor (Suess 1893a).

The last three chapters of the first volume and with it of Part II are devoted to the Americas and to a summary of the continents covered so far. Suess begins with South America and declares it the most regularly built continent with one old mass in the east and in the centre and a large mountain range on the west. The sedimentary cover of the old mass, called the Brazilian Mass by Suess, begins with 'Silurian' (here Suess' Silurian is Murchison's Silurian encompassing what we would call Cambrian, Ordovician and Silurian) and reaches the Carboniferous. Following a large interruption, Cretaceous deposits cover it. Much of the continent was still under the waves of the ocean until at least the medial Cainozoic. Suess begins the description of the Andes in their middle, because it happens to be their best-known sector. He then follows the chain to the north and to the south. In both directions it splinters into various southeast- and northeast-trending branches forming virgations. He notes that the parallel zones of the Andes become younger as one approaches the Pacific Ocean. He says, a European geologist would expect the westernmost zone to consist of flysch; there is indeed some flysch where he expects it, but the westernmost zone mostly consists of schists and igneous rocks including serpentinite. He concludes that the foreland of the Andes is in the west, under the Pacific Ocean, just like south of the Aleutians which he mentioned earlier. He expresses surprise that the hinterland stratigraphy here reaches well into the mountain range and the volcanoes are not 'behind' the mountain, but on top of it. This reminds him of the Caucasus. Here the hinterland seems not to have broken up and foundered. The islands on the Pacific foreland are 'group volcanoes' as opposed to 'serial volcanoes' like those of the Andes; all are basaltic and have nothing to do with the Andes. In vol III/2 Suess will change his idea about the Andes and declare them an east-vergent mountain belt on the basis of newer research. This is one of the most interesting cases, where his initial gut feeling was more correct than the results of later research, showing not only his incredible intuition, but also his respect for observations. If he trusted the observations, he had no qualms about abandoning his own earlier published interpretations.

In the chapter called 'The Antilles', Suess describes three zones that remain valid all around the Caribbean: 1) an innermost zone of volcanoes and subsidence appearing in full form only in the Lesser Antilles, 2) an intermediate zone of mountainous islands consisting of Cuba and Pinos Island, Haiti, Puerto Rico, the Virgin Islands with St. Croix, Anguilla, St. Bartholomew, Antigua, the western half of Guadalupe, a part of Barbados and further the southern arc running through Jamaica, 3) an outermost zone containing only medial Cainozoic and even more recent sedimentary deposits including the Bahamas. Suess recognized that the second, i.e. the intermediate zone, resembles the outermost zones of the Andes and 
Venezuela consisting of igneous rocks, a breccia the British geologists call 'blue-beach' (the name derives from the bluebeache of the inhabitants first used by Cleve 1871, p. 4, in a geological sense; it includes, according to Cleve, all pre-Eocene rocks of the islands; now we know that rocks fitting Cleve's description consist of island arc volcanics, and volcanoclastic rocks and mélanges including keratophyres, diorites, basalts, tuffs and radiolarites, sandstones, shales and schists) and some serpentinites. Suess compares the Caribbean with the western Mediterranean: a subsided area surrounded by mountain ranges with thrust outsides and volcanic and subsided insides. He thinks that the Gulf of Mexico, a subsided foreland (with respect to Cuba and other arcs related to it), sits in the same relation to the Caribbean as does the eastern Mediterranean to the western Mediterranean.

In the penultimate chapter of volume I, Suess deals with North America and points out that it ends to the south in the Isthmus of Tehuantepec. He reminds his readers that as Alexander von Humboldt (1769-1859) and Carl Ritter (17791859) pointed out, North and South America ought to be considered two separate continents. North America has two major mountain ranges: the Appalachians in the east and the Cordillera in the west separated by a vast interior last vacated by the sea during the late Cretaceous. The Appalachians have completed their evolution in the late Paleozoic. They are west and northwest-vergent and the Atlantic Ocean subsided along faults located in the inner zones of the Appalachians. This agrees with Suess' model of mountain- and ocean-making. The Cordillera is younger and much more complicated. Suess considers that the U.S. Rockies are a consequence of subsidence of basins around them and the remaining highs overthrusting the subsided areas. He considers the Sierra Nevada a west-facing large fold. Although he spells it out clearly nowhere, one gathers the impression that he thinks the North American Cordillera also a mainly west-vergent chain. Here too, the foreland is the Pacific Ocean. In Alaska, that is definitely the case.

The last chapter is entitled 'The Continents' and Suess begins by pointing out that the expressions Old and New World are geologically meaningless (this was possibly a reaction against Alexander von Humboldt's frequent reference to the Americas as the New World). He discusses the question as to what is meant by the age of a continent and temporarily chooses to mean by it the time of the last retreat of the sea from above a substantial piece of land (hence -Land in Gondwana-Land signifies continent, not country, as some illinformed authors previously claimed: see Șengör 1983, 1991; that is why it is simply wrong to call Suess' supercontinent Gondwana. Its proper name includes -Land indicating that it refers to a continent and not to the historical region Gondwana in India). In a review of this paper, Paul F. Hoffman asked whether the land area should be called Gondwana-Land and the continent itself be referred to as Gondwana. This would still be wrong from Suess' viewpoint, because Suess' continents as land areas were defined as fault-bounded horsts rising amidst the surrounding oceans and the shelves were included into the continent. This is similar to our present concept of a continent. Moreover Gondwana is the name of a historical region in India that has given its name to a number of geological concepts such as the Gondwana Plateau or the Gondwana Flora.
Suess points out that there is no common designation for what is traditionally called the Old World. He borrows the term Eurasia from zoogeographers and applies it to the landmass north of the Alpine-Himalayan marginal arcs. To the south is what he calls Indo-Africa, of which India, Madagascar and South-Africa are characterized by the Gondwana flora. Suess calls that part, including the zoologist Philip Lutley Sclater's (1829-1913) Lemuria (India + Madagascar + Africa + parts of South America: Sclater 1864, p. 219), GondwánaLand. In the subsequent volumes, Gondwána-Land will acquire a much broader meaning including all of South America, Africa, Madagascar, India and Australia. Only in the last volume Suess will separate an Australia and Antarctica from Gondwána-Land, because, unlike the rest, Australia carries evidence of various Mesozoic transgressions (Suess 1909a, p. 576), despite the fact that the Glossopteris holotype (Glossopteris browniana) comes from Australia (Steve McLoughlin, personal communication 2014; see Brongniart 1828a, p. 223-224; $1828 \mathrm{~b}$, plate 62; the name Glossopteris browniana had already appeared, with a brief description and locality indicated as 'New Holland \{i.e. Australia\} and Indies' in the Prodrome: Brongniart 1828c, p. 54). If this looks insufficient evidence to separate a continent from another let us remember that Suess temporarily defined the last emergence from the waters of the ocean as a common characteristic of a given continent.

Suess will argue in his last volume that Antarctica contains Graham-Land, which he thinks a continuation of the Andes, and, for the rest, resembles Australia.

Suess thus distinguishes a South and a North America, an Eurasia and an Indo-Africa. Australia and Antarctica are not yet considered. The Mediterraneans, both in Eurasia and between the Americas, formed by subsidence. Only the bit of the Mediterranean of the Old World lying south of the Cyprus arc Suess assigns to Indo-Africa. It, too, is a product of foundering along steep faults. He reminds his readers that the 'great catastrophes' such as that represented by the 1883 eruption of the Krakatoa or even the biblical Deluge are trifling geological events compared with the building of mountains and oceans.

He summarized:

"The stresses which resulted from the contraction of the outer part of the body of the earth are transformed, as we have said, into tangential folding and vertical subsidence. By the tangential movement those long folded ranges are produced which traverse the continents from end to end;...

A great number of regions, such as Indo-Africa, have experienced no kind of folding movement for a long time; the part they play is to check the folds or to subside in front of them. Movement in the second direction, i.e. subsidence or collapse, has on the contrary left its traces everywhere. Sometimes it produces great troughs in the midst of table-lands, sometimes subsidence of plateaux along peripheral lines, at others cauldron shaped in-sinkings on the inner border of folded mountains, and at others again the subsidence of folded mountains along longitudinal transverse fractures. The diversity in character of the effects produced by downward movement is extraordinary, and their magnitude extremely great. It is to subsidence and collapse that the Mediterranean seas and the largest oceans owe their origin and enlargement." (Suess 1885, p. 777-778; 1904a, p. 603-604). 
He ends the first volume by emphasizing that "The breaking up of the terrestrial globe, this it is we witness" (Suess 1885, p. 778; 1904a, p. 604).

\section{Part III: The Oceans and the Seas of the World}

Suess devoted the entire second volume of the Antlitz and thus the third part of his book to the structure and history of ocean basins and the chronology of global transgressions and regressions. Therefore, this second volume (and Part III) is subtitled: 'The Seas of the Earth.'

In the first chapter he provides a thorough review of the ideas about sea-level change beginning with the great Amaseian geographer Strabo's (ca. 63 BCE-24 CE) Geography (Suess owned Christoph Gottlieb Groskurd's \{1770-1834\} scholarly translation into German in 4 volumes \{Groskurd 1831a, b, 1833, 1834\}; see Anonymous, 1914, p. 60; he seems to have continued his interest in Strabo: he owned, for example, Marcel Dubois' 1891 book, very critical about Strabo's accomplishments as a scientist: Anonymous, 1914, p. 19) and, interestingly, Dante Alighieri's (1265-1321) famous lecture entitled Quaestio de Aqua et Terra delivered on 20th January 1320 in the church of Santa Elena in Verona. The thoroughness of Suess' review is truly admirable. At the end, he cites George Bellas Greenough's (1778-1855) plea in his 1834 presidential address to the Geological Society of London, in which he critically examined the evidence for land uplift in the world, for a neutral terminology of sea-level change without implying either the land or the sea-level itself moves, in that he used with emphasis the expression change of level (Greenough 1934, p. 59). Suess follows the lead of Robert Chambers (18021871; of Vestiges fame) in his 1848 book on sea margins to talk about the 'movements of the strand' (Chambers 1848) instead of movements of land or the sea. He proposes to call a landward migration of the strand a 'positive' movement and the reverse a 'negative' movement.

He points out that there are three ways to study past sealevels: 1) to study the distribution of past seas which can be done by studying their deposits; Suess says that through this method the negative movements will be harder to identify and study, because of erosion. 2) The second method is to study the character of sedimentary rocks. Darwin had argued that sediments would be deposited only in a sinking marine basin. Suess points out that this is certainly not the case. 3) Finally one can study the present-day shoreline and its terraces. This is useful only for the youngest shorelines and only for negative movements. He also warns about real uplifts of land during earthquakes with an example from New Zealand.

The second chapter describes the margins of the Atlantic Ocean. However, Suess keeps his descriptions so comprehensive that almost the whole of western and central Europe, for example, is included. In 1886, he had published a small paper on episodic folding in Europe, in which he had defined the Caledonian Mountains in the north (pre-Devonian), Armorican and Variscan arcs in the middle (pre-Permian) and the Alpine System, the construction of which continues (Suess 1886). He incorporates those results into this chapter. The next chapter reviews the Pacific margins. The margin of Asia is not drawn at continental shores, but in front of the island arc systems. He writes, as a general summary of this chapter:

"With the exception of a part of the coast of central
America in Guatemala, where the bending of the cordillera of the Antilles has sunk in, the whole border of the Pacific Ocean, wherever it is known in any detail, is formed of mountain chains folded towards the Ocean in such a manner that their outer folds either form the boundary of the mainland itself or lie in front of it as peninsulas and island chains. No folded range turns its inner side to the Pacific; no table-land reaches the shores of this Ocean." (Suess 1888, p. 261; 1906, p. 204; emphasis by Suess).

Pierre Termier, the discoverer of the Tauern Window and a eulogist for Suess and his book, thought that Suess identified the Atlantic margin of the United States and Canada as a Pacific-type margin, from which I can only conclude that he never read the book with any thoroughness, for, otherwise, he could not have made such a gross mistake. In another place on the same page, Termier thinks that Suess had implied that the Pacific-type margins are not faulted (Termier 1920, p. 5)! This essentially clinches my point that Termier never read the Antlitz completely or carefully. I also remember years ago a conversation with the noted American geologist John Rodgers (1914-2004) of Yale University: he referred to this sentence of Suess saying that he had read it and found it absurd; he could not understand why vergence towards or away from an ocean was relevant. I was shocked! Termier's and Rodgers' statements were two of the many instances telling me how little the geologists active in, or raised during, the Dark Intermezzo understood what Suess had said and how much their teachers, who themselves had not read or undestood what Suess had written, were responsible.

In the last page of this chapter is also Suess' first salvo against Dana's geosyncline theory (which was taken by some of his readers as a support for geosynclines leading Suess in the last volume to write that he regretted having used the term earlier in his book: Suess 1909a, note 562 on p. 737-738, 1909b, p. 627):

"Further we can now clearly recognise that the hypothesis of the formation of folded chains by the thrusting from the Ocean towards the land of the border of a sinking basin or geosynclinal is in no way founded on fact. There is no geosynclinal in the world greater than the Pacific, and the mountain ranges so far from being turned away from it, are turned in the opposite direction, facing it, and so afford an example of the grandest scale of the general tendency to overthrust the depressions (I, p. 143).” (Suess 1888, p. 263-264; Suess 1906 , p. 207).

In the next three chapters, Suess reviews the history of the Paleozoic, Mesozoic and Cainozoic seas as represented by their deposits on land with a view to establishing a chronology of transgressions and regressions. After a breathtaking review of global stratigraphy he comes up with the following time-table:

Pliocene: Very limited transgression

Latest Miocene: Maximum regression

Later medial Miocene: Regression

Later early Miocene Burdigalian: Transgression

Earlier Early Miocene (Aquitanian): Regression

Oligocene: Transgression

Eocene-Oligocene transition: Regression

Eocene: Transgression

Latest Cretaceous: Regression

Early to medial late Cretaceous: Transgression 
Latest Jurassic: Regression

Late Triassic to medial late Jurassic: Transgression with oscillating sea-level

Permian: Very limited transgression

Late Carboniferous: Oscillations accompanying a regression

Later early Carboniferous: Transgression

Early Carboniferous: Regression

Medial Devonian: Transgression

End of Silurian: Regression

He does not discuss the Cainozoic deposits world-wide, because the record is both very rich and yet very unequal; the Cainozoic rocks of the circum-Pacific, for example, have been hardly studied, except in California. The world-wide synchroneity of the large transgressions and regressions leaves little doubt about the existence of the movements of the sealevel independent of the movements of continents; these global sea-level changes Suess now calls eustatic (Suess 1888, p. 680). Figure 15 shows a comparison with the most recently available global sea-level chart by Bilal $\mathrm{Haq}$ and his colleagues (Haq et al. 1987, Haq and Al-Qahtani 2005, Haq and Schutter 2008; Haq 2014), which Professor Haq most kindly supplied upon my request, and the eustatic time-table by Suess. I asked Haq to comment on my comparison and received from him the following note:

"Modern long-term sea-level curves are based on multiple criteria, such as continental flooding data, oceanic crustal production rates (including changes in the mean age of the oceanic crust, seafloor spreading rates and ridge length and emplacement of large igneous plateaus and hotspots on the seafloor) and sediment input into the ocean. More recently other factors, such as vertical crustal elevation changes brought on by dynamic topography of oceans and continental margins, have also become important considerations. The latter, in particular, implies that no measure of sea-level change gleaned from a single margin can represent a global sea-level change. Such eustatic measures can only be approximated from widely distributed stratigraphic and geophysical data. Thus, in spite of the fact that many of these issues were unknown at the time of Suess' synthesis, his sea-level curve shows remarkable similarities to the modern curve for the Devonian through Permian part of the Paleozoic and the early Cenozoic. The differences in the Mesozoic and minor offsets elsewhere can be ascribed to changes in our concepts of Stage boundaries and time scales in general in the $20^{\text {th }}$ Century, as well as regional tectonics that may have biased Suess' interpretations." (written communication, 13th September 2014).

Suess gave no quantitative estimates for the rise or fall of sea-level compared with the present stand but simply indicated times of transgression and regression. Because of that I indicated times of transgression and regression by full arrows and those of limited transgression (those expressly indicated by Suess) by smaller arrows. Wherever Suess indicated rapid oscillations, they are indicated by double small arrows. Therefore, Suess' side of the diagram seen in Figure 15 is only a qualitative indication and is not to be compared quantitatively with Haq's curve.

One would think that these three chapters should have satisfied Suess to show that there are eustatic movements. But do not let us forget that his real aim was to show that there are no large scale uplifts of the lithosphere. Accordingly in the next two chapters he examines two classical places where the presence of such uplifts had so far been claimed to be unequivocal.

Chapter seven is devoted to the alleged high marine terraces of northern Norway near Tromsø. In 1885 from June to September he had been in Norway with his physician friend Dr. L. Burgerstein checking out the terraces claimed to be the witnesses of former higher sea-levels (see Suess 1916, chapter XXII, p. 365-372). He convinced himself without much trouble that the terraces all the way to Tromsø are actually evidence of the former levels of the lakes formed by ice blocking up fjords.

The two friends then journeyed farther south and southeast. A local expert, Karl Johan Pettersen (1826-1890), suggested itineraries. The seter (or setär) were like numerous benches cut into bedrock. Their number and their elevations failed to correlate from one fjord to another. Suess noticed that they become numerous and higher toward the heads of the fjords. Seters turn around and in places join terminal moraines. As far as he could see from the existing maps, and an aneroid altimeter he had wisely brought with him, they were also horizontal. In the Antlitz he discussed the older reports such as that by Bravais (1842) indicating the presence of tilted terraces and showed that Bravais' observations were not made on the horizontal terraces and therefore could not invalidate his argument (Suess 1888, p. 441-442; 1906, p. 347-349). Nowhere did Suess see any marine fossils on them and neither had anybody else before him (Suess 1888, p. 430). They thus could not have been cut by the waves of the ice-age ocean. Suess thought that they could not be marine terraces, but erosional terraces of once existing lakes between the bedrock and the moraines containing them seaward.

Lower down were genuine marine terraces, but Suess ascribed them to sea-level that he thought stood higher during the ice ages following the conventional wisdom of his day. Today, rise of sea-level along the periphery of an ice cap because of the gravitational pull of the ice mass is well known, corroborating Suess' ascription (Clark et al. 2002; Bamber et al. 2009). Unfortunately he did not discuss Croll's $(1875,1885)$ deductions concerning glacio-isostasy because he was fundamentally against the idea of swimming continents.

The richness of Suess' observations in northern Norway, the ingenuity displayed by him in interpreting them with the aid of a vast array of both comparative and theoretical arguments about the terraces of northern, western and southern Scandinavia, are truly awesome. His arguments range from fluvial and glacial geomorphology, through climatology to hydraulic engineering. For all his ingenuity, boundless knowledge, and great ability as a field geologist, we know now that Suess' insistence that no uplift could be seen in Scandinavia was wrong. In chapter ten, he argued, using an incredibly impressive array of datasets gathered from the literature and in correspondence with people responsible for keeping track of sea-levels in the Gulf of Bothnia and the Gulf of Finland, that the terraces around the Bothnian Gulf were created by different sea-levels controlled by climatic and oceanographic conditions, including fluctuations in salinity of these restricted seas governed in part by marine current conditions in narrow straits, thus in essence almost going back to the ideas of Emanuel Swedenborg (1688-1772; Suess owned the book edit- 


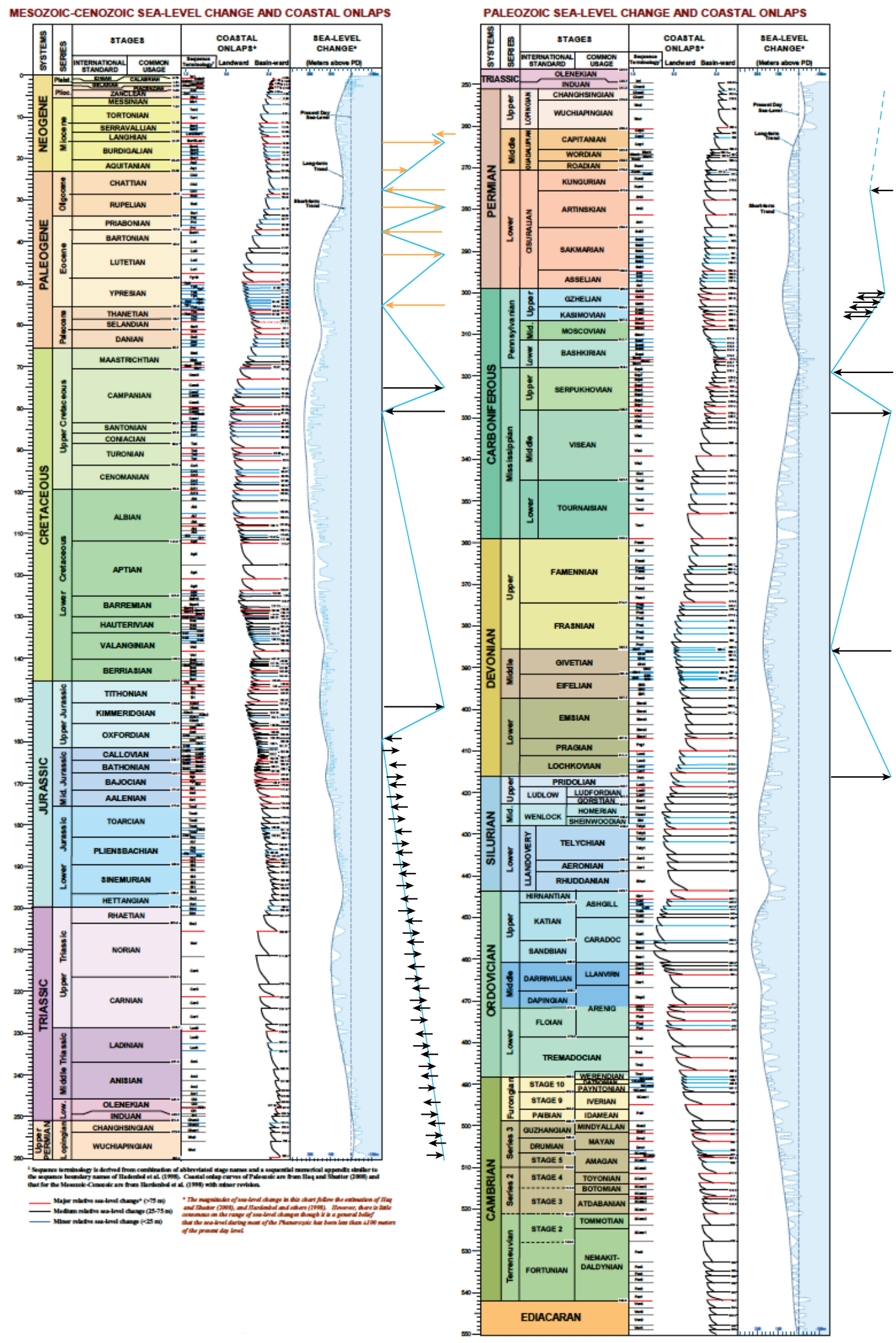

Figure 15. A comparison of the eustatic movements deduced by Eduard Suess on the right and the most recent estimates kindly supplied by Bilal Haq (written communication, 13th September 2014). Suess gave no estimate of the actual amounts of he rise and fall of sea-level; he simply contented himself to report global transgressions and regressions. In this figure, times of transgression and regression are shown by me with full arrows and those of limited transgression (those expressly indicated by Suess) with smaller arrows. Wherever Suess indicated rapid oscillations, they are indicated by double small arrows. The Cainozoic data were mainly from Europe; Suess claimed no global validity for his Cainozoic curve. 
ed by the Swedish Swedenborg expert Alfred Henry Stroh \{1879-1922\} of German-American descent, containing the papers by Alfred Gabriel Nathorst \{1850-1921\} on Swedenborg as a geologist, by Svante August Arrhenius \{1859-1927\} on Swedenborg as a cosmologist and by Stroh himself on Swedenborg's early philosophy of Nature \{Stroh 1910\} and Stroh and Ekelöf \{1910\}: see Anonymous 1914, p. 45) and Anders Celsius (1701-1744; see Celsius 1744). Nothing shows better than this chapter the aim of Das Antlitz der Erde as a theoretical long argument against the uplift theory.

In chapter nine, intercalated between the two Nordic chapters, we are taken to the so-called 'Temple of Serapis' in the Gulf of Pozzuoli, west of Naples. This structure, the Serapeo, which is now known to have been not a temple but a macellum, i.e. a fish and meat market, is the classical locality, where Sir Charles Lyell had thought that evidence for vertical oscillations of continents was incontrovertible. Suess did quick work of that claim by pointing out, using the renowned Italian geologist, malachologist and archaeologist Arturo Issel's (18421922) synthesis (Issel 1883, especially map facing p. 177), that nowhere else along the Italian shores movements in sympathy with those in Pozzuoli could be seen. It was clear that the Serapeo was sitting on a magma chamber the episodic filling and emptying of which determined the elevation of the macellum on top of it. Suess was careful to underline, however, that the emptying and refilling of the magma chamber did not correspond to the eruption time-table of any of the nearby volcanoes including the majestic Vesuvius. Modern research has entirely vindicated Suess' views in all these aspects (e.g. Dvorak and Berrino 1991; Orsi et al. 1999; Battaglia et al. 2006; Bodnar et al. 2007).

In the eleventh chapter Suess reviews the record of the Mediterranean shores with a view to discovering whether any changes of level occurred during historical time. He starts with the physical oceanographic conditions of what he calls a chain of sea basins from the Sea of Azov to the Strait of Gibraltar. He first shows that because of differences in salinity, and therefore density, not all parts of this basin chain have the same sea-level height. He identifies the Azov, Black and the Marmara seas as 'active regions', i.e. those whose surface stands higher than the rest of the Mediterranean and therefore send their waters outside, whereas the main Mediterranean is a 'passive region', because it accepts water not only from the previously named tributary seas, but also from the Atlantic Ocean owing to strong evaporation. The lowest level is seen between Crete and Libya. As was done in the case of the Baltic Sea, such level differences are reviewed also in the Mediterranean and its satellite basins first as a warning to the reader stressing the difficulty of establishing small variations of level to address the question whether there are continental vertical motions. Suess then looks at the spits and barrier islands around the Azov Sea and the Black Sea, including the Isthmus of Perekop, Strabo's famous 'Course of Achilles' (Geografikon, VII, 3.41), and observes that no changes of level had occurred there since the earliest descriptions by Strabo had been written eighteen centuries earlier. There is evidence of higher sea-levels around the Black and the Marmara seas, but just before the historical era. From the presence of the low islands of Jerba and Kerkennah in offshore Tunisia consisting of recent accumulations and which had been known to Herodotus (Istoria,
IV, 195), through the fossils of still living species along the Algerian and the Gibraltar coasts and from the position of the canal of St. Louis (Grau Louis) near the town of Aigues-Mortes (=Aquae Mortuae, i.e. dead water) west of the Rhône delta, to the presence of Roman roads on coastal barrier islands in Italy, the record clearly indicates that no detectable sea-level change has occurred in the western Mediterranean during historical times.

Suess' investigation whether any serious sea-level change occurred in the eastern Mediterranean during historical times begins with Venice (a part of the Austrian Empire until 1866) and he shows that the subsidence in Venice is a consequence of the settling of the sediments underlying it. All the way from the Dalmatian coasts to the Gulf of İskenderun (ancient Gulf of Alexandretta) near Antioch (present-day Hatay in southern Turkey), Suess points out that reported rise of sea-level during historic times is a result of sediment settling in old harbours and the reported falls of sea-level are consequences of results of faulty observations such as the alleged presence of holes created by rock-eating bivalves in old Lycian sarcophagi. In the Dead Sea and its associated lakes and in Egypt, Suess finds no evidence that sea-level was any different from what it is today during historic times.

The evidence he presents to underpin his case of the stability of sea-level around the Mediterranean, including climatological, geological and historical (including biblical quotations) accounts, is not only dizzyingly diverse and blindingly rich, but also fairly one-sided. Every time an adverse piece of observation is reported, such as Spratt's account of a negative movement in western Crete, Suess honestly cites it, but then says that one needs corroboration from further observations and leaves it there. He also expresses surprise that no evidence of fault-related dislocation is known to him that has been related from the numerous accounts of earthquakes along the Mediterranean shores. "Should, however, some example be discovered of a genuine dislocation affecting the Mediterranean coast in bistoric times" he writes at the end of this chapter, "yet this would not invalidate the general result of our comparative study. The Mediterranean region has so far afforded no proof of a secular continental elevation or subsidence within the historic period." (Suess 1888, p. 584; 1906, p. 465; emphasis Suess'). By this time it is clear to his readers that it is really against the former kind of movement that Suess had mustered all the evidence. He will repeat the same great display of data and the clever argumentation in the next two chapters. However, modern research has uncovered abundant evidence of land uplift during earthquakes in the Mediterranean region both during the Holocene and during its historical part (for the most recent review of the evidence, see Boulton and Stewart in press).

The purpose of the next two chapters is also to show that no remarkable change in the position of the shoreline could be established anywhere on the globe during historic times, although Suess confesses that it is difficult to be absolutely certain. That there is a general negative movement in very recent times, he concedes (he will repeat the same conclusion in $\mathrm{v}$. III/2, when he comes to describe the coral islands in the Pacific Ocean). But this is everywhere the same and did not take place during historical times.

The final chapter of volume 2 is a summary of the seas. He repeats the difference between the Pacific and Atlantic type 
margins and indicates that both result from subsidence, with the difference that along the Pacific margins the continents (or island arcs) are thrust onto the ocean, whereas around the Atlantic steep normal faults drop the ocean bottom into the deep. He summarizes the transgressions and regressions and says that while the former develop very slowly and commonly from the equatorial areas northward, the latter are fairly abrupt. He ascribes this difference to the fact that regressions follow oceanic subsidence, whereas transgressions are caused by the filling up with sediment of the space created by subsidence. He calculates that the subsidence of the Aegean and the Black Sea with their satellite basins probably caused a 4 metre drop in world-wide sea-level if it is assumed that when sea water eventually invaded these basins they were entirely empty.

While eustatic movements are held responsible for the major transgression-regression cycles, Suess says that they are not sufficient to explain the finer oscillations of the sea-level seen in the geological record, thus anticipating our modern conclusions as expressed in Bilal Haq's message I quote above. He stresses again the stability of things during historical times and reminds the reader the need for immense time intervals to bring about the great geological changes we see in the record. This is again a plea for the adoption of Lyell's methodology of actualism. He ends on a poetic note about the importance of time and our helplessness in dealing with it:

"The astronomer, in order to render conceivable the immensity of celestial space, points to the parallelism of the stellar rays or to the white clouds of the Milky Way. There is no such means of comparison by which we can illustrate directly the great length of cosmic periods, and we do not even possess a unit with which such periods might be measured. The distance in space of many stars from the earth has been determined; for the distance in time of the latest strand-line on Capri or the last shell-bed on Tromso, we cannot suggest an estimate even in approximate figures. We hold the organic remains of the remote past in our hand and consider their physical structure, but we know not what interval of time separates their epoch from our own; they are like those celestial bodies without parallax, which inform us of their physical constitution by their spectrum, but furnish no clue to their distance. As Rama looks out upon the Ocean, its limits mingling and uniting with heaven on the horizon, and as he ponders whether a path might not be built into the Immeasurable, so we look over the Ocean of time, but nowhere do we see signs of a shore." (Suess 1888, p. 703; 1906, p. 556).

As Rama is considered by the Hindus the representative of perfection despite the trials and tribulations he has to contend with, so the reader cannot help but consider Suess the perfect geologist, even if the reader cannot follow him in all of his struggles with the obstinate sea-levels.

\section{Part IV: The Face of the Earth}

Suess originally planned to wrap up his results in part four of the Antlitz, to present a synthetic view of the 'face of the earth' in his projected v. III. He had done his best in Asia to collect the available information in the two previous volumes. However, as he sat down to write the final part, those magnificent Russian studies along the projected Trans-Siberian Railroad, the legendary Transsibirsky Magistral, began pouring in (for a complete list of these Trudy and their principal results, see:
Comité Géologique de Russie $\{1900\}$; Suess owned a personal copy of this book: see Anonymous 1914, p. 5). As he wrote to the editor of the English translation of the Antlits, William Johnson Sollas (1849-1936) in January of 1904, his earlier studies had shown

"... a number of peripheral, chiefly arc-shaped fragments surrounding a vast and wholly unknown centre situated in Mongolia and Siberia, the exploration of which could alone furnish continuity.

The third volume had already advanced far towards completion within the limits originally proposed when an examination of these very regions was commenced on a large scale preparatory to the construction of the Siberian Railway."

(Suess 1904a, p. vi).

Also, in 1887-1888, the Hungarian aristocrat and sportsman Count Sámuel Teleki de Szék (1845-1916) led an expedition of exploration to East Africa to the totally uncharted territories north of Lake Baringa in Kenya upon the suggestion of the intellectual crown prince Rudolf (1858-1889) and took with him as science officer the ship of the line lieutenant Ludwig Ritter von Höhnel (1857-1942). They mapped the topography of the area all the way to Lake Rudolf, which they discovered and named, and collected rock samples. Their mapping and observations were so detailed and accurate and their collections were so judiciously gathered and abundant that upon their return, Suess suggested that the products of their expedition also be evaluated geologically. The resulting nowclassical memoir of the Academy of Sciences in Vienna included Suess' famous paper announcing the presence of a vast rift valley of extensional origin from Lake Nyasa in the south to the Red Sea in the north (Suess 1891). Suess also wanted to include the geology of the Great Rift Valley in the last part of the Antlitr. As a consequence, the third volume became so long that it was decided to divide it into two: the first, numbered III/1, came out in 1901 and the second, III/2, in 1909.

Volume III/1 may be considered the foundational book for the geology of Asia and the precursor of Argand's La Tectonique de l'Asie (Argand 1924). It also introduced a totally new type of orogenic belt which had remained entirely unappreciated until I drew attention to it in 1991 (Şengör and Okuroğullar1 1991; also see Şengör et al. 1993, 2014a, b; Şengör and Natal'in 1996, 2007).

Volume III/1 consists of nine chapters (for an excellent review of this volume, see de Lapparent 1902). Chapter one is an introduction to the tectonics of Asia. It begins by reminding the reader that on earth two kinds of dislocations are seen: those related to horizontal motions and those resulting from subsidence. Suess says that the magnitude of horizontal motions have turned out to be much greater than originally suspected. In this first part of volume III he concentrates on folding and associated phenomena and in the second part he returns to areas of extensive normal faulting and subsidence. One of the main purposes of this first part is to complete the description of the trend-lines of the world's mountain ranges. Suess will mostly concentrate on the northern hemisphere, because, in the southern, the seas occupy such a large area that a successful synthesis of the trend lines, especially in view of the paucity of available observations, cannot yet be hoped for.

Suess points out that although the distinction between fold 
belt and table-land has been a useful one for his descriptions so far, a closer look blurs the distinction, because, wherever the stratigraphic basement of the table-lands is exposed, it is seen to consist of folded rocks. He thus concludes that during the 'Archean' (he means the Precambrian) folding or some equivalent structures of shortening were universally generated. $\mathrm{He}$ says that at one time the cause of folding was active everywhere on earth and now it is more restricted areally (Suess' brief account of the Archaean should not be understood as implying either synchrony of, or a short time taken by, the universal folding, although he did talk about the uniformity of the trends of Precambrian folds in large areas when discussing the basement of the Russian Table-Land in the last chapter of volume III/1: see below; he simply had no means of subdividing the Precambrian time because no Precambrian biostratigraphy was then possible). In the Antlitz, wherever the term 'Archaean' is used, it means all the crystalline, non-fossiliferous rocks below the Paleozoic rocks. Today it is customary to refer to that part of earth history as Precambrian or Prephanerozoic. The term Archaean was introduced by Dana (1872, p. 253 in the following context and with the following words: "Archæan rocks. - Besides the limestone and Taconic schists and gneiss, there is, near Poughquag, in still more intimate connection with the quartzite, rocks of the Azoic age, a continuation of the Highland range of New Jersey - a range recognized as Azoic first by H. D. Rogers, and shown to continue into Dutchess county by Logan and Hall (this Journal [by which he means the American Journal of Science], II, xxxix, 96). They are probably Laurentian, as stated by Logan and Hall, that is, they are equivalents of the oldest known Azoic rocks of Canada. But as this point is not definitely settled, and since the term Azoic has been ruled out by facts that the era was not throughout destitude of life, I propose to use for the Azoic era and its rocks the general term Archæan (or Arche'an) from the Greek $\alpha \varrho \chi \alpha \iota \varsigma$ pertaining to the beginning." Here Dana added the following footnote: "Whatever part of the Archæan beds are proved to belong to an era in which there was life, will be appropriately styled Archeozoic. This term avoids the objection which Eozoic derives from the doubtful nature of the Eozoum." Dana later discussed the Archaean in detail in the second edition of his Manual of Geology (Dana 1875, p. 146161), which we know for sure that Suess read (from his references to it in Die Entstehung der Alpen: Suess 1875). Thus, the trend-lines he will review are likely to include those of different ages. He says that even different plans of trend-lines may well turn up. The review he so far presented has consisted of fragments and it is this fragmentary nature that makes the whole thing puzzling.

Of the previous review he mentions as areally important the difference between the Atlantic and the Pacific margins. He finds it curious that both the Antilles and the Gibraltar arcs represent mountain belts that turn around as if to avoid entering the Atlantic realm; as if something is stopping them. Suess observes that a similar arc once existed north of Spain, in Asturias and Cantabria. Here occurs, in all the foreign editions, one of the graver errors in translation. Suess wrote (I supply my own translation in square brackets after his German):

"Es ist aber schwer zu verstehen, wie sich eine solche neue Curve bilden soll, wenn nicht irgend eine Art frei anspülender Erdwellen vorausgesetzt werden will." (Suess 1901, p.
8) [But it is difficult to understand how such a new curve can be formed when a kind of free washing up of earth waves is not assumed.]

Hertha Sollas translated it as follows:

"But it is hard to conceive how such a curve could be formed a second time, unless we assume the existence of some kind of wave propagating itself freely through the crust of the earth."

(Suess 1908, p. 4).

The critical German word here is anspiulen, which literally means 'washing up onto something'. Suess clearly implies a décollement under the advancing arcs; there is no implication of waves propagating through the entire crust. To the contrary, only an upper flake moves and gets folded atop an undeformed substratum. This is consistent with his earlier statements, as far back as the Entstehung der Alpen. The very same error in translation recurs in the French and the Spanish versions (Suess 1912, p. 8; 1928, p. 9), possibly influenced by the rendering in English. There are several similar mistranslations in all of the various renderings of the Antlitz into different languages. They occur almost always in the theoretical parts, not in the straightforward descriptions. They collectively show how different was Suess' conception of tectonics from those of his contemporaries. It is easier to understand him now than it was then. To understand him then, one had to have read all of his publications, at least those pertaining to tectonics beginning with his 1868 Wieliczka paper. Very few of his readers even bothered to read the whole of the Antlitz and they paid the dear price of not understanding what he wanted to convey. That was the main cause of the Dark Intermezzo and it is the cause of some of our present regressive steps such as terranology (see Şengör 1990; Şengör and Dewey 1990). Understanding Suess is therefore not only of historical interest; he remains very relevant today.

After having reminded his readers of the importance of the distinction of the Atlantic- and Pacific-type coasts, he points out the similarity of the architecture and the history of construction of the European mountain chains from the early Paleozoic to the present: they show a progression of mountain-building activity to the south while retaining a dominant north vergence. In the case of the Urals and the Caucasus, however, this is not the case: the more southerly Caucasus trends $90^{\circ}$ with respect to the more northerly Urals.

In Asia, the continent is surrounded by mountain arcs, all outward verging with respect to the interior of the continent. Suess says that this disposition is so regular that it begs for a common explanation. To supply such an explanation is the job of the present volume.

Chapter two first repeats the idea that the south- and south-east- and eventually east-convex mountain arcs must betray a common cause and point to the presence of a common vertex in the north. Asia seems to be built from north to south: in the Himalaya, even the younger Cainozoic rocks are folded, whereas north of Lake Baykal, even the early Cambrian sedimentary layers lie flat. Suess recognizes the following main morphotectonic units in Asia: 1) two arcs along the Arctic margin, 2) the vast Siberian plain dominated mainly by taiga and, along its southern periphery, small discontinuous patches of steppe and 3) the great mountain ranges of Asia disposed in numerous concentric arcs.

Suess reserves the discussion of the northern arcs for a 
later place, because the Verkhoyansk arc seems to have definite connection with Alaska. So he starts with the Siberian Plain. The river Yenisey divides this plain into two. In the west, as far west as the Urals, is the great Siberian depression extending from the Porte of Turgay (central Kazakhstan) to the Arctic Ocean. In the east is the Siberian Table-Land which consists mainly of what Suess calls the Amphitheatre of Irkutsk.

The West Siberian Depression is filled with young sedimentary rocks. The oldest Suess can identify in the south are the late Cretaceous sedimentary rocks in the extreme southwestern parts of the depression. They do not extend into the basin (Suess had no means of knowing what much later became known, namely the most widespread transgression during the Tithonian to early Berriasian Jurassic Bazhenov Shale in western Siberia, the world's largest known hydrocarbon source rock, itself locally overlying conformably early and medial Jurassic marine sandstone and shale: see, for example, Ulmishek 2003). During the Eocene, the marine transgression begins in the south and during the early Oligocene it reaches almost as far north as $65^{\circ} \mathrm{N}$ latitude, where its deposits are seen in the valley of the Sos'va south of the town of Beresov. Interestingly, this is where the southernmost traces of a Volgian (=Tithonian) to Cretaceous transgression is also seen, but it cannot be compared with the Cretaceous known from the far southwest. Towards the end of the Oligocene all marine connection through the Porte of Turgay is lost. After this we only have the last, latest Cainozoic, transgression in the north.

The terrain east of the Yenisey is totally different: The sedimentary layers north of Lake Baykal, beginning with the equivalents of the Olenellus shale of the early Cambrian, are flat-lying. Marine conditions continue with much limestone; later, sandstone and even gypsum appear. These sedimentary layers are absolutely flat-lying except around a horseshoeshaped terrain consisting of metamorphic rocks embracing the Siberian Table-Land from the south, where strong folding lasting into the Mesozoic everywhere verges toward the interior of the horseshoe. Suess calls the horseshoe made up of what he believed to be Precambrian metamorphic and igneous rocks the 'Old Vertex' (= Alter Scheitel) and the flat-lying rock area inside it, the 'Amphitheatre of Irkutsk'.

The early Paleozoic marine sedimentary layers in the Amphitheatre are overlain by continental formations with a rich flora. Suess is surprised that this flora is very reminiscent of that which he earlier encountered in the southern continents and which helped him define Gondwana-Land. The ages of these plant-bearing rocks reach from the Permian into the Jurassic, in Japan even into the Cretaceous (Suess probably meant here what are now called the Hokobuchi Group and the Hetonai Formation \{the locality Hetonai is now called Tomiuchi: see Matsumoto 1984, p. 1 \} of Hokkaido: e.g. Uwatoko and Ohtatsume 1933; Matsumoto 1984; and the Kuji and Futaba Grups on Honshu that are deltaic and contain coals: e.g. Okami et al. 1994).

Suess notes that Gondwana-Land was delimited to the north by a wide zone of marine formations of Mesozoic age going from Sumatra and Timor, via Tonkin in northeastern Vietnam, Yunnan in southwestern China, the Himalaya and the Pamirs, Hindukush and all the way into Asia Minor. He says that these deposits are to be seen in their entirety as the remnants of a sea that once lay right across Asia. Suess' beloved son-in-law and colleague in the University, the great paleontologist and certainly one of the greatest of the Viennese Giants in the history of geology, Melchior Neumayr (1845-1890), had called it in 1885 the 'Central Mediterranean' (Neumayr 1885) but Suess will here refer to it as the Tethys, following the terminology he suggested in a short paper published in 1893. "The present European Mediterranean" he wrote, "is a remnant of the Tethys." (Suess 1901, p. 25; 1908, p. 19). Suess sounds here as if he is simply changing the name of a former sea first discovered by his son-in-law eleven years after his early demise. This is not so. Tethys and the Central Mediterranean are not identical objects, although the latter was certainly the inspiration for the former. The Central Mediterranean was a Jurassic seaway that reached from Central America and the Caribbean to Burma. Suess' Tethys was sealed to the west by the Triassic terrestrial deposits around the Gibraltar and in the east it went through almost the whole of Indonesia (Termier 1920 , p. 16, completely misunderstood this point and wrote, supposedly citing Suess, that there was no doubt that the Tethys had crossed the Atlantic Ocean; further evidence that he really never read the Antlitz thoroughly). Moreover, Tethys remained extant from the latest Permian to the Eocene as an ocean similar in structure to the present-day Mediterranean and the Atlantic.

After having mentioned Gondwana-Land and redefined the Tethys for the benefit of the reader, Suess says that he will call the second land-mass located to the north of the Tethys and characterized by the plant-bearing sedimentary rocks he had just described, Angara-Land, after the name of the river near its middle. Finally he delivers the punchline of this section of the chapter:

"The disappearance of the Tethys and the union of the ancient continent of Angara with the Indian fragment of Gondwana-Land gave rise to the existing continent of Asia."

(Suess 1901, p. 26; 1908, p. 20).

Atop the Angara beds are the Mesozoic deposits of the transgressions that entered the Amphitheatre of Irkutsk from the north. There are no Triassic deposits, but Suess mentions the Lias, the Brown Jurassic (i.e. the Middle Jurassic) and the Neocomian. The post-glacial transgression is ubiquitous in northern Asia.

He finally describes the widespread mafic rocks covering almost the whole of the western half of the Amphitheatre of Irkutsk, the famous Siberian Traps, first discovered by the Polish geologist Alexander L. Chekanovsky (1832-1876), while in exile in Siberia because of his participation in the 1863-1864 Polish rebellion. From the uniform heights of the table-lands formed by these extensive rocks, Chekanovsky thought that they all had to be contemporaneous. It was suspected that these immense flows were not created by central volcanoes but came out of fissures. Suess has some difficulty with the asserted contemporaneity of all the mafic flows, because some of the basal Angara beds contain mafic clasts and some of the flows were contemporaneous with Lepidodendron-bearing sedimentary rocks.

Suess calls the folds along the inner margin of the Old Vertex 'marginal folds' ( $=$ Randfalten $)$ and notes the existence of granite intrusions younger than the Paleozoic near them. Paleozoic sedimentary rocks lie flat across mica schist belonging to the Old Vertex. Suess notes that although the Amphitheatre of 
Irkutsk is a subsided continuation of the Old Vertex, the marginal folds show that it was (also?) shortened later. He ends up by expressing his surprise that although a wide Tethys separated Angara-Land from Gondwana-Land, the evolution of their floras appears very similar.

The third chapter of volume III/1 is devoted to a minute description of the Old Vertex. The Old Vertex is the horseshoe shaped area of metamorphic rocks that are older than the Cambrian; Suess refers to them collectively as Archaean, which in his terminology simply means metamorphic Precambrian as I pointed out above. Ivan Chersky (actually Jan Czerski \{18451892\}, another Polish exile to Siberia after the 1863-1864 Polish revolt) called the common strike of the eastern part of the Old Vertex, i.e. the northeasterly strike, 'the Baykal direction' and that of the rocks in the western part, i.e. the northwesterly strike, 'the Sayan direction'. Along the Baykal direction, the old rocks are accompanied by younger igneous rocks, porphyries, porphyrites with tuffs and breccias, melaphyres, basalts and in places trachyte and rhyolite. Suess warns that the young basalt flows are not to be confused with the older and much more widespread Siberian Traps. The younger rocks are accompanied by northeast-striking normal faults. Suess borrows the term the Russian geologists have used to describe them: 'disjunctive lines':

"Finally, in the best-known parts of the mountainous region, and particularly across the lower Selenga, we see undoubted subsidence troughs. Our Russian colleagues describe them by the very expressive term "disjunctive dislocations." Indeed it would be impossible to explain the formation of a series of sub-parallel fractures and troughs, the course of which corresponds for long distances to the strike of the ancient folds, without assuming a certain amount of extension, acting approximately in the orientation of the shortening expressed by the ancient folding. This extension may result in disjunction, i.e., it may give rise to fissures and also to subsidence of long strips of land between these fissures. Eruptive rocks of different ages may then accompany the disjunction." (Suess 1901 , p. 55-56; 1908, p. 41).

In Russian, however, the term 'disjunctive dislocation' simply refers to faults-as opposed to folds that are known as 'plicative dislocations' (e.g. Kosygin 1952, p. 36-40, 1969, p. 110-181; Obrutchev 1959, p. 212-213). Some of Suess' disjunctive dislocations, which he interpreted exclusively as normal faults, are now known to be thrust faults delimiting rampvalley basins formed from the shortening of late Paleozoic rifts (e.g. Turfan: see Allen et al. 1995; Şengör et al. 2014a, b); others are pull-apart basins along Mesozoic and Cainozoic strike-slip faults. He interprets them as grabens that very much follow the strike directions of the older folding. Lake Baykal actually consists of two such grabens and has existed since the medial Cainozoic. Its peculiar fauna migrated into it from the south and east. The faults that delimit the Amphitheatre of Irkutsk against the Old Vertex are old, however, already laid out during the Precambrian, but they were repeatedly reactivated later.

As Suess proceeds westward from the Eastern Sayan Mountains, a part of the Old Vertex, he comes to the Western Sayan and notes that it is a much younger mountain range with a different trend. The rocks in it have two different dominant strikes: northwest in the south, northeast in the north. It has no Precambrian gneiss and no young basalt. The deformation of its rocks is pre-Devonian. He says that the Western Sayan is so completely different from the Eastern Sayan both geographically and geologically that a different name should have been given to it (Russian geographers are yet to respond to Suess' complaint). The rocks west of the Western Sayan Mountains strike generally to the north-northeast and it seems that near the city of Minusinsk there may be a younger vertex.

To the southeast, old rocks enter Mongolia and Suess notes a younger belt of schist embracing older gneiss from the southeast to the south. Wherever rocks are older than the Paleozoic, Suess considers them a part of the Old Vertex. So, much of northern Mongolia is such a part. To the west, in the Valley of the Lakes, there are further disjunctive lines, this time north to north-northeast striking. The older rocks of Mongolia disappear southward and eastward beneath a flat-lying younger cover. These are the Gobi Beds. His informant, the great Russian master of geography and geology of Asia, Vladimir Afanasievich Obruchev (1863-1956) sent Suess a vertebrate fossil fragment from these. Suess himself prepared it (fossil preparation was one of Suess' hobbies, perhaps acquired while he was working in the Hofmineralienkabinett. It was said of him that the more difficult a fossil was to prepare, the more enthusiastically he tackled it) and identified it as a Rhinoceros sp. thus dating the Gobi Beds as Cainozoic (we now know that they span a much longer time interval: the Central Asiatic Expeditions of the American Museum of Natural History discovered in the 1920s that the Gobi series did not form a series, but are made up of continental deposits ranging in age from the early Cretaceous to the present and containing significant stratigraphic breaks spanning different intervals in different basins. The geologists of the Central Asiatic Expedition divided them into fifteen formations. They contain fossils of dinosaurs having yielded the first dinosaur eggs known, Middle Tertiary mammals and mammals that just preceded the Ice Age \{Berkey and Morris 1924, esp. figure 16; 1927, p. 40-41; Andrews 1932, especially chapters IV, XIII, XIV, XV, XVII, XIX, XX, XXV, XXXIII, XXXVI, XXXVII, XXXVIII, XLI\}; additional information concerning Andrews' expeditions is to be gleaned from Gallenkamp 2001: this book has a useful bibliography of Andrews' publications, which are many; see Bausum 2000, for some excellent photographs of Andrews' expeditions and a brief biography of him; for some of the spectacular recent dinosaur finds in these deposits, see Novacek 1996). For a modern geological assessment of these deposits, see Anonymous (1989, chs. 14 through 16) and Anonymous (1991, esp. chs. 11 through 13).

In the fourth chapter, Suess follows the successive ranges striking first northeast and then, as one goes eastward, more and more north. These ranges display younger rocks, Paleozoic and Mesozoic, and they are no longer a part of the Old Vertex. Suess shows that these ranges become younger as one goes eastward. Finally, the Izu-Bonin and the Mariana arcs are the youngest additions. Suess writes that

"In the direction of the Ocean we know of no limit to the wonderful arc-producing power which emanates from the Vertex of Eurasia." (Suess 1901, p. 187; 1908, p. 146).

Suess also notes that none of these chains possess a central axis and they are east- to southeast-vergent. He observes that many long longitudinal fractures disrupt these chains. They are 


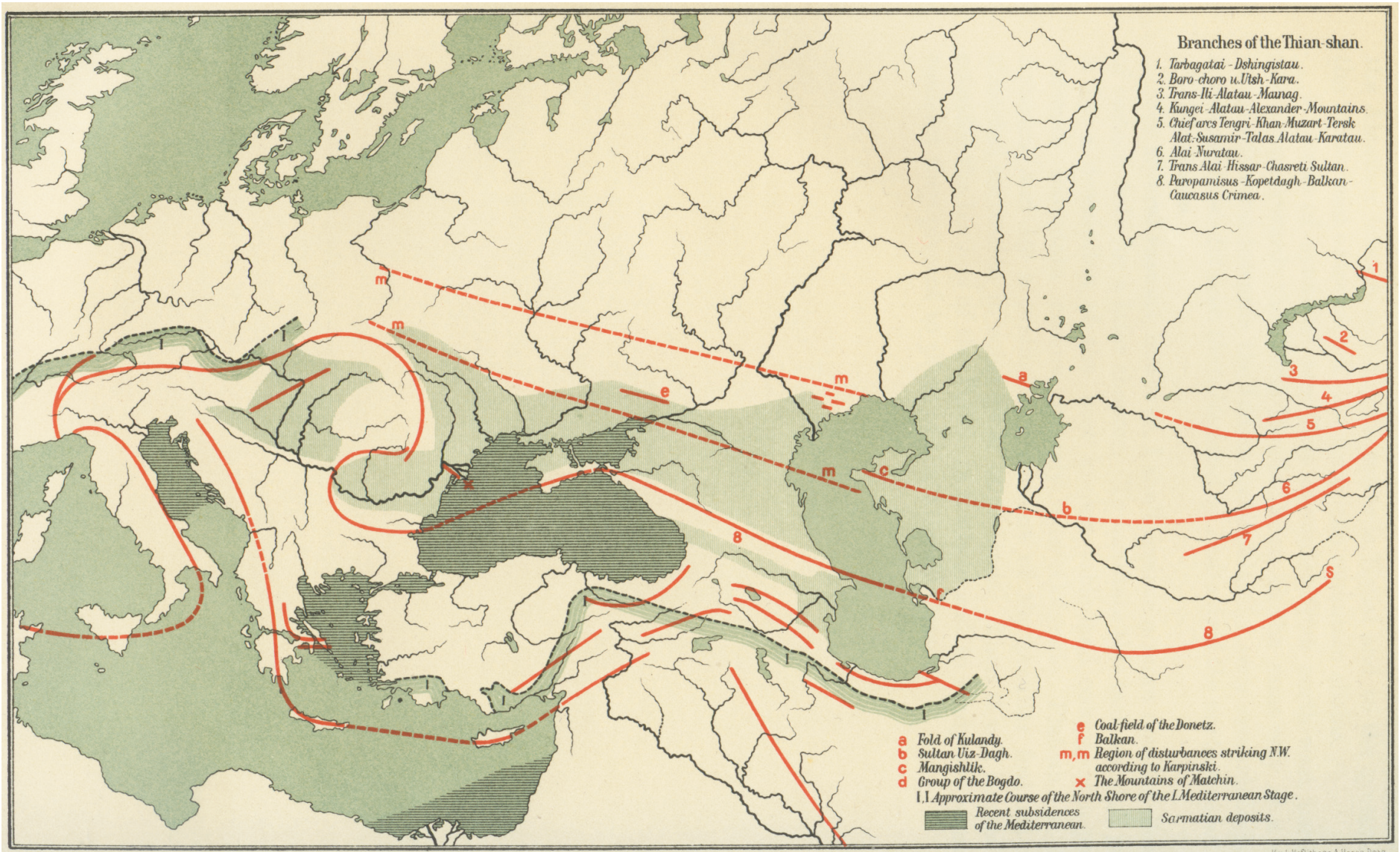

The Relation of Europe to Asia.

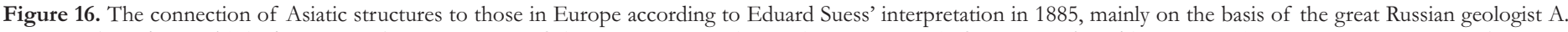

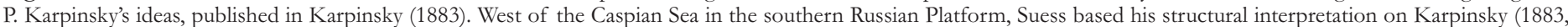

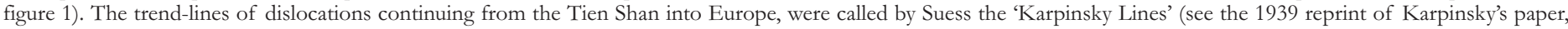

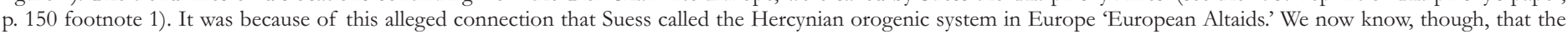

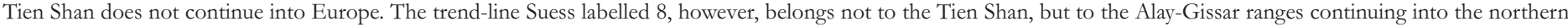

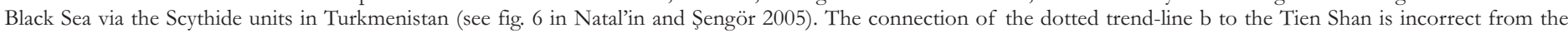

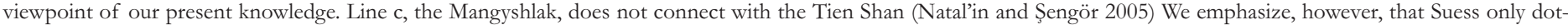

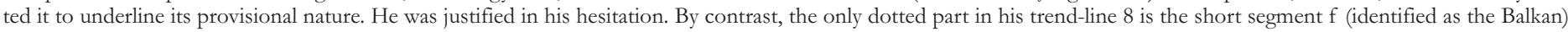
passing south of the lagoon of the Karabugaz Gol in the eastern Caspian Sea.

convex to the east in the same sense as the chains, but their curvature is gentler and, in places, they thus come to cut across the strike of the older structures of shortening in the chains. Suess says that this kind of shortening followed by extension predetermined the strike of the shortening structures during the subsequent posthumous folding. The shortening structures of the posthumous episode follow the strike of the disjunctive structures.

As one approaches the Pacific Ocean, the marine Mesozoic beds make their appearance: the Triassic of the Ussuri River with Pseudomonotis ochotica Keyserling 1848 (now referred to the genus Monotis Bronn 1830); the Middle Jurassic of the coast of the Sea of Okhotsk with the Aucella beds (also defined by Count Keyserling 1848) and traces of Tithonian sedimentary rocks. By contrast, landward, terrestrial beds dominate from the late Carboniferous into the Jurassic. Suess says that land progressively grew westward and he ascribes this to the process of folding. The stable land area in the northern part of Asia, Angara-Land, has played a special role in the evolution of life together with the other such long-sustained land areas. Suess here underlines the influence of tectonics on biological evolution:
"This part of the world affords an exceptional opportunity for determining with some degree of precision the permanence of a continent. In the whole course of the long period represented by the fossiliferous sediments of our planet, the phylogenetic thread of organic life has never been broken, though the process of evolution has to all appearance been neither uniform nor continuous. Changes in the environment must have had a great influence, especially the repeated changes in the extent and boundaries of the ocean. The denizens of $d r y$ land and of fresh water react to these changes in a completely different manner from those of the sea. In the case of the former the uninterrupted continuity of the phylogenetic thread presupposes a long stability of certain places of refuge [in the German original: Asyl, i.e. asylum] which for marine forms of life are never wanting. The extreme conclusions deduced from this principle, correct in itself, together with considerations regarding the great depth of the seas, have led to the doctrine of the universal stability of both continents and oceans, a theory which Nature does not confirm to this extent. In Angara-Land, however, we see a large area of the earth's surface, which from a very remote period has been apt to serve as a place of refuge for terrestrial and freshwater animals; 
under favourable circumstances, new colonies may have radiated outward from it in all directions, as from Linnaeus's island of Paradise. Angara-Land is not the only region of this kind." (Suess 1901, p. 190; 1908, p. 148-149).

With these statements Suess briefly returns to his old interest in the relationships between the outer non-living spheres of the earth and the biosphere. Das Antlitz der Erde will finish with a special chapter on life and here Suess has given us the first hint in the Antlitz concerning his views on the mechanisms of the evolution of life.

Chapters five and six of volume III/1 are among the most important of the entire Antlitz. They are devoted to the description of the Altaids, a concept first introduced here. The importance of these chapters stems from the fact that the Altaids describe a wholly new type of mountain-building one that is areally extensive and one that does not have the narrow, curvilinear aspect of the mountain ranges most geologists are familiar with. The Altaids are not only areally extensive, but their material is also unusual: they have little gneiss, no molasse, but an immense abundance of shale, sandstone, schist, chert, interspersed with serpentinite and basalt, locally intercalated with limestone and in some other places covered by them or by extensive sandstone blankets and in many places intruded by abundant granite. They are disposed in northerly concave arcs, nested one in another, whereby the arc radius becomes ever larger as one goes from the Altay Mountains to the Tien Shan.

Alexander von Humboldt (1769-1859) in his immortal L'Asie Central (de Humboldt 1843) was the first to notice that the Altay and the mountains in northern Kazakhstan were peculiarly poor in gneiss. Suess showed that this was the general characteristic of the entire set of mountains from the Altay to the Kuen-Lun, which he included in the Altaids. Earlier Suess had likened mountain-building to waves breaking on a beach whereby the beach represented the foreland. In the case of the Altaids there were no forelands. Mountain-building proceeded by building arcs after arcs. To the south of these chains were the mountain ranges that had grown out of the Tethys. In chapter seven, Suess pointed out that where the Kuen-Lun met the Tibetan plateau were the northernmost deposits of the Tethys. To the east, the Altaids embraced the whole of China and Suess counted as their member even the currently developing island arc systems of Indonesia. In the east, the Tethys met the Altaids in the Himalaya, where the Tethyan chains were cut off by the Altaid waves coming from the north. The fact that Altaids have no forelands, Suess expressed with the metaphor that in contrast to the chains that resembled waves breaking on a beach, the Altaids were like the waves in the open ocean. It is these waves that built an entire continent around the Old Vertex in the north.

Westward, the Altaids enter Europe through the Karpinsky Lines and via the Greater Caucasus (Fig. 16). The Armorican and the Variscan arcs, together called the Hercynian chain by Suess' great admirer and friend, the French genius of tectonics, Marcel Bertrand in 1887, are parts of the Altaids, but represent backthrusting with respect to the Altaid edifice, because they are north-vergent (Bertrand 1887; Fig. 17).

Backthrusting, or backfolding (Rückfaltung) is a concept Suess had already introduced in volume Ia, p. 181, to account for the south-vergent thrusts in the Southern Alps. It happens in the back of major mountain ranges as a consequence of a spillover of planetary material in regions of shortening. The Randfalten of the Amphitheatre of Irkutsk are also backfolds and backthrusts with respect to the Altaids. In the case of the Hercynian chains, the whole system is one giant backfold/thrust that also extends all the way into the Appalachians and the Ouachitas. Thus, in his scheme, the Appalachians are also a part of the Altaids. The Alps had formed in post-orogenic subsidences that formed along numerous 'disjunctive lines' in Europe within the Hercynian edifice. That is why Suess calls them 'posthumous Altaids'. Disjunctive lines also exist in Asia: in addition to those Suess already described on the Old Vertex, there are many perched on the Altaids locally disrupting their structure and burying them under basins. Many exist in the Tarbagatai Chain and to its north and south. Others are lined up along the Tien Shan and to its north.

Suess says that the Altaids cannot be understood if one takes its individual arcs as independent units, because every arc is stratigraphically, structurally and genetically related to others surrounding it. Modern research has fully corroborated this view of Suess concerning the Altaids (cf. Şengör et al. 1993, 2014a; Şengör and Natal'in 1996, 2007). Where it differs from him is the extent of the Altaids in time and space. Suess considered the Kuen-Lun and the whole of China and Indochina plus the Malay Archipelago as parts of the Altaids, because the Himalaya, a Tethyan chain, seemed to him not to continue eastward structurally but cut off east of Assam by the Burmese and Thai chains coming from the north. Moreover, in the north, he had difficulty finding a boundary between the Altaids proper and the Kuen-Lun/Qin Ling mountain ranges. In contrast, we are now able to follow the Kuen-Lun via the Northern Pamir/Hindu Kush/Paropamisus ranges into the Tethyan system. We also know that the Himalaya is not cut off in the east, but describes another sharp syntaxis and continues into the Burmese ranges. Therefore the Altaids are now confined to the ranges north of the Alay Range, the Tarim Basin and the Nei Mongol Autonomous Region (Inner Mongolia) in the People's Republic of China (all parts of what Şengör and Natal'in 1996, called the 'Intermediary Units' which include their Manchurides) and they do not continue into Europe (for the most recent assessment of the Altaids, see Şengör et al. $2014 \mathrm{a}$ and $\mathrm{b})$.

Suess' view of the Altaids was that they were waves of mountain building that spread concentrically away from the Ancient Vertex of Asia. Wherever they met obstacles, they were deflected building forced virgations and syntaxes. They go as far as the Ouachitas and, as we shall see in volume III/2, Suess considered both the Canadian and the U.S. Rockies as parts of the Altaid edifice, as the farthest 'free ends' of the system. As such, both the Appalachians and the Rocky Mountains were 'backthrusts' embracing as a whole the table-land of Laurentia. The Pacific Ocean, by contrast was a foreland; the Atlantic nothing more than an inner-Altaid and inner Gondwana-Land basin subsided along disjunctive lines. This too comprehensive view of the Altaids is now abandoned, mainly after the recognition that the Tethyan chains showed greater continuity than Suess had then considered. The following quotation from his volume III/1 best illustrates Suess' view of the Altaids: 


\section{EUROPA.}

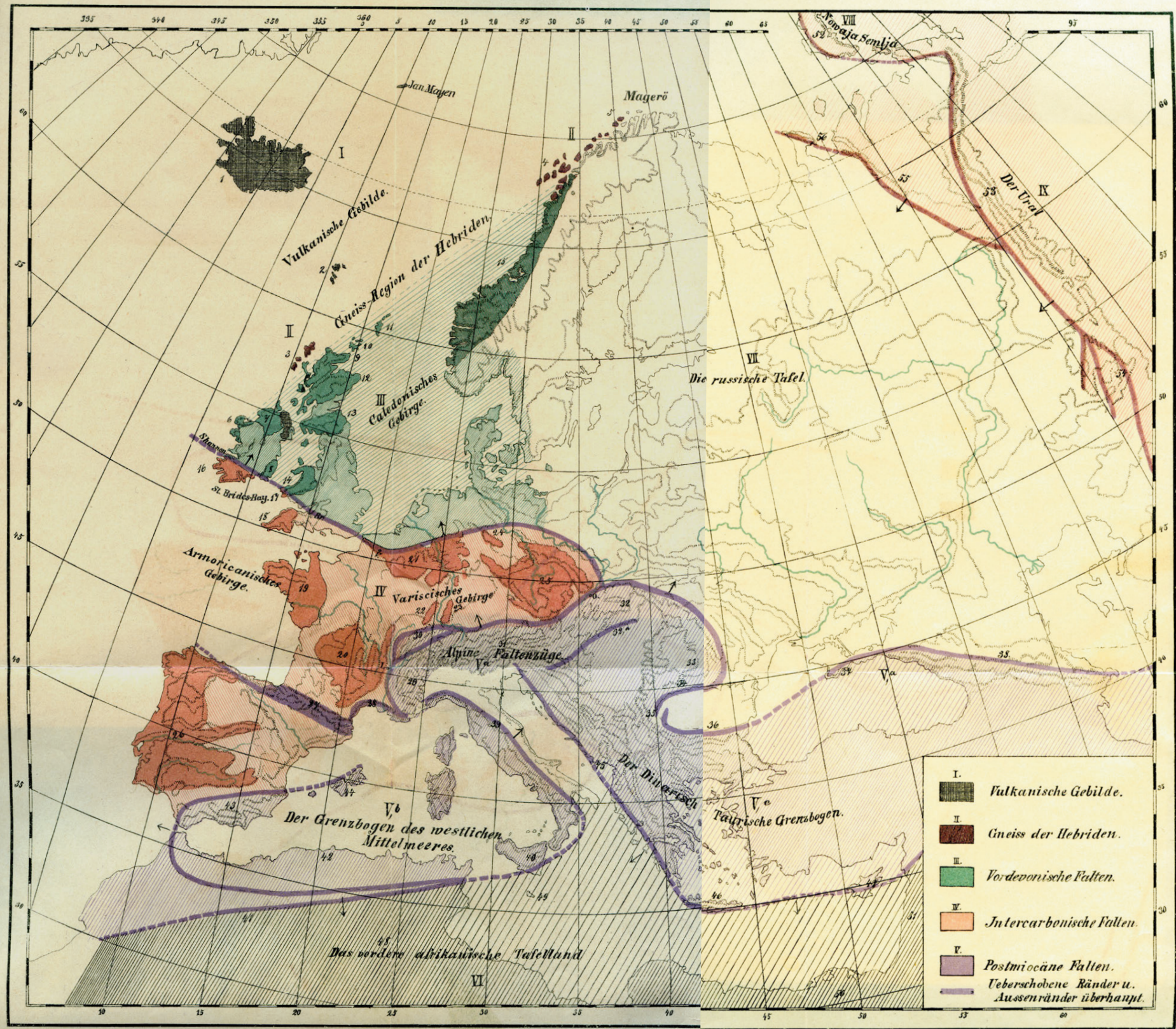

Figure 17. The five-fold division of the geological evolution of Europe: I) Volcanic edifices, II) Gneiss region of the Hebrides (Suess thought it possibly was a part of Laurentia) and the III) Pre-Devonian folds (Caledonian Mountains = Caledonisches Gebirge), IV) Inter-Carboniferous folds (Armorican and Variscan mountains = armorikanisches Gebirge and variscisches Gebirge), V) Post-Miocene folds (= Alpine folded trains = Alpine Faltenəüge, the Dinaric-Tauric marginal arc $=$ Die Dinarisch-Taurische Grenzbogen.) The Russian Table-Land = Die russische Tafel; the frontal African table-land $=$ Das vordere afrikanische Tafelland. Thrust margins and outer margins in general $=$ Ueberschobene Ränder und Aussenränder überhaupt. Copied from Suess (1893b).

"The Altay rises west of the ancient Baykalian vertex and of the intermediate region of Minussinsk, as an independent and younger vertex. Towards the east and south its development has been checked. The most important of its eastern branches, the Kusnetskii Alatau, probably proceeds from the region north of the upper Katun: it passes Lake Teletsk on the east and, describing a gentle arc, reaches the plain east of the town of Tomsk. It is probable that south-east of this branch come other branches, slightly divergent from one another, which extend to the Saksar and the Izykh, near the town of Minussinsk. The quiet exterior region of the Altay describes an arc to the south. In the middle of this arc stand the highest peaks. The western part pres- ents on the Irtysh a north-west strike, but it is not possible to assign a boundary on the south-west to the younger vertex.

In order to obtain an approximate idea of the configuration which is thus developed, let us imagine the whole part of Asia which lies to the south-west to be covered with water. Let an impulse originate from the Irtysh or the Tarbagatai and let us follow its effects towards the south-west. Numerous long mountain waves arise one behind the other; at first they are more or less convex towards the south-west, as in the branches of the Tien-Shan. They broaden out and elongate, or diverge from one another, where they find room enough, as on the Chu and the Ili. They crowd together and rise, towering 
up, where the space grows narrower, as in the Nan Shan. Sometimes they sweep past obstacles, stiff and straight, as in the Qin-Ling-Shan, continually seeking a lateral prolongation; sometimes, on the contrary, they are impeded by these obstacles, bent and turned aside. At first the universally predominent direction is to the north-west or west-north-west. It is these folds or waves that we group together as the Altaids.

In Europe the folded ranges have collapsed, and within the outer frame of horsts new folded ranges have arisen. In Asia, we witness similar events, though on this continent it is not peripheral chains which collapse, but parts of an ancient vertex." (Suess 1901, p. 246-250, emphasis is his; 1908, p. 196-197).

The seventh chapter of volume III/1 is the last chapter of the Antlitz devoted entirely to Asia and it ends by wrapping up Suess' view of the geology of the continent. It begins with the so-called Yarkand arc that connects the middle Kuen-Lun with the Pamirs. Suess points out that its southerly slopes were washed by the northernmost waves of the Tethys. The Yarkand arc dams and obstructs the waves of mountain-building emanating from the Altay. It is thus the natural outer limit of the Altaids here. Anything to the south formed out of the rocks of the Tethys all the way to the Indian subcontinent. The Himalaya is a south- to southwest-vergent chain, as he had said earlier, but he now stresses that it has nappes as large as those now known from the Swiss Alps. Suess describes the strange mixture of marine sedimentary rocks with mafic igneous rocks in the western Himalaya and points out that together they form a nappe that had issued from the north. We now know that he was speaking of the ophiolitic mélanges of the Kiogar Nappe in the Kumaon Himalaya and that his interpretation corresponds exactly to ours today (e.g. Murphy and Yin 2003).

Following a detailed review of the new advances in the geology of what is now Pakistan he points out that here the rocks and the deformation become younger towards the Indian subcontinent. One branch goes down north-south to form the Kirthar ranges, but west of it the ranges bend around to the southwest and eventually to the west. Suess shows that what he had earlier called the Iranian arc is displaced some 8 to 9 degrees of latitude, i.e. almost $1000 \mathrm{~km}$ to the south with respect to western Himalaya.

The Alborz in the north appears as an independent structure, a secondary arc. To the northeast, Suess observes that the southernmost ranges of the Tien Shan enter into the Pamir System, making the central and the western Pamirs a part of it. There is hardly a structural boundary between the Altaids and the mountain ranges born of the Tethys here. However, some branches, such as the Hindu-Kush and the Safed Koh, must be separated by older, Precambrian fragments, as suggested by his countryman Karl Ludolf Griesbach (1847-1907; he was right: the particular fragment here instanced is now called the Farah Block; see Şengör and Natal'in 1996). Suess identifies the northern margin of the Tethys in this place with the ranges of the Hindu-Kush, the central Afghan Ranges (he presents an interesting historical overview to show that the name Paropamisus is actually an obsolete one that should be replaced by Band-i Baba or Barkhat Dagh; nowadays Band-i Turkestan is also used) and the mountains of Horassan (i.e. the Alborz).

A most informative discussion about the nature of the geology in what is today northernmost Iran and Turkmenistan follows. Suess shows that in this area there are a number of independent branches that trend northwest and they are united in a virgation eastward. The low area between the southern margin of the Ust-Yurt Plateau and the Kopet Dagh is identified as a region of subsidence delimited by faults. Mushketov had called this region the Turkmen Graben, Suess reminds his readers.

In Mangyshlak, the marine sedimentary sequences show a transgression that developed during the Jurassic to be interrupted by a sharp regression in the Valanginian. Then the sea transgressed again reaching a maximum extension in late Turonian and Cenomanian. In the Cainozoic Suess carefully describes the gypsum and salt deposits of the region reaching from the Azov Sea to the basin of the Amu Darya and Syr Darya, most of which are equivalents of the Schlier in Wieliczka, i.e. medial Miocene. He points out that $80 \%$ of the sea water must evaporate before gypsum deposition can start. $\mathrm{He}$ reminds us of the aridity of the climate when this evaporite was being laid down. As one is about to begin thinking that this is just regional geology being described for its own sake, the significance of the evaporite is suddenly illuminated by a tectonic discussion which makes the main purpose of this chapter apparent.

Suess indicates that the Tien Shan has an east-west trend, but both north of Nan Shan in the east and north of the Pamir in the west, its branches fan out creating virgations. He emphasizes the remarkable coincidence along the longitude of the Hazara Syntaxis of the western Himalaya with the point at which the spreading branches of the western Tien Shan virgation join the main stem. Suess uses the word 'flow' to describe the deduced motion of the branches of the eastern and the western virgations of the Tien Shan. There is little doubt that this language and his earlier (Suess 1898) and later (Suess 1904b) papers about the flow of continents inspired Taylor's and Argand's syntheses of Asia based on continental drift and flow of the continents dominated by topographic differences. Kober (1923 p. 379-380) also used Suess' concept of flow of rocks at a large scale, but confined it to mountain-belts robbing it of its significance for continental tectonics (smaller scale of flow of rocks had already been emphasized by Albert Heim \{1849-1937\} in his ground-breaking Mechanismus der Gebirgsbildung \{1878a, b; see also Milnes $\{1979\})$.

Between the main branches of western Tien Shan virgation, the intermontane areas are also folded and in very recent times too. Suess shows that in some areas (e.g. Cham-Tagh opposite Kelif and Shirin-Ferhat southwest of Chodjent) the anticlines are still growing along the strike. However, most of these ranges are covered by the evaporites and Suess naturally concludes that the topography here must have risen out of the evaporite basins in very recent times, after the Miocene, and this process is still continuing. The Altaid edifice is literally flowing from the north, forcing the Tethyan ranges to the south to fold, bend around the Indian obstacle and rise. As one goes west of the northern projection of the Indian obstacle, mountain-building becomes less intense.

But Suess is not quite finished with the evaporites yet. The last section of the chapter seven is subtitled the present-day Asia'. He first says that Asiatic folds do not enter Europe only along the Kopet Dagh-Balchan-Caucasus (i.e. the Greater Cau- 
casus), but that there really is no natural boundary between eastern and western Eurasia. Despite this, however, the present Asia forms such an immense unit especially for all branches of organisms that it is worth taking a look at its present state. Suess reminds his reader that Alexander von Humboldt (de Humboldt, 1843) tried to do this using the mountains of Asia, Ferdinand von Richthofen on the basis of the plains (reference here is to the first volume of von Richthofen's immortal classic China in which the brilliant geographer attempted to define the central parts of Asia as opposed to its peripheral regions: 1877) and Mushketov by emphasizing the late connection of the Aralo-Caspian depression with the Yarkand Region (in the first volume of his Turkestan: Mushketov 1886). But now, Suess says, we know a lot more about the geology of the continent, so that we can do more with its geological history.

He first separates the areas that send their waters to the ocean (exorheic regions) from those that do not (endorheic regions). He then reminds the reader that Ferdinand von Richthofen had used this separation to demarcate peripheral areas of a continent from its central region. Suess couples the peripheral-central duality with another one: coal versus salt. All areas that send their waters to the ocean generate coal; all those that do not end up depositing salt.

In Asia all the ancient regions are in a peripheral position: the middle of Angara-Land in the north, the 'Sinian' block in the east and the Indian subcontinent in the south. All these areas have ancient basements, have been land areas since the Paleozoic and possess a well-developed mature drainage today. In the west, the situation is not so simple. Until the Oligocene, the regions between Iran and the Porte of Turgay were in a peripheral position, because they faced an arm of the sea that extended from the Tethys into the Arctic Ocean. After the Oligocene the seas retreated and these areas became central and, with that switch, began depositing salt and gypsum.

I would like to note that this concept of salt being deposited in areas far from the sea in 'central' regions following orogenies has in fact found its employment in plate tectonics under the designation 'closing salt' referring to the salt deposits forming in molasse basins following a continental collision leading to a local regression (cf. Burke and Șengör 1986, p. 50). Closing salts are those that Suess correctly placed in endorheic regions. 'Opening salts' are those that are precipitated in rift basins that are episodically flooded by sea water, such as those in the South Atlantic (Burke and Şengör 1988). In Suess' world they had their equivalents in the salts of the Red Sea.

By emphasizing that in Asia all old areas are on the periphery, Suess implicitly falsified the 'ideal continent' model of the Americans that had been born with Dana (1863), who had assumed that a continent would have all of its ancient parts in the centre and all the younger areas around the periphery. This 'ideal' continent had been naturally the product of a very parochial view, confined to North America, and Suess, by emphasizing the presence of the opposite situation in Asia, criticized it indirectly replacing a regularistic interpretation with one that is less so, in his ever gentlemanly way.

In the structure and history of Asia Suess distinguishes the following elements in succession: the oldest elements: the Old Vertex with the Cambrian platform of the Amphitheatre of
Irkutsk constituting the Siberian Table-Land, the Sinian nucleus extending from Ordos to Korea and the Indian subcontinent as a fragment of Gondwana-Land. Then the Yarkand Arc against which the Altaids are dammed.

"Finally, the younger Vertex with the Altaids, which in the east as in the west meet the Yarkand arc in syntaxis, and at the same time continue to extend themselves farther; in the east streaming forth as far as the virgation of the Philippines and the Banda Sea, in the west opening out in the virgation of the Tien Shan and penetrating into Europe, in the southeast merging into the Burman arc, and in the south-west uniting somewhat closely with the Iranian arc. Between the two regions which are separated by the horst of India, and as a continuation of the Yarkand arc, rises the Himalaya." (Suess 1901, p. 394; 1908, p. 315).

One thus obtains a picture of a continent flowing southward, creating arcs that are deflected and crowded behind obstacles and open up where their flow is uninhibited. In these mountain systems and the intervening plains areas, Suess distinguishes four principal types of sediment: 1) normal marine formations; 2) evaporite deposits; 3) lacustrine deposits; 4) desert formations. He then points out that the distribution of the first three is dependent on the morphology of the substratum onto which the depositing water body has transgressed and that, he observes, is influenced by mountain-building. The desert deposits are not similarly delimited. In the ancient land masses, if sediments are deposited in basins of subsidence, they then show a complete indifference to the previous outlines of mountain structures. However, the trends of disjunctive lines, between which basins subside, are influenced by the trends of previous folding.

Suess ends the chapter by reminding his reader that he has not yet discussed the Taymyr and the Verkhoyansk arcs.

The purpose of chapter eight is to show why and how the Dinarides, which Suess considers an Asiatic element in the belly of Europe, is to be separated from the Alps proper. To that end, he begins in eastern Turkey and points out that a mighty Taurus arc embraces Asia Minor to the south. He had said as much in volume I, but now he has newer information through the publications of Edmund Naumann (1854-1927) who had just returned from Japan having fathered the Japanese geology in the Meiji Period by occasionally beating up his pupils and, at least once, a subordinate. Naumann had been sent to Anatolia after his return from Japan by the German company building the Bagdad Railroad and was asked to assess how suitable Anatolia would be as a possible German colony in the future.

Naumann distinguished two Pontic arcs: one between Batumi and Sinop and the other from Sinop to the west of Constantinople (present Istanbul). The eastern arc was entirely covered with volcanic rocks. The western arc had a peculiar structure consisting of the Amasra-Heraclea coal basin (now called the Zonguldak coal basin) in its middle where the Carboniferous coal seams were folded along northeast-southwest axes, but they were also chopped up by similarly striking faults that also affected Upper Cretaceous rocks, so that Suess could not be sure whether the folding of the Carboniferous rocks were due to dragging along post-Cretaceous faults. Also the Eocene seemed flat-lying wherever encountered on this arc. In the north Suess came to think that the 'arc' did not have much 
of an arc-like structure. Only farther south, along the valley of the Sakarya River (ancient Sangarios), Suess could see evidence of the western Pontic arc; but here doubts arose whether the curved structures may not be the innermost parts of the southerly Tauride arc.

A third arc in the structure of Asia Minor, according to Naumann, was the broad Tauride arc and it seemed to meet another, more westerly one, at a syntaxis almost along the western shores of Asia Minor. From there westwards all the way to the Southern Alps lay the Dinaric arc and Suess noted that the recent downfaulting of the Aegean Basin had taken place entirely within the Dinaric arc.

Suess followed what he called the Dinarides all along the Adriatic coast, but noted that they crossed the Sea and even reached the Italian peninsula. He pointed to a northwesttrending anticline forming Mt. Gargano (formed from Malm to Albian platform and platform margin carbonate rocks overlain by Upper Cretaceous to Paleocene slope and basin carbonate rocks: for the current interpretation, no different from Suess', see Billi et al. 2007, fig. 3) and said that the city of Venice probably lay entirely within the Dinarides. The Dinarides, therefore, cut obliquely across the Adriatic Sea and reemerged as the Southern Alps in northeastern Italy.

When the reader reaches this point in the chapter, it becomes clear why Suess has laid so much emphasis on a careful description of the tectonics of the Dinarides. From here onwards his descriptions become even more detailed with a view to documenting the presence of a tonalite/granite train that goes from the Adamello intrusion all the way to the Bacher Mountains in the east, near the preset Austrian/Slovenian frontier (these bodies are still known as the peri-Adriatic intrusions or magmatic bodies after Salomon's 1897 designation, which Suess cites on his p. 423; Salomon had sent him an offprint: Anonymous 1914, p. 54). This train of intrusions are young, Cretaceous or even Cainozoic Suess writes, because he can bracket them between the Gosau deposits of Cretaceous age (now known to reach from Turonian-Coniacian to Lower Eocene) and the andesite of the Smrekouz Mountains along the Styria/Carinthia border (which Suess had personally studied \{Suess 1868b $\}$ and also sent samples to Felix Kreuz \{1844$1910\}$ for a petrographic study. Kreutz identified the rock as augite andesite $\{$ Kreuz 1877\}) that is older than the Aquitanian and younger than the Oligocene Castelgomberto beds (now known as the Calcareniti di Castelgomberto of Lower Oligocene age: e.g. Nebelsick et al. 2013). They are parallel with, but north of a major line of dislocation, a scar ('Narbe' Suess calls it; this designation will be taken over by Leopold Kober later to designate a line separating the two oppositely verging flanks of a single orogen as opposed to Suess' usage of it for a line separating two entirely different mountain systems; Stille took over Kober's concept but changed Narbe to Scheitel $=$ Vertex using another Suessian concept; Stille's choice was more appropriate, because a Scheitel for Suess was a place from which the folds emanated and verged away) that goes from the Judicarian Line to the Puster, Gail and the Drau (= Drava) valleys. The intrusions follow this line of major dislocation for $420 \mathrm{~km}$. Suess also says that despite the many similarities, the Triassic facies north and south of that line show significant differences. This major line of dislocation, intrusion and facies difference is therefore the boundary between the Dinarides and the Alps proper. When one considers what one has read so far in the Antlity, it becomes clear that the Dinarides for Suess are nothing but a direct continuation of the major, south-vergent Asiatic arcs. They are the synthetic elements of an Asiatic structure, whereas everything north of them in Europe is antithetic, representing grand backthrusting phenomena with respect to the Altaids and the Asiatic Tethyan elements.

Suess further observes that the Carnic Alps, between the Alps proper and the Dinarides in northwestern Italy and southeastern Austria is an independent element of 'Variscan age' (Suess 1901, p. 433; 1908, p. 346) with a northerly vergence. Suess points out that a major Upper Carboniferous transgressive cover seals the earlier structures not only in the Carnic Alps, but in many parts of the Dinarides.

He winds up the eighth chapter by reviewing the young movements that have created the thrust faults along the Periadriatic lines verging towards the Adriatic Sea.

The final and the ninth chapter of volume III/2 brings the discussions on the tectonics of Eurasia to an interim conclusion, because in the next volume the structure of the Alps will be discussed not only because of the new discoveries (especially that of the far-travelled nappes and the general acceptance of the nappe theory during the ninth international geological congress in Vienna in 1903), but also because of his point that the Alps are posthumous Altaids.

In chapter nine we encounter the view that the Urals are also a posthumous mountain range, not with respect to the Altaids, but with respect to the folds of the Old Vertex. To reach this conclusion Suess first reviews the geology of the Urals by reminding his readers that he had already touched on the subject earlier. In this chapter he makes a renewed attempt to find a connection with the Tien Shan. He first shows that southwards the structure of the Urals shows a southerly opening fan-shaped arrangement. The easternmost visible branch (he emphasizes that a real eastern boundary of the Ural is invisible because of the younger cover) veers to the southeast, goes to south of the town of Orsk and finally disappears beneath the desert, where the oldest visible rocks are Cretaceous in age (with Protocardium billanum [now Cardium (Protocardium) billanum Sowerby 1813 of Upper Cretaceous age: see Basse 1932] he writes). "Hence", he continues, "it is not impossible that one of the branches of the Tien-Shan is deflected into connection with the ranges of the Urals, which diverge from each other towards the south; it may even be regarded as probable, but under existing circumstances it cannot be directly proved." (Suess 1901, p. 457; 1908, p. 361). He was a careful and honest man!

Demonstration of a connection with the Greater Caucasus proved even more elusive. The plateau of Ufa is a buttress that dams the Ural folds, which diverge into a virgation south of it (Fig. 18). Suess was able to follow some folding down to the bend in the Volga and beyond, but not much farther. The Greater Caucasus, he wrote, was a continuation of the Tien Shan.

In the north, the Urals have a number of arcs attaching to them from the west: the Timan and the Pai-Khoi (= 'Stony Ridge' in Nenets, improperly also known as 'Samoyed' language) plus the Novaya Zemlya (= 'New Land' in Russian). He thought the arrangement of the arcs of eastern Asia is similar, but the fact that the sea covers whatever is between the East Asian arcs made comparison difficult. 
Figure 18. The forced virgation of the Uralides. (Suess' own sketch in the unnumbered plate in Suess, 1924).

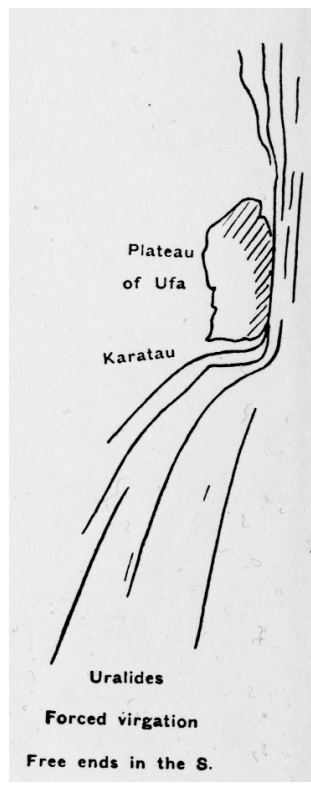

After the Urals, Suess turns his attention to the Russian Table-Land. In the north, from Finland all the way to the Kola Peninsula, there are three packages in the architecture of the Baltic Shield, distinguished by Jakob Johannes Sederholm (1863-1934) in Finland (during his famous mapping program that had begun in 1899; Suess was in communication with him): the youngest ones were grouped under the designation Jotnian: it is barely folded and lies unconformably on the older ones. The next older is the Jatunian; this is considered equivalent to the Algonkian of Charles Doolittle Walcott (1850-1927; of the Burgess Shale fossils fame; he coined Algonkian in 1889 which eventually came to be equivalent to the Proterozoic before becoming obsolete). Below that are finally Archean rocks consisting of granite and gneiss, in which Sederholm was to coin the term migmatite in 1907.

In these rocks the predominant strike was observed to be north-south to northwest-southeast, turning to the northeast in the extreme north. Suess noted the parallelism with the Ural, although he emphasized that these rocks were much older.

Farther south, north of the Sea of Azov there are other outcrops of the basement of the Russian Table-Land (the present Voronezh Shield) and the rocks seem to be the same as those observed in the north. Here the strike is again roughly north-south to northwest-southeast. Suess finally says that the entire basement of the Russian Table-Land is a part of the Old Vertex and its rocks all show the 'Sayan direction' of the Old Vertex. He remarks that old rocks have remarkably constant strike directions, in contrast to the younger ones (Do we here see a faint influence of von Humboldt's loxodromal strike directions in both hemispheres? Suess makes no allusion to them, but see de Humboldt 1823).

As to the Urals, they seem to him to be posthumous Vertex folds, because the Old Vertex surrounds them and shows a similar strike in its rocks. Suess thinks that the Old Vertex is continuous across the Urals, but has subsided to great depths east of it under the West Siberian Plain. Nonetheless, he also points out that some of the scattered outcrops in the Kazakh Steppes do not show the Uralian direction (they are now known to belong to the Altaids: see S.engör et al. 1993, 2014a; Şengör and Natal'in 1996).
To the west, the Baltic Shield is cut off by the Caledonian overthrusts in Scandinavia. After one crosses the glint (i.e. the contact between the Baltic Shield and its Phanerozoic cover), one sees that the Paleozoic rocks, up to the Silurian, are covered by vast masses of metamorphic rocks of the Seve Group very similar to those of the Shield. The great Swedish geologist Alfred Elis Törnebohm (1838-1911) interpreted the Seve Group as entirely allochthonous and Suess agrees. He follows the same allochthonous front all the way to the north of the Scandinavian Peninsula and quotes Per Holmquist's (18661946) view that the Baltic Shield underthrusts the Scandinavian Caledonides at least as far west as the longitude of the North Sea shores. He illustrates Holmquist's remarkable drawings showing what is an earlier version of Ampferer and Hammer's (1911) Verschluckung, a concept the earliest harbinger of which had been introduced by the Rogers brothers in the Valley and Ridge province of the Southern Appalachians already in 1843 as 'swallowing of the stratigraphy' (Rogers and Rogers 1843 , p. 496; p. 616 of the reprint edition) It is a sort of continental subduction, which the Swiss petroleum geologist Albert W. Bally (b. 1925) called A-subduction (A stands for Ampferer; for a more detailed discussion of Holmquist's ideas, see Şengör 1977). Suess also notes that the north-vergent thrusts in Scotland are not a continuation of the Scandinavian Caledonian thrusts. The latter find their continuation in the Southern Uplands and Central Ireland.

He concludes the volume by pointing out that the whole of Eurasia contains in the north the Old Vertex, with the Ural in the middle as posthumous folds. A very large part of the Old Vertex is now covered by the sediments of the Ob' River. To the south are the Altaids and to the south of those are what he termed the marginal arcs. Northwesternmost Eurasia no longer belongs to the Altaids: that part consists of the Caledonides, an independent system. Suess points out that the Altaids do not stop in western Eurasia, but continue into North America which will be treated in the last volume of his book. That is probably why, in the Spanish edition, the third volume brings the book to the end not of the ninth, but of the fifteenth chapter, where Suess finishes Eurasia by presenting the Alps as posthumous Altaids after having considered the Altaids in America (Suess 1928).

The final volume of the Antlits, numbered III/2, opens with a very significant sentence: "Nearly the whole of Europe is a part of the Asiatic structure." (Suess 1909a, p. 1; 1909b, p. 1). Its significance does not stem from the fact it mentions both Europe and Asia, but from the fact that Suess here introduces the concept of the 'Asiatic structure'. In northwestern Europe its western boundary is the Caledonian disturbance. Beyond it, the Hebrides and the other Atlantic islands such as Iceland, Jan Mayen and the Faroes belong to a foreign, Atlantic element, but the whole of the Appalachians and southern Ireland are still parts of the Asiatic structure all the way into Oklahoma and west Texas (comprising the Ouachitas and the Glass Mountains). In the south, the fragmented elements of Gondwana-Land are buttressed against the Asiatic structure. But the Atlas Mountains of Northwest Africa are still Altaid and thus parts of the Asiatic structure. In the east, the boundary is beyond the island festoons of the western Pacific, but the Asiatic structure swings north through Alaska and goes along the eastern border of the North American Cordillera forming the Saint Elias and the Rocky Mountains. It thus embraces Lau- 
rentia on both sides. In both places Laurentia is a hinterland to the Asiatic structure but overridden by its backthrusts, although Suess in an inexplicable manner keeps calling it foreland as I shall discuss below. The Arctic Ocean forms the boundary in the north.

The purpose of the tenth chapter (the first in volume III/2) is to discuss, again, the entry of the Altaids into Europe. In the first footnote of this chapter Suess points out that Marcel Bertrand's Hercynian and his own Altaids signify two different things. He says that so far in the Antlitr. two Asiatic elements in Europe were discussed: the Dinarides and the Russian Table-Land (this is not entirely true: in volume II, there was an extensive discussion of what is today called Hercynides or Variscides in Europe, which Suess will attach to the Altaids in volume III/2; perhaps he meant to say that in the fourth part of the book carrying the same title as the entire work he had discussed only two parts of the Asiatic structure in Europe, namely the Dinarides and the Russian Table-Land ). Here, he follows the Altaids westward along the Donetz structure and farther south and repeats his earlier observation, first published in 1886, that in Europe the regions deformed by folding at different times are sharply separated from one another in contrast to the situation in Asia: the north-vergent pre-Permian folds lie in the north and the currently deforming Alpides, also north-vergent, are found to their south. Suess expresses some surprise because both the Timan and the Dinarides are south-vergent. Only the bit in between, his Armorican and the Variscan arcs and the Alpides are north-vergent. In these north-vergent chains Suess points out the existence of postCarboniferous basins such as the London and Paris basins, or that of the Aquitaine, that are bounded by faults not everywhere following the Altaid structures, but cross-cutting them. These basins were filled with sediment during the Mesozoic and were deformed during the Cainozoic by being compressed between 'rigefied' (i.e. stiffened) frames formed by the intervening horsts. Suess says that the Alps represent the most spectacular example of such a compressed post-Carboniferous basin. An interesting point concerns when the shortening of the Alps actually commenced: on p. 6 and 7 (in the English edition, p. 6) Suess writes: "The Alpine foldings have been preceded or accompanied by subsidence, which, judging from the evidence afforded by the Radiolarian rocks, must have amounted during the Jurassic to at least 4,000 metres." The possibility that shortening might have accompanied subsidence in the Alps, as the reader might recognize, was the starting point of Argand's embryotectonics (Argand 1916), although it contradicts an earlier statement made by Suess in Die Entstehung der Alpen (Suess 1875, p. 6465). All these younger regions of shortening that originated in the post-Altaid basins of subsidence in Europe, but also along the margins of the Atlantic Ocean, such as the young fold belt north of Spain and the south-vergent mini fold and thrust belt in the Serra de Arrábida in Portugal, Suess called 'posthumous Altaids' (p. 3 in both the original and the English editions). The Alpides are their most important member. He even considered whether the folding seen within the Tauern fenster in the Alps may have been a secondary framed folding following the formation of the fenster (the presence of the Tauern fenster as a fenster opened into the immense body of the Austroalpine nappes, he fully acknowledged in contrast to most Austrian geologists of the time).
Already in this first chapter of the final volume we encounter two new, critical, ideas: the idea of 'rigefaction' and the idea of framed folding both of which will play critical roles in the tectonic theories of all the pre-plate tectonic theoreticians of the twentieth century. In plate tectonics their relevance has not been diminished. Although the idea of rigefaction (Erstarrung) had been mentioned already in Die Entstehung der Alpen (but once: p. 160), much more extensive use is made of it in the Antlitz under a modified interpretation of its meaning (see especially, Suess 1909a, p. 720-721; 1909b, p. 625-626). The idea of framed folding may be seen as a belated concession to Élie de Beaumont's simile of the vice. It is indeed, but in a completely new tectonic framework that eventually led to continental drift: in his epoch-making La Tectonique de l'Asie Argand stated:

"The idea of framed folding, whose first glimmering is very old and which has become in the interpretations of Suess one of the subtle aspects of his work and one of the highest achievements of classical tectonics, leads me to my last hypothesis.

I propose to show that the idea of framed folding is capable of such a general applicability that the mobilist theory itself, through its fundamental postulates and in spite of some appearances to the contrary, is really a particular case of it." (Argand 1924, p. 324, emphasis Argand's).

Suess returned to a review of the Asia-Europe connection along the Altaids following the Alay-Turkestan MountainsMalguzar Range-Nuratau-Sheih Deli [a part of Sultan-Uiz Dagh]-Mangyshlak-the coal mountains in the Donetz line, forming one of Karpinsky's lines (Fig. 16). South of them is the so-called Azov Horst lying between the Donetz structure and its northwesterly continuation and the Eastern Carpathian thrusts. Farther south the Greater Caucasus is one member in the Asia-Europe connection. Suess is puzzled as to how the Mesozoic of the Greater Caucasus can be so different from that in the Trans-Caucasus. He conjectures that the southward thrust of the former must be of very considerable magnitude (we know now that the Paleo-Tethyan suture is located between the Greater Caucasus and the Trans-Caucasus: see Şengör et al. 1988).

He follows the Caucasus into the Crimea. There is then an interruption represented by the Bulgarian Plate (the present Moesian Platform). The Balkan Mountains are a north-vergent chain and go around the bend completely to the east of the Bulgarian Plate to form the Southern and then the Eastern Carpathians (Fig. 14). South of the Southern Carpathians, Suess notes the presence of a considerable foredeep. To the southeast of the southeasternmost elbow of the Carpathians is a narrow plain separating them from the North Dobrudja. Here Suess notes the presence of an element foreign to the Azov Horst, to the Carpathians and to the Bulgarian Plate. It is the Cimmerian Mountains, an appellation Suess borrows from the great Romanian geologist Professor Ludovic Mrazek (1867-1944; who in 1910 also coined the term 'diapir') which show northward vergence and deformation involving the Triassic in pre-Jurassic times. Suess notes that there is nothing like it in the rest of Europe except a group of crystalline green rocks in Bukovina cropping out between the Carpathians and the Azov Horst. He thinks these green rocks are the equivalents of the mafic rocks of the North Dobrudja bulldozed and metamorphosed by the Carpathian nappes. 
Chapter ten deals with the entry of the Altaids into Europe from Asia and presents the justification for considering the Alpides as posthumous Altaids. Chapter eleven takes the Altaids out of Europe and follows them across the Atlantic Ocean all the way down to east Texas. Chapter eleven begins with the western margin of the Massif Central and the Armorican Peninsula. Suess here describes the young folding of the northern margin of the Aquitaine Basin and ascribes it to the effects of the Pyrenean deformation to the south. In the Armorican area the Paleozoic is mostly eroded, in contrast to the English and Welsh occurrences farther north, and what remains is clenched along narrow, fault-bounded depressions within metamorphic rocks. Suess surmises that the Armorican area must have once been topographically higher than the British regions to the north and what we see now are mostly the eroded lower levels. Suess notes that in these narrow, faultbounded basins one can see evidence for more than one episode of folding. When followed westward, they subside along younger faults and disappear from view beneath Mesozoic layers. But these Mesozoic layers are also folded. The upstanding 'horsts' such as the Armorican Peninsula, Massif Central and the Paleozoic areas of Lorraine provide the 'frames' within which the Mesozoic sedimentary rocks have been folded. Suess says the folds of the Paris and the London basins have the same relationship to their surrounding horsts as the Alps to their frame. They are the same sort of structures as the Alps, but more open than the highly compressed Alps.

When Suess turns his face to the Atlantic Ocean, he sees that a very wide mountain range abruptly stops at the shore. He compares the European late Paleozoic chains with Tibet and Himalaya and says that it is impossible for such an immense mountain range to stop so abruptly, repeating Marcel Bertrand's observation in 1887. Suess quotes him that the European late Precambrian and Paleozoic chains cross the Atlantic and reappear in North America. He expresses his complete agreement with Bertrand. To support that, he goes into the bathymetry of the North Atlantic Ocean and interprets the data as supporting Bertrand's trend-lines.

Suess then follows the distribution of the Old Red Sandstone from eastern North America to the British Isles. The Old Red Sandstone itself does not reach farther south, but fishes characteristic of it are found in Thuringia and as far southeast as the Donetz region. Suess calls the continent characterized by the Old Red Sandstone and its fossils Eria (Suess 1909a, p. 63; 1909b, p. 59), after the Devonian Erian Flora of Sir John William Dawson (1820-1899). Stille first mistakenly thought Eria was synonymous with Suess' Laurentia (Stille 1928), but later called Suess' Eria Laurussia (Stille 1940a, p. 63), which he had earlier called Laurentofennia (Stille 1928). Lately, Laurussia again has become popular although now some refer to it as the 'Old Red Continent', but the paleobotanists prefer 'Eurameria'. (It is unclear to me why these numerous newer appellations were needed when Eria is a perfectly apposite and succinct designation with priority! One is strengthened in the conviction how little and carelessly Suess must have been read by his successors, even by those who quoted him.) The northern margin of the Altaids in Suess' sense (i.e. the Hercynides in Europe and the Appalachians in north America) thus follows the southern rim of Eria.

Suess then follows the Carboniferous deposits along the same margin and notes that everywhere the Lower Carboniferous is still in marine facies, which however changes into a land facies with coal seams during the late Carboniferous. $\mathrm{He}$ remarks that it looks as if the onslaught of the Variscan, Armorican and Appalachian folds drove the sea out of these areas. Along the Appalachians three zones of very different characteristics are to be noted: in the west, the Laurentian geology from the Long Range Peninsula in Newfoundland to the south. The main body of the mountains is the next zone to the southeast and which is then skirted by a Mesozoic apron bordering the Atlantic. That apron turns to the west and then northwest and delimits the Appalachians to the south. Suess shows that as far west as west Texas (Llano Estacado) the Mesozoic deposits overlie what he calls Atlantic-type sedimentary sequences, but with the Llano Estacado, Pacific-type, west-dipping marine Permian is seen under the later Mesozoic sequences. He follows the Pacific-type sediments north into Oklahoma and Kansas, where, he points out, only their fossils are recognizable as 'Pacific-type'. The Jurassic farther north is terrestrial and carries the fossils of immense reptiles in Othniel Charles Marsh's (1831-1899) 'Atlantosaurus-Beds' (Marsh 1877, p. 516; Marsh had originally considered them Cretaceous, but later realized that they were Jurassic: Schuchert and LeVene 1940, p. 366; they are now part of the Morrison Formation first named by George Homans Eldridge \{1854-1905\} in Emmons et al. 1896, p. 51-151, but first published by Whitman Cross as 'Morrison beds' in 1894; Marsh's Atlantosaurus beds are now roughly equivalent to the lower two thirds of the Morrison and known as Atlantosaurus clays, although Atlantosaurus itself remains a nomen dubium; for an aquarelle of the type locality of the Atlantosaurus beds by Arthur Lakes \{1844-1917\} made in 1879, see Ostrom and McIntosh 1966, p. 15, fig. 5; for a photograph of the same locality, see the large panoramic foldout numbered as p. 49 in the same book; in Schuchert and LeVene 1940, p. 366, text and footnote 14, there seems to be an error concerning the first reference to the Atlantosaurus beds by Marsh). Suess follows this stratigraphy just to show the lateral extent of various sedimentary layers in the marine record with a view to emphasizing the eustatic character of some of the most widespread breaks in the record, as shown by the Potomac plants (Lower Cretaceous) in the Lakota beds in the Black Hills in South Dakota (the Lakota beds are also visible in Lakes' aquarelle).

Suess then returns to the south, crosses the Mississippi and follows the easterly continuations of the Appalachians. In the first Annual Report of the Geological Survey of Arkansas in 1888, the state geologist John Casper Branner (1850-1922; he later became the second president of Stanford University in California) reported the surprising occurrence of an east-west striking, north-vergent mountain belt involving Carboniferous flysch which was unconformably covered by the redbeds of the Permian. Branner called these mountains the Ouachitas. No earlier map had given even the rough topography of them correctly. There arose disagreement as to whether this new mountain range was a continuation of the Appalachians or, because of its somewhat more northerly lie than the southern end of the Appalachians, perhaps one of the Cincinnati Arch. The new mountain continued westward towards the Arbuckle Mountains and then farther to the northwest into the Wichitas. Another branch appeared between the Rio Grande and the 
Pecos in the south where folded Cretaceous was seen. Suess interpreted all these as the southernmost free ends of the Altaids. Although he noted that the mountains west of the Ouachitas were 'divided into horsts', the fundamental tectonic difference between the Ouachitas and the Arbuckle and Wichita ranges seems to have escaped him; at least, he did not emphasize it.

At the end of chapter eleven, Suess summarized his findings: he underlined the great similarity between the late Paleozoic mountain-building events and the associated facies in Europe with those of eastern North America. It was clear that a connection between the Appalachians and the Armorican mountain ranges existed. Towards the free ends the folding lasted into more recent times, an experience, Suess says, corroborating observations in other mountain ranges. To the east of the Appalachians, the Triassic and the Jurassic are still terrestrial and only during the early Cretaceous (Potomac) an Atlantic margin can be identified with as yet a terrestrial margin. Only with the Senonian a major marine transgression signals the presence of open ocean to the east and south. Thus, Suess not only established in this chapter the westerly extension of the Asiatic structure, but also the age of the North Atlantic Ocean, which he fixed as Senonian.

The short chapter twelve is entitled 'the African Altaids', but really deals with the whole of North Africa and complements the account he had earlier given in volume Ib. First Suess discusses the presence of a medial to late Cretaceous seaway from the mouth of the River Niger to the Tethys. Surprising in this regard is the evidence for a Miocene to later seaway from Senegal all the way to Timbuktu (for a map, see Suess 1911b, p. 667, fig. 133) as shown by the two gastropod fossils Marginella egouen (later Marginella (Egouena) appalachee Gardner 1947; now recombined with Prunum (Microspira) appalachee by Woodring 1970) and Columbella mercatoria (although both in dwarfed forms). No modern study corroborated the presence of marine deposits in these areas after the Thanetian (except very near the Atlantic coast) and the two fossils may either be dwarfed forms that adapted to brackish or even freshwater habitats or simply misidentifications (Dr. Didier Merle of Muséum National d'Histoire Naturelle in Paris thinks they must be misidentifications: written communication via Dr. Şevket Şen, 1st October, 2014).

Suess then turns his attention to the central Sahara and notes that in the basement north-south strike dominates. This basement was reported to be older than the Upper Silurian and Suess uses the designation Saharian Caledonides or Saharides following a suggestion communicated to him in a letter by the French geologist René Chudeau (1864-1921). But he is cautious: he remarks that the unconformity may be older. His caution was well-justified: in 1922, the unfortunate but brilliant Conrad Kilian (1898-1950) inferred in a note of only two-anda quarter pages that the Saharides were older than the Upper Silurian because of a thick sandstone sequence under the fossiliferous Silurian (Kilian 1922; also see 1925, p. 65-68 and the figure facing p. 66; for Kilian himself, see Boissonnade 1971 and Lelubre 1992); today we know that Suess' Saharides are of Neoproterozoic in age and call them Pan-African chains.

The Paleozoic marine sedimentary sequences reach into the Lower Carboniferous and there are no rocks belonging to the Permian, Triassic, Jurassic and the Neocomian in the cen- tral Sahara. Under typical Cenomanian rocks there is a sequence of varicoloured claystone and gypsum with fish and dinosaur fossils. Then comes the marine Cenomanian. Suess leaves the Sahara after a brief mention of its young volcanoes.

He starts the description of what he calls the African Altaids by the initial report by George Barthélemy Médéric Flamand (1861-1919) of a scientific mission he undertook to the Algerian Sahara from $8^{\text {th }}$ November 1899 to $24^{\text {th }}$ February 1900. In this report Flamand announced, for the first time, the presence in North Africa of late Paleozoic ('Hercynian' he added in parentheses: see Flamand 1900, p. 242) mountain building. Suess then goes farther south than the southern limit of the High Atlas at Jebel Melias. It is there a completely different world of Paleozoic folds that first strike southwest. Farther to the west, the strike turns south-southwest and then southeast again. Suess follows these Paleozoic foldings into the Atlas all the way to Casablanca and Rabat. Although farther east the geology is not nearly so clear, he says that the presence of pre-Permian mountain ranges here in northwestern Africa is well-established. He suspects the presence of pre-Permian mountain-building as far southwest as in Mauritania. More than half a century later Jean Sougy (b. 1927) showed in 1962 that Suess was right in his suspicion.

Chapters thirteen and fourteen are devoted to the Alps, the western and the eastern, respectively. Suess begins by reminding his readers that the Alpine ranges, called the Alpides, lie framed within the east-west striking Altaids placed between two submeridionally striking mountain systems: the Caledonides in the north and the Saharides in the south. Suess points out further that from the North Pole to the Cape of Good Hope, the Alpides represent the only place where there was large-scale post-Permian folding (he means shortening in general) at high angles to a given meridian. Despite that, Suess emphasizes, there are free ends both toward the east (in the Balkans, in the easternmost anticlines of the Jura in Switzerland) and toward the west (in the Balearic Islands). With this remark Suess underlines the relatively small amount of tangential shortening across the meridians during the Cainozoic. He then points to Asia and says that the Dinarides as a whole moved north to shorten the Alpides. He calls the Dinarides the hinterland of the Alps as opposed to a foreland. Anybody familiar with Argand's great syntheses (Argand 1916, 1924) cannot, at this point, fail to detect Suess' immediate influence on them. All Argand did was to put what Suess said into the framework of Wegener's theory of continental drift.

After these introductory remarks Suess begins to review the recent developments in the Alps. First, he presents a twoand-a-half page summary of the history of investigations. This is not a history for history's sake, but a lesson on how to do geology. The great progress occurred after the Alpine workers had gone over from inductive to synthetic work emphasizing genetic units instead of just descriptive ones. First, an overall architecture of the outer parts of the Alps was established and the dominance of folding was replaced by those of fractures in the form of faults dipping towards the interior of the chain; this reversed a trend that had begun by Arnold Escher von der Linth, but instead of the vertical fractures that had been supposed before him, the new ones discovered were all thrust faults. Then the trend-lines of the Alps were connected with their neighbouring ranges and the inde- 
pendence of the Dinarides was recognized. In 1884 came the great breakthrough of the recognition of the presence of immense nappes in the Alpine edifice by Marcel Bertrand. This was followed by the recognition that the external massifs were nothing more than the extensions of the European foreland under the external parts of the Alps. In 1891, Suess' student and later colleague Carl Diener (1862-1928), one of the Viennese Giants, recognized the distinctiveness of the Briançonnais Zone in the Western Alps with a sedimentary content going from the Carboniferous to the Eocene with very few crystalline rocks and a fan-shaped cross-sectional structure (Diener 1891, p. 12). In the east, the idea of the total allochthony of the entire $480 \mathrm{~km}$ strike length of the Northern Calcareous Alps was proposed. The Tauern was recognized as a tectonic window under the giant crystalline nappes of the Eastern Alps. The Simplon Tunnel brought to view immense, northerly-vergent recumbent folds in the core of the Alps. The schistes lustrés, formerly thought especially by Italian geologists to be Paleozoic in age (their calcschisti), even Precambrian, turned out to be Mesozoic, in accordance with the older views of the French geologists, if not even Cainozoic in some of their parts! Suess writes that his summary appears at a time of increased enthusiasm under the influence of the new ideas. New work was pouring in and different parts of the Alps were becoming known at different paces.

It is impossible to read Suess' summary without recognizing between his passionate lines the great satisfaction of seeing his ideas triumphant. He was conspicuously quiet about the considerable opposition still raging against these new ideas, especially in his own country. We all know that this silence was well-justified: the 'autochthonist' opposition was soon to be thrown into the rubbish bin of the falsified opinions in the history of science.

Following the historical/philosophical prelude, Suess presents a basic tectonic subdivision of the Alps which corresponds more or less to the one still in use: the southern Alps are separated as parts of the Dinarides from the rest of the main body (the Southern Alps and the Dinarides are today separated by some on the basis of the direction of nappe transport and age of deformation along different directions; e.g. Handy et al. 2015). Then the eastern and western Alps are divided along a line in eastern Switzerland corresponding to the giant lower nappe contact of the Austroalpine mass. Finally, the Helvetic nappes, together with the external massifs they overwhelmed, are separated from those of the Piemonte, which Suess was to call the Lepontine Alps. Following Argand, we now call these last the Pennine nappes. The Molasse is a unified foreland trough fill and the Jura is a separate branch of the most external zone of the Alps joining the Helvetic Nappes in the west (where the latter are called the Dauphiné or the Dauphiny or Delphinian nappes).

Suess begins the discussion of the Alps with what he calls the Zone of Mt Blanc corresponding to the external massifs of Mercantour, Pelvoux, Grandes-Rousses, Belledonne, Mont Blanc, Gotthard and Aar. He notes that their internal structure is not exactly parallel with their margins, but maintains a strike more northwesterly in the west and more northeasterly especially in the more northerly massifs. In the more northerly massifs, the internal structures of these massifs are also parallel with the strike of the Variscan structures of the foreland.
Suess warns against regarding these massifs as Variscan horsts. He underlines that they belong to the Alpine structures truncating Variscan trends. He also noticed that the sedimentary nappes are dammed against these massifs where the nappes behave like a fluid flowing around the massifs. Fold axes are deflected around the edges of the external massifs and trend deviations of up to $90^{\circ}$ are not uncommon. Suess says that the massifs behave like barrages for these nappes. Nobody who has read Argand's 1912 paper on the tectonic segmentation of the Western Alps, where he compares the massifs to the pylons of bridges and the deflection and mounting of the nappes behind them with the rise of a flowing river behind the pylons, can fail to see Suess' direct influence on this paper, which eventually led to the two great syntheses of the Alps (Argand 1916) and of Asia (Argand 1924, 1928). One wonders whether Argand's pylons (piles in French: Argand 1912, p. 347) were the source of the pilar for Horst in the Spanish translation of the Antlit?? We in fact learn from the very scholarly Diccionario de Geología y Ciencias Afines edited by Pedro de Novo y F. Chicarro, the translator of the Antlitzinto Spanish, that the word pilar was derived from pila, i. e., stack in Spanish, from the same root as in French (de Novo y F. Chicarro 1957, p. 1509)!

Suess then reviews the geology of Diener's Briançonnais Zone. His main point here is that the fan-shaped cross-section, previously held to be a result of vertical uplift, is now recognized to be a consequence of lateral shortening. Suess considers the Briançonnais a part of his Piemonte subdivision (our Pennine nappes). It lies between two strips of flysch, the outer of which reaches into the Oligocene. In the west are the schistes lustrés. These two correspond to the sediments of our Valais and Piemonte oceans (see Trümpy 1960, for an excellent modern stratigraphic review and 1976 for the still current tectonic interpretation).

Suess next deals with what he calls Deckschollen. This is a direct translation of Marcel Bertrand's (1884) lambeaux de recouvrement and thus a tribute to him (lambeau is scrap in English and thus refers to remnants of former nappes left behind by erosion). One can translate it into English as outliers or klippen; indeed Percy George Hamnall Boswell (1886-1960) translated Deckschollen as depicted by Franz Heritsch (1927, fig. 3; Heritsch's dates are 1882-1945), which Heritsch had copied and translated from Maurice Lugeon's (1870-1953) lambeaux de recouvrement (Lugeon 1903, fig. 1 and p. 17) as nappe-cake or klippe (Heritsch 1929, p. 14, fig. 3). But in the context of the text we are here discussing it would be wrong to translate Deckscholle only as outlier or klippe, because Suess here discusses not only the outliers of both the Penninic and the Helvetic sedimentary nappes, but also those that are still attached to their roots, although this was not exactly the original sense in which Bertrand had used the term (Bertrand 1884). But Suess' usage of Deckschollen not only paid tribute to Bertrand, but also extended the meaning of the German term to complete nappes. No wonder Maurice Lugeon (1870-1953) used the French word nappe (= cover, sheet) instead of lambeau in his great classic that led to the acceptance of the nappe theory internationally (Lugeon 1901). For example, when Viktor Uhlig (1857-1911; another Suess pupil and one of the Viennese Giants; Uhlig became Suess' successor in the University of Vienna, but unfortunately died young) wanted to mention what we today call the nappe theory, he wrote Deckschollentheo- 
rie (Uhlig 1903, p. 770). Thus nappe became the international term and not lambeau. In German, Decke alone is now used; it is an exact translation of nappe. In the Antlitz, Suess also used the term Decke, when the literature he used employed Nappe (see, for example, Suess 1909a, p. 263; Sollas translated Suess' Decke as sheet: Suess 1909b, e.g. p. 237-238: note how little the international terminology relating to nappes had as yet stabilized). Klippe, meaning crag or cliff in German, had been originally used in the sense of crags protruding from a gentler landscape of a different rock composition. In geology, very early, Klippe had come to mean both nappe remnants floating on a foreign substratum and exotic blocks within a matrix of a different composition. The former became known as 'Swisstype' and the latter as 'Carpathian-type' klippen. Already in the second part of the volume I of the Antlitr, Suess felt the need to make this distinction (Suess 1885, p. 558).

In the English translation of the Antlits, Sollas rendered Suess' Deckschollen with 'recumbent sheets' (Suess 1909b, p. 114). In the French edition, Emmanuel de Margerie appropriately used lambeaux de recouvrement (Suess 1911b, p. 708) In the Spanish translation they are called hojas de cobijadura (i.e. cover sheets: Suess 1928, p. 521), which is an excellent translation both of the original lambeaux de recouvrement and Suess' Deckschollen.

Suess begins the description of the nappes in the south and first presents the Penninic nappes between the massifs of Mercantour-Argentera and Pelvoux. Here he notes how between the two massifs the nappes shot far to the west and he compares this motion again with the motion of water through an opening in a dam and with the movement of glaciers between two nunataks. This is a comparison he had published earlier (Suess 1904b), but now he refers to two earlier figures he had published in 1888 to illustrate his comparison with actual cases; Figs. 19 and 20).

When we read Suess' comparison of nappes with glaciers and water, we have to remember that he was writing at a time when not only the reality of nappes was being questioned, but also it was being claimed that mechanics would not permit their motion. In 1909, Marian Ritter von Smolan Smoluchowski (1872-1917), professor of physics in the University of Lemberg (now Lviv in Ukraine) and co-discoverer of the Brownian motion with Einstein, supported Suess' simile with a short, but important paper (Smoluchowski 1909). Despite this two-page paper, with no equations, arguments against the possibility of nappe movement raged in geology for many years and did much harm to our understanding of the structure and evolution of mountain belts, although Suess' suggestion was later reinvented by Sir Harold Jeffreys (1931; also see 1935 where the arguments and figures of the 1931 paper are reproduced), followed by Walter H. Bucher (1956a, b, 1963), who also remained ignorant of Suess' model (although he cites Plate 20 from the last volume of the Antlitz showing cracks in asphalt, indicating clearly that he has seen, but not read the book) it is surprising how late it became generally known. Hubbert and Rubey (1959), in a paper considered classical, do not even cite Suess. Ignorance of Suess' work during the Dark Intermezzo is indeed quite shocking.

Suess then follows what we call the Pennine units behind the Belledone Massif and then describes how they again overwhelm the external massifs and shoot far to the north to form

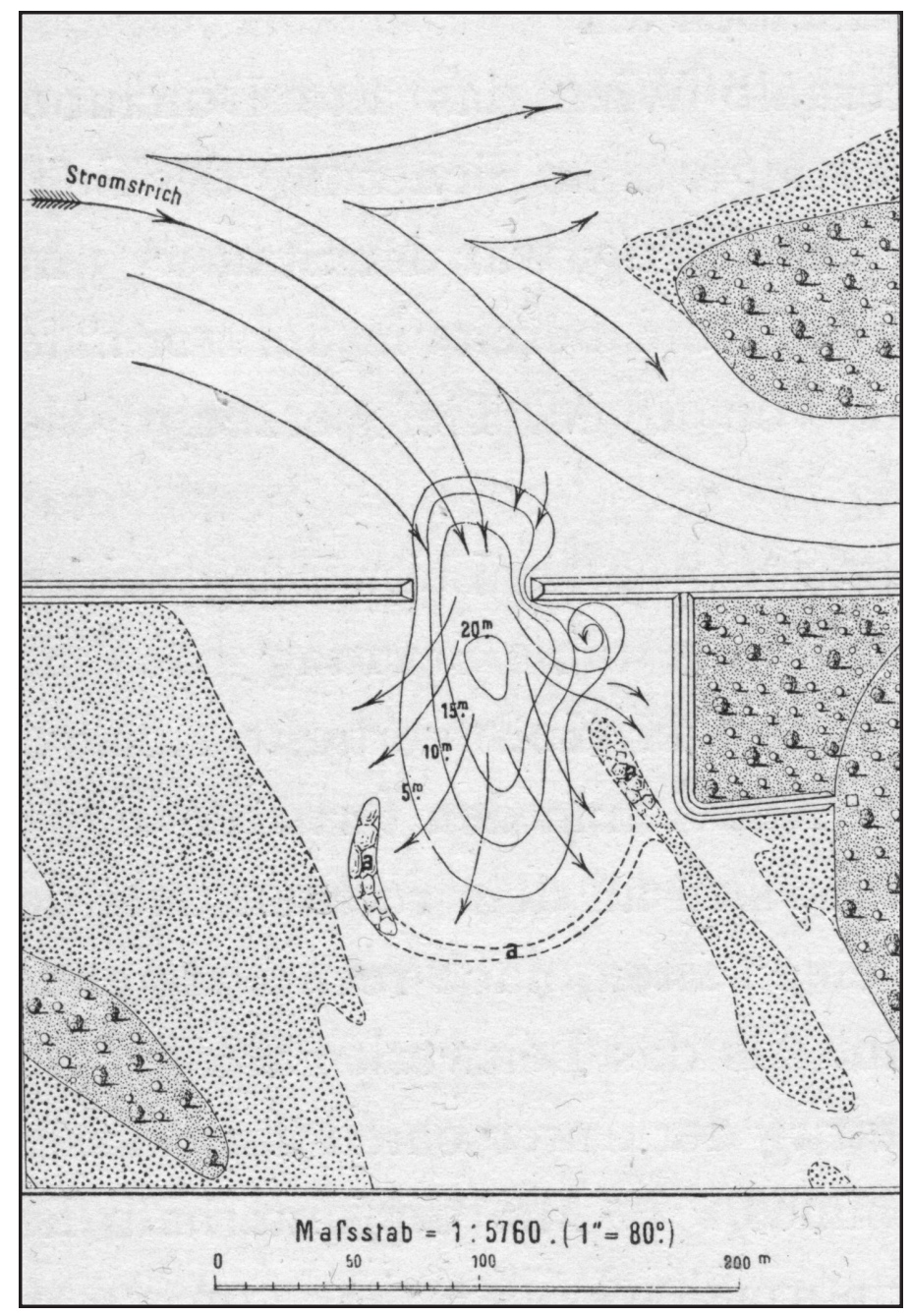

Figure 19. Closure of the Neu-Haufen dyke, Schüttau. a,a,a horseshoe-like mound of large blocks of stone, torn from the foundation of the dam and swept along out of the colk. The mound is lowest in the middle owing to the activity of the current. Suess compared the movement of the water out of the opening in the dyke with the movement of the Pennine nappes between the external massifs of the Alps. (From Suess 1888, p. 436, fig. 35; 1906, p. 343).

the Préalpes of Chablais and Stockhorn. He points out that the smaller klippen to the east from the Mythen to Iberg are the representatives of the equivalent units thrust far to the north. He will return to their equivalents farther east later.

Suess describes the Glarus nappes in some detail. His emphasis here is the existence of a number of nappes piled on top of one another, all once having been surmounted by the Pennine units coming from farther south and all transported to the north with respect to the foreland.

Having finished the Glarus nappes, he returns to the Penninic units and describes the magnificent Simplon profile, drawn along the famous, nearly $20 \mathrm{~km}$-long tunnel that had opened on the 10th May, 1906, sent to him by Hans Schardt (1858-1931), the discoverer of the Prealpine nappes (or perhaps one should say the corroborator, because Bertrand had already suggested that they were allochthonous in his prophetic 1884 paper!). Using these results and their own mapping Lugeon and Argand had recognized seven crystalline nappes with metamorphosed sedimentary synclines in between, all north-vergent, betraying an immense amount of horizontal shortening. Despite certain objections from the side of some 


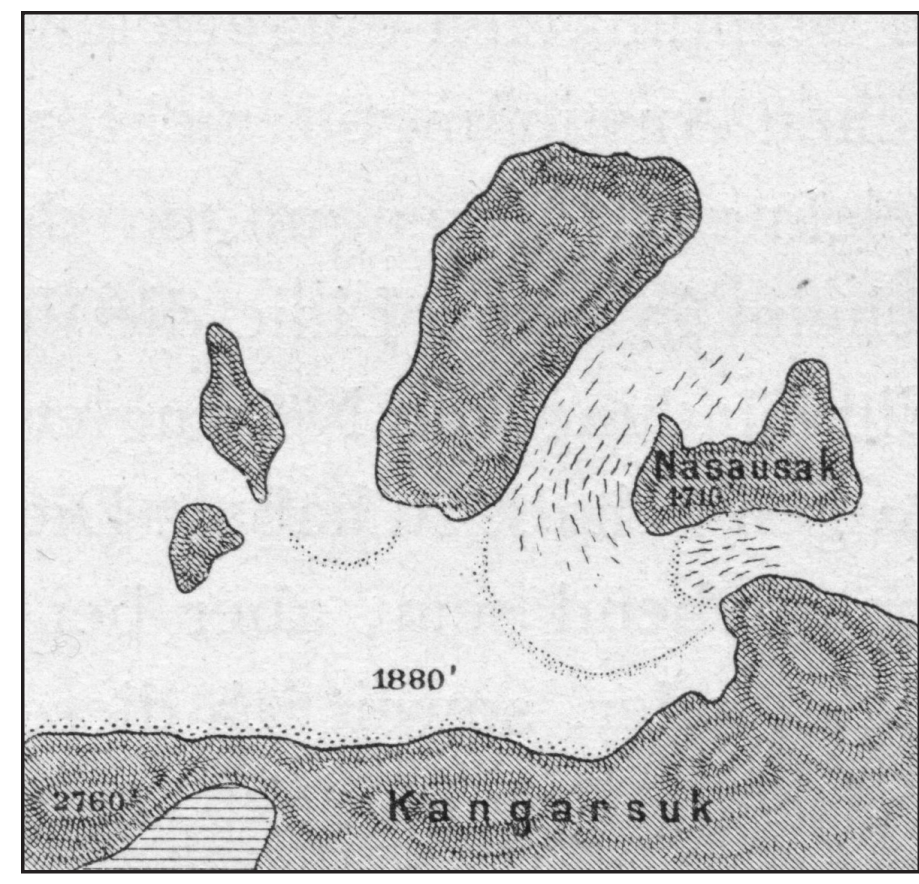

Figure 20. Dalager's nunataks. Notice the two moraine lobes indicating the oozing out of the glacier between the two nunataks. Suess compared the movement of the ice between the nunataks with the movement of the Pennine nappes between the external massifs of the Alps. (From Suess 1888, p. 437, fig. 36; 1906, p. 344).

Italian geologists, Suess agrees entirely with his Swiss colleagues.

Going farther south, Suess comes to the extremely complicated zone of the Ivrea. In those days, the Sesia-Lanzo Zone was considered a part of the Ivrea and to the northeast of the Sesia-Lanzo Zone a second part of the Ivrea was assumed (Ivrea II). The dioritic-kinzigitic parts of the Sesia-Lanzo zone, Suess regards as contact metamorphic rocks. The mafic/ultramafic rocks of the Ivrea he regards as sills intruded along surfaces of least resistance, in many places along the original bedding. He follows Argand in considering the greenstones of the Dent Blanche nappe equivalents of the Ivrea. For him they are truly 'Alpine' rocks and are to be separated from the Dinarides (i.e. from the Southern Alps), although Carl Schmidt (18621923) had considered the Ivrea mafic and ultramafic rocks much older and separate from the greenstones of the Dent Blanche. It turns out that both interpretations were correct (see Ernst and Dal Piaz 1978).

From the Western Alps, Suess proceeds to their southern continuation. He first deals with Corsica and Sardinia. He points out that they must be viewed as a single unit and calls that unit Corsardinia. The Triassic developed in two different facies on Corsardinia: by far the greatest part resembles that on the European foreland, i.e. it is Germanotype, that is to say epicontinental terrestrial to shallow water lagoonal, but that in northeastern Corsica has an Alpine (or Mediterranean, i.e. continental margin to oceanic) facies. Where there is Germanotype Triassic, the basement was deformed before the late Carboniferous. Suess considers much of Corsardinia a southsoutheast trending branch of the Altaids. The younger area of deformation, Suess sees as a continuation of the Pennine (in his terminology Piemontese) Zone of the Alps. Even the tiny Tyrrhenian islands of Gorgona and Pianosa between Corsardinia and the Italian mainland are described. Gorgona resem- bles northeast Corsica, Pianosa is a Pliocene table-land. The others are like Elba and thus are parts of the main trunk of the Apennines.

In the Apennines, Suess recognizes the continuation of the Piemontese Zone (i.e. the Pennines) in the Ligurian mountains which he says 'is a horst-like cutaway'. In it Steinmann recognized two main nappes: a higher one with greenstones like the ones on Elba and a lower one without them. For Suess, the island of Elba shows the connection between the Alps and the Apennines. The Apennines are northeast-vergent, but in the north become north-vergent. Near Torino one sees its last external folds representing a young free branch showing in what direction the folding dies out.

Chapter thirteen is a masterful summary of the recent research on the Alps; but it is more than that: here we see the importance of the flow of rocks in generating nappes, a fecund idea that had to be reinvented a number of times decades later. We also see the documentation of the continuity of the trend-lines from the Alps to the Apennines and to Corsardinia. What this chapter says is not all that different from what we read in the current literature more than a century later minus continental drift.

Chapter fourteen is devoted to the Eastern Alps, Suess' home ground, and he says the aims of the research here are different from those in the Western Alps. The Eastern Alps are more extensive, there are no equivalents of the ultramafic rocks of the Ivrea Zone. Instead there are tonalitic and granodioritic intrusions and at the eastern extreme andesite (there is a reference here: III, p. 422, fig. 17, which can refer to no place in the Antlitz. Suess should have written "III/1, p. 422 and fig. 17 on p. 442").

Suess first describes what he calls the Lepontine Nappes. These are the highly deformed and metamorphosed parts of his Piemontesian Nappes, i.e. our Pennine nappes. He notes that they dive under the Austroalpine units in eastern Switzerland. The nappe of the greenstones is so highly deformed that its magmatic rocks are dismembered into blocks (Steinmann 1905 , p. 10, had called it a Reibungsbrekzie, i.e. a friction breccia. Suess refers to Steinmann. The 'friction breccia' is what is today known as the Aroser Schuppenzone: a mélange unit: Cadisch et al. 1919; see Şengör 2003). Thus, almost the entire Alps of Switzerland were once covered by the higher Pennine Nappes. They thus sit in a tectonic half window today (Suess 1909a, p. 172-173).

In the Eastern Alps Suess discusses the three windows of the Tauern (discovered in 1903 by the great French geologist and a friend of Suess' Pierre Termier \{1859-1930\}: 1903), the Lower Engadin (indicated by Termier 1903, plate 23; corroborated by Suess 1905), and the Semmering (the Antlitz, is the first place where the tectonic window character of the Semmering rocks is mentioned, see Suess 1909a, p. 174 and 176, 1909b, p. 157 and 160; although the presence of Mesozoic rocks in it had already been discovered in the $19^{\text {th }}$ century: see the excellent summary in Tollmann 1977, p. 153-155; Suess considered the Semmering rocks 'Lepontine' i.e. Pennine. They are now considered Lower Austroalpine) and concludes that the entire crystalline mass of the Eastern Alps, plus the Northern Calcareous Alps are swimming on a foreign substratum as immense nappes. He then points out that the crystalline frame of the Tauern Fenster carries its own Paleozoic and 
Mesozoic cover, which, surprisingly, does not correspond to that of the Northern Calcareous Alps and to its basement! The implied architecture is that three nappe systems lie on top of each other in the Eastern Alps and the whole overlies everything one sees in Switzerland. This is a prelude to Tollmann (1963)! This tri-nappe hypothesis is now generally accepted for the nappes to the east of the Tauern Fenster, but not for the nappes to its west.

The gneissic-granitic massifs known from within the Tauern window have taken part in the Alpine deformation and therefore they belong to the Alpine basement. The implied shortening is enormous. In eastern Switzerland and western Vorarlberg Suess gave a minimum value to the shortening: 120 $\mathrm{km}$.

In the entire chapter there is no mention of the fact that much of what he wrote in terms of the tectonic interpretations was anathema to most of the geologists of his own country who considered the entire structure autochthonous and rejected Termier's interpretation of the Tauern as a tectonic window. It took half a century, almost the entire duration of the Dark Intermezzo, for the general acceptance of the complete allochthoneity of the Austroalpine units as Suess described it in 1909.

The fifteenth chapter is a logical continuation of the previous two and deals with the eastern and the western continuations of the Alps and is entitled 'The posthumous Altaids'. First Suess gives one of the very few definitions in the entire Antlitz by defining what he means by 'posthumous Altaids':

"After the end of the construction of the eastern [this should be western. Suess' hand must have slipped here: Sollas did not catch it, but it is corrected in the French translation by the meticulous de Margerie. The Spanish edition surprisingly reproduces the incorrect 'eastern Altaids'] Altaids they were chopped up into horsts and later mountain ranges arose in the depressions between the horsts. It is these which we designate posthumous Altaids." (Suess 1909a, p. 219; 1909b, p. 194).

But he hastens to add that there are posthumous Altaid folds in the Paris-London Basin and in Portugal, but he will not deal with them.

Suess first summarizes the results of the two previous chapters under the subtitle 'The Alps'. He begins with what he calls the 'East Alpine Nappe'. It is divided into two: a southern half consisting of crystalline rocks and some Paleozoic and Mesozoic rocks covering it. In the north, by contrast there is a huge Mesozoic section resting on a much thinner Paleozoic section in the south that dips under it. The Mesozoic section is divided into numerous nappes during two phases of deformation: a pre-Cenomanian and another later. In the north, the Calcareous Alps rest on the flysch that dips beneath them. They float on a younger substratum that dips south under the entire Alpine edifice.

Under the East Alpine Nappe are the Lepontine nappes. They comprise everything between the overlying East Alpine Nappes and the underlying Helvetic Nappes. In Switzerland, these nappes occur as large outliers and as immense recumbent folds; in Austria, by contrast, they only show up in tectonic windows opened into the body of the east Alpine edifice. Suess did not know that the Rhenodanubian Flysch is in fact Penninic; he classified it as Helvetic. The Helvetic realm has a stratigraphy similar to the foreland and contains the external massifs that are just parts of the foreland overwhelmed by the nappes.

When Suess looks at the Alps as a whole he notes that the sedimentary series Silurian-Devonian-Lower Carboniferous is seen only at the back of the East Alpine edifice. Neither in the Lepontine, nor in the Helvetic Nappes is anything similar seen. He also notes that most nappes in the Helvetic and the Lepontine groups have formed from recumbent folds, whereas this is not the case for the East Alpine Nappes.

After having summarized the Alps, he turns to their northern and eastern continuation in the Carpathians; he reminds his readers that he had already dealt with this subject in the first volume, pages 246 (where he showed how the Bohemian Massif disappears beneath the northern Carpathians) and 285 (where he discussed the trend-lines of the Alpine System). Here he summarizes the progress of research and praises the meticulous work of the older generations. That work, he maintains, made it possible for Lugeon in 1903 to recognize that the north-dipping Subtatric elements had not come from the north, but, by contrast, far from the south by going over the units of the High Tatra. Suess follows Lugeon (1903) and Uhlig (1907a) in correlating the Subtatric nappe with the East Alpine nappe edifice and the High Tatra with the Lepontine units of the Tauern Window. It is clear that Suess' purpose here was to lend his support to the nappe interpretation of the Carpathian structure.

He ends the discussion of the northern and eastern continuation of the Alps by reminding his readers that the Carpathian shortening becomes ever younger as one follows the chain along its trend. The window of Paring and the torsion that leads to the Balkan chains are the last bits of the Alpides terminating eastward in free ends.

Having dealt with the northern and eastern continuation of the Alps, Suess turns to their southern and western prolongations. He follows the Apennines as a continuation of the Southern Alps southwards, describes the Triassic of Lagonegro, but in Toscana, Calabria and Sicily, another element joins the structure. In the north the Catena Metallifera, in Calabria the metamorphic massif plus its granite bodies and in Sicily the Peloritani Mountains Suess compares with the Mouthoumet north of the Pyrenees, although he underlines that they are not a foreland. They have taken part in the Apennine deformation.

When he crosses over to Africa and follows what he called the Mediterranean Atlas, he finds that here the structure of the Apennine is repeated. Three zones are distinguished: a northern 'volcanic' zone of islands (but in the west they also occur on the mainland: Suess mentions the Tifaraouine volcano, now known to be of Miocene age (see recent dissertation by Benali, undated), a middle zone of gneiss and schist and finally a broad southern zone of folds of sedimentary layers reaching into the Sahara. Suess follows these zones all the way to Gibraltar and then into the Betic Cordillera and finally into the Balearic Islands. In the Balearic Islands, he notes that Ibiza, Formentera, Majorca and Cabrera belong to the continuation of the Betics. On Minorca, however, there are Eifelian fossils, possibly also plant fossils belonging to the Culm. Suess notes that nothing like this had yet been reported from the young mountain ranges surrounding the western Mediterranean. In 
these chains he also notes that terrestrial Permian and German-type Triassic delimit the western Mediterranean in the north, west and south in the form of an easterly-opening letter C. Only when one goes in the direction of the centre of this $C$ is pelagic Triassic encountered (by that Suess actually means what we today call Alpine- or Mediterranean-type Triassic). He mentions that some would like to consider the socalled Saharan Atlas a part of the Atlas chains along the Mediterranean. He cannot agree with this: the Saharan Atlas resembles a structure more like the U.S. Rockies.

Up to this point, Suess has demonstrated that the entire Western Mediterranean (he did not mention the Valencia Trough though) is an area of young subsidence, just like the Tyrrhenian Sea. Here, too, mountain chains were built verging away from the area of subsidence and volcanoes characterized their internal parts.

In the northern margin of the western Mediterranean, in Provence, the situation is somewhat different. There are Cainozoic folds and thrusts with northern vergence. They go from the foot of the Mercantour-Argentera Massif all the way to the Montagne Noir and Mouthoumet. In the Montagne Noir Suess mentions, on the basis mainly of the publications by Pierre Joseph Jules Bergeron (1853-1919) north-vergent nappes of Paleozoic age. Thus the Montagne Noir is considered a part of the European Altaids. That the Montagne Noir is a part of the 'Hercynian' edifice is generally admitted (but see Şengör 2013), but now the vergence of the nappes south of it has been shown to be to the south and not to the north as Jules Bergeron had assumed (see arguments for both sides in Gèze et al. 1952).

The Provençal folds continue westward and are deflected by the Mouthoumet Massif, but Mouthoumet itself has taken part in the Cainozoic deformations. Through Mouthoumet, the Provençal chains join the Pyrenees.

Suess found a weird mountain range in the Pyrenees. He noted that they are two-sided with north-vergent nappes in the north, and south-vergent nappes in the south, although the north-vergent nappes are much better developed and it is they that continue westward all the way to Oviedo. The second peculiarity was the fact that their 'Altaid' core was the least high of all the Hercynian chains in Europe. Suess asked himself the question whether the Pyrenees were more a part of the Karpinsky Lines that entered Europe from Asia. When I studied the Pyrenees I was stunned by Suess' incredible insight concerning these mountains. The Montagne Noir, the Mouthoumet and the Pyrenees are indeed all products of major right-lateral strike-slip faults that both generated and eventually destroyed pull-apart basins giving birth to these mountain ranges today (see Şengör 2013). In Suess' world there were no major strike-slip faults with offsets of hundreds, if not thousands of kilometres. Yet he intuited that the Paleozoic Pyrenees were not as 'orogenic' as the rest of the Hercynian chains and somehow related to linear elements much more so than the rest of the Hercynian mountains in Europe. Suess ends by discussing the greenstone units, i.e. the ophites of the Pyrenees. He reminds his readers that Gustav Steinmann associated them with deep-sea deposits (see also Steinmann, 1927). Suess generally agrees with that and adds that they almost exclusively characterize the ocean bottoms, but, he says, here in the Pyrenees, in the Betics and in North Africa they are associated with sediments that were not deposited in deep basins. We now know that these exceptions represent subcontinental mantle rocks not ocean bottoms, or, as Suess expressed it, abyssal rock types. He gives the nickel occurrences in them as further evidence of their nevertheless deep origin.

In chapter sixteen, we are taken abruptly to the polar regions. Suess here begins with Ellesmere Island and northern Greenland, with the United States Mountains in northern Ellesmere Island. A south-vergent Paleozoic mountain range is here detected and it is also seen in northern Greenland. Its extent is little-known (for the present knowledge of this mountain system that covers the whole of northern Greenland and much of the Ellesmere Island, called Ellesmerian or Franklinian, see Higgins et al. 2000). Then Suess proceeds to describe what we today call the North American craton, which he had earlier called Laurentia. Here his terminology becomes inconsistent: he had earlier said that both the Appalachians and the Rocky Mountains are free ends of the Altaids, but developed in backfolding. The stable mass against which they were 'backfolded' must thus be the hinterland or backland according to his terminology and he had corroborated this by calling the Pacific Ocean foreland to all the chains surrounding it. Yet, here, he calls Laurentia foreland. He will similarly inconsistently call the Brazilian mass a foreland in the twenty-second and the twenty-sixth chapters. His inconsistency is particularly striking in the explanation of his world map at the end of volume III/2 where in two paragraphs he wrote the following:

"The Rocky Mountains — which in their northern part are folded towards the east, are then stowed against the Colorado Plateau and break up into coulisses - must be regarded as a free branch of the Asiatic System, which, relative to Asia, like the Romanzov Range, is backfolded.

.... ... western Altaids. These mountains advance south of the Horst of Azov, to Europe, from the middle and south of this continent, and reach the Atlantic coast, where they are very broad, between the southwest of Ireland and the Wady Draa. In this case, as in the Burman arc, the outer range exceeds all the others in length and then terminates in a free end. It dips beneath the sea in the ria coasts of Ireland and Brittany, reappears in the rias coasts of Newfoundland, forms the Appalachians, and reaches with its outermost spurs, on the other side of the Mississippi, even the outer border of the western Cordillera. In this way all the southern part of Laurentia is surrounded, as a foreland, by the outrunners of the Asiatic System." (Suess 1909a, p. 784, 1924, p. vi-vii; emphases are mine).

The two terms I emphasized in the above quotation are in flat contradiction with one another.

The same contradiction is implied in the following, taken from Suess' farewell lecture on $13^{\text {th }}$ July 1901 in the University of Vienna:

"Thus on both sides is North America encircled by concavestriking chains of folds. It is as if the folds extended away from Asia and towards Laurentia. This entire grand phenomenon may be illustrated by a comparison. By the eruption of Krakatoa the oceans were moved; long waves proceeded from the place of eruption, traveled around the entire earth, and met themselves on the other side of the sphere. But this 
is merely a comparison, not an explanation." (Suess 1902, p. 6; in the English version: Suess 1904c, p. 272; I only added the 'but' to the last sentence.).

In this quotation the forefolding/backfolding distinction seems to have been neglected. In any case, I cannot account for the presence of this terminological contradiction. Perhaps the oft-recurring phrase 'with respect to Asia' is a clue. But, in v. I and II the Pacific Ocean is repeatedly and consistently presented as a foreland. How then the Brazilian Mass can also become a foreland in v. III/2 is inexplicable. Perhaps Suess' concession that both the North and the South American cordilleras showed a two-sided structure, as well as the Caledonides in v. III/2, may have made him consider mountains with two forelands. Perhaps deep inside, he was unhappy with the backfolding interpretation for the Appalachians and the Rockies; but we can never know whether any of these possibilities were in fact the case. However we look at it though, the contradiction stands and any reader must be aware of it.

He describes the sedimentary cover of Laurentia. It begins with the Cambrian and encompasses much of the Paleozoic. Marine Mesozoic is generally absent. The Cainozoic is generally terrestrial or limnic.

Greenland, although an independent horst, was a part of Laurentia. Suess is aware of the basalt along the eastern shore south of Scoresby Sound, but not of the Greenland Caledonides. This is strange, because Alfred Gabriel Nathorst (1850-1921) had already reported Silurian rocks, folded and somewhat metamorphosed before the deposition of the Devonian, from the Narhvalsund side of Ella Island (Nathorst 1901, figure on p. 293). Suess cites Nathorst, mentions the fault he depicted, but not the folding. Perhaps he was unsatisfied with the suggested dating (Nathorst's figure in fact does not constrain the time of folding as he believed it did).

The Barents shelf contains the islands of Spitsbergen, $\mathrm{K}$. Karl, Franz-Josef's Land, Hope and Bear Island. With the exception of pre-Devonian rocks it has the structure of a table-land. Numerous steep faults cut it up. They strike mostly north-south. The islands of Jan Mayen, Faroe, the Hebrides and Iceland are volcanic characterized by a basaltic armour (Suess calls it Panzer) of Cainozoic age with an estimated thickness of some $3 \mathrm{~km}$ (We should note that only the inner Hebrides are volcanic, and even these only in part; Suess was aware of this through the publications by Sir Archibald Geikie \{1835-1924\}: see Suess 1901, p. 484; 1908, p. 396-397). Suess points out that such immense basaltic outpourings happened near the pole since the late Carboniferous, beginning with the Siberian traps and then the Jurassic basalts of Franz-Josef's Land and finally the great Cainozoic eruptions of Greenland, Iceland and the northern Atlantic islands of Jan Mayen, Faroe and the Inner Hebrides. Suess also mentions a dyke swarm cutting obliquely across the British Isles from the southeast to the northwest. Their ages are 'Tertiary', just like the great ring complexes of Scotland (we now know that they are in fact Paleocene to early Eocene in age: see Mussett et al. 1988). Suess emphasizes the association of the immense volcanism with the normal faulting. Along these normal faults the entire northern Atlantic had subsided. Despite this, he says, all these movements cannot be really regarded as stemming from deepseated tectonic dislocations. Everything takes place within the basaltic armour. Iceland is declared to be a Panzerhorst. This statement has some importance for a statement he will make in the next chapter concerning the origin of the great East African rift valleys.

Chapter seventeen is entitled 'African Fractures. Cape Mountains' and takes us again to a distant part of the globe, yet the subject is not entirely unconnected with the previous chapter.

I mentioned earlier in this paper that during the years 1887 1888 Count Sámuel Teleki de Szék (1845-1916) undertook an expedition to the northern part of the Great Rift Valley in Africa, in what is today northern Kenya and took with him the ship of line Lieutenant Ludwig von Höhnel to undertake scientific observations and measurements. Although the Great Rift Valley had been known as a topographic feature, its geology was not understood. It was the expedition of Count Teleki that enabled Suess to interpret correctly the tectonic nature of the depression. Admiral von Höhnel (1857-1942) wrote in his memoirs, how enthusiastically Suess greeted their observations and that it was he who suggested that the results be considered geologically and the specimens brought back be studied by his colleagues:

"A friendly relationship developed with time between me and Professor Suess out of initially only business-like connections. Upon his urging, the geographical, petrographical and the geological results of the expedition were worked up in detail for the Memoirs of the Imperial Academy of Sciences, on which he based his famous graben theory that was new for Africa and since then found general acceptance." (von Höhnel 1926, p. 78).

Von Höhnel published alone many of his observations and measurements (1888, 1889, 1890a, b, c, 1891, 1892), but it was the great Academy Memoir (von Höhnel et al. 1891) that drew the attention of the international geological and geographical community as a great novelty. In it Suess' epoch-making paper on the East African rift valleys was published (Suess 1891). It was for the first time the entire structure was outlined and interpreted as resulting from stretching acting perpendicular to the strike of the faults. However, von Höhnel was being optimistic about the reception of Suess' ideas on East Africa: Suess' interpretation was not immediately accepted, not even by his own students. He had already used in 1883 (in the first part of the Antlitz, p. 166) the old miner's term 'Graben' to designate areas that subsided between two peripheral faults delimiting round regions of subsidence, one normal, the other thrust. In east Africa, he applied it to sunken areas between two normal faults and this usage was immediately taken up internationally.

In the early to mid-twentieth century two different trends of thinking on the genesis of rifts competed: for the East African rifts, one was initiated in 1907 by Uhlig (1907b) who thought he could see evidence that the rift margins in East Africa were actually thrust faults and therefore interpreted the whole rift as a compressional structure. Similar ideas had been voiced about the Upper Rhine Rift already in 1887 (published 1892a, b) by Achilles Andreae (1859-1905), who had been followed in 1903 by Wilhelm Salomon [-Calvi] (1868-1941; Salomon 1903). Uhlig, however, gave up his idea in 1909, in favour of Suess' original interpretation.

Suess reiterated what he wrote in 1891 in chapter seventeen. He repeated that the bounding faults of the rifts con- 
verged downwards and said that the fracturing probably proceeded from the surface downwards. He said all this was because of stretching resulting from contraction (Suess 1909a, p. 316, 1909b, p. 281). It was this statement, left unexplained, that caused much confusion and bewilderment later. Although Suess had given sufficient hints: he said that the normal faults on both sides of a graben converged downwards and that rifting began at the surface and propagated downwards. The geological community had to wait until 1973 to find out how, with these specifications alone, rifting could be accomplished (Turcotte 1973; Oxburgh and Turcotte 1973; Turcotte and Oxburgh 1973; Solomon 1987; the German astronomer Jakob Karl Ernst Halm \{1866-1944\} had pointed out how it could be done earlier in 1935, but in a presidential address to the Astronomical Society of South Africa which was universally ignored by geologists). Figure 21 illustrates what I believe to be Suess' implied mechanism. It is here clear that in this mechanism the normal faults can only penetrate a limited amount into a shell the thickness of which can be calculated from the separation of the normal faults at the surface. Here it becomes clear why Suess emphasized in the North Atlantic that the normal faults there penetrated only an armour of limited thickness. The main problem with Suess' mechanism (and all subsequent employments of it by Halm, Lord Oxburgh, Turcotte and Salomon) is that the plates cannot store elastic stresses long enough to give rise to significant brittle deformation (see Burke and Dewey 1974 and Dickman and Williams 1981)

Suess next describes the northeast-trending volcanic line of Cameroon that begins in the southwest with the islands of São Tomé, Fernando Po and Príncipe. He points out that some include also St. Helena in this line of volcanoes. He says this is a similar structure to that of the East African Rift valleys with the exception that here a continuous rift valley was not created although there is much normal faulting. He follows the reports concerning the area of normal faulting almost as far as Lake Chad, but says extension that far into the continent is as yet uncertain. Modern research agrees with Suess so far as both the East African rifts and the Cameroon line are products of similar phenomena, but, unlike Suess, has shown that in both places uplift preceded both volcanism and rifting (for a modern interpretation of the Cameroon line, see Burke 2001).

Suess then discusses the plan of the normal faults in Africa. He counts the Cameroon Line, the north-south striking faults in Ahoggar, then the Great Rift Valley all the way into the Red Sea and the Dead Sea, finally ending with the Hatay Rift in Turkey. He interprets the Dead Sea Fault also as extensional. In all these regions, new normal faults are noted to follow the old lines of strike in the basement. Suess compares the normal faults and volcanic rocks surrounding the Atlantic and the western and northern parts of the Indian Ocean with those of the East African rifts. He says where these normal faults accompany the coast one sees no rifts and also in places no volcanic rocks. Where rifts occur, their width is surprisingly uniform: it varies between 30 and $50 \mathrm{~km}$. Only the Red Sea is an exception with a width that varies around 334 $\mathrm{km}$. The volcanic rocks associated with rifts are rich in alkalis but not in calcium and magnesium.

The last part of this chapter deals with the Cape Fold-belt. Suess has been in correspondence with a late Mr. Schenk and with the Survey geologist Arthur William Rogers (1872-1946).

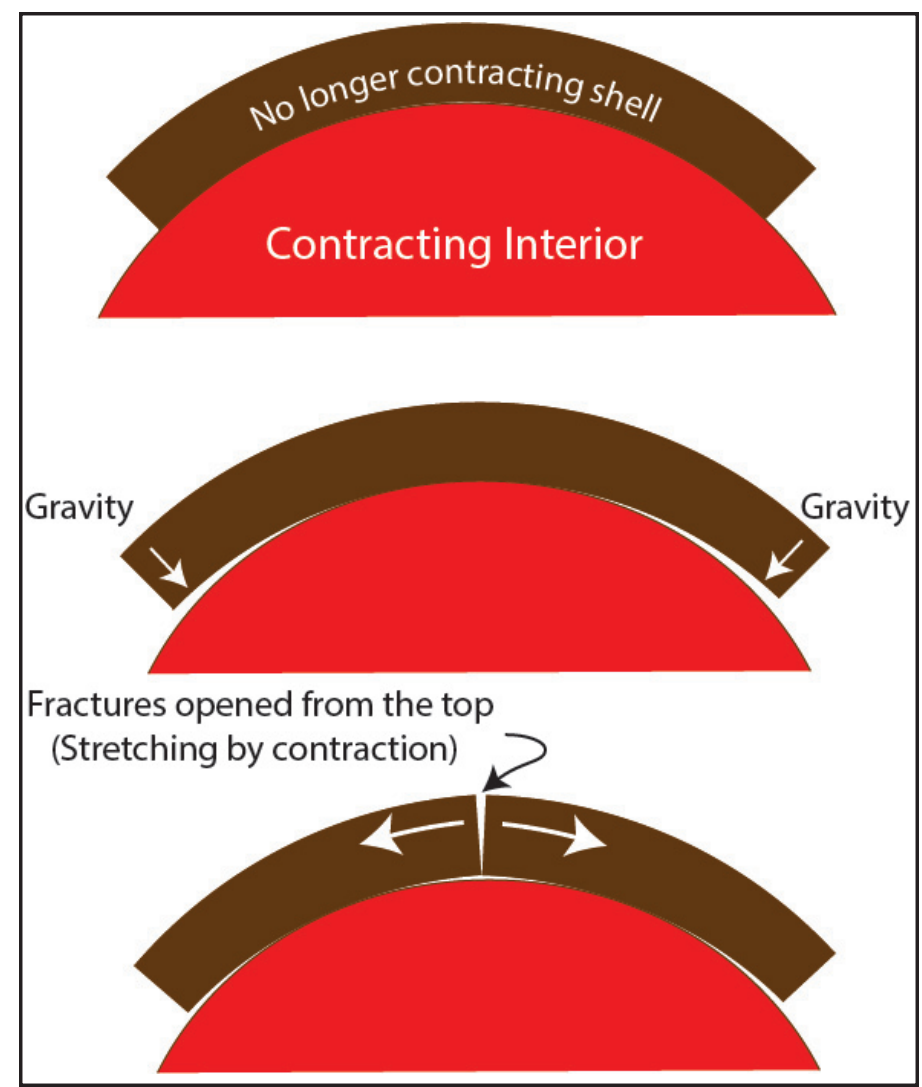

Figure 21. Extension caused by planetary contraction (Zerrung durch Contraction). In the uppermost figure, no contraction has yet occurred. In the middle figure, the hot interior contracted, but not the overyling already cooled plate. In the bottom figure, the ends of the non-contracting plate fall towards the interior because of gravity and shorten peripherally while leading to extension in the middle (see Solomon1987).

Mr. Schenk had informed him that the Cape folds are more extensive than formerly believed. Rogers wrote that the northsouth trending Cedar Mountains (Cederberg; in Afrikaans Sederberg) and the east-west trending Zwarte Mountains meet at a syntaxis in the southwest corner of South Africa. Suess compares this with the Himalaya and says that the Karroo is a foreland. Therefore, Africa is separated from any other southern continent by a foldbelt. This will be one reason why he will later separate Antarctica and Australia from Gondwana-Land, although he does not yet say it. He underlines that Africa thus has a fold-belt in the south that is north-vergent. He sees a sort of symmetry to the Asian structure in the north, which is south-vergent, but the southern mountain building seems to have come to an end much earlier, shortly after the Permian. Chapters eighteen to twenty-two inclusive are devoted to the Pacific Ocean and its frame. Suess begins in the southwest Pacific, with what he calls the Oceanides (chapter eighteen), skips the western Pacific island arc systems that he had already talked about and jumps to northern Asia and Alaska. He had left these aside while describing Asia, because of the close association of the northernmost Asian arcs with those in Alas$\mathrm{ka}$. He now makes his promise of describing them good (chapter nineteen). Chapter twenty deals with the Cordillera of North America and here the concept of Zwischengebirge (translated as 'intermediate range' by Sollas: Suess 1909b, p. 380; = intermontane space or middle zone \{Longwell 1923, p. 234\}, betwixt mountains \{Collet 1935, p. 24 \}or median masses $\{$ de 


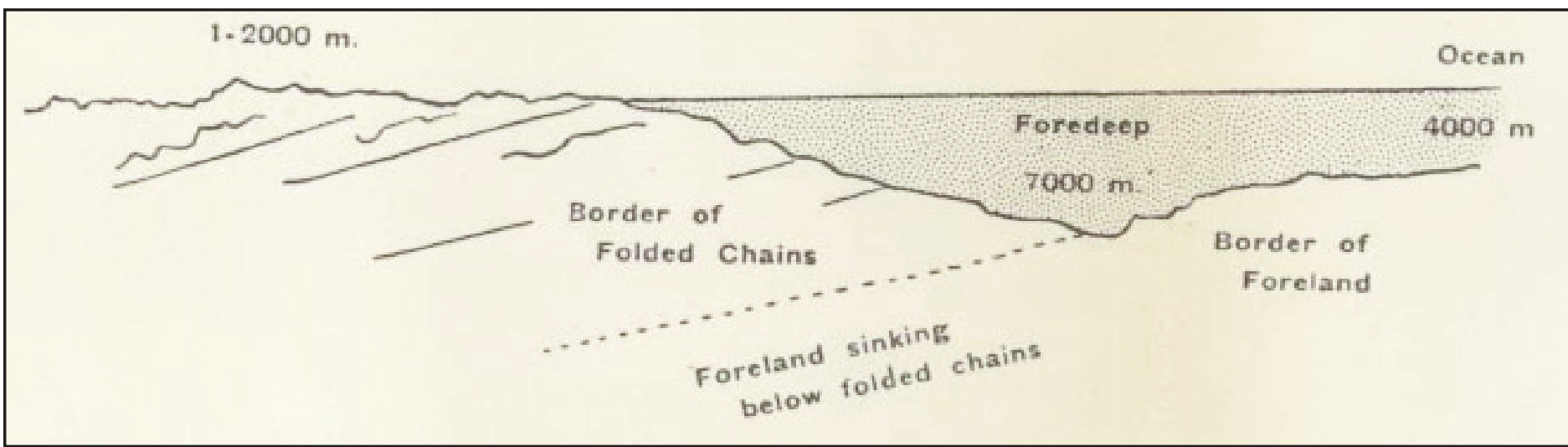

Figure 22. Suess' concept of the tectonics of the deep-sea trenches which he called 'foredeeps'. (Suess' own sketch in the unnumbered plate in Suess 1924).

Böckh et al. 1929, p. 60-61' $\}$ ) makes its first appearance (Suess 1909a, p. 435; 1909b, p. 380). Even the most reliable authorities today ascribe this term to Leopold Kober (e.g. Burchfiel 1987), although Kober himself (1883-1970; a doctoral student of Viktor Uhlig) says that he took it from Suess (Kober 1914, p. 254, footnote 1). Suess finally describes California and proceeds to the Andes in chapters twenty-one and twenty-two. Chapter twenty-two is the last of the regional chapters of the Antliti:

In chapter eighteen, Suess discusses first Australia and Antarctica. In Australia, the eastern mountain ranges were folded before at least a part of the Carboniferous. The Tasman Sea is a new subsidence. Westward, the Cretaceous transgression began with the Aptian. Farther west there are also Jurassic rocks. Suess says that these observations will be important for later comparisons. We will find out that it is mainly because of these two transgressions that he will separate Australia from Gondwana-Land, because for Suess a continent is almost synonymous with terra firma, i.e. land! Because this is not understood in our day, many geologists think -Land in GondwanaLand redundant. It is not, because it has nothing to do with forest, country, implied in the Sanskrit -wana! If -Land is removed from Gondwana-Land, we would not be able to understand Suess' meaning.

In Antarctica, he considers the entire east Antarctica plus the Victoria Land and the volcanoes of Erebus, Terror, Bird and Terra Nova to be parts of an Atlantic-type continental margin of a continent not dissimilar to Australia. Its geology is hardly known, so Suess lists all available observations: even a quartzite piece found in the stomach of a penguin! This part of the continent he calls Antarctis. Suess points out that the structure of the Cape Fold-belt requires both an easterly and a westerly prolongation, although so far there is no evidence to show that this is indeed the case. That he throws this sentence into the final paragraph of a discussion on Antarctica is interesting.

Suess then briefly lists the deep-sea trenches. He says that they had been called Rinnen (furrows, but Sollas translates Rinne as channel: Suess 1909 b, p. 294, which I think is inappropriate in Suess' context; de Margerie preferred sillon, i.e. furrow: Suess 1913a, p. 1012). Then the Austrian geographer Alexander Georg Supan (1847-1920) suggested in 1899 that they be called grabens, pointing out that this expression in this context applies only to the form (Graben = trench, moat, in German), not to the structure. He said they were intimately associated with folding. Suess agrees with this, but points out that it would be better to call them foredeeps. He follows the foredeeps from Japan, via the Izu-Bonin islands, the Marianas, the Yap (= Wa'ab) island to Halmahera. The foredeeps represent the oriental limit of Asia. Suess says with emphasis that the foreland sinks beneath them. He sketched what he meant upon the request of Professor Sollas and his sketch appeared in the maps and index volume of the English translation of the Antlitz (Suess 1924). I reproduce here in Figure 22 that amazing sketch which looks exactly like the one we draw across deep sea trenches today! Beyond the deep-sea trenches or the foredeeps in easternmost Asia lie Suess' Oceanides.

In the south, The Tonga-Kermadec-New Zealand line defines an island arc system, seen to have a west vergence in northern New Zealand and a foredeep which becomes deeper as one approaches Tonga. Suess says that the trench goes between Samoa and Tonga. He then reviews New Guinea and the islands between it and Fiji. He says that two arcs of volcanic islands seem to surround Australia and a third may be what we today call the Tasmanides themselves and in that case a vertex may be considered to lie within the Australian continent; but the way the eastern Australian ranges strike out northwards across the Torres Strait speaks against such an interpretation. Many connections are as yet unknown. Suess also notes the frequent occurrence of greenstone in the island arcs around Australia, but does not discuss them any further.

In the Oceanides there are lines of volcanoes that are also arranged in arcs. Suess asks whether the Paumotu Archipelago (the modern Tuamotu Islands) is yet another developing island arc system. He notes that Dana pointed out the migration of the volcanic activity in Hawaii and possibly also in the Samoan islands. Suess takes the Hawaii Islands as the northernmost of the Oceanides and interprets them all as evolving arc systems.

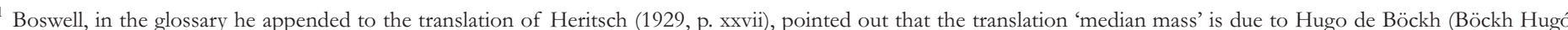

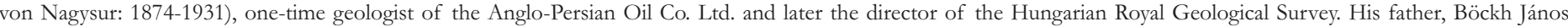
(1840-1909), was also a famous geologist and a student of Eduard Suess.
} 
Outside this zone there are individual islands in the Pacific Ocean such as Easter Island or the Galapagos Archipelago, but, Suess says, they resemble more the Atlantic islands than the islands of the Oceanides. He notes that in all of these islands basalt dominates, but other rocks such as gabbro and peridotite were also reported. All of the arc systems of the northern, western and the 'southern' Pacific are convex towards the ocean (the Hawaiian Archipelago being an exception) and it is clear that they are moving towards that part of the ocean, whose islands behave like Atlantic islands.

At the end of the chapter, Suess touches upon Darwin's theory of subsidence for the origin of atolls. He says that they are indeed built during positive phases of the motion of the strand as Darwin pointed out, but this is clearly interrupted by short negative movements. He observes that much of Oceania today shows the dominance of a negative phase in agreement with his conclusions in volume II. Suess' conclusion is corroborated by recent observations on Pacific islands (see, for example, the excellent synthesis by Dickinson 2001).

Chapter nineteen carries the title 'Entry of the Asiatic island festoons into America' and begins by describing three virgations: the Okhotskides, mountain ranges of Sakhalin, the Aldan Mountains along the shore and the Bureya. They converge towards the city of Jugjur. Another virgation has its apex almost at the Bering Strait at the town of Anadyr and assembles the magmatic arc system of the Kuril Islands plus Kamchatka and the Verkhoyansk arc, which Suess calls the Anadyrides. Finally a third virgation, called the Alaskides, takes up the entire Alaskan Peninsula plus the Aleutian arc. Suess expressly says later that all three belong to the Asiatic structure. Before proceeding to describe these, he takes a glance at the Taimyr Peninsula, but he cannot say much, because the observations are very inadequate. All he can point out is that the north of the Siberian mass is made up of gneiss showing up from under the Cambrian. He says they remind him of the Canadian Shield. On the Taimyr Peninsula the only strike measurement known to him was reported by Baron Nordenskiöld from south of the Chelyuskin Peninsula, the northernmost point of Eurasia: it is WNW-ESE.

He next describes the broad arc of the Verkhoyansk; although the geologist and physical geographer, Arctic explorer Baron Eduard von Toll (1858-1902) had thought the tectonic transport was toward the inner side of the arc, Suess had earlier expressed the view that it had to be the other way around. Both Arctic workers Benjamin Kendall Emerson (1843-1932) and Karl Ivanovich Bogdanovich (1864-1947) agree with him. Suess mentions this here, but says he will here follow von Toll, a martyr of science in these wild regions. From the way he presents the whole problem, it is, however, obvious that he had not changed his original idea, which, by the way, is the correct interpretation. He further mentions a northwest- to west-northwest-trending mountain range that runs into the Verkhoyansk. It is indeed what Sengör and Natal'in (1996) call the Alazeya-Oloy arc that literally rammed the Moma-Selenyakh arc, the internal part of the Verkhoyansk Mountains, during the late Jurassic.

Suess next describes the mountains along the northern shore of the Okhotsk Sea. He calls them the Kava Mountains. Although granite, syenite, basalt, diorite, andesite and rhyolite have been reported, Suess does not recognize a magmatic range here similar to the Andes. The material was too sparse. In Kamchatka, an old cordillera is recognized consisting of granite and porphyry carrying immense active volcanoes. The volcanoes are lined up along the eastern part of the peninsula, if the hot springs farther west are not considered as manifestations of active volcanism.

Finally Alaska is reached. Suess points out that the eastern end of the virgation previously mentioned also corresponds to a syntaxis: it reaches from the Chugatsk Bay (now Prince William Sound) all the way to the Arctic Ocean. Along it the northeast-striking Alaskides meet the northwest-striking Canadian Cordillera. Suess immediately reminds his readers that this place is a mirror image of the western Himalayan syntaxis. It is also similar to the Karroo Syntaxis. Then comes one of the very few places in the Antlitz where Suess explicitly states his methodology and aims in describing the structure and stratigraphy of mountain ranges. I quote him here in full because of the great importance of what he says. It was not understood (perhaps not even read) by most of his successors:

"When the syntaxis on the Jhelum was first described, distinguished Indian colleagues admitted the correctness of the facts, for the most part determined by themselves, but they refused to regard the bend in the strike as the principal boundary, in this case the boundary between the Himalaya and the Iranian arc. They pointed to the complete correspondence of the outer, Tertiary chains (I, pl IV; this is Suess' shorthand for Das Antlitz der Erde, v. I), and the resemblance between the structure of the chains of Hazara and Kabul and that of the chains situated to the east of Jhelum. This difference of opinion is fundamental. If we regard the stratified succession and nature of the rocks as determining the connection of mountain chains, then the second interpretation may often be maintained. But when it is a question of searching for the forces which have built up the mountains, then these characters take a second place, and the direction in which the tectonic forces have found expression will be decisive. Every syntaxis reveals a local opposition between two dynamical influences. It is for that reason that it forms a boundary. For that reason also no name given to a mountain should be carried on beyond a syntaxis." (Suess 1909a, p. 394; 1909b, p. 347).

This is what Hans Stille (1876-1966), one of the chief architects of the Dark Intermezzo, had to say about what Suess had done:

"... if Suess failed in his greatest synthesis, that of the Asiatic structure, ...this is because Suess saw too much the finished picture, and took into account its temporal evolution too little, ...” (Stille 1922, p. 4).

Here Stille makes a reference to Tietze (1917), which is possibly the worst guide to Suess' work, written as a complete misunderstanding of what Suess was saying by an incompetent geologist who felt a lifelong animosity against Suess fuelled simply by what seems to be jealousy (see Şengör 2014, p. 33). Had Stille read Suess carefully himself, very especially the paragraph cited above, instead of relying on Emil Tietze (18451931), he might have avoided the mistakes he made during his professional life. Unlike Suess', not much of Stille's theoretical picture today survives. Suess' Asiatic structure was a better description of the Asiatic structure than anything Stille later offered. 
Suess first depicts the tectonic subdivisions of Alaska presented by the great American geologist Alfred Hulse Brooks (1871-1924) in 1906 in his classical U.S. Geological Survey Professional Paper 45 entitled The Geography and Geology of Alaska, (Brooks 1906; Suess owned a personal copy of this book: see Anonymous 1914, p. 12) in which the subdivisions established in the Canadian Cordillera by George Mercer Dawson (18491901; he was Sir John William Dawson's eldest son and the President of the Royal Society of Canada for the 1893-1894 term) in 1879 are simply carried across the syntaxis, recognizing the 'Rocky Mountains' in the north (= Dawson's Rocky mountains; now the Brooks Range), the 'Central Plateau Region' in the middle (= Dawson's Interior Plateau) and the 'Pacific Mountains System' (= Dawson's Coast Ranges) in the south (for a visualisation of these subdivisions, see the coloured plate 20 in Brooks 1906, entitled 'Geologic sketch map of northwestern North America' facing p. 202). Suess has no quarrel with the way Brooks subdivided the tectonic units in Alaska, but thinks that the names should not have been carried over across the syntaxis. For him, Alaskides form one tectonic unit (Suess 1909a, p. 395; 1909b, p. 348). His divisions of the virgation are termed the Romanzof Mountains (north-vergent), the Alaska Mountains and the Kenai Mountains (both south-vergent). Their structure appears to Suess to be wholly Asiatic and a continuation of the Asiatic structure into America. Just as in Asia, active volcanoes are almost wholly confined to the southernmost, i.e. to the outermost branch of the virgation.

The twentieth chapter is called 'The End of the Island Festoons' and is really a description of much of the North American Cordillera minus California. Suess begins by reminding his readers the tri-partite division of Dawson. He says he will call Dawson's interior plateau temporarily Zwischengebirge, although he says that Dawson dropped his 'interior plateau' subdivision in 1897 (Suess 1909a, p. 435; 1909b, p. 380); Suess here specifically refers to p. 38 in Dawson 1897, where it is stated Disregarding however, all minor irregularities, two dominant mountain systems are discovered - the Rocky Mountains proper, on the east, and the Coast range of British Columbia, on the west.' But this is not all: on p. 39 Dawson continues, stating that between the Rocky Mountains and the Coast Range there are numerous less important mountain ranges, which are, although more or less parallel with one another, exhibit much less continuity than the two major bordering mountain systems. This is Dawson's Gold Range. To its west is the Interior Plateau, which Dawson retains as an important element in the structure of the Canadian Cordillera (on his p. 40) contrary to what Suess says. It comprises the area of a Tertiary plain of denudation with Miocene volcanics spread above it. From Dawson's description on his p. 40 and 41, it seems clear to me that he never gave up his Interior Plateau; it must be admitted however, that his presentation is unclear, because of his new insertion of the Gold Range into his scheme. Suess may have thought that Dawson simply lumped the Gold Range and the Interior Plateau into the Rocky Mountains. This, however, is not the impression I obtained from Dawson's text. It may be that Suess had read it in a hurry, took notes and later did not have access to it to check Dawson's precise meaning; in any case his private library did not have a copy of Dawson 1897, at Suess' death: see Anonymous 1914; in no library in Vienna was Mag. Thomas Hofmann, the able head librarian of the Austrian Geological Survey, able to locate a copy after a diligent search made upon my request. Suess must have obtained the copy he examined by mail from some library outside Vienna, and most likely outside the Austro-Hungarian Empire, and then returned it. The Zwischengebirge owes its distinction to a Tertiary table-land under which the folded ranges on both its sides continue. For it I shall here adopt the Swiss geologist Léon-William Collet's (1880-1957) translation 'betwixt mountains' cited above. Suess proposes to begin with the Rocky Mountains in the south, where he thinks they end, and to proceed northward all the way to the syntaxis and then to return to the south by describing the western ranges.

According to Suess the Rocky Mountains begin in the south, east of the stiff mass of the Colorado Plateau. In the United States, their geology reminds him of the Alpine external massifs, especially Mont Blanc and Aar. But large faults cut the folds in acute angles, so one is left in doubt whether these were real horsts or just anticlines cut by thrusts as in the Alps. In some places, such as along the outer edge of the 'Colorado Range', en échelon folds appear accompanying the uplifts. As far north as Yellowstone, the vergence of the U.S. Rockies is inconsistent. In Yellowstone, subsidence along normal faults predominates, some of which have throws of 1000 metres. With the Beartooth Mountains, the style changes completely and one enters the field of large overthrusts verging eastwards towards the prairie. This continues all the way to Alaska, near which even the Tertiary deposits are seen to have taken part in the folding. To the west of the sedimentary nappes (presentday 'Foreland Belt') is a belt of crystalline rocks (present-day 'Omineca Belt'): granite and gneissified granite. These are the main sources of the famous gold deposits here.

Suess notes the presence of an extraordinarily straight furrow just west of the Rocky Mountains north of the Canadian frontier. The great Canadian geologist Reginald Aldworth Daly (1871-1957) called it the Rocky Mountain Trench in 1906 (p. 596; also see his map on p. 588). Suess says that its significance is not clear. The Rockies end along the valley of the Tanana River, where their structure continues into the Alaskides.

Instead of describing the western ranges as he had earlier announced, Suess next describes the betwixt mountains ( $Z$ wischengebirge). In Canada, the depression containing the Wrangell group of volcanoes and the great Coastal batholith (which Suess calls the Columbian Granodiorite) are included in the betwixt mountains (Suess' betwixt mountains in Canada include the present-day Intermontane Belt and the Coast Belt). The graben containing the Wrangell volcanoes actually begins in Alaska and continues across the syntaxis to the southwest: between the Alaska and the Nutzotin Mountains in the north and northwest and the Kenai (=flat area, meadow, low ridge in local Athabaskan Dena'ina $\{=$ Tanana $\}$ language) and the Saint Elias Mountains (named after Mount Saint Elias, 5,489 m, so called by the Danish-Russian explorer Vitus Jonassen Bering \{Ivan Ivanovich Bering in Russian: 1681-1741\} in 1741 shortly before he died of illness on the Bering Island), in the south. From the Kenai Mountains southeastward Suess sees a series of Mesozoic-Cainozoic sedimentary rocks, in places containing blocks of limestone, folded and thrust towards the ocean. In the Saint Elias Range the highest peak consists of diorite and seems to be thrust on flysch-like sediments of the Yakutat Bay area. The sediments involved are young, reaching into 
the Tertiary. Suess points out that these mountains are still being built as shown by the 1899 earthquake which resulted in coastal uplift of various amounts around the Yakutat Bay (this earthquake began with a major foreshock on 10th September 1899, 17:04 UTC, estimated to have had a magnitude 7.4, which was followed by the main shock on the same day at 21:41 UTC with an estimated magnitude of 8.0. A maximum uplift of 14.5 metres was observed on the west coast of the Disenchantment Bay. Changes of 5 metres or more affected a large area and in a few areas subsidence of some 2 metres was noticed: Stover and Coffman 1993, p. 49-50 and fig. 8).

The Saint Elias mountains-type structure is lost in the Alexander Archipelago (named after Tsar Alexander II, 'The Liberator' $\{1818-1881\}$, who in the same year had sold Alaska to the United States out of fear that the British might occupy it) just north of where, in the Fairweather Range, the great granodiorite batholith comes to the shore along the Glacier Bay. Wherever the country rock is seen to its west it is, like the Saint Elias Mountains farther north, folded and thrust towards the ocean. In the south, from the Queen Charlotte Islands onwards, Suess sees a new element appearing which characterizes the western coast of the American continent. He will call it Andean Edifice (= Andiner Bau), but not yet in Canada.

Having described the Saint Elias Mountains he returns to the description of the betwixt mountains. All of the Alexander and the Queen Charlotte archipelagos Suess considers parts of the betwixt mountains. Beginning with the southern tongue of Graham Island he describes a Neocomian sequence (he calls it the Knoxville Stage) sitting on its basement across an unconformity. Southward, younger Cretaceous strata join the sequence thereby becoming more littoral and finally brackish. South of this are the Vancouver Island mountains, which are characterized by Triassic sedimentary rocks and mafic volcanic rocks (what is today called the 'Wrangellia Terrane': Jones et al. 1977). Suess concludes that the Vancouver Island mountains cannot be considered a continuation of the Alexander Archipelago, but a unit closer to the great batholith. It has only the Neocomian transgression in common with the Alexander Archipelago.

Eastward, the betwixt mountains are characterized by a plateau with volcanic table-lands. These overlie Miocene and Oligocene sedimentary rocks. From under these one sees Upper Carboniferous, Triassic and even Neocomian layers.
The Cascade Range of young and active volcanoes lies to the south and to its east is another so-called interior plateau. Suess says that Daly had pointed out that the region has no plateaux and therefore the name is inappropriate here. Following Daly's account, Suess counts as belonging to the betwixt mountains: Vancouver Island, Coast Range, Cascade Range, InteriorPlateau and a part of the (British) Columbia System. He considers as belonging to the Rocky Mountains: the remaining part of the (British) Columbia System, Selkirk, Coeur d'Alene (this famous mining district, the present resort town in Idaho, is near the junction of the southernmost Kootenay Arc and the Purcell Anticlinorium; for a recent description, see White 2000), Purcell Range and the Rocky Mountains (sensu stricto) ${ }^{2}$. The existence of young and active volcanoes sitting atop, or very near, the granite and granodiorite intrusions of up to Miocene or younger age suggests to Suess that the andesitic volcanoes and the great batholiths are the products of the same processes. He believes that the great batholith of British Columbia once must have carried similar volcanoes above it. Incredible as it may seem today, even this insight was lost during the Dark Intermezzo: Stille, for example, declared that 'synorogenic' plutons were genetically different from and older than the 'subsequent' felsic and intermediate volcanic rocks (Stille 1940a, especially p. 13-23, 1940b, 1950)! Bucher (1933, p. 268 and 289, footnote 48) did not even bother to discuss volcanism as related to orogenic events, because he considered them simply 'accidental.'

In the twenty-first chapter, called 'The Appearance of the Andes' Suess wraps up his discussion of the North American Cordillera. He first describes the Klamaths as a west-vergent chain characterized by at least five overthrusts carrying not only the clastic rocks, diabase and serpentinite, but also the radiolarite, one upon the other. As a whole they seem to dip beneath the Sierra Nevada batholith.

The Californian Coast Ranges also have a batholith, but this is supposedly much older than that of the Sierra Nevada. Suess thinks it may be Carboniferous or even older, because the Franciscan sedimentary rocks sit unconformably over it (we now know that this is wrong: the Coast Range granite plutons are Mesozoic and the contacts are all tectonic). The whole area and farther south and east is all chopped up by long, northwest-southeast striking faults. Suess follows them eastward and declares Death Valley a half graben and compares it

\footnotetext{
${ }^{2}$ For the readers who might wonder why the 'sensu stricto' here is needed, let me quote John Wesley Powell (1834-1902): 'That portion of the United States west of the one hundredth meridian lies at a great altitude above the sea. The exceptions to this, as immediately along the Pacific coast and the narrow valleys of some of the principal streams, are but trivial. The rivers descend so rapidly from the upper regions that few of them are of value as highways of commerce; the valleys proper are narrow; treeless plains, cold, arid table lands, and desolate mountains are the principal topographic features. The more conspicuous of these are the mountains; lone mountains, single ranges and great groups of ranges or systems of mountains prevail. Owing to great and widely spread aridity, the mountains are scantily clothed with vegetation, and the indurated lithologic formations are rarely masked with soils, and the rocks, as they are popularly called, are everywhere exposed; hence all these mountains are popularly known as the Rocky Mountains. But there is more than one system of mountains, and later writers wishing to be more definite speak of the Cascade Mountains, the Coast ranges, the Sierra Nevada, the Wasatch Mountains, \&c. But in an important sense the region is a unit; it is the generally elevated region of the United States; it is the principal region of the precious metals; it is the region without important navigable streams; it is the arid land of our country where irrigation is necessary to successful agriculture. But above all it is the rocky region; rocks are strewn along the valleys, over the plains and plateaus; the cañon walls are of naked rock; long escarpments of cliffs of rock stand athwart the country, and everywhre are mountains of rock. It is the Rocky Mountain region.' (Powell 1876, p. 4-5).

It is in that sense that most Europeans used to learn about the Rocky Mountains (e. g. Termier 1920, p. 10). That was how I learned it at school in İstanbul. Daly (1906, p. 589), coming from a Canadian perspective where the western mountains are extensively covered with forests, thought it wholly inappropriate contrary to Powell. Now, North American geologists use the designation made popular by Alexander von Humboldt (1769-1859), namely the 'Cordillera,' for what Powell referred to as the Rocky Mountain System. Gilman (1872, p. 117) noted that it was Josiah Dwight Whitney (1819-1896), who proposed the term 'Cordillera of the United States' 'for all that vast and intricate system of upheavals lying along the western portion of our territory.' and Suess' 'Rocky Mountains sensu stricto' refers to the US Rockies and the Canadian Rockies in the common terminology of our own day.
} 
with the Dead Sea rift. This region and farther east is the Basin and Range area and here Suess reports both Precambrian and thick Paleozoic sections beginning with the Lower Cambrian in the White Mountains (he cites Walcott 1895a). He mentions Walcott's other 1895 paper on the White Mountains also (Walcott 1895b) saying that Walcott proved westward thrusting here. Unless Suess himself interpreted Walcott's sections showing mostly westerly dips as indicating westerly transport, his statement is not true. Walcott himself made no pronouncement about the direction of tectonic transport, but his sections to me suggest eastward transport (see Walcott 1895b, figs. A, B, C, D, and E on p. 172). The most recent structural analysis of the area known to me clearly shows easterly tectonic transport (Stevens and Stone 2005). My suspicion is that we again have a slip of Suess' hand: writing westward when he meant to write eastward. This error even de Margerie did not catch and it appears uncorrected in all translations.

Regarding Baja California, Suess agrees with the most recent opinion then expressed that the peninsula is just a continuation of the Upper Californian Coast Ranges and that the Gulf corresponds to the longitudinal valley of Sacramento (what we now call the Great Valley).

In the next subsection, the new observations on the Colorado Plateau are reviewed with the aim of showing how the Appalachian/Ouachita folds in the east (in west Texas) approach the Cordilleran folds in the west. In front of the southwest edge of the plateau is a region about 110-200 km wide. Its western limit is defined by a line going through Fort Mohave, Phoenix and Tucson. This is normally considered a part of the Basin and Range, but Suess points out that the Cordilleran folding is not yet seen here. Beyond it, in the districts of Globe and Clifton-Morenci, the Cretaceous shows up above an unconformity. This unconformity had not been caused by previous folding, however, but by erosion. Here the thick Gila Conglomerate appears. It dips to the southwest and only beyond it can one be sure that one is in the Mesozoic series of the Cordillera.

The southeastern limit of the Plateau is different. The Rocky Mountains have already reached their end here. A number of sierras trending southeast appear between the Rio Pecos and Rio Grande. Here the Paleozoic sequences begin to get thicker 'as often happens when a folded region is approached' (Suess 1909a, p. 491; 1909b, p. 431).

In Mexico, the southeast-trending sierras continue and occupy a wide zone all the way to the western shore. Beyond it, Baja California, Islas Marias and the Sierra Madre do Sur define a gentle curve embracing all the sierras of the mainland. Suess says that until two decades earlier one distinguished a Sierra Madre Occidental, a Meseta Central and a Sierra Madre Oriental. But now modern research has shown that in Mexico there is really only one orogenic belt. Young volcanic rocks cover the 'Meseta central' and, in the east, the fold and thrust belt belonging to the single orogen is seen. A Sierra Madre Oriental does not exist as an independent tectonic unit (see especially, Suess 1909a, p. 498; 1909b, p. 438). Its easternmost folds reach the Gulf of Mexico, along the margin of which a marginal arc-shaped fault zone is not seen. A part of this area in Sonora, Puebla, Oaxaca and even in Honduras was land during the late Triassic, whose plant-bearing deposits sit, in places on possible Paleozoic and in others on Precambrian basement.
Towards the middle of the country, a marine Carnian fauna was discovered. This is followed by a fairly complete Mesozoic sequence with the exception of Middle Jurassic which has not yet been reported from anywhere else in the area. Eocene and Miocene do not penetrate far inland anywhere. Then follow the volcanic rocks. This volcanism is still active and created some of the grandest volcanoes on earth. Suess lists Orizaba, Popocatepetl, Iztacchiuatl, Nevado de Toluca, Colima and Jorullo.

Structurally, one sees a very considerable shortening of the Cretaceous limestone building recumbent, plunging nappes. The axes of these nappes dive and rise in a way that, had the recumbent structure not been seen around their ends, one would have thought the region a quaquaversally dipping dome! Volcanism and extensive normal faulting and subsidence follow this folding. In the so-called Sierra Madre Oriental, the folding has followed the Laramie Stage and ended before the Eocene. The coal-bearing beds strike into Mexico from their extensive areas in the United States. The volcanic rocks of the Sierra Madre Occidental bend into those of the young volcanic zone reaching the Atlantic shores. The east-west fissure presumed by Alexander von Humboldt to have localized these young volcanoes does not exist.

Finally in this chapter, Suess describes the stratigraphy of the betwixt mountains. The purpose of this detailed discussion is to discover the origin of the marine deposits in the southernmost United States starting with the Permian. But first, here is Suess' most detailed statement about the geographical extent of the betwixt mountains in the North American Cordillera that he placed at the beginning of his present description of their stratigraphy:

"The tectonic element, which we called the betwixt mountains, first makes its appearance on the borders of the Copper River Platean beneath the lavas of the south side of the Wrangell volcanoes and in the Scolai Range. In the Alexander Archipelago the characters of forelying Elias Range disappear and the betwixt mountains then include the Columbian Granodiorite and the Interior Plateau. It sinks to no inconsiderable extent beneath the lavas of Washington and Oregon, makes its appearance again, with the same characters, on the boundary of Oregon and Idaho, embraces in Nevada and Utah the whole of the desert region from the Sierra Nevada to the Wasatch; and in Arizona and southern California is hemmed in between the Colorado Platean and the Pacific coastal chain, possibly indeed interrupted by them. South of the Colorado Platean it again appears and is very broad, extending eastwards even as far as the Pecos. Its folded sierras are here sharply separated from the table-lands of Texas, although the Cretaceous limestone is the same in both. It then occupies the whole centre of Mexico up to the Sierra Madre del Sur, and, finally, after the strike has turned out of the south and south-southeast into the southeast, reaches the Atlantic coast between latitudes $19^{\circ}$ and $26^{\circ}$ N." (Suess 1909a, p. 502-503; 1909b, p. 442-443).

Suess shows that up into the Jurassic the marine waters in western Texas and farther to the west and northwest and their faunas came from the north, in some cases all the way from the Arctic. Some of these faunas show clear 'European' affinities, although a direct, easterly connection across the Atlantic did not exist. Some authors considered the faunas also 'Indian', 
but Suess says that they are simply Indo-European (what we would now, somewhat inappropriately, call 'Tethyan') as known from the Southern and Eastern Alps. From the existing reports, says Suess, one concludes that the thick Lower Paleozoic sequences of the east abruptly end in the middle of the Basin Ranges along the $117^{\circ}$ meridion (central Nevada). The Lower Paleozoic continues towards the Mohave Desert and Devonian was also cited from the Klamaths.

The twenty-second chapter is the last of the regional chapters of Das Antlitz, der Erde. In it Suess discusses the structure of the Andes including the Caribbean and the Southern Antilles. That is why the chapter is entitled 'The Andean Structure; its twofold advance'. This was also the subject of the last class-room lecture he gave in the university before his retirement (Suess 1902).

Suess begins his description in southernmost Mexico (Chiapas) and Guatemala. Old basement rocks consisting of gneiss, old schist, crystalline limestone, granite and porphyry cross the low Isthmus of Tehuantepec and continue into Guatemala. Rudist limestone accompanies the old rocks and to the north there is a weakly folded Tertiary section. Therefore, the Tehuantepec depression is only a morphological boundary, not a major tectonic one. Atop this basement in Chiapas are the volcanoes such as Zontehuiz.

From here south the mountain ranges open up into a virgation and turn southeastward along the Motagua River. Some strike into Cuba. The Bartlett Deep Suess thinks represents a foredeep to such mountain ranges as the Sierra del Mico and Sierra de Espirito Santo along the northern shore of Guatemala. Farther north, the Grand Cayman is part of another series of ridges for which the Yucatan Trough is the foredeep.

The Antilles trend from Cuba westwards and turn around and join the Andes in Venezuela. Suess says that the southern junction in Trinidad and Tobago had been disputed, but he points out that the strike in Trinidad turns to the northeast so as to complete the curve. In front of Barbados there is not much of a foredeep, simply because the fill of the deep-sea trench here was deformed and uplifted. Farther north there are foredeeps and Suess says they look just like the ones in Asia and Alaska. He considers the Antilles to have a Pacific-type structure.

In the south, the mainland and the islands to the north have metamorphic rocks and radiolarite. They are cut by long, east-west striking faults that join the Sierra de Perija and thus the northeast trending branches of the Andes.

Within the Andes themselves, Suess recognizes an eastern Cordillera that largely carries the basement and the stratigraphy of the Brazilian mass (which he again calls, inconsistently, foreland) a central area of Mesozoic sedimentary rocks and volcanoes and a western strip of older rocks. The central area greatly resembles the betwixt mountains of North America. As one comes into Argentina, the sedimentary folds and thrusts give way to longitudinal faults along which horst- and graben-like structures take up the shortening. Suess says he can only compare these with the structure of the U.S. Rockies. His interpretation and comparison remains valid to this day. Identical comparisons have been published in the last three decades of the twentieth century with no reference to Suess (e.g. Jordan and Allmendinger 1986).
Finally in the south, another virgation introduces the South Sandwich Islands, which Suess calls the Southern Antilles. They go around just like the northern Antilles and join the Graham Land in Antarctica, which is only a continuation of the Andes.

Thus ends the description of the face of the earth by Eduard Suess. The concluding chapters of the Antlity, from twenty-three to twenty seven, are devoted to the theoretical questions that occasioned the writing of this book and to those which arose while writing it, from the internal structure of the planet to life on its surface. It is in these chapters that such terms as listric faults, nife, sima, sial (as sal), refugia for life (Suess called them asylums), etc. are introduced and terms such as backfolding, syntaxis, linkage, virgation are discussed in terms of what they tell us about the movements that create mountain belts. Suess reiterates his analogy of nappes with glaciers and says that extra weight accumulating in mountains leads to their spreading both in forefolding and backfolding. It is disconcerting to realize how many of his concepts introduced in a book published in four international languages had to be reinvented later.

In chapter twenty-three, simply entitled 'Analyses', Suess begins with a discussion of the map view of the surface of the planet, literally with its Antlitr (= face, countenance). He first lists the first-order tectonic entities he had discovered and described. These are: 1) Laurentia: limited by the Rocky Mountains, the Appalachians, the United States Range (i.e. the Ellesmerian or Franklinian Orogen). It includes Greenland and possibly the entire North Atlantic fracture field including Jan Mayen and even the Outer Hebrides. In the south, Suess considers the Colorado Plateau and the Llano Uplift in Texas as belonging to it. 2) Caledonides: a south-southwest-striking preDevonian mountain chain. Its traces are possibly seen in Spitzbergen. It lies between the gneisses of the Hebrides in the west and those of the Baltic Shield in the east. In the east it is east-vergent; in the west, west-vergent. 3) The Asiatic (or Eurasiatic) Edifice (Sollas translates this as Asiatic (or Eurasiatic) System: Suess 1909b, p. 499): in North America, the United States Range, the Rocky Mountains, the Elias Mountains and the Alaskides; almost the whole of Asia with the eastern island arcs including the Bonin Islands, to the foredeeps of Palau and the Talau islands, the Burmese arc, and all the mountain ranges sharply delimited to the south from the mouth of the Ganges to the western end of the High Atlas are included. Entire Europe belongs here with the exception of the Caledonides and the possible Laurentian parts in the Hebrides. A long free branch crosses the Atlantic and forms the Appalachians. It dies out in Texas and Oklahoma. Entire northern and northeastern Asia belongs to this edifice. In northern China, Cambodia and Borneo there are unfolded regions within it. In Europe, it shows the peculiar history of having localized small basins out of which the posthumous Altaids, such as the Alps or the folds of the Paris-London Basin grew. The Caledonides have soldered the Asiatic Edifice to Laurentia. The continent Eria extended over this juncture. 4) Suess sees in the Bohemian Massif a small but ancient fragment encompassing Bohemia, Upper and Lower Austria, Moravia and Bavaria. 5) Gondwana-Land: South America from the Andes all the way to the eastern coast including the Falkland Islands, the whole of Africa from the southern limit of the High Atlas to the 
Cape Mountains, Syria, Arabia, Madagascar, India with Ceylon. I emphasize again here, that Suess excluded Australia from Gondwana-Land in this volume, because unlike the rest of the continent, Australia had pre-Cretaceous transgressions affecting it. The Saharides are not separated from Gondwana-Land. Moreover, in Africa mainly north-south fractures deformed Gondwana-Land later; also a northeast-southwest line along the Cameroon trend. 6) The Cape Mountains: Suess says we have no idea how they continue to the east and west, although he has no doubt that they must. He says they were like the Altaids, but became dead much earlier. 7) Australia and the Oceanides: Australia is a sort of vertex, like the Siberian nucleus and the arc systems of the Oceanides are for Suess the future Altaids. Modern research has very much followed him in this analogy as well (see for example, Sengör et al. 2014a). 8) The Andean Edifice: This begins in western California and reaches all the way to Graham Land, including both the Northern and the Southern Antilles. The easternmost Andes deformed what are clearly Gondwanian strata. Suess is puzzled as to why the Andes did not build arcs like those along the eastern margin of Asia. He wonders whether the Brazilian Mass hindered their formation. 9) Antarctis: South Victoria and Wilkes Land to the Gauss Mountain; on the other side Coats Land may be a continuation of South Victoria. The volcanoes there (Suess calls them the Terror series) are to be compared with the East African volcanoes.

This was the first tectonic classification of the Earth's surface based on geological data (as opposed to Élie de Beaumont's orographic classification) ever attempted and most of its elements are still with us. All subsequent classifications, without exception, have been based on Suess' work and its example.

He next deals with some the elements of the trend lines. He first treats linkage and syntaxis. In linkage it is important to know which arc is the dominant element. Suess gives the Carpathian/Variscan arc linkage, whereby the Carpathians overrode the Variscan arc for very considerable distances, as a first example. In this linkage the dominant arc is that of the Carpathians. In another kind of linkage, like that of the eastern Himalaya, the earlier-formed chain becomes the dominant arc: in that case the Burmese Arc (Fig. 23). He compares the arcs meeting at syntaxes and linkages with those forming in asphalt cover of the streets (Fig. 24). As the reader is about to think this comparison odd, because Suess has so far repeatedly emphasized that arcs are structures of immense thrusts, Suess reminds his readers that the volcanoes along mountain and island arcs are nucleated on extensional structures. That is why, he says, the volcanoes in island arcs do not sit on growing cordilleras but behind them, not infrequently in the sea! He finally says that although the resemblance of the asphalt cracks and the island and mountain arcs exhibit an uncanny resemblance, one should not go too far into thinking them cogenetic.

Next he deals with the foredeeps. It is clear that along them forelands underthrust mountain ranges for very considerable distances (hundreds of $\mathrm{km}$ ! see his sketch reproduced here as Fig. 22). The volcanoes accompanying island arcs or other mountain arcs are never seen in foredeeps.

Under the heading 'folding', Suess deals only with virgations and their two kinds: free and forced. Free virgations form

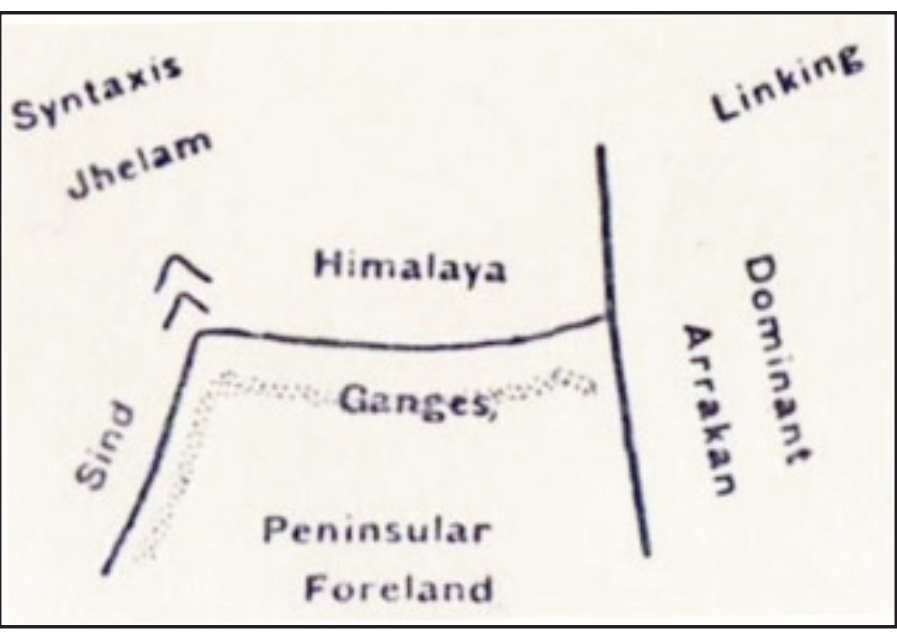

Figure 23. The syntaxis of the western Himalaya and the linkage of the eastern Himalaya. (Suess' own sketch in the unnumbered plate in Suess 1924).

when a number of free branches radiate from a common stem and die out along the strike. Such branches, called 'branchfolds' by Suess, may have grown in time along the strike (Suess calls this process Fortbau: growing away: 1909a, p. 583; 1909b, p. 507; Stille later used this concept without reference to Suess: Stille 1924, p. 273-275). Forced virgations occur secondarily when a number of such branches are forced to crowd together because of an inhibiting stiff mass in front of them.

Suess points out that backfolding (= Rückfaltung) occurs because the mountains getting higher need to spread themselves to get rid of the 'high extra mass'. The Altaid folds verging towards the Siberian nucleus are backfolds. So are the entire Variscan and Armorican Arcs, the Appalachians and the Rocky Mountains. They overthrust Laurentia in backfolds, yet Suess here again inexplicably calls Laurentia foreland of both the Appalachians and the Rockies.

He ends this chapter by discussing a number of classical profiles such as the Alps, the Belgian coal fields and the Scottish Highlands. It is during these discussions that he introduces the term listric fault to describe thrusts. To my knowledge, Suess nowhere used the adjective listric for normal faults. He finally returns to his favourite comparison between glaciers and rocks to explain the geometry (both in cross-section and map view), internal strains and the displacements of large nappes in mountain belts.

Chapter twenty-four is devoted to the depths of the planet, to batholiths and melting phenomena and finally to the greenstone. It is simply entitled 'The Depths'. Here Suess first presents a subdivision of the earth's interior on the basis of Gabriel Auguste Daubrée's (1814-1896) comparison of the range of compositions and densities of meteorites and possible layers of the interior of the earth and Emil Johann Wiechert's (1861-1928) geophysical, especially seismological, studies. Wiechert had concluded that the earth had a rock mantle of some $1400 \mathrm{~km}$ thickness with a density between 3.0 and 3.4 and an iron nucleus with a density of 7.8. Suess says that new observations make a 1500 km-thick mantle likelier. Richard Dixon Oldham (1858-1936), son of Suess' acquaintance Thomas Oldham, the first superintendent of the Geological Survey of India (1816-1878), estimated a discontinuity at $1594 \mathrm{~km}$ depth. Suess recognizes a Nife $(\mathrm{Ni}-\mathrm{Fe})$ or bary- 


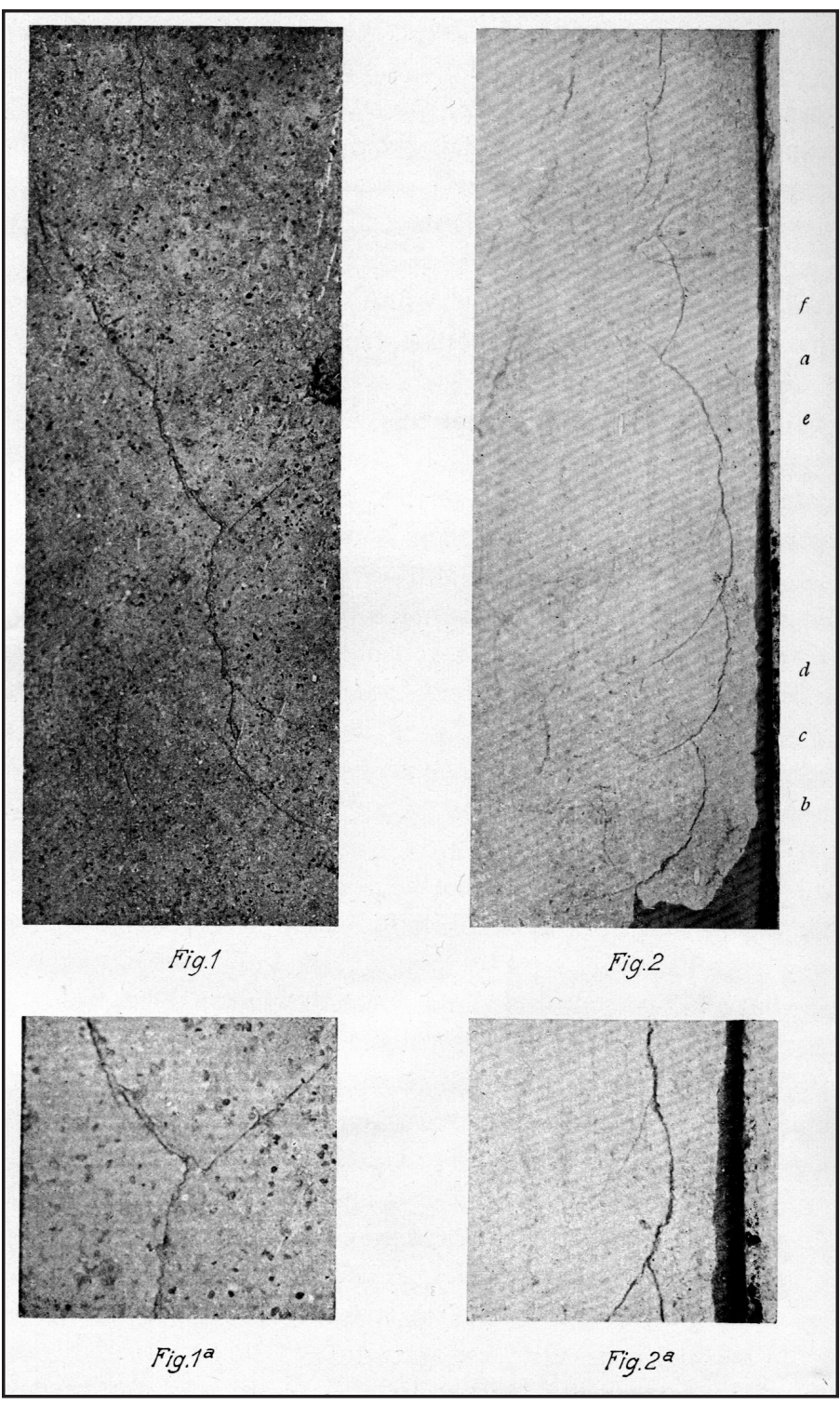

Figure 24. Extensional structures in asphalt (from Suess 1909a, plate 20; Sollas 1909, plate 4, translated this as 'cracks in asphalt', which is not exactly correct from the viewpoint of what Suess wanted to express here. One should bear in mind that Sprung in ordinary everyday German is indeed crack; but in the language of the miner, it is a normal fault. Suess here wished to emphasize the extensional character of the arcs and their linkages.).

sphere, a Sima (Si-Mg) and $\mathrm{Sal}(\mathrm{Si}-\mathrm{Al})$. Suess notes that in meteoritic iron some heavy metals are encountered, such as platinum, iridium, and gold. These, he says, are found on earth in rocks that indicate an origin in Sima, in association with $\mathrm{Ni}$, $\mathrm{Cr}$ and Fe. In the nickel ores of Sudbury, for example, platinum, occurring as sperrylite $\left(\mathrm{PtAs}_{2}\right)$, is obtained from nickel ore. From Scandinavian nickel ores gold and platinum had been described. The platinum bodies in Nijni Tagil, along the Urals north of Yekaterinburg, are found in limonite. The richest platinum find in North America, at the Similkameen River in Canada was made in a 'simatic' region. In addition, Suess mentions the awaruite (nickel and iron alloy) occurrence from the Klamaths and the South Island (Te Waipounamu) of New Zealand. Finally he lists the gold- and osmiridium-containing serpentinite from Oregon, California, northern Italy and finally from the moraines of the Aosta Valley in the Italian Alps.
After listing all these Suess says that the occurrence of simatic rocks at the earth's surface is not all that rare. This reflection brings him to the importance of the green rocks in tectonic studies. He says that the spectral studies show that the materials forming the sima are often seen in stellar compositions, but not so much sialic materials. He concludes that simatic materials must be much more abundant in the universe. But before discussing the green rocks in any detail, he has two other subjects to cover: the degassing of the planet and the batholiths.

Suess thinks the oceans are a product of the degassing of what he here names juvenile water as opposed to the Czech geologist František Pošepny's (1836-1895) vadose water. He says the juvenile hot springs bring to the surface unexpected elements. In addition to $\mathrm{H}$, volcanoes bring up $\mathrm{Cl}, \mathrm{F}, \mathrm{S}, \mathrm{As}, \mathrm{C}$ and a series of other materials.

Next Suess comes to the batholiths correcting an error he says he committed in the first volume when he wrote that batholiths fill in pre-existing empty cavities. He now thinks they rise by melting and assimilating their country rock. The connection with volcanism is more closely studied especially in the light of Joseph Barrell's (1869-1919) description of the mining district of Marysville in Montana. Before going into this Suess reminds his readers the great German petrographer Karl Heinrich (Harry) Ferdinand Rosenbuch's (1836-1914) division of igneous rocks into abyssal, dyke and effusive rocks (although Suess cites no reference here, he clearly had in mind Rosenbuch 1898, p. 33-364 or the second, 1901, edition). Injection dykes accompany the batholith in Marysville. These must have been of sudden origin, for otherwise the magma would have solidified before being able to form the long dykes. Barrell had said that these resemble products of volcanic phenomena. Suess says let us imagine that one of these dykes reaches the surface, forms a volcano, discharges the magma and juvenile material and thus arrests the rising of the batholith. Alternatively, Suess says, the roof of a batholith may founder, numerous fissures originate and volcanoes form. $\mathrm{He}$ adds that under eroded volcanoes one frequently encounters subvolcanic or batholithic rocks.

He then reminds his readers that in some places sandstonefilled neptunian dykes are seen that have been filled from below. Therefore, he says, in igneous phenomena we should perhaps not ignore the role of hydrostatic pressure. He reviews some of the horizontally intruded igneous material thereby mentioning the great American geologist Grove Karl Gilbert's (1843-1918) laccoliths. Suess says that these lateral injections show the behaviour of magma during mountainbuilding events.

Finally in this chapter Suess discusses the greenstones. He had already dealt with them in an earlier short paper (Suess 1904b) and emphasized the frequent occurrence together of diabase, gabbro and serpentinite, thus recognizing the igneous part of what later became known as Setinmann's trinity after his famous 1927 paper (the term was coined by Bailey and McCallien 1960, p. 366; they do not cite Suess). We learn that these rocks are peculiar to mountain belts and never occur in forelands. Suess also points out, following Steinmann, that they occur in association with deep-sea sedimentary rocks such as radiolarite, even if not invariably (he gives those in the Pyrenees as a counter-example). He thinks they are deep-seated rocks, originating in the upper mantle and brought to the sur- 


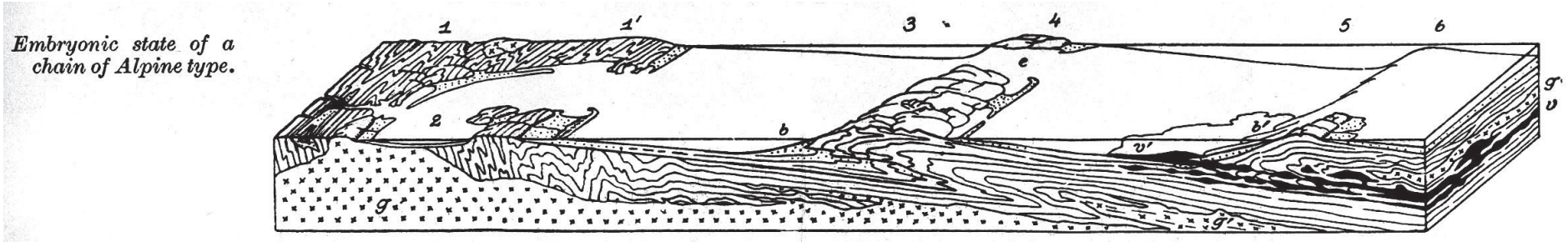

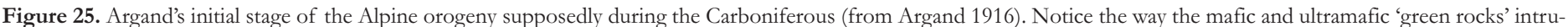
de and extrude along thrust planes. Argand owes this idea to Suess.

face by thrusts; some are sills injected along thrust planes. This last point found a beautiful and most influential illustration in Argand's famous figure in his classic Sur l'arc des Alpes Occidentales (Argand 1916; here Fig. 25). Suess also observes that almost all oceanic islands are basaltic and that it seems likely that ocean floors generally consist of heavier rocks.

Chapter twenty-five treats the volcanoes: their modes of eruption, connection with dykes, distribution and the division of lavas into Pacific and Atlantic types.

After discussing the dykes Suess intercalates a discussion on the South African kimberlite chimneys. He mentions that they occur in groups and some are in association with dykes. He does not wish to discuss in any detail their composition, but notes that although they resemble rocks that have risen from great depths, there are still some differences: in them chromium plays only a subordinate role and nickel is not mentioned. Perhaps, he says, ilmenite, which in places occurs abundantly, may indicate the same sort of opposition between nickel and titanium observed in many iron ores, in some of the fixed stars and in sunspots. Suess says that among the many puzzles our road has so far led us, this is one of the most exciting. In not a few places diamond occurs in these pipes: always in deep simatic rocks, always in parts of the earth that had rigefied very early.

Next he deals with the geography of volcanoes. They do not show the same kind of distribution in the Atlantic region as they do in the Pacific region. In the Atlantic region one encounters 1) diffuse volcanic fields (the North Atlantic volcanic field and the Siberian traps are given as examples), 2) volcanoes along disjunctive lines such as those along the African rifts. Suess says that even in Iceland volcanic fissures tend to become grabens with time, and finally 3) group volcanoes, such as the Azores, the Canary Islands and the Cape Verde Islands.

In the Pacific region 1) the diffuse volcanic fields are barely represented. The main type of volcanism here is 2) that along disjunctive lines all along the peripheral regions of Asia, in island arcs and in the Andean edifice. Suess regrets that the observations in the Oceanides are few, but as far as the association of volcanoes with deep-sea trenches goes, they resemble the Asian types. The group volcanoes (3) in the Pacific occur in an area framed by the Oceanides, the Hawaii line and the western margin of the Americas; they are represented by such islands as the Galapagos and Easter Island.

The volcanoes of the Alpides form a class of their own according to Suess. Here one sees mixed characters. He then also discusses other smaller occurrences in Europe and Asia.

Suess finally comes to the differences in lava compositions. Here he follows his colleague in the University of Vienna Friedrich Johann Karl Becke (1855-1931), who had shown in
1902 and 1903 that two types of young volcanic rocks could be distinguished: an Atlantic- and a Pacific-type (Becke 1902, 1903). In fact, this distinction had already been made in essence before Becke: in 1892 the American petrographer Joseph Paxson Iddings (1857-1920) had first noticed the distinction in a paper, in which he had introduced the concept of consanguinity within petrographic provinces. It had been the British petrographer Alfred Harker (1859-1939), however, who first elaborated on that distinction in 1896 and showed that Iddings' alkali and sub-alkali (now called calc-alkalic or calcalkaline) groups occurred mostly in the Atlantic- and Pacifictype of continental margins (Harker had written 'coast lines') of Suess respectively, thus explicitly citing Suess' distinction of the tectonic environment (Harker 1896). Harker accordingly had suggested the terms Atlantic and Pacific 'tribes.' He had re-emphasized the distinction in 1909 in his famous book on the Natural History of Igneous Rocks (Harker 1909, especially p. 92-93). Suess in the Antlitz refers only to Becke, who is also cited by Harker (1909, p. 93, footnote 1) because, most likely, he had discussed the issue with him. Suess wrote (1909a, p. 677-678) that Becke did not distinguish these two types only on the basis of their geographic distribution, but also on a tectonic basis: the Atlantic type was characteristic of regions of in-breaks ('Einbruch) resulting from the radial element of contraction and the Pacific type was typical of regions of tangential shortening ('tangentialer Zusammenscbub). Finally Suess says that Becke's hypothesis is based on the assumption that in the Pacific magmas there is a considerable assimilation of sedimentary rocks, which would explain the greater content of $\mathrm{Ca}$ and $\mathrm{Mg}$ (Suess 1909a, p. 679). In the light of Figure 22 it is not difficult to imagine how Suess must have thought this mixing happened.

This precocious hypothesis was also forgotten until 1953, when Stille reinvented it while working on his monograph on the tectonics of the Carpathians (1953, p. 184-193; also see Stille 1954) and later applied it to the active circum-Pacific magmatism (Stille 1955, 1960). I assume he reinvented it because he gave no reference to Suess in any of his writings on this subject and during the International Geological Congress in Algiers in 1952, when he presented this idea, not one geologist who took part in the subsequent discussion (Ernst Kraus, Germany; Wilhelm Petrascheck, Austria; Emil Tröger, Germany; Silvio Vardabasso, Italy; Paul Ramdohr, Germany; Louis Glangeaud, France: see Stille 1954, p. 136-137) thought of reminding Stille that Suess had already said it half a century earlier in no equivocal form. So uninformed (or unresponsive) had become the geological community during the Dark Intermezzo!

Chapter twenty seven ends the tectonic part of Das Antlitz. der Erde, in which Suess compares the Moon with the earth, 
gives expression to his disapproval of the theory of isostasy and defines what he means by rigefaction (= 'Erstarrung'). The Moon is a part of the earth, but only of its silicate layer, not of the Nife. The face of the Moon shows repeated episodes of melting in vast areas and since it has no Nife part, Suess says that on earth, magmatism must have its sources in the layer above Nife, namely in Sima. Between the vast 'seas' on the Moon, which are nothing but large areas of melting and lava outpouring, there are wedge-shaped high areas which he compares with the terrestrial continents.

Suess has difficulty with the idea of isostasy, first, because the observations are contradictory; secondly, Bailey Willis' (1857-1949) idea of oceanic spreading, based on the compensation of the heavier oceanic floors, would have difficulty explaining the origin of the arcs of the Altaids from Lake Baykal to the Marianas. The Indian Ocean is completely surrounded with fractured continents on which terrestrial sediments come all the way to the shore and are abruptly cut by normal faults along which the ocean floors subsided. One has all the reason to believe that the bottom of the Indian Ocean houses the subsided parts of these continents. A heavier substratum would lead to spreading towards the continents and the shortening of the latter. But the continents around the Indian Ocean show no such influence. Suess says that had such an influence really existed, it would have first eliminated the foredeeps. He points out that above the deepest trenches the highest negative gravity values were measured, which is the opposite of what the theory of compensation requires. In the letter he wrote to Charles Schuchert, he summarized his final position as follows:

"First, I must declare myself a beretic in all regarding isostasy. I have in my last volume given the facts [IV-190: 608-7 which cause me to doubt anything like a deficit in gravity beneath the mountains. Faye [great French astronomer and geophysicist Hervé-ÉtienneAuguste-Albans Faye \{1814-1902\}] has always doubted it and, if I am not wrong, Professor Gilbert [Grove Karl Gilbert] seems also to partake of this view. There is not sufficient space here to enter into this question and I can only permit myself to doubt likewise whether any sinking can be caused by loading. All these loads seem trifles in comparison to the magnitude of the planet." (Suess 1911a, p. 101).

Suess finally reviews the effects of contraction. He reminds his readers that right in the beginning of his book, he had pointed out that contraction of the earth is resolved into two components at its surface: a tangential component creating the horizontal movements and a radial component creating the subsidence. He points out that Élie de Beaumont had also considered tangential movements in his version of the contraction theory, but his version required that two strong masses move towards each other and create symmetric mountain ranges. Suess had differed from him in that he assumed that the movements were asymmetric creating a difference between a foreland and a hinterland or a backland. He repeats his interpretation of foredeeps and of backfolding. Mountain-building in his theory really happens along immense thrusts, along which the distinction of tangential versus radial contraction becomes difficult to make (see also Şengör 2009). The presence of Pacific-type magmatic rocks in the Alps and the greenstone occurrences make it clear that mountain building here has deep roots. Under all large mountain ranges is a zone of overthrusting (see Şengör 2009).

From this viewpoint, rigefaction is only to be understood as cessation of mountain-building stresses. This usually happens when a nearby large area subsides, thus removing the contracting 'frame' within which folding takes place (cf. Şengör 1982). However, Suess observes that mountain ranges exhibit such immense amounts of shortening that contraction alone may not be sufficient to account for it and possibly tidal forces must be taken into account. However, he says, the Alps, in which so far the greatest amounts of shortening had been observed, do not follow the lines of the tidal forces.

In the last part of this chapter Suess allows once more the planet earth to rotate beneath his eyes and describes in sixhourly slices what comes before him. This is a summary of the entire tectonic work of 26 years.

The final chapter of Das Antlitz der Erde is simply called 'Life'. Suess' great student Theodor Fuchs (1842-1925), one of the creators of modern marine geology and the Neogene stratigraphy and one of the Viennese Giants in geology, said in his review of the Antlitz that everybody was waiting to see Suess' final verdict on Darwin's theory (Fuchs 1909). They were disappointed. Suess felt that he was no longer up to date with the immense developments that had taken place in evolutionary biology to pass a judgment. Instead he concentrated on the influence of the environment on the course of the biological evolution. This was the aspect that most interested him all his life anyway. He identified certain areas that had long remained dry land (as he had earlier done on the example of Angara-Land in v. III/1, p. 190). He interpreted these areas as refugia, asylums as he called them, for terrestrial life. During the large transgressions, terrestrial life became crowded into these areas from which it diversified away during the regressive episodes. In this context it is interesting that Suess thought that the post-Maastrichtian regression may have caused the extinction of the dinosaurs:

"The wide inundation of so many continents and the succeeding probably rather rapid retreat of the marine waters also dissipated land waters, resulting in the destruction of the large dinosaurs, the inhabitants of the swamps, rivers and lowlands, and retaining only those types of Reptilia which exist unto present day." (Suess 1911a).

He ends by pointing out that life is very closely dependent on the fortunes of the planet.

\section{A Few Final Comments on Das Antlitz der Erde}

As the reader may have noticed from my summary above, Das Antlitz der Erde is an exceedingly difficult book to read. Its figures are inadequate, even in the French edition in which the number of the figures was greatly increased. Its descriptions are very detailed. In many cases they almost force the reader to go to the original sources just to establish where one is in some detail. The language is sublime, but it was clearly written once and never again edited. The book is in need of a serious editing which it never had. It contains not only changes of interpretation in many cases, which is acceptable, but even inconsistencies in nomenclature, which is not. Not a few references are wrong and shows that they were written down from memory with no subsequent check. It gives the impression that it was written in a hurry. This is understandable, because Suess 
was busy with a hundred other things while writing most of it (let us remember that he was a member of the Imperial Parliament until 1896, his dear wife died in 1898, he continued teaching until 1901 and remained the President of the Imperial Academy of Sciences until 1911).

Yet, for all its shortcomings it was the greatest book that geology had ever seen until then and I cannot think of another to rival it since. It is a thorough review of the entire geology of the planet from the viewpoint of one particular theory of tectogenesis, namely Prévost's version of the theory of thermal contraction. Still, its facts are so good that to this day I use it in many places just to learn the geology or to have a quick overview. It gave geology a unified framework and a unity of purpose it previously never had. It was not only the synthetic conclusion of all that geology had accomplished to that day, but also a bright and penetrating beacon for its future development. It is the herald of modern geology, because it, for the first time, presented a methodology that we today use for viewing the entire planet as a whole (and other rocky planets as well). Modern techniques such as isotopic age dating, seismic reflection profiling, fault-plane solutions of earthquakes, sequence stratigraphy and many others were seamlessly fitted into his methodology of regional geology.

It was hailed by all earth scientists: geologists, paleontologists, geographers, geophysicists as an immense achievement, as the crown jewel of their science. Suess was heaped with medals, academy memberships, honorary fellowships, honorary doctorates ... from all over the world. He became undoubtedly the greatest and the most feted earth scientist alive. When Lord Kelvin's compression of the duration of earth history between 20 and $40 \mathrm{Ma}$ caused universal consternation among geologists at the end of the nineteenth and the beginning of the twentieth century, Arthur Holmes (18901965), when he was in the last 'form' in high school (so 17 or 18 , as the last, i. e. the sixth 'form' in English high schools had a duration of two years: Kevin Burke, personal communicattion, 3rd November, 2014), was given by 'Mr. J. McIntosh, a brilliant physics teacher' the first volume of the English translation of the Antlitz as consolation (Holmes 1963, p. xvi).

Yet, for all the jubilation it caused, Das Antlitz. der Erde has remained mostly unread. It is hard to read, yes, but the greatest harm may have been done by a large paper Emil Tietze published in 1917 in which he purported to review and summarize Suess' work. In reality, it was written with the purpose of belittling that work and was so full of misunderstandings, mis-statements, and non-sequiturs of a small mind that I remain baffled by how many subsequent geologists and historians of geology seem to have found it adequate to obtain an idea about what Suess had done. For anybody interested in understanding Suess, I would advise leaving Tietze untouched.

\section{Suess After the Antlitz}

After the last volume of the Antlitz, was published, only slightly more than four years were left for Suess to live. He had completed the Antlitz, when he was 79. He published four more papers until he died at the age of 83 .

The first of these papers was just a summary of the last chapter of the Antlitz and carried the same title, i.e. 'Life'. It was based on a lecture he gave on 20 ${ }^{\text {th }}$ March 1909 to the Geological Society in Vienna and was taken down stenographically from his spoken word (Suess 1909c). The second was a study on John Dee (1527-1608), the British scientist and astrologer/alchemist and adviser to Queen Elisabeth I, published in the popular magazine Österreichische Rundschau (Suess $1910 \mathrm{a}, \mathrm{b})$. This is a study purely on the history and philosophy of science and at first sight unrelated to geology. However, Suess mentions that Dee had a paper on the causes of the tides and was knowledgeable on terrestrial magnetism and geography in addition to his skills in geometry, astronomy and chemistry. But the main thrust of the paper is to show how religion and other superstitions can derail a natural scientist and how shockingly gullible they can be facing religious impostors. True to his habits, Suess' documentation of the story he tells is impeccable. His appeal to the learned world of his county to search for further documents about Dee's doings in Bohemia was surprisingly answered by the young humanist Prince Adolf Schwarzenberg (1890-1950) within the same year and Suess published the Prince's response in a later issue of the Österreichische Rundschau as an appendix to his main paper. (Suess 1910b). Dee's Bohemian connection may have been another source of interest for Suess' study.

Suess' third paper consisted of the text of a lecture given on $9^{\text {th }}$ March 1911 to the Academy of Sciences in Vienna during a celebratory meeting and reviewed the geology, geomorphology and the historical importance of the Danube (Suess 1911c).

But the fourth paper he published — his last — was of great importance from a number of viewpoints. It carries the title Über die Zerlegung der gebirgsbildenden Kraft ( $=$ On the resolution of the mountain-building force) published in 1913 (Suess 1913b). Suess introduces the paper with a defence of the theory of contraction, citing the attacks made on it in the United States and Great Britain. He says, in the United States Clarence Edward Dutton (1841-1912) was the leading adversary, whereas in England he cites the Reverend Osmond Fisher (18171914; Suess cites the first edition of his Physics of the Earth's Crust, 1881; Suess owned this book: Anonymous 1914, p. 21). Suess' main defence in the name of the contraction theory is that the assumptions made to attack its physical basis and its adequacy to account for the observations of field geology are debatable and for this conclusion he relies on Sir George Howard Darwin's (1845-1912; the second son of Charles Darwin) statements without referring to any specific work. He then reminds his reader of his division of the motions caused by contraction into a tangential and a radial one. The evidence for radial contraction is abundantly present. For the tangential movements, he cites what are believed to be active examples: both from a Karawank tunnel and from earthquakes in Alaska. He then proceeds to show how the horizontal stresses are resolved and the structures they generate. He begins with a hand sample showing crenulations and conjugate fractures reviewing their nomenclature and its history. He reminds his readers of Gabriel August Daubrée's experimental (Daubrée 1879) and Albert Heim's field observations (in Heim 1878a, b) introducing the two terms used by Daubrée: diaclase (for what we today call joints: equivalent, Suess says, to the German miners' term Gare) and paraclase (for what we call faults; his page reference to Daubrée's book as p. 257, on his own page 24 is incorrect; the correct reference is p. 352). For the horizontal diaclases the page reference he gives as p. 358 in Daubrée's 
book is correct (Suess refers to the figure on that page without saying so). Suess proposes to call these bathroclases (from the Greek $\beta a \dot{\theta} \varrho o v=$ bank). He will refer to the conjugate joints forming under shortening as diaclases.

From that he proceeds to the European foreland and discusses the conjugate faults of the foreland that he believes formed under the influence of the shortening in the Alps. Although what he did was reinvented after his death by many (e.g. Cloos 1928; Lotze 1937, 1938; van Waterschoot van der Gracht 1938 before plate tectonics; Molnar and Tapponnier 1975; Şengör 1976, after plate tectonics), these newer authors have remained ignorant of Suess' last paper, with the single exception of Stille's student Lotze (1938). Oddly, however, Lotze (1938) has Suess (1913) in his reference list, but the paper is not discussed nor referred to in the main body of the text. It clearly remained fashionable to be aware of Suess in the Dark Intermezzo, but not necessarily of what he said!

His last paper is also extremely interesting from another viewpoint. It was published in 1913, yet not a word is said in it about Wegener's theory of continental drift that had appeared the previous year. Did it remain unknown to Suess while he was writing his paper, although, as the honorary president of the Geologische Vereinigung, he must have received at least the paper published in its organ, the Geologische Rundschau? That he was no longer completely up-to-date is shown by his citation of the first edition of Reverend Osmond Fisher's Physics of the Earth's Crust (Fisher 1881), which he owned, but not its second that was very different from the first (Fisher 1889) and which the catalogue of his library does not list. Was his animated defence of the contraction theory a reaction? If so, why did he not say it openly? We know that his geologist son, Franz Eduard Suess, became not only an early convert, but one of the great geological theoreticians of continental drift. Wegener's theory would have also solved his problem of too much shortening in mountain belts for the contraction theory to deal with. Whatever the reasons, I know of no comment made by Suess about Wegener's theory. It would have been so interesting to know his opinion!

\section{CONCLUSIONS}

I mentioned above that Suess' work is hard to read; not because of his style, but because he was not allowed to publish many figures to orientate his reader since his publisher found them too costly. This defect was in part removed in the French edition, because the French editor, Emmanuel de Margerie (1862-1953), was not only a remarkable intellectual, but also a friend of the publisher Auguste Armand Colin's (1842-1900) son-in-law, the scholarly Max Leclerc (1864-1932), who himself was a great traveler and an enthusiast of geography. The two of them weighed on Monsieur Colin to agree to make no profit on this important book and he most generously consented. After Colin's death, Max Leclerc became the head of the firm and, consequently, many figures could be added to the French edition that made following the text very much easier. The English edition added some incredibly prophetic figures from Suess' own hand explaining a number of key concepts such as foredeep, vertex, backfolding, syntaxis, free and forced virgations and linking and the Spanish edition appended four maps showing the location of 3000 localities mentioned in the book. These collectively should have made Das Antlitz. der Erde more accessible, but I suppose nobody owned all four editions at once. A variorum edition is clearly needed and would not be difficult to produce, but so far nobody undertook it.

Despite the difficulty of reading especially the Antlitr, Suess' work as a whole still has a freshness that no geologist's work before him had since Hutton and Cuvier. His style was not that of a teacher, but of an explorer and a discoverer, anxious to communicate what he has found, as Bertrand Russell said of Descartes' writing style. Russell continued his characterization with the following words:

"It is easy and unpedantic, addressed to the intelligent men of the world rather than to pupils. It is moreover, an extraordinarily excellent style. It is very fortunate for modern philosophy that the pioneer had such admirable literary sense." (Russell 1945 (1972), p. 558).

The same can be said of the pioneer of modern geology, but I suppose neither Descartes nor Suess is as readily comprehensible to the intelligent men of the world as Russell seems to think if that man had little education; in both cases some previous preparation is necessary.

The narrative above I think may suffice to show how much more advanced Suess was in his geological thinking than any of his contemporaries and most of the members of the two generations of geologists that followed him during the Dark Intermezzo. He was so much farther ahead that his ideas on the origin of the large-scale features of the earth were generally thought totally implausible and the admiration heaped upon what he published was mainly because of its comprehensiveness and the unequalled learning of its author. Suess had reacted to the overly schematic, regularistic and both spatially and temporally discontinuous nature of the tectonic theories before him and created a theory of earth behaviour that was comprehensive, chaotically fluid and both spatially and temporally continuous with no hiccups in it. If his eustatic movement idea had not tied him to Prévost's version of the contraction theory, he might have come up with some form of continental drift. In fact, his theory of orogeny and rifting make much better sense in the framework of continental drift than even in his own theory of contraction and those few who understood what he had said, such as Nicolaas Wing Easton (1859-1937), Gustaaf Adolf Frederik Molengraaff (18601942), Frank Bursley Taylor (1860-1938), Reginald Aldworth Daly (1871-1957), Alexander Logie du Toit (1878-1948), Willem A. J. M. Waterschoot van der Gracht (1873-1943), Alfred Lothar Wegener (1880-1930), Émile Argand (18791940), Wilhelm Salomon-Calvi (1868-1941), Sir Edward Battersby Bailey (1881-1965), Arthur Holmes (1890-1965; we know that he read at least the first volume of the Antlitz when still in high school! See above) and his own son Franz Eduard Suess (1867-1941), became mobilists; those who did not, such as Émile Haug (1861-1927), Hans Stille (1876-1966), Leopold Kober (1883-1970), Hans Cloos (1885-1951), Rollin Thomas Chamberlin (1881-1948), Erich Haarmann (1882-1945), Charles Schuchert (1858-1942), Bailey Willis (1857-1949), Walter Bucher (1888-1965), Johannes Herman Frederik Umbgrove (1899-1954) and Reinaut Willem van Bemmelen (19041983) ignored his theoretical views and returned to the simplistic earth models of Élie de Beaumont (1798-1874) and James Dwight Dana (1813-1895) and, in the case of the theoreticians of the primary vertical tectonics, all the way back to 
Leopold von Buch (1774-1853)! The latter group, called fixists by Argand, dominated geology until the rise of plate tectonics in 1965 and that domination cost tectonics a valuable half century.

The difference between Suess and his future critics was not only about the degree of horizontal mobility of the continents they allowed. Compared with the 'mobilists' Suess himself was very much a fixist. Where he differed from his critics was predominantly in his adherence to Huttonian actualism and his refusal to assume unerring temporal and spatial regularities in geology without incontrovertible evidence. He seems to have taken the same position as Hutton as expressed in the following statement by the great Scottish pioneer:

"We have been presenting this system of this earth as proceeding with a certain regularity, which is not perhaps in nature, but which is necessary for our clear conception of the system of nature." (Hutton 1788, p. 301, emphasis is mine).

That is why I have always avoided calling his supporters 'mobilist': what characterized them was their commitment to actualism and rejection of unwarranted regularities in earth behaviour. Among those people in the twentieth century, whom I labelled 'Wegener-Argandians', there were also fixists, the most prominent of whom, J. Tuzo Wilson (1908-1993), finally converted to mobilism and in the process invented plate tectonics. The opposing school, incorporating the most prominent fixists of the twentieth century whom I collectively called the 'Kober-Stille school', after its best-known and most vociferous members, also had mobilist members, such as Rudolf Staub (1890-1961; he ended up converting to a contractionist fixism).

It was not only in tectonics that Suess' example was abandoned. His Kober-Stillean successors no longer viewed geology as an indivisible whole and the science splintered into numerous specialties making communication among specialists difficult, at times simply impossible. Geologists lost the forest for the trees. Because they have come to know more and more about less and less, they have become intolerant of criticism coming from outside their narrow sub-fields. This created a vicious cycle of ever narrowing specialties and ever increasing dogmatism and geologists lost sight of the planet. No wonder plate tectonics was invented by a non-specialist.

Narrowness and intolerance to criticism also fostered positivism. Geologists collected data to confirm their models, not to test them. To err became a blemish to be avoided at all cost. This led to an attitude that exalted mindless empiricism and deprecated theorizing. Already in 1914, Daly was complaining that the science of geology was drowning in facts and what was needed was controlled, imaginative scientific speculation (Daly 1914). This advice, disparagingly called 'arm-chair geology', was shunned during the Dark Intermezzo. Geological mapping became not only the method, but also the aim of geological research, because it became unclear in the prevalent confusion what step after the mapping is completed had to be taken (Wilson 1982). The professors gravely advised their pupils to observe, but it was left unclear what the observations were for. They quickly became buttresses for the commonly unjustified biases of their professors and geology began to stagnate. Although geophysicists were doing great and innovative work, especially the Dutch in their southeast Asian and
Caribbean colonies, geologists were unable to give them much help because of their narrow outlooks and sterile conservatism.

For the last three-and-a-half decades of the twentieth century, it seemed as if Wilson's 1965 paper had changed all that and the literature of the seventies and eighties indeed gave hope that a robust edifice of theoretical geology would soon emerge leading to understanding the overall evolution of the earth. However, the rise of high-precision instruments to analyse rocks and minerals and the widespread availability of powerful computers have again made geologists to avoid 'controlled scientific imagination'. One forgot that the aim of theoretical geology is not to reduce it to chemistry and physics or to some engineering formula, as so nicely put by M. King Hubbert (1903-1989) already in his Presidential Address to the Geological Society of America aptly entitled Are we retrogressing in science'.

"Instead of being students of the earth, geologists bave tended to become students of minerals, of rocks, of ore deposits, of coal, of petroleum, of strata, of fossils, of deformational structures, of volcanoes, of erosion and landforms, and of the physics and chemistry of the earth." (Hubbert 1963, p. 377).

Geology's job is to unravel the history of the planet by understanding what happened. This cannot be achieved without understanding the processes, but such an understanding in turn cannot be obtained by simply assuming 'a spherical planet'. Earth history has been extremely complex: as much as a historian cannot understand the events in human history by studying sociology and psychology only and ignoring historical documents, so a geologist cannot understand earth history by considering it a problem in physics or engineering.

It was the comprehensive view of geology that we should have learned from Suess. His incredible success is the best guarantee of the soundness of his method which consisted of approaching the geological processes with a vast reserve of knowledge of regional geology and with a mind ready to conceive hypotheses and to discard them when they come into conflict with good observations. He anticipated so closely the understanding of the earth's structure and evolution we have today that one feels that he would have come up with something not too dissimilar to our current views had he had an accurate view of the ocean floors and the distribution of the earthquakes. With his prodigious memory, vast knowledge of the world regional geology and great intellectual courage, J. Tuzo Wilson very much walked in Suess' footsteps and ended up inventing plate tectonics. Even when Wilson was still a fixist, his tectonic ideas had nevertheless been amazingly similar to those of Suess.

I wish to end this eulogy to Suess with the expression of my hope that it will be read not only as a contribution to history of science, but also as a support for careful attention to world regional geology when one is attempting to understand geological proceses and geological history.

\section{ACKNOWLEDGEMENTS}

I thank Brendan Murphy for inviting this paper and waiting for it patiently. Dr.-Ing. Wolfgang Gasche, great-grandson of Eduard Suess, sent me a copy of the catalogue of Suess' library, always informed me of activities concerning Suess and provided enthusiastic help whenever I called upon him. I am deeply honoured to be considered a friend of the Suess family. My scholarly friend and colleague Boris Natal'in has been a ready source of knowledge in all matters concerning his great country Rus- 
sia. Robin Cocks and Şevket Şen helped with palaeontological matters. The head librarian of the Austrian Geological Survey, Thomas Hofmann, helped with finding certain references and by keeping me up-to-date on Suess-related activities. My historian friend Johannes Seidl and the former head of the Survey library Tillfried Cernajsek also helped by keeping me informed of the most recent Suess research. Nalan Lom kindly read the text and checked the references upon my request. Finally I must express my profound gratitude to my two reviewers: Paul F. Hoffman and Robert Raeside. They expended a huge effort to save me from many errors of omission and comission and to make this paper more presentable.

\section{REFERENCES}

Abel-Rémusat, J.-P., 1820, Histoire de la Ville de Khotan, tirée des Annales de la Chine et traduite du Chinois; Suivie de Recherches sur la Substance Minérale Appelée par les Chinois PIERRE DU IU et sur le JASPE des Anciens: Imprimerie de Doublet, Paris, XVI + 240 p.

Abel-Rémusat, J.-P., 1836, Foë Kouë Ki ou Relation des Royaumes Bouddhiques: Voyage dans la Tartarie, dans l'Afghanistan et dans l'Inde, exécuté a la fin du IVe siècle, par Chÿ Fä Hian. Traduit du Chinois et commenté par M. Abel Rémusat. Ouvrage Posthume revu, complété, et augmenté d'éclaircissements nouveaux par MM. Klaproth et Landresse: A l'Imprimerie Royale, Paris, LXVI $+[2]+424$ p. +5 foldouts.

Allen, M.B., Şengör, A.M.C., and Natal'in, B.A., 1995, Junggar, Turfan, and Alakol basins as Late Permian to ?Early Triassic extensional structures in a sinistral shear zone in the Altaid orogenic collage, Central Asia: Journal of the Geological Society, v. 152, p. 327-338, http://dx.doi.org/10.1144/gsigs.152.2.0327.

Ampferer, O., and Hammer, W., 1911, Geologischer Querschnitt durch die Ostalpen vom Allgäu zum Gardasee: Jahrbuch der kaiserlich und königlichen Geologischen Reichsanstalt, v. 61, p. 531-710, plates XXXII-XXXIV.

Andreae, A., 1892a, Eine theoretische Reflexion über die Bildung der Rheinspalte und Versuch einer Erklärung, warum die Rheinthalebene als schmaler Graben in der Mitte des Schwarzwald-Vogesenhorstes einbrach: Verhandlungen des Naturhistorisch-Medizinischen Vereins zu Heidelberg, neue Folge, v. 4, p. $16-24$

Andreae, A., 1892b, Beiträge zur Kenntniss des Rheinthalspaltensystems: Verhandlungen des Naturhistorisch-Medizinischen Vereins zu Heidelberg, neue Folge, v. 4 , p. $47-55$.

Andrews, R.C., 1932, The New Conquest of Central Asia, in Reeds, C.A., ed., Natural History of Central Asia, v. I, Central Asiatic Expeditions: The American Museum of Natural History, New York, 678 p.

Anonymous, 1851, Carlsbad und Seine Umgebungen-Kürzester und Zuverlässigster Wegweiser für Curgäste und Reisende beim Besuche dieses Curortes: A.C. Kronberg'sche Buchhandlung, Carlsbad und Prag, 161 p.

Anonymous, 1914, Katalog der Bibliothek Eduard Suess: Im Selbstverlag der Erben Eduard Suess, Druck von Paul Gerin, Wien, 91 p.

Anonymous, 1989, Regional Geology of Gansu Province: People's Republic of China, Ministry of Geology and Mineral Resources, Geological Memoirs, series 1, no. 19, Geological Publishing House, Beijing, XI+692 p.+9 geological maps in box.

Anonymous, 1991, Regional geology of Nei Mongol Autonomous Region: Bureau of Geology and Mineral Resources of the Nei Mongol Autonomous Region, People's Republic of China Ministry of Geology and Mineral Resources, Geological Memoirs, Series 1, No 25, Geological Publishing House, Beijing, 728 p. (Chinese with English abstract).

Argand, É., 1912, Sur la segmentation tectonique des Alpes occidentales: Bulletin de la Société vaudouise des Sciences Naturelles, v. 48, p. 345-356.

Argand, É., 1916, Sur l'arc des Alpes Occidentales: Eclogae Geologicae Helvetiae, v. 14, p. 145-191.

Argand, É., 1924, La Tectonique de l’Asie: Congrés Géologiques International, Comptes Rendus de la XIIme session, Premier Fascicule, H. Vaillant-Carmanne, Liège, p. 171-372.

Argand, É., 1928, Carte Tectonique de l'Eurasie: Service Géologique de Belgique, Bruxelles, 1 sheet.

Bacon, F. (Sir), 1620 (1863), Novum Organum, in Spedding, J., Ellis, R.L., and Heath, D.D., eds., 1863, The Works of Francis Bacon, v. 1: Riverside Press, Cambridge, $539 \mathrm{p}$.

Bailey, E.B. (Sir), and McCallien, W.J., 1960, Some aspects of the Steinmann trinity, mainly chemical: Quarterly Journal of the Geological Society, v. 116, p. 365-395, http://dx.doi.org/10.1144/gsigs.116.1.0365.

Bamber, J.L., Riva, R.E.M., Vermeersen, B.L.A., and LeBrocq, A.M., 2009, Reassessment of the potential sea-level rise from a collapse of the West Antarctic Ice Sheet: Science, v. 324, p. 901-903, http://dx.doi.org/10.1126/science.1169335.

Barrande, J., 1850, Graptolites de Bohême-extrait du Systême Silurien de la Bohême: Privately printed, Prague, $\mathrm{VI}+[\mathrm{I}]+74$ p. +4 plates and captions

Basse, E., 1932, Paléontologie de Madagascar, XVIII: Faune malacologique du Crétacé supérieur du Sud-Ouest de Madagascar: Annales de Paléontologie, v. 21, p. 91-168.
Battaglia, M., Troise, C., Obrizzo, F. Pingue, F., and De Natale, G., 2006, Evidence for fluid migration as the source of deformation at Campi Flegrei caldera (Italy): Geophysical Research Letters, v. 33, L01307, http://dx.doi.org/ 10.1029/2005GL024904.

Bausum, A., 2000, Dragon Bones and Dinosaur Eggs-A Photobiography of Explorer Roy Chapman Andrews: National Geographic Society, Washington, D.C., 64 p.

Becke, F., 1902, Das böhmische und das amerikanische Eruptivgebiet, ein chemischpetrographischer Vergleich: Verhandlungen der Gesellschaft Deutscher Naturforscher und Ärzte, 74. Versammlung zu Karlsbad, 2. Theil, Sitzungen der naturwissenschaftlichen Abtheilung, 22 September, p. 125-126.

Becke, F., 1903, Die Eruptivgebiete des böhmischen Mittelgebirges und der amerikanischen Andes_-atlantische und pazifische Sippe der Eruptivgesteine: Tschermaks Mineralogische und Petrographische Mitteilungen, v. 22, p. 209-265.

Benali, H., undated, Les Mineralisations Associees aux Roches Magmatiques Tertiaires du Nord de l'Algerie (Typologie, Petrologie, Cadre Geodynamique, et Implications Metallogeniques): https://www.google.com.tr/webhp?sourceid $=$ chrome-instant $\&$ ion $=1 \&$ espv $=2 \&$ ie $=U T F-8 \# q=$ Tifaraouin + volcano last viewed on 6th October 2014.

Berkey, C.P. and Morris, F.K., 1924, Basin structures in Mongolia: Bulletin of the American Museum of Natural History, no. 51, p. 103-127.

Berkey, C.P., and Morris, F.K., 1927, Geology of Mongolia-A Reconnaisance Report Based on the Expeditions of the Years 1922-1923. Natural History of Central Asia, v. II, Central Asiatic Expeditions, Roy Chapman Andrews, leader: American Museum of Natural History, New York, xxxi+475 p.

Bertrand, M., 1884, Rapports de structure des Alpes de Glaris et du bassin houiller du Nord: Bulletin de la Société Géologique de France, série 3, v. 12, p. 318-330.

Bertrand, M., 1887, La chaîne des Alpes et la formation du continent Européen: Bulletin de la Société Géologique de France, série 3, v. 15, p. 423-447.

Billi, A., Gambini, R., Nicolai, C., and Storti, F., 2007, Neogene-Quaternary intraforeland transpression along a Mesozoic flatform-basin margin: The Gargano fault system, Adria, Italy: Geosphere, v. 3, p. 1-15, http://dx.doi.org/ 10.1130/GES00057.1

de Blainville, H.M.D., 1825, Manuel de Malacology et de Conchyliologie: F. G. Levrault, Paris und and Strasbourg, VII+664 p. +5 plates.

de Blainville, H.M.D., 1827, Manuel de Malacology et de Conchyliologie-Planches: F. G. Levrault, Paris und and Strasbourg, $[1]+109$ plates.

de Böckh, H., Lees, G.M., and Richardson, F.D.S., 1929, Contribution to the stratigraphy and tectonics of the Iranian ranges, in Gregory, J.W., ed., The Structure of Asia: Methuen \& Co., London, p. 58-176 +23 plates.

Bodnar R.J., Cannatelli, C., De Vivo, B., Lima, A., Belkin, H.E., and Milia, A., 2007, Quantitative model for magma degassing and ground deformation (bradyseism) at Campi Flegrei, Italy: Implications for future eruptions: Geology, v. 35, p. 791-794, http://dx.doi.org/10.1130/G23653A.1.

Boissonnade, E., 1971, Conrad Kilian: France-Empire, Paris, 430 p.

Boulton, S.J. and Stewart, I.S., in press, Holocene coastal notches in the Mediterranean region: indicators of palaeoseismic clustering?: Geomorphology, http://dx.doi.org/10.1016/j.geomorph.2013.11.012.

Bravais, A., 1842, Sur les lignes d'ancien niveau de la mer dans le Finnmark: Comptes Rendus hébdomadaire de l'Academie des Sciences de Paris, v. 10, p. 817-849.

Brongniart, A., 1828a, Histoire de Végétaux Fossiles, ou Recherches botaniques et Géologiques sur les Végétaux Renfermés les Diverses Couches du Globe: G. Dufour et Ed. d'Ocagne, Paris and Amsterdam, v. 1, xij+488 p.

Brongniart, A., 1828b, Histoire de Végétaux Fossiles, ou Recherches botaniques et Géologiques sur les Végétaux Renfermés les Diverses Couches du Globe: G. Dufour et Ed. d'Ocagne, Paris and Amsterdam, v. 1, Atlas, 166 plates.

Brongniart, A., 1828c, Prodrome d'une Histoire des Végétaux Fossiles: Levrault, Paris and Strasbourg, viij +223 p.

Brooks, A.H., 1906, The Geography and Geology of Alaska-A Summary of Existing Knowledge with a section on Climate by Cleveland Abbe, Jr. and a topographic map and description thereof by R. U. Goode: United States Geological Survey, Professional paper No. 45, Series B. Descriptive Geology, 75, F. Geography, 46, Government Printing Office, Washington, D. C., 327 p. +34 plates (of which one foldout map in back pocket).

Brown, F., 1885, Assyriology-Its Use and Abuse in Old Testament Study: Charles Scribner, New York, [i] +96 p.

Bucher, W.H., 1933, Deformation of the Earth's Crust-An Inductive Approach to the Problems of Diastrophism: Princeton University Press, Princeton, xii +518

Bucher W.H., 1956a, Role of gravity in orogenesis: Geological Society of America Bulletin, v. 67, p. 1295-1318, http://dx.doi.org/10.1130/0016-7606(1956)67 [1295:ROGIO]2.0.CO;2

Bucher, W.H., 1956b, Modellversuche und Gedanken über das Wesen der Orogenese, in Lotze, F., ed., Geotektonisches Symposium zu Ehren von Hans Stille: Ferdinand Enke, Stuttgart, p. 396-410. 
Bucher, W.H., 1963, An experiment on the role of gravity in orogenic folding: Geologische Rundschau, v. 52, p. 804-810, http://dx.doi.org/10.1007/BF01821156.

Burchfiel, B.C., 1987, Zwischengebirge, in Seyfert, C., ed., The Encyclopedia of Structural Geology and Plate Tectonics: Van Nostrand Reinhold Company, New York, p. 846-849, http://dx.doi.org/10.1007/3-540-31080-0_126.

Burke, K., 2001, Origin of the Cameroon Line of Volcano-Capped Swells: The Journal of Geology, v. 109, p. 349-362, http://dx.doi.org/10.1086/319977.

Burke, K., and Dewey, J.F., 1974, Two plates in Africa during the Cretaceous? Nature, v. 249, p. 313-316, http://dx.doi.org/10.1038/249313a0.

Burke, K., and Şengör, A.M.C., 1986, Tectonic escape in the evolution of the continental crust, in Barazangi, M., and Brown, L., eds., Reflection Seismology: The Continental Crust: Geodynamics Series, v. 14, American Geophysical Union, Washington, D.C., p. 41-53, http://dx.doi.org/10.1029/GD014p0041.

Burke, K., and Şengör, A.M.C., 1988, Ten metre global sea-level change associated with South Atlantic Aptian salt deposition: Marine Geology, v. 83, p. 309-312, http://dx.doi.org/10.1016/0025-3227(88)90064-3

Cadisch, J., Leupold, W., Eugster, H., and Brauchli, R., 1919, Geologische Untersuchungen in Mittelbünden: Vierteljahrsschrift der Naturforschenden Gesellschaft in Zürich, v. 66 (Heim Festschrift), p. 359-417 +one foldout map.

Celsius, A., 1744, Oratio de Mutationibus Generalioribus quae in Superficie Corporum Coelestium Contingunt habita Upseliae, Die XXII Junii, Anni MDCCXLIII in solemni promotione magisteriali, in, Linneaus, C., ed., Oratio de Telluris Habitabilis Incremento. Et Andreae Celsii ... Oratio de Mutationibus Generalioribus quae in superficie corporum coelestium contingunt: Cornelium Haak, Lugduni Batavorum, p. 85-104.

Chambers, R., 1848, Ancient Sea Margins As Memorials of Changes in the Relative Level of Sea and Land: W. \& R. Chambers, Edinburgh; W.S. Orr \& Co., London, vi +337 p. +1 p. of corrigenda.

Clark, P.U., Mitrovica, J.X., Milne, G.A., and Tamisiea, M.E., 2002, Sea-level fingerprinting as a direct test for the source of global meltwater pulse IA: Science, $\mathrm{v}$ 295, p. 2438-2441, http://dx.doi.org/10.1126/science.1068797.

Cleve, P.T., 1871, On the geology of the north-eastern West India Islands: Kungliga Svenska Vetenskaps-Akademiens Handlingar, v. 9, no. 12, 48 p. +1 plate

Cloos, H., 1928, Bau und Bewegung der Gebirge in Nordamerika, Skandinavien und Mitteleuropa-Forschungen in den Jahren 1924 bis 1927, ausgeführt mit Unterstützung der Notgemeinschaft der deutschen Wissenschaft, in Soergel, W. Fortschritte der Geologie und Paläontologie, v. 7, issue 21, Gebrüder Borntraeger, Berlin, VIII +p. 241-327 + 5 plates.

Collet, L.W., 1935, The Structure of the Alps, second edition: Edward Arnold, London, $x v i+304$ p. +4 foldouts +10 photographic plates.

Comité Géologique de Russie, 1900, Aperçu des Explorations Géologiques et Minières le long du Transsibérien: Exposition Universelle de 1900 à Paris, Comité du Chemin de Fer Transsibérien, St.-Pétersbourg, XIII+200 p.

Croll, J., 1875, Climate and Time in their Geological Relations: A Theory of Secular Changes of the Earth's Climate: Daldy, Tsibster \& Co., London, xvi+[ii] +577 p. +7 plates. +1 foldout coloured map.

Croll, J., 1885, Climate and Time in their Geological Relations: A Theory of Secular Changes of the Earth's Climate, second edition: Adam and Charles Black, Edinburgh, xvi+[ii] +577 p. +7 plates. +1 foldout coloured map.

Cross, W., 1894, Pikes Peak, Colorado: U.S. Geological Survey Geological Atlas, Folio 7, 8 p., 5 maps

Daly, R.A., 1906, The nomenclature of the North American Cordillera between the 47th and 53rd parallels of latitude: The Geographical Journal, v. 27, p. 586-606, http://dx.doi.org/10.2307/1776294

Daly, R.A., 1914, Igneous Rocks and Their Origin: McGraw-Hill, New York, $\mathrm{xix}+563 \mathrm{p}$

Dana, J.D., 1863, Manual of Geology: Treating of the Principles of the Science with special reference to American Geological History, for the use of colleges, academies and schools of science: Theodore Bliss \& Co., Philadelphia, xvi+798 p.

Dana, J.D., 1872, Green Mountain geology: on the quartzite: American Journal of Science, 3 rd series, v. 3, p. $250-256$.

Dana, J.D., 1875, Manual of Geology—Treating the Principles of the Science with special reference to American Geological History, second edition: Ivison, Blakeman, Taylor, and Co., New York, xvi+828 p.

Darwin, C. (1859), On the Origin of Species by Means of Natural Selection: John Murray, London, ix +513 p. +one plate on 2 pages.

Daubrée, A., 1879, Études Synthetiques de Géologie Expérimentale: Dunod, Paris, III +828 p.

Dawson, G.M., 1897, Physical Geography and Geology: in Handbook of CanadaBritish Association for the Advancement of Science Toronto Meeting 1897: Publication Committee of the Local Executive, Toronto, p. 3-48+1 coloured plate at the back of the book.

Delitzsch, F., 1903, Babel und Bibel—Ein Vortrag/Zweiter Vortrag über Babel und Bibel/Babel und Bibel—Ein Ausblick [3 lectures in one volume]: J. C. Hinrich'sche Buchhandlung, Leipzig, 78 p. +50 p. +75 p.

Dickinson, W.R., 2001, Paleoshoreline record of relative Holocene sea levels on
Pacific islands: Earth-Science Reviews, v. 55, p. 191-234, http://dx.doi.org/ 10.1016/S0012-8252(01)00063-0.

Dickman S.R., and Williams, D.R., 1981, Viscoelastic membrane tectonics: Geophysical Research Letters, v. 8, p. 199-202, http://dx.doi.org/10.1029/ GL008i003p00199.

Diener, C., 1891, Der Gebirgsbau der Westalpen: F. Tempsky, Vienna and Prague, F Freytag, Leipzig, $\mathrm{V}+243$ p. +2 foldout maps.

Diener, C., 1914, Gedächtnisrede: in, Gedenkfeier für Eduard Sueß, Mitteilungen der Geologischen Gesellschaft in Wien, v. 7, p. 9-24, p. 26-32.

Dillmann, [C.F.] A., 1886, Die Genesis, 5th edition (kurzgefaßtes exegetisches Handbuch 11. Lieferung): S. Hirzel, Leipzig, XXII+472 p.

Dubois, M., 1891, Examen de la Géographie de Strabon—Étude Critique de la Méthode et des Sources: Imprimerie Nationale, Armand Colin et Cie, Paris, $\mathrm{XXVI}+390 \mathrm{p}$

Dvorak, J.J., and Berrino, G., 1991, Recent ground movement and seismic activity in Campi Flegrei, southern Italy: Episodic growth of a resurgent dome: Journal of Geophysical Research, v. 96, p. 2309-2323, http://dx.doi.org/10.1029/ 90JB02225.

Emmons, S.F., Cross, W., and Eldridge, G.H., 1896, Geology of the Denver Basin in Colorado: United States Geological Survey Monograph 27, 556 p.

England, P., and McKenzie, D., 1982, A thin viscous sheet model for continental deformation: Geophysical Journal International, v. 70, p. 295-321, http://dx.doi.org/10.1111/j.1365-246X.1982.tb04969.x.

England, P., and McKenzie, D., 1983, Correction to: A thin viscous sheet model for continental deformation: Geophysical Journal International, v. 73, p. 523-532, http://dx.doi.org/10.1111/j.1365-246X.1983.tb03328.x.

Ernst, W.G., and Dal Piaz, G.V., 1978, Mineral parageneses of eclogitic rocks and related mafic schists of the Piemonte ophiolite nappe, Breuil-St. Jacques area, Italian Western Alps: American Mineralogist, v. 63, p. 621-640

Felder, C., 1964, Erinnerungen eines Wiener Bürgermeisters: Forum Verlag, Vienna, $400 \mathrm{p}$.

Finkel, I., 2014, The Ark Before Noah—Decoding the Story of the Flood: Nan A. Talese, Doubleday, New York, []$+421+[1]$ p. +2 -page map.

Fisher, O., 1881, Physics of the Earth's Crust: Macmillan and Co., London, xiv +299

Fisher, O., 1889, Physics of the Earth's Crust, second edition, altered and enlarged: Macmillan and Co., London, xvi +391 p. +60 p.

Flamand, G.B.M., 1900, Une mission d'exploration scientifique au Tidikelt—Aperçu général sur les régions traversées: Annales de Géographie, v. 9, p. 233-242, plate IX.

Fuchs, T., 1909, Das Antlitz der Erde, (Schluß) II. Das Werk selbst: Neue Freie Presse Morgenblatt 16245, 11 November 1909, p. 21-23.

Gallenkamp, C., 2001, Dragon Hunter-Roy Chapman Andrews and the Central Asiatic Expeditions: Penguin Books, New York, xxiv +344 p. + numerous unnumbered photographic plates.

Gèze, B., de Sitter, L.U., and Trümpy, R., 1952, Sur le sens de déversement des nappes de la Montagne Noir: Bulletin de la Société Géologique de France, 6th series, v. 2 , p. $491-534$

Gilman, D.C., 1872, I. Annual Address. Subject: The last ten years of geographical work in this country: Journal of the American Geographical Society, v. 3, p. 111-133, http://dx.doi.org/10.2307/196414.

Greenough, G.B., 1834, Address delivered at the Anniversary Meeting of the Geological Society, on the 21st of February 1834: Proceedings of the Geological Society London, v. II, 1833-1834, no. 35, p. 42-70.

Groskurd, C.G., 1831a, Strabons Erdbeschreibung in Siebenzehn Büchern-Nach Berichtigtem Griechischen Texte unter Begleitung Kritischer und Erklärender Anmerkungen, erster Theil: Nicolaische Buchhandlung Berlin and Stettin, XCIV +590 p. +1 foldout plate.

Groskurd, C.G., 1831b, Strabons Erdbeschreibung in Siebenzehn Büchern-Nach Berichtigtem Griechischen Texte unter Begleitung Kritischer und Erklärender Anmerkungen, zweiter Theil: Nicolaische Buchhandlung Berlin and Stettin, $\mathrm{VI}+634 \mathrm{p}$

Groskurd, C.G., 1833, Strabons Erdbeschreibung in Siebenzehn Büchern-Nach Berichtigtem Griechischen Texte unter Begleitung Kritischer und Erklärender Anmerkungen, dritter Theil: Nicolaische Buchhandlung Berlin and Stettin, 464

Groskurd, C.G., 1834, Strabons Erdbeschreibung in Siebenzehn Büchern-Nach Berichtigtem Griechischen Texte unter Begleitung Kritischer und Erklärender Anmerkungen, vierter Theil das Register enthaltend: Nicolaische Buchhandlung Berlin and Stettin, $456 \mathrm{p}$.

Halm, J.K.E., 1935, An astronomical aspect of the evolution of the earth (Presidential Address, session 1934-1935): Journal of the Astronomical Society of South Africa, v. 4, p. 1-28.

Handy, M.R., Ustaszewski, K., and Kissling, E., 2015, Reconstructing the Alps-Carpathians-Dinarides as a key to understanding switches in subduction polarity, slab gaps and surface motion: International Journal of the Earth sci- 
ences (Geologische Rundschau), v. 105, p. 1-26, http://dx.doi.org/10.1007/ s00531-014-1060-3.

Haq, B.U., 2014, Cretaceous eustasy revisited: Global and Planetary Change, v. 113, p. 44-58, http://dx.doi.org/10.1016/j.gloplacha.2013.12.007.

Haq, B.U., and Al-Qahtani, A.M., 2005, Phanerozoic cycles of sea-level change on the Arabian Platform: GeoArabia, v. 10, p. 127-160.

Haq, B.U., and Schutter, S.R., 2008, A chronology of Paleozoic sea-level changes: Science, v. 322, p. 64-68, http://dx.doi.org/10.1126/science.1161648.

Haq, B.U., Hardenbol, J., and Vail, P.R., 1987, Chronology of Fluctuating Sea Levels since the Triassic: Science, v. 235, p. 1156-1167, http://dx.doi.org/10.1126/science.235.4793.1156.

Harker, A., 1896, The natural history of igneous rocks: I. Their geographical and chronological distribution: Science Progress, v. 6, p. 12-33.

Harker, A., 1909, The Natural History of Igneous Rocks: Methuen \& Co., London, $\mathrm{xv}+[]+384$ p. +2 plates

von Hauer, F. (Ritter), 1875, Die Geologie und ihre Anwendung auf die Kenntnis der Bodenbeschaffenheit der Österr.-Ungar. Monarchie: Alfred Hölder, Vienna, VIII+681 p

Heim, A., 1878a, Untersuchungen über den Mechanismus der Gebirgsbildung im Anschluss an die Geologische Monographie der Tödi-Windgällen-Gruppe, v. II: Benno Schwabe, Basel, i+246 p.

Heim, A., 1878b, Untersuchungen über den Mechanismus der Gebirgsbildung im Anschluss an die Geologische Monographie der Tödi-Windgällen-Gruppe, Atlas: Benno Schwabe, Basel, xvii plates.

Hempel, S., 2007, The Strange Case of the Broad Street Pump-John Snow and the Mystery of Cholera: University of California Press, Berkeley and Los Angeles, viiit [ii] $+321 \mathrm{p}$

Heritsch, F., 1927, Die Deckentheorie in den Alpen (Alpine Tektonik 1905-1925), in Soergel, W., ed..: Fortschritte der Geologie und Palaeontologie, Gebrüder Borntraeger, Berlin, p. IV+ p. 75-210.

Heritsch, F., 1929, The Nappe Theory in the Alps (Alpine Tectonics, 1905-1928), translated by P.G.H. Boswell: Methuen \& Co., London, 228 p.

Higgins, A.K., Soper, N.J., and Leslie, A.G., 2000, The Ellesmerian and Caledonian orogenic belts of Greenland: Polarforschung, v. 68, p. 141-151.

Hilber, V., 1915, Eduard Suess: Mitteilungen des Naturwissenschaftlichen Verein für Steiermark, v. 51, p. 3-7+1 portrait.

Hlustik, A., 1990, Bohemian biographies II: International Organization of Paleobotany Newsletter, no. 41 (April 1990), p. 6

Hoernes, R., 1900, Die vorpontische Erosion: Sitzungsberiche der kaiserlichen Akademie der Wissenschaften-mathematisch-naturwissenschaftliche Klasse, v. 109 Part I, p. 811-857.

von Höhnel, L. (Ritter), 1888, Die Expedition des Grafen Teleki in das Gebiet des Kilimandscharo und Kenia: Mittheilungen der kaiserlichen und königlichen Geographischen Gesellschaft in Wien, v. 31, p. 353-375 and p. 441-471.

von Höhnel, L. (Ritter), 1889, Die Afrika-Reise des Grafen Samuel Teleki: Mittheilungen der kaiserlichen und königlichen Geographischen Gesellschaft in Wien, v. 32 (of the new series v. 22), p. 533-564

von Höhnel, L. (Ritter), 1890a, Zum Rudolf-See und Stefanie-See: Schriften des Vereins zur Verbreitung Naturwissenchaftlicher Kenntnisse in Wien, v. 30, p. 221-309.

von Höhnel, L. (Ritter), 1890b, Bergprofil Sammlung während Graf S. Telekis Afrika Expedition 1887-88: Militär- Geographisches Institut, Wien, 1 Blatt Vorwort, 1 gefaltete farbige Indexkarte 1:1,370.000 und 34 meist gefaltete Profildarstellungen, 1-30 und I-IV.

von Höhnel, L. (Ritter), 1890c, Ostäquatorial-Afrika zwischen Pangani und dem neuentdeckten Rudolf-See: Ergebnisse der Graf S. Telekischen Expedition 1887-1888. Ergänzungsheft No. 99 zu “Petermanns Mitteilungen” p. 1-44+ 3 foldout plates.

von Höhnel, L. (Ritter), 1891, Orographisch-hydrographische Skizze des Forschungsgebietes der Graf Samuel Teleki'schen Expedition 1887-1888, in: von Höhnel, L. (Ritter), Rosiwal, A., Toula, F., and Suess, E., Beiträge zur Geologischen Kenntniss des Östlichen Afrika. Denkschriften der Mathematisch-Naturwissenschaftlichen Klasse der Kaiserlichen Akademie der Wissenschaften, v. 58 , 140 p. +6 foldout plates +2 photomicrografic plates.

von Höhnel, L. (Ritter), 1892, Zum Rudolph-See und Stephanie-See-Die Forschungsreise des Grafen Samuel Teleki in Ost-Aequatorial-Afrika 1887-1888: Alfred Hölder, Vienna, XVIII +877 p. +1 portrait as frontispiece +2 coloured foldout maps.

von Höhnel, L. (Ritter), 1926, Mein Leben zur See, auf Forschungsreisen und bei Hofe-Erinnerungen eines Osterreichischen Seeoffiziers (1857-1909): Reimar Hobbing, Berlin, 379 p. +1 Portrait as frontispiece.

von Höhnel, L. (Ritter), Rosiwal, A., Toula, F., and Suess, E., 1891, Beiträge zur Kenntniss des Östlichen Afrika. Denkschriften der Mathematisch-Naturwissenschaftlichen Klasse der Kaiserlichen Akademie der Wissenschaften, v. 58, p. $447-584+6$ plates (some foldout) +4 photographic plates

Holmes, A., 1963, Introduction, in Rankama, K., ed., The Geologic Systems-The
Precambrian v. 1: Interscience Publishers, A Division of John Wiley \& Sons, New York, p. xi-xxiv.

Hsü, K.J., Ryan, W.B.F., and Cita, M.B., 1973, Late Miocene desiccation of the Mediterranean: Nature, v. 242, p. 240-244, http://dx.doi.org/10.1038/ $242240 \mathrm{a} 0$.

Hsü, K.J., Montadert, L., Bernoulli, D., Cita, M.B., Erickson, A., Garrison, R.E., Kidd, R.B., Mèlierés, F., Müller, C., and Wright, R., 1977, History of the Mediterranean salinity crisis: Nature, v. 267, p. 399-403, http://dx.doi.org/ $10.1038 / 267399 \mathrm{a} 0$.

Hubbert, M.K., 1963, Are we retrogressing in science? (Address as Retiring President of The Geological Society of America): Geological Society of America Bulletin, v. 74 , p. $365-378$

Hubbert, M.K., and Rubey, W.W., 1959, Role of fluid pressure in mechanics of overthrust faulting: Geological Society of America Bulletin, v. 70, p. 115-166, http://dx.doi.org/10.1130/0016-7606(1959)70[115:ROFPIM]2.0.CO;2.

de Humboldt, A. (Baron), 1823, Essai Géognostique sur le Gisement des Roches dans les Deux Hémisphères: F. G. Levrault, Paris, viij + 379 p.

de Humboldt, A. (Baron), 1831, Fragmens de Géologie et de Climatologie Asiatiques, tome premier: Gide, A. Pihan Delaforest, Delaunay, Paris, 309 p.

de Humboldt, A. (Baron), 1843, Asie Centrale - Recherches sur les Chaînes des Montagnes et la Climatologie Comparée, tome premier: Gide, Paris, LVIII+ $571 \mathrm{p}$.

Hundt, R., 1917, Eduard Suess 1831-1914: Geographischer Anzeiger, 18. Jahrgang, Heft 7, p. 169-173 + frontispiece.

Hutton, J., 1788, Theory of the Earth; or an Investigation of the Laws observable in the Composition, Dissolution, and Restoration of Land upon the Globe: Transactions of the Royal Society of Edinburgh, v. 1, p. 209-304, http://dx.doi.org/10.1017/S0080456800029227.

Issel, A., 1883, Le Oscillazioni Lente del Suolo o Bradisismi Saggio di Geologia Storica: Atti della R. Università di Genova, v. 5, 422 p. +1 errata sheet +1 coloured foldout map.

Jeffreys, H. (Sir), 1931, On the mechanics of mountains: Geological Magazine, v. 68 p. 435-442, http://dx.doi.org/10.1017/S0016756800097545.

Jeffreys, H. (Sir), 1935, Earthquakes and Mountains: Methuen \& Co., London, X+ $[\mathrm{i}]+183 \mathrm{p}$

Jeffreys, H. (Sir), 1976, The Earth-Its Origin History and Physical Constitution, sixth edition: Cambridge University Press, Cambridge, xii+574 p.

Jones, D.L., Silberling, N.J., and Hillhouse, J., 1977, Wrangellia — a displaced terrane in northwestern North America: Canadian Journal of Earth Sciences, v. 14, p. 2565-2577, http://dx.doi.org/10.1139/e77-222.

Jordan, T.E., and Allmendinger, R.W., 1986, The Sierras Pampeanas of Argentina: A modern analogue of Rocky Mountain foreland deformation: American Journal of Science, v. 286, p. 737-764, http://dx.doi.org/10.2475/ajs.286.10.737.

Julien, S., 1857, Mémoirs sur les Contrées Occidentales, Traduits du Sanscrit en Chinois, en l'An 648 par Hiouen-Thsang, et du Chinois en Français par Stanislas Julien, v. 1: Imprimerie Impériale, Paris, LXXVIII+ $493 \mathrm{p}+1$ foldout map.

Julien, S., 1858, Mémoirs sur les Contrées Occidentales, Traduits du Sanscrit en Chinois, en l'An 648 par Hiouen-Thsang, et du Chinois en Français par Stanislas Julien, v. 2: Imprimerie Impériale, Paris, XIX+ 576 p. +1 foldout map.

Karpinsky, A.P., 1883, Zamechaniya o kharaktere dislokatsii porod v yuzhnoi polovinie evropeiski Rossii: Gorniy Zhurnal, v. 3, p. 434-445. (Reprinted in: Klassiki Estestvoznaniya, 1919, and A. P. Karpinskii Sobranie Sochinenii, v. II Akademiya Nauk Soyuza SSR, Izdatelstvo Akademii Nauk SSSR, Moskva, Leningrad, 1939, p. 150-162)

Kilian, C., 1922, "Aperçu général de la structure du Tassili des Ajjer" Comptes Rendus hébdomadaires de l'Académie des Sciences (Paris), v. 175, p. 825-827.

Kilian, C., 1925, Au Hoggar-Mission de 1922: Société d’Éditions Géographiques, Maritimes et Coloniales, Paris, 190 p. +19 plates

Klaproth, J., 1826a, Mémoires Relatifs a l'Asie contenant des Recherches Historiques, Géographiques et Philologiques sur les Peuples de l'Orient, tome second: Librairie Oriental de Dondey-Dupré et Fils, Paris, 432 p.

Klaproth, J., 1826b, Tableaux Historiques de l'Asie Depuis la Monarchie de Cyrus Jusqu'a Nos Jours Accompagnés de Recherches Historiques et Ethnographieques sur cette Partie du Monde: Schubart, Paris; Treuttel et Wurz, Londres; Cotta, Stuttgard, 291 p. + Folio Atlas with 27 double-page coloured maps.

Klaproth, J., 1831, Asia Polyglotta, zweite Auflage: Heideloff \& Campe, Paris, 144 p. and Asia Polyglotta - Sprachatlas, 59 p. of tables +1 coloured map of Asia (dated 1923).

Klaproth, J., 1836, Carte de l'Asie Centrale Dressée d'après les cartes levées par ordre de l'Empereur Khian Loung par les Missionaires de Peking, et d'après un grand nombre de notions extraites de livres chinois par M. Jules Klaproth, 4 sheets, scale 1:2,664,000: L. Berthe, Paris.

Kober, L., 1914, Die Bewegungsrichtung der Alpinen Deckengebirge des Mittelmeers: Dr. A. Petermanns Mitteilungen aus Justus Perthes' Geographischer Anstalt, year 60, May number, p. 250-256+plates 36 and 37.

Kober, L., 1923, Lehrbuch der Geologie für Studierende der Naturwissenschaften, 
Geologen, Montanisten und Techniker: Hölder-Pichler-Tempsky, Vienna, $\mathrm{XI}+425$ p. +2 maps +30 plates.

Kosygin, Yu.A., 1952, Osnovi Tektoniki Neftenosnikh Oblastei: Gostoptekhizdat, Moscow, Leningrad, $510 \mathrm{p}$.

Kosygin, Yu.A., 1969, Tektonika: Izdatelstvo "Nedra”, Moscow, 616 p.

Kreuz, F., 1877, Augit-Andesite des Smrekouz-Gebirges in Südsteiermark: Tschermak's Mineralogische Mittheilungen, 1822, no. 2, p. 205-212.

de Lapparent, A., 1902, Les grands traits du continent asiatique d'après Mr. Ed. Suess: Annales de Géographie, no. 60, 11th year, p. 451-456.

Lelubre, M., 1992, Conrad Kilian, géologue et explorateur saharien: Travaux du Comité Français d’Histoire de la Géologie (COFRHIGEO), 3e série, v. 6, no. 4, p. $75-85$.

Longwell, C.R., 1923, Kober's theory of orogeny: Geological Society of America Bulletin, v. 34, p. 231-241, http://dx.doi.org/10.1130/GSAB-34-231.

Lotze, F., 1937, Zur Methodik der Forschungen über saxonische Tektonik: Geotektonische Forschungen, no. 1, p. 6-27.

Lotze, F., 1938, Das Problem der Saxonischen Faltung: Geotektonische Forschungen, no. 3, p. 73-84.

Lugeon, M., 1901, Les grandes nappes de recouvrement des Alpes du Chablais et de la Suisse: Bulletin de la Société Géologique de France, série 4, v. 1, p. 723-825.

Lugeon, M., 1903, Les nappes de recouvrement de la Tatra et l'origine des Klippes des Carpathes: Bulletin des Laboratoires de Géologie, Géographie Physique, Minéralgie et Paléontologie de l'université de Lausanne (Suisse), No. 4, 51 p (reprint from Bulletin de la Société Vaudouise des Sciences Naturelles, v. 39).

Lyell, C. (Sir), 1857, Supplement to the Fifth Edition of a Manual of Elementary Geology: John Murray, London, [i]+34 p.+1 errata.

Mahler, E., 1887, Biblische Chronologie und Zeitrechnung der Hebräer: Carl Konegen, Wien, XIV+204 p.

Marsh, O.C., 1877, Notice of new Dinosaurian Reptiles from the Jurassic Formation: American Journal of Science, v. 14, p. 514-516, http://dx.doi.org/ 10.2475/ajs.s3-14.84.514.

Martin, G.P.R., 1961, Die Briefe ALBERT OPPELs an FRIEDRICH ROLLE aus den Jahren 1852-1861: Jahresheft des Vereins der Vaterländlicher Naturkunde in Württemberg, 116th Year, p. 124-177.

Matsumoto, T., 1984, Some Ammonites from the Campanian (Upper Cretaceous) of Northern Hokkaido: Palaeontological Society of Japan Special Papers no. 27, $\mathrm{v}+93 \mathrm{p}$.

Milnes, A.G., 1979, Albert Heim's general theory of natural rock deformation (1878): Geology, v. 7, p. 99-103, http://dx.doi.org/10.1130/00917613(1979)7<99:AHGTON>2.0.CO;2.

Molnar, P., and Tapponnier, P., 1975, Cenozoic tectonics of Asia: Effects of a continental collision: Science, v. 189, p. 419-426, http://dx.doi.org/10.1126/science.189.4201.419.

Müller, O.F., 1776, Zoologiæ Danicæ Prodromus, seu Animalium Daniæ et Norvegiæ, Characteres, Nomina, et Synonima Imprimis Popularium: Typis Hallageriis, Havniæ, XXXII+ 274 p.

Murchison, R.I. (Sir), 1857, Address to the Royal Geographical Society of London; delivered at the anniversary meeting on the 25th May, 1857: W. Clowes and Sons, London, $116 \mathrm{p}$.

Murphy, M.A., and Yin, A., 2003, Structural evolution and sequence of thrusting in the Tethyan fold-thrust belt and Indus-Yalu suture zone, southwest Tibet: Geological Society of America Bulletin, v. 115, p. 21-34, http://dx.doi.org/ 10.1130/0016-7606(2003)115<0021:SEASOT>2.0.CO;2.

Mushketov, I.V., 1886, Turkestan-Geologicheskie i Orograficheskie Opisanie po Dannim, Sobrannim vo Vremia i Puteshestvi e 1874 g. po 1880 g., v. 1: M.M. Stasuelevnitscha, S.-Peterburg, $741 \mathrm{p}$.

Mussett, A.E., Dagley, P., and Skelhorn, R.R., 1988, Time and duration of activity in the British Tertiary Igneous Province, in Morton, A.C., and Parson, L.M., eds. Early Tertiary Volcanism and the Opening of the NE Atlantic: Geological Society, London, Special Publications, v. 39, p. 337-348, http://dx.doi.org/ 10.1144/GSL.SP.1988.039.01.29.

Natal'in, B.A., and Şengör, A.M.C., 2005, Late Palaeozoic to Triassic evolution of the Turan and Scythian platforms: The pre-history of the Palaeo-Tethyan closure: Tectonophysics, v. 404, p.175-202, http://dx.doi.org/10.1016/ j.tecto.2005.04.011.

Nathorst, A.G., 1901, Bidrag till nordöstra Grönlands geologi: Geologiska Föreningens i Stockholm Förhandlingar, v. 23, p. 275-306, http://dx.doi.org/10.1080/ 11035890109445867.

Nebelsick, J., Bassi, D., and Lempp, J., 2013, Tracking paleoenvironmental changes in coralline algal-dominated carbonates of the Lower Oligocene Calcareniti di Castelgomberto formation (Monti Berici, Italy): Facies, v. 59, p. 133-148, http://dx.doi.org/10.1007/s10347-012-0349-6.

Neumayr, M., 1885, Die geographische Verbreitung der Juraformation: Denkschriften der kaiserlichen Akademie der Wissenschaften (Wien), mathematisch-naturwissenscaftliche Classe, v. 50, p. 57-86.

von Nordenskiöld, A.E. (Baron), 1882a, Die Umsegelung Asiens und Europas auf der Vega. Mit einem historischen Rückblick auf frühere Reisen längs der Nord küste der Alten Welt, v. 1: F. A. Brockhaus, Leipzig, XIV+477 p. +1 frontispiece (portrait) +10 foldout maps

von Nordenskiöld, A.E. (Baron), 1882b, Die Umsegelung Asiens und Europas auf der Vega. Mit einem historischen Rückblick auf frühere Reisen längs der Nordküste der Alten Welt, v. 2: F. A. Brockhaus, Leipzig, XII+451 p.+1 frontispiece (portrait) +9 maps (some foldout).

Novacek, M.J., 1996, Dinosaurs of the Flaming Cliffs: Anchor Books, New York, ix $+367 \mathrm{p}+8$ plates.

de Novo, P.yF. Chicarro, 1957, Diccionario de Geología y Ciencias Afines, v. II, Paleontología-Estratigrafía, Orogenia y Tectónica: Editorial labor, S.A., Barcelona, Madrid, Buenos Aires, Rio de Janeiro, México, Montevideo, p. 799-1685.

Obrutchev, V., 1959, Elements de Géologie: Editions en Langues Etrangeres, Moscow, $390 \mathrm{p}$.

Okami, K., Masayuki, E., and Koshiva, S., 1994, Compositional changes of the sandstone in relation to the evolution of a mobile belt — an example of the Paleozoic to Mesozoic sandstones of north Japan: Proceedings of the 29th International Geological Congress, Part A, p. 119-134.

Oppel, A., 1858, Die Juraformation Englands, Frankreichs und des Südwest Deutschlands: Ebner \& Seubert, Stuttgart, IV +857 p. +2 foldout tables.

Oppel, A., and Suess, E., 1856, Über die mutmaßlichen Äquivalente der Kössener Schichten in Schwaben: Sitzungsberichte der kaiserlichen Akademie der Wissenschaften in Wien, mathematisch-naturwissenschaftliche Classe, v. 21, p. $535-549+2$ plates.

Orsi, G., Petrazzuoli, S.M., and Wohletz, K., 1999, Mechanical and thermo-fluid behaviour during unrest at the Campi Flegrei caldera (Italy): Journal of Volcanology and Geothermal Research, v. 91, p. 453-470, http://dx.doi.org/ 10.1016/S0377-0273(99)00051-7.

Ostrom, J.H., and McIntosh, J.S., 1966, Marsh's Dinosaurs-The Collections from Como Bluff: Yale University Press, New Haven and London, xiv+388 p.

Owen, R., 1857, Key to the Geology of the Globe: An Essay, designed to show that the present geographical, hydrographical, and geological structures, observed on the Earth's crust, were the result of forces acting according to fixed, demonstrable laws, analogous to those governing the development of organic bodies: Gould and Lincoln, Boston, 256 p +1 coloured folded map +6 folded diagrams.

Oxburgh, E.R., and Turcotte, D.L., 1974, Membrane tectonics and the East African Rift: Earth and Planetary Science Letters, v. 22, p. 133-140, http://dx.doi.org/ 10.1016/0012-821X(74)90073-9.

Partsch, J.[F.M.], 1899, Die Geographische Arbeit des 19. Jahrhunderts: Schlesische Zeitung, nos. 769 and 778 (reprinted as a pamphlet with the same title in 1899 by Wilh[elm]. Gottl[ieb]. ], Korn, Breslau, Korn, 17 p.; also in Waldbaur, H., 1927, editor, Joseph Partsch Aus Fünfzig Jahren Verlorene Schriften: Ferdinand Hirt, Breslau, p. 35-45).

Päßler, U., ed., 2010, Alexander von Humboldt Carl Ritter Briefwechsel ... unter mitarbeit von Eberhard Knobloch: Beiträge zur Alexander-von-HumboldtForschung 32, Akademie Verlag, Berlin, $311 \mathrm{p}$

Piller, W.E., and Harzhauser, M., 2005, The myth of the brackish Sarmatian Sea: Terra Nova, v. 17, p. 450-455, http://dx.doi.org/10.1111/j.13653121.2005.00632.x.

Powell, J.W., 1876, Report on the Geology of the Eastern Portion of the Uinta Mountains and A Region of Country Adjacent Thereto, With Atlas: Department of the Interior. U. S. Geological and Geographical Survey of the Territories. Second Division.-J. W. Powell, Geologist in Charge, Government Printing Office, Washington, VII+218 p.

vom Rath, G., 1871, Ein Ausflug nach Calabrien: Adolph Marcus, Bonn, XII+157 $\mathrm{p}+1$ folded plate

von Richthofen, F. (Freiherr), 1877, China. - Ergebnisse Eigener Reisen und Darauf Gegrundeter Studien. - Erster Band. Einleitender Theil: Dietrich Reimer, Berlin, XLIV +758 p. +2 foldout plates (reprinted in 1971, with a Foreword by Dietmar Henze, by Akademische Druck- und Verlagsanstalt, Graz).

Rogers, W.B., and Rogers, H.D., 1843, On the physical structure of the Appalachian Chain as exemplifying the laws which have regulated the elevation of great mountain chains generally: Reports of the First, Second and Third Meetings of the Association of American Geologists and Naturalists, at Philadelphia in 1840 and 1841, and at Boston in 1842, embracing its Proceedings and Transactions: Gould, Kendall \& Lincoln, Boston, p. 474-531 (This classic paper was later reprinted, with few corrections, in: Rogers, W.B., 1884, A Reprint of Annual Reports and Other Papers on the Geology of the Virginias: D. Appleton and Company, New York, p. 601-642).

Rosenbusch, H., 1898, Elemente der Gesteinslehre: E. Schweizerbart'sche Verlagshandlung (E. Nägele), Stuttgart, VI+545 p. + coloured plates.

Russell, B.[A.W.], 1945[1972], A History of Western Philosophy: A Touchstone Book, Simon \& Schuster, New York, xxiii+895 p.

Ryan, W.B.F., 2009, Decoding the Mediterranean salinity crisis: Sedimentology, v. 56, p. 95-136, http://dx.doi.org/10.1111/j.1365-3091.2008.01031.x. 
Ryan, W.B.F., Hsü, K.J., Nesteroff, V., Pautot, G., Wezel, F., Lort, J.M., Cita, M.B., Mayne, W., Stradner, H., and Dumitricu, P., 1970, Deep Sea Drilling Project, Leg 13: Geotimes, v. 15, no.10, p. 12-15.

Salomon[-Calvi], W., 1897, Über des Alter, Lagerungsform, und Entstehungsart der periadriatischen granitisch-körnigen Massen: Tschermaks Mineralogische und Petrographische Mitteilungen, Neue Folge, v. 17, p. 109-283.

Salomon[-Calvi], W., 1903, Über die Stellung der Randspalten des Eberbacher und des Rheingrabens: Zeitschrift der Deutschen Geologischen Gesellschaft, v. 55, p. $403-418$.

Salomon[-Calvi], W., 1910, Über magmatische Vorgänge: Geologische Rundschau, v. 1, p. 8-18.

Schuchert, C., 1909, Paleogeography of North America: Geological Society of America Bulletin, v. 20, p. 427-606, http://dx.doi.org/10.1130/GSAB-20-427.

Schuchert, C., and LeVene, C.M., 1940, O. C. Marsh—Pioneer in Paleontology: Yale University Press, New Haven, xxi +541 p. +30 plates + frontispiece (portrait)

Sclater, P.L., 1864, The mammals of Madagascar: Quarterly Journal of Science, v. 1, p. 212-219.

Semenov, P., 1858, P. v. Semenow's Erforschungsreisen in Inner-Asien im Jahre 1857, seine Aufnahme des Alpensee's Issyk Kul und anderen Theile der nordwestlichen Russisch- Chinesischen Grenzländer bis zu den Gletschern des Thianschan- Gebirges: Mitteilungen aus Justus Perthes' Geographischer Anstalt uber Wichtige Neue Erforschungen aus dem Gesammtgebiete der Geographie von Dr. Petermann, year 1858, no.9, p. 351-369 +plate 16

Sengör, A.M.C., 1976, Collision of irregular continental margins: Implications for foreland deformation of Alpine-type orogens: Geology, v. 4, p. 779-782, http://dx.doi.org/10.1130/0091-7613(1976)4<779:COICMI>2.0.CO;2.

Şengör, A.M.C., 1977, New historical data on crustal subduction: The Journal of Geology, v. 85, p. 631-634, http://dx.doi.org/10.1086/628343.

Şengör, A.M.C., 1982, Eduard Suess' relations to the pre-1950 schools of thought in global tectonics: Geologische Rundschau, v. 71, p. 381-420, http://dx.doi.org/10.1007/BF01822372.

Şengör, A.M.C., 1983, Gondwana and "Gondwanaland”: A discussion: Geologische Rundschau, v. 72, p. 397-400, http://dx.doi.org/10.1007/BF01765917.

Şengör, A.M.C., 1990, Lithotectonic terranes and the plate tectonic theory of orogeny: a critique of the principles of terrane analysis, in Wiley, T.J., Howell, D.G., and Wong, F.L., eds., Terrane Analysis of China and the Pacific Rim: Houston, Circum-Pacific Council for Energy and Mineral Resources, Earth Science Series, v. 13 , p. $9-44$

Sengör, A.M.C., 1991, Difference between Gondwana and Gondwana-Land: Geology, v. 19, p. 287-288, http://dx.doi.org/10.1130/0091-7613(1991)019 $<0287$ :L $>2.3 . \mathrm{CO} ; 2$

Şengör, A.M.C., 1998, Die Tethys: vor hundert Jahren und heute: Mitteilungen der Österreichischen Geologischen Gesellschaft, v. 89, p. 5-176.

Şengör, A.M.C., 2003, The repeated rediscovery of mélanges and its implications for the possibility and the role of objective evidence in the scientific enterprise: $i n$ Dilek, Y., and Newcomb, S., eds., Ophiolite Concept and the Evolution of Geological Thought: Geological Society of America Special Papers, v. 373, p $385-445+1$ foldout plate in the back of the volume.

Şengör, A.M.C., 2009, Der tektonisch einseitige Schub von Eduard Sueß: mechanischer Unsinn oder geologische Wahrheit? Jahrbuch der Geologischen Bundesanstalt Wien, v. 149, Nr 2+3 (Cernajsek-Festschrift), p. 391-410.

Şengör, A.M.C., 2013, The Pyrenean Hercynian keirogen and the Cantabrian Orocline as genetically coupled structures: Journal of Geodynamics, v. 65 (Ali Koçyiğit Festschrift), p. 3-21.

Sengör, A.M.C., 2014, Eduard Suess and global tectonics: an illustrated 'short guide' Austrian Journal of Earth Sciences (Suess special issue), v. 107, p. 6-82.

Şengör, A.M.C., in press, Die Korrespondenz zwischen Albert Oppel und Friedrich Rolle als Schlüssel zu Eduard Sueß’ Bedeutung bei der Korrelation der Kössener Schichten: Jahrbuch der Geologischen Bundesanstalt, v. 154.

Şengör, A.M.C., and Atayman, S., 2009, The Permian Extinction and the Tethys: An Exercise in Global Geology: Geological Society of America Special Papers, v. $448, \mathrm{x}+96 \mathrm{p}$

Şengör, A.M.C., and Dewey, J.F., 1990, Terranology: Vice or Virtue? Philosophical Transactions of the Royal Society of London, v. 331, p. 457-477, http://dx.doi.org/10.1098/rsta.1990.0083.

Şengör, A.M.C., and Natal'in, B.A., 1996, Palaeotectonics of Asia: Fragments of a Synthesis, in, Yin, A., and Harrison, M., eds., The Tectonic Evolution of Asia, Rubey Colloquium, Cambridge University Press, Cambridge, p. 486-640.

Şengör, A.M.C., and Natal'in, B.A., 2007, Eduard Suess and the Altaids: What is in a name?, in Seltmann, R., Borisenko, A., and Fedoseev, G., eds., Magmatism and Metallogeny of the Altai and Adjacent Large Igneous Provinces with an Introductory Essay on the Altaids, IAGOD Guidebook Series 16. CERCAMS NHM, London, p. 185-294.

Sengör, A.M.C., and Okuroğullar1, A.H., 1991, The role of accretionary wedges in the growth of continents: Asiatic examples from Argand to plate tectonics: Eclogae Geologicae Helvetiae, v. 84, p. 535-597.
Şengör, A.M.C., Altıner, D., Cin, A., Ustaömer, T., and Hsü, K.J., 1988, Origin and assembly of the Tethyside orogenic collage at the expense of Gondwana-Land, in Audley-Charles, M.G. and Hallam, A., eds., Gondwana and Tethys: Geological Society, London, Special Publications, v. 37, p. 119-181, http://dx.doi.org/10.1144/GSL.SP.1988.037.01.09.

Şengör, A.M.C., Natal'in, B.A., and Burtman, V.S., 1993, Evolution of the Altaid tectonic collage and Palaeozoic crustal growth in Eurasia: Nature, v. 364, p. 299-307, http://dx.doi.org/10.1038/364299a0.

Sengör, A.M.C., Natal'in, B.A. Sunal, G., and van der Voo, R., 2014a, A new look at the Altaids: a superorogenic complex in northern and central Asia as a factory of continental crust. Part 1: geological data compilation (exclusive of palaeomagnetic observations): Austrian Journal of Earth Sciences (Suess special issue), v. 107, p. 169-232.

Şengör, A.M.C., Natal'in, B.A., van der Voo, R., and Sunal, G., 2014b, A new look at the Altaids: a superoroganic complex in northern and central Asia as a factory of continental crust. Part II: palaeomagnetic data, reconstructions, crustal growth and global sea-level: Austrian Journal of Earth sciences (Suess special issue), v. 107/2, p. 131-181

Smoluchowski, S.M., 1909, Some remarks on the mechanics of overthrusts: Geological Magazine, decade 5, v. 6, p. 204-205.

Snider, A., 1858, Le Création et ses Mystères Dévoilés-Ouvrage où l'on expose clairement la Nature de tous les Etres les Eléments dont ils sont composés et leurs rapports avec le globe et les astres la Nature et la Situation du Feu du Soleil l'Origine de l'Amérique et des ses Habitants primitifs la Formation Forcée de nouvelles Planètes l'Origine des Langues et les Causes de la Variété des Physiognomies le Compte Courant de l'Homme avec la Terre, etc.: A. Franck and E. Dentu, Paris, $487 \mathrm{p}$.

Sollas, W.J., 1909, Address delivered at the Anniversary Meeting of the Geological Society of London: Proceedings of the Geological Society of London, v. 65, p. i-cxxii.

Solomon, S.C., 1987, Secular cooling of the Earth as a source of intraplate stress: Earth and Planetary Science Letters, v. 83, p. 153-158, http://dx.doi.org/ 10.1016/0012-821X(87)90058-6.

Sougy, J., 1962, West African fold belt: Geological Society of America Bulletin, v. 73, p. 871-876, http://dx.doi.org/10.1130/0016-7606(1962)73[871:WAFB] 2.0.CO;2.

Steinmann, G., 1905, Geologische Beobachtungen in den Alpen II. Die Schardt'sche Überfaltungstheorie und die geologische Bedeutung der Tiefseeabsätze und der ophiolitischen Massengesteine: Berichten der Naturforschenden Gesellschaft zu Freiburg i. B., v. 16, p. 18-67.

Steinmann, G., 1910, Gebirgsbildung und Massengesteine in der Kordillere Südamerikas: Geologische Rundschau, v. 1, p. 13-35, http://dx.doi.org/10.1007/ BF01792940.

Steinmann, G., 1927, Die ophiolitischen Zonen in den Mediterranen Kettengebirgen: XIVe Congrés Géologique International (1926, Espagne), 4. Fscl., (Graficas Reunida S. A.), Madrid, p. 637-667. (for an English translation, see: Steinmann, G., 2003, Die ophiolitischen Zonen in den Mediterranen Kettengebirgen (The ophiolitic zones in the Mediterranean mountain chains) translated by Daniel Bernoulli and Gerald M. Friedman, in Dilek, Y., and Newcomb, S., eds., Ophiolite Concept and the Evolution of Geological Thought: Geological Society of America Special Papers, v. 373, p. 77-91).

Stevens, C.H., and Stone, P., 2005, Interpretation of the Last Chance thrust, Death Valley region, California, as an Early Permian décollement in a previously undeformed shale basin: Earth-Science Reviews, v. 73 (Lauren A. Wright volume), p. 79-101, http://dx.doi.org/10.1016/j.earscirev.2005.04.005.

Stille, H., 1922, Die Schrumpfung der Erde-Festrede gehalten zur Jahresfeier der Georg August-Universität zu Göttingen am 5. Juli 1922: Gebrüder Borntraeger, Berlin, $37 \mathrm{p}$.

Stille, H., 1924, Grundfragen der Vergleichenden Tektonik: Gebrüder Borntraeger, Berlin, VII +[]$+443 \mathrm{p}$

Stille, H., 1928, Der Stammbaum der Gebirge und Vorländer, XIVe Congrés Géologique International (1926, Espagne), 4e Fascicule, 6e Partie, Sujet XI (Divers): Graficas Reunida S.A., Madrid, p. 1749-1770.

Stille, H., 1940a, Einführung in den Bau Amerikas: Gebrüder Borntraeger, Berlin, $\mathrm{XX}+717 \mathrm{p}$.

Stille, H., 1940b, Zur Frage der Herkunft der Magmen: Abhandlungen der Preußischen Akademie der Wissenschaften, Jg. 1939, Mathematisch-naturwissenschaftliche Klasse, Nr. 19, p. 3-31

Stille, H., 1950, Der "subsequente" Magmatismus: Miscellanea Academica Berolinensisa, Akademie-Verlag, Berlin, 25 p.

Stille, H., 1953, Der Geotektonische Werdegang der Karpaten: Beihefte zum Geologischen Jahrbuch, v. 8, 239 p. 1 folded geological map.

Stille, H., 1954, Unterschiebungs-Palingenese: Congrès Géologique International Comptes rendus de la dix-neuvième Session Alger 1952, Section XV La Paléovolcanologie es ses Rapports avec la Tectonique, fascicule XVII, Alger, p. $127-137$. 
Stille, H., 1955, Recent deformations of the earth's crust in the light of those of earlier epochs, in Poldervaart, A. ed., The Crust of the Earth: Geological Society of America Special Paper, v. 62, p. 171-192.

Stille, H., 1960, Die zirkumpazifische Serotektonik als derzeitiger Schlußakt im Entwicklungsgange des Zirkumfazifikums: Abhandlungen der Deutschen Akademie der Wissenschfaften, Klasse III, Heft I (Festschrift zum 70. Geburtstag von Ernst Kraus), p. 121-146.

Stover, C.W., and Coffman, J.L., 1993, Seismicity of the United States, 1568-1989 (Revised): U.S. Geological Survey Professional Paper 1527, v+418 p.

Stroh, A.H., 1910, The sources of Emanuel Swedenborg's early philosophy of Nature: Emanuel Swedenborg as a Scientist-Miscellaneous Contributions: Aftonbladets Tryckeri, Stockholm, p. 83-112.

Stroh, A.H., and Ekelöf, G., 1910, An Abridged Chronological List of the Works of Emanuel Swedenborg including manuscripts, Original Editions and Translations Prior to 1772: Almqvist \&Wiksells Boktryckeri-A.-E., Uppsala and Stockholm, $54 \mathrm{p}$.

Suess, E., 1851, Ueber böhmische Graptolithen: Naturwissenschaftliche Abhandlungen gesammelt durch Subskription herausgegeben von Wilhelm Haidinger, v. 4, p. 87-134 + plates 7-9.

Suess, E., 1854, Über die Brachiopoden der Kössener Schichten: Denkschriften der mathematisch-naturwissenschaftlichen Classe der kaiserlichen Akademie der Wissenschaften [in Vienna], v. 7, p. 29-65 + plates I-IV.

Suess, E., 1855, Notice sur l'appareil brachial des Thécidées; ... traduit de l'Allemand par M. le Comte F. A. de Marshall and Observations sur le Méme Sujet; par Eugène Deslongchamps: Extrait du Xe volume des Mémoires de la Société Linnéenne de Normandie: A. Hardel, Caën, 22 SS.+Plates IV (by mistake printed as $\mathrm{Pl}$. III) and V.

Suess, E., 1857, Das Dachsteingebirge von Hallstätter Salzberg bis Schladming im Ennsthale, in von Hauer, F. (Ritter), Ein geologischer Durchschnitt der Alpen von Passau bis Duino: Sitzungsberichte der mathematisch-naturwissenchaftlichen Classe der kaiserlichen Akademie der Wissenschaften [in Vienna], v. 25, p. 300-313.

Suess, E., 1859, Über die Wohnsitze der Brachiopoden-I. Abschnitt: Sitzungsberichte der kaiserlichen Akademie der Wissenschaften, mathematisch-naturwissenschaftliche Classe, v. 37, p. 185-248

Suess, E., 1860a, Über die Wohnsitze der Brachiopoden-II. Abschnitt. Die Wohnsitze der fossilen Brachiopoden: Sitzungsberichte der kaiserlichen Akademie der Wissenschaften, mathematisch-naturwissenschaftliche Classe, v. 39, p. 151-206.

Suess, E., 1860b, Über die Spuren eingentümlicher Eruptions- Erscheinungen am Dachstein-Gebirge: Sitzungsberichte der mathematisch-naturwissenchaftlichen Classe der kaiserlichen Akademie der Wissenschaften [in Vienna], v. 40, p. 428-442.

Suess, E., 1867, Note sur le Gisement des Térébratules du groupe de Diphya dans l'Empire d'Autriche, in Pictet, F.-J., Mélanges Paléontologiques, troisième livraison: Ramboz et Schuchardt, Genève, p. 185-201+Plate 35.

Suess, E., 1868a, Bemerkungen über die Lagerung des Salzgebirges bei Wieliczka: Sitzungsberiche der kaiserlichen Akademie der Wissenschaften-mathematischnaturwissenschaftliche Klasse, v. 58, p. 541-547.

Suess, E., 1868b, Ueber die Eruptivgesteine des Smrekouz-Gebirges in Steiermark: Verhandlungen der Kaiserlichen und Königlichen Geologischen Reichsanstalt, 1868 , no. 2, p. $32-36$.

Suess, E., 1872, Über den Bau der italienischen Halbinsel: Sitzungsberichte der kaiserlichen Akademie der Wissenschaften, mathematisch-naturwissenschaftliche Classe, v. 65, Part I, no. 3, p. 217-221.

Suess, E., 1873, Ueber den Aufbau der mitteleuropäischen Hochgebirge: Anzeiger der Akademie der Wissenschaften [in Wien], für die Woche von 24. Juli 1873, p. $130-131$.

Suess, E., 1875, Die Entstehung der Alpen: W. Braumüller, Vienna, IV+168 p.

Suess, E., 1883, Das Antlitz der Erde, v. Ia (Erste Abtheilung): F. Tempsky, Prague and G. Freytag, Leipzig, $310 \mathrm{p}$

Suess, E., 1885, Das Antlitz der Erde, v. Ib: F. Tempsky, Prague and G. Freytag, Leipzig, IV+311-778+[1] p.

Suess E., 1886, Über unterbrochene Gebirgsfaltung: Sitzungsberiche der kaiserlichen Akademie der Wissenschaften in Wien, mathematisch-naturwissenschaftliche Klasse, v. 94, part I, p. 111-117.

Suess, E., 1888, Das Antlitz der Erde, v. II: F. Tempsky, Prague and Vienna, and G. Freytag, Leipzig, IV + 704 p.

Suess, E., 1890, Über die Struktur Europas: Vorträge des Vereins zur Verbreitung Naturwissenschaftlicher Kenntnisse in Wien, year 30, no. 1, p. 1-21.

Suess, E., 1891, Beiträge zur geologischen Kenntniss des östlichen Afrika, Theil IV, Die Brüche des östlichen Afrika: Denkschriften der kaiserlichen Akademie der Wissenschaften in Wien, v. 58, p. 111-140, 1 foldout section und +3 plates of photomicrographs.

Suess, E., 1893, Are great ocean depths permanent?: Natural Science, v. 2, p. 180-187

Suess, E., 1897, La Face de la Terre (Das Antlitz der Erde), traduit de l'Allemand, avec l'autorisation de l'auteur et annoté sous la direction de Emm. De Margerie, v. I Armand Colin, Paris, XV+835 p. +2 coloured plates.

Suess, E., 1898, Über die Assymetrie der nördlichen Halbkugel: Sitzungsberichten der kaiserlichen Akademie der Wissenschaften zu Wien, Mathematisch-naturwissenschaftliche Classe, Abt. I, v. 107, p. 89-192. (An English translation of this paper was appended to the presidential address to the Geological Society of America by Benjamin Kendall Emerson, the translation having been undertaken by the president himself).

Suess, E., 1901, Das Antlitz der Erde, v. III/1 (Dritter Band. Erste Hälfte): F. Tempsky, Prague and Vienna, and G. Freytag, Leipzig, IV + 508 p.

Suess, E., 1902, Abschieds-Vorlesung des Professors Eduard Suess bei seinem Rücktritte vom Lehramte gehalten am 13. Juli 1901 im Geologischen Hörsaale der Wiener Universität: Beiträge zur Paläontologie und Geologie ÖsterreichUngarns und des Orients, v. 14, no. 1, p. 1-8 (There is an English translation of this lecture: Suess, E., 1904, Farewell lecture by Professor Eduard Suess on resigning his professorship (translation from German by Charles Schuchert): Journal of Geology, v. 12, p. 264-275), http://dx.doi.org/10.1086/621149).

Suess, E., 1904a, The Face of the Earth (Das Antlitz der Erde), translated by Hertha B.C. Sollas under the direction of W.J. Sollas, v. I: Clarendon Press, Oxford, xii +604 p.

Suess, E., 1904b, Sur la nature des charriages: Comptes Rendus hébdomadaire de L'Académie de Sciences, Paris, v. 139, p. 714-717.

Suess, E., 1904c, Farewell lecture by Professor Edward Suess on resigning his professorship, translated by Charles Schuchert: The Journal of Geology, v. 12, p. 264-275, http://dx.doi.org/10.1086/621149.

Suess, E., 1905, Über das Inntal bei Nauders: Sitzungsberichte der kaiserlichen Akademie der Wissenschaften in Wien: Mathematisch-naturwissenschaftliche Klasse, v. 114, part 1, p. 699-735.

Suess, E., 1906, The Face of the Earth (Das Antlitz der Erde), v. II: Clarendon Press, Oxford, vi +566 p.

Suess, E., 1908, The Face of the Earth (Das Antlitz der Erde), v. III: Clarendon Press, Oxford, viii +400 p.

Suess, E., 1909a, Das Antlitz der Erde, v. III/2 (Dritter Band. Zweite Hälfte. Schlus des Gesamtwerkes): F. Tempsky, Vienna and G. Freytag, Leipzig, IV +789 p.

Suess, E., 1909b, The Face of the Earth (Das Antlitz der Erde), v. IV: Clarendon Press, Oxford, viii +673 p.

Suess, E., 1909c, Das Leben: Mitteilungen der Geologischen Gesellschaft, Vienna, v. 2, p. 148-161.

Suess, 1910a, John Dee. Die Tragödie eines entgleisten Naturforschers: Österreichische Rundschau, v. 23 (April-Juni 1910), p. 102-114.

Suess, E., 1910b, Zu "John Dee": Österreichische Rundschau, v. 23 (April-Juni 1910), p. 265-267.

Suess, E., 1911a, Synthesis of the paleogeography of North America: American Journal of Science, 4th Series, v. 31, p. 101-108.

Suess, E., 1911b, La Face de la Terre (Das Antlitz der Erde), traduit de l'Allemand, avec l'autorisation de l'auteur et annoté sous la direction de Emm. De Margerie, tome III (1 $1^{\text {re }}$ partie): Armand Colin, Paris, XI+[] p. + p. 531-956 p. + plates 4-7

Suess, E., 1911c, Über die Donau: Vortag gehalten in der ausserordentlichen Festversammlung der kaiserlichen Akademie der Wissenschaften am 9. März 1911, Alfred Hölder, Wien, 27 p.

Suess, E., 1912, La Face de la Terre (Das Antlitz der Erde), traduit de l'Allemand, avec l'autorisation de l'auteur et annoté sous la direction de Emm. De Margerie, tome III ( $2^{\mathrm{e}}$ partie): Armand Colin, Paris, XI+530 p. +3 plates.

Suess, E., 1913a, La Face de la Terre (Das Antlitz der Erde), traduit de l'Allemand, avec l'autorisation de l'auteur et annoté sous la direction de Emm. De Margerie, tome III ( $3^{e}$ partie $\{$ Fin $\left.\}\right)$ : Armand Colin, Paris, $X+[1]+$ p. $956-1360+1$ coloured foldout map.

Suess, E., 1913b, Über die Zerlegung der gebirgsbildenden Kraft: Mitteilungen der Geologischen Gesellschaft in Wien, v. I, p. 13-60+2 photographic plates.

Suess, E., 1916, Erinnerungen: S. Hirzel, Leipzig IX+451 p.

Suess, E., 1918, La Face de la Terre (Das Antlitz der Erde), traduit de l'Allemand, avec l'autorisation de l'auteur et annoté sous la direction de Emm. De Margerie, tome III (4 $4^{e}$ partie $\{$ Fin $\left.\}\right)$ : Armand Colin, Paris, XV+T p. +p. 1361-1724+ 2 coloured maps +3 plates.

Suess, E., 1924, The Face of the Earth (Das Antlitz der Erde), v. V Indexes and Maps: Clarendon Press, Oxford, xvi+170 p.+XVIII plates.

Suess, E., 1928, La Faz de la Tierra (Das Antlitz der Erde), versión española de Pedro de Novo y F. Chicarro: Ramona Velasco, Madrid, v. 3, XLIV+ 661 p.+8 plates.

Suess, F.E., 1981, Das Lebenswerk von Eduard SUESS-Dargestellt von seinem Sohn F. E. Suess anläßlich des hundertsten Geburtstages: Mitteilungen der österreichischen geologischen Gesellschaft, v. 74/75, p. 1-6.

Supan, A., 1899. Die Bodenformen des Weltmeeres, Mitteilungen aus Justus Perthes' Geographischer Anstalt uber Wichtige Neue Erforschungen aus dem Gesammtgebiete der Geographie von Dr. Petermann, year 1899 no. 45, p. 177-188. 
Taylor, F.B., 1910, Bearing of the Tertiary mountain belt on the origin of the earth's plan: Geological Society of America Bulletin, v. 21, p. 179-226, http://dx.doi.org/10.1130/GSAB-21-179.

Termier, P., 1903, Les nappes des Alpes Orientales et la Synthèse des Alpes: Bulletin de la Société Géologique de France, série 4, v. 3, p. 711-765 p.

Termier, P., 1920, Les océans à travers les âges: Bulletin de l'Institut Océanographique, no. 365, 30 Mars 1920, 20 p.

Tietze, E., 1917, Einige Seiten über Eduard Suess-Ein Beitrag zur Geschichte der Geologie: Jahrbuch der königlich- und kaiserlichen Geologischen Reichsanstalt, v. 66, p. $333-556$.

Tollmann, A., 1963, Die Ostalpensynthese: Franz Deuticke, Vienna, [II] +256 p.+11 folded plates in a separate cover.

Tollmann, A., 1977, Geologie von Österreich: Franz Deuticke, Vienna, v. 1, XVI+766 p.

Trümpy, R., 1960, Paleotectonic evolution of the Central and Western Alps: Geological Society of America Bulletin, v. 71, p. 843-907, http://dx.doi.org/ 10.1130/0016-7606(1960)71[843:PEOTCA]2.0.CO;2.

Trümpy, R., 1976, Du Pelèrin aux Pyrenées: Eclogae Geologicae Helvetiae, v. 69, p. 249-264.

Turcotte, D.L., 1973, Membrane Tectonics: Geophysical Journal of the Royal Astronomical Society, v. 36, p. 33-42.

Turcotte, D.L., and Oxburgh, E.R., 1973, Mid-plate tectonics: Nature, v. 244, p. 337-339, http://dx.doi.org/10.1038/244337a0.

Uhlig, V., 1903, Bau und Bild der Karpathen: in Diener, C., Hoernes, R., Suess, F. E. and Uhlig, V., Bau und Bild Österreichs mit einem Vorworte von Eduard Suess: F. Tempsky, Vienna and G. Freytag, Leipzig, p. 649-911+ one coloured foldout map.

Uhlig, V., 1907a, Über die Tektonik der Karpathen: Sitzungsberichte der kaiserlichen Akademie der Wissenschaften, mathematisch-naturwissenschaftliche Klasse, v. 116, part I, p. 871-982+1 plate of sections +1 map.

Uhlig, V., 1907b, Der sogenannte grosse ostafrikanische Graben zwischen Magad (Natron-See) und Lawa ja Mwerie (Manjara-See): Geographische Zeitschrift, v 13, p. 478-505.

Uhlig, V., 1909, Die Ostafrikanische Bruchstufe und die angrenzenden Gebiete zwischen den seen Magad und Lawa ja Mweri, sowie dem West-Fuß des Meru: Mitteilungen aus den Deutschen Schutzgebieten: Ergänzungsheft, v. 2, 63 p.

Ulmishek, G., 2003, Petroleum geology and resources of the West Siberian Basin, Russia: U.S. Geological Survey Bulletin 2201-G, IV+49 p.

Uwatoko, K., and Ohtatsume, K.-i., 1933, The Upper Cretaceous oil bearing sedimentary rocks of Hokkaido, Japan: Journal of the Faculty of Science, Hokkaido Imperial University, series 4, Geology and Mineralogy, v. 2, p. 133-162.

Walcott, C.D., 1895a, Lower Cambrian rocks in Eastern California: American Journal of Science, 3rd series, v. 49, p. 141-144.

Walcott, C.D., 1895b, The Appalachian type of folding in the White Mountain Range of Inyo County, California: American Journal of Science, 3rd series, v. 49, p. 169-174.

Walravens, H., 1999, Julius Klaproth (1783-1835) Briefe und Dokumente: Orientalistik, Bibliographien und Dokumenten, v. 4, Harrassowitz, Wiesbaden, 235 p.

van Waterschoot van der Gracht, W.A.J.M., 1938, Lateral movements on the Alpine foreland of northwestern Europe: Proceedings of the Koninklijke Nederlandsche Akademie van Wetenschappen te Amsterdam, v. 41, no. 3, p. 195-214

White, B.G., 2000, Coeur d'Alene mining district: product of preconcentrated source deposits and tectonism within the Lewis and Clark line, in Roberts, S., and Winston, D., eds., Geologic Field Trips, Western Montana and Adjacent Areas: Rocky Mountain Section of the Geological Society of America, University of Montana, p. 95-101.

Wilckens, O., 1910, Die Alpen im Schlußbande von Suess' Antlitz der Erde: Geologische Rundschau, v. 1, p. 29-34, http://dx.doi.org/10.1007/BF01801130.

Wilson, J.T., 1965, A new class of faults and their bearing on continental drift: Nature, v. 207, p. 343-347, http://dx.doi.org/10.1038/207343a0.

Wilson, J.T., 1982, Early days in university geophysics: Annual Review of Earth and Planetary Sciences, v. 10 p. 1-14, http://dx.doi.org/10.1146/annurev.ea. 10.050182 .000245

Woodring, W.P., 1970, Geology and paleontology of canal zone and adjoing parts of Panama: Description of Tertiary mollusks (gastropods: Eulimidae, Marginellidae to Helminthoglyptidae): United States Geological Survey Professional Paper 306(D), p. 299-452.

von Zittel, K.A., 1899, Geschichte der Geologie und Paläontologie bis Ende des 19. Jahrhunderts: R. Oldenbourg, München, XI+868 p.

Received October 2014

Accepted as revised December 2014 